Sergio Henrique Bonachela

\title{
TUTELA JURISDICIONAL DOS \\ INTERESSES INDIVIDUAIS HOMOGÊNEOS
}

Dissertação apresentada à Faculdade de Direito da Universidade de São Paulo para a habilitação para o título de Mestre em Direito.

Área de Concentração: Direito Processual

Orientador: Prof. Dr. Rodolfo de Camargo Mancuso 


\section{DEDICATÓRIA}

Dedico este trabalho a todos os professores que tiveram a generosidade de transmitir um pouco do seu conhecimento com o sincero propósito de que eu me tornasse uma pessoa melhor. Todo o meu esforço é para não decepcioná-los. 


\section{AGRADECIMENTOS}

Ao meu orientador, pela cortesia e dedicação com as quais auxiliou o desenvolvimento deste trabalho.

À minha família, pelo incentivo e apoio para que eu pudesse alcançar mais esse objetivo.

À minha esposa Claudia, pela paciência em tolerar minha ausência. 


\section{RESUMO}

O objetivo deste estudo é investigar a tutela coletiva dos interesses individuais homogêneos com a finalidade de mostrar como se comportam em juízo, como se adaptam aos instrumentos processuais existentes e quando a sua defesa judicial é possível, conveniente e necessária. O estudo começa da pesquisa sobre as características dos próprios interesses, passa pela crítica dos atributos da sua tutela coletiva e procura aplicar os resultados dessa investigação aos problemas antigos e atuais que mais têm dificultado a sua proteção jurisdicional. O trabalho foi delimitado pela perspectiva da coletividade, titular dos interesses individuais homogêneos, colocada no polo ativo do processo coletivo, no procedimento comum. A metodologia de trabalho utilizada constituiu-se de leitura, análise, resumo, interpretação, sistematização e compilação de textos, livros e revistas periódicas dedicados ao tema, além de relatórios e documentos pertinentes aos assuntos tratados, incluindo os disponíveis na rede mundial de computadores (Internet).

Os interesses individuais homogêneos, sem perder sua essência individual, possuem uma dimensão coletiva que lhes aproxima dos demais interesses coletivos, que não se adaptam com facilidade aos instrumentos processuais criados para a jurisdição singular. A sua tutela coletiva é possível quando existir um núcleo homogêneo, sua principal característica; útil quando a lesão causada a esses interesses puder ser demonstrada sem questionar a própria existência desse núcleo; conveniente quando a sua relevância social e as dificuldades de acesso à justiça assim exigirem. Alguns dos principais problemas enfrentados pela tutela coletiva de interesses individuais homogêneos não têm solução com base na legislação vigente, nem são contemplados nas propostas de alteração atualmente em discussão. A legitimação do Ministério Público para a propositura de ação coletiva para defesa de interesses individuais homogêneos decorre de expressa previsão legal dessa legitimidade, da indisponibilidade do interesse ou da sua relevância social, não se estendendo à execução em favor de particulares. É possível o controle de constitucionalidade em ação coletiva, desde que com efeitos concretos e sujeito a recurso extraordinário. 


\section{SUBSTRACT}

The purpose of this study is to investigate the class action for damages in order to show how they behave in court, as they adapt to existing procedural tools and when their legal defense is possible, desirable and necessary. It departs from research on the characteristics of the interests, is critical of the attributes of its class treatment and seeks to apply the results of that research to ancient and current problems that have hampered its most court protection. The work was limited by the plaintiff class action and by the common procedure. The methodology used was the work of reading, analysis, summary, interpretation, and systematic compilation of texts, books, periodicals and magazines devoted to the subject, in addition to reports and documents relevant to the matters discussed, including those available on the World Wide Web (Internet) .

Individual interests commons to a class, without losing its essence individual, have a collective dimension to them approaching other collective interests, which do not adapt easily to the procedural tools created for the individual jurisdiction. Their collective protection by class action is possible when there is a homogenous core, its main feature; is useful when the damage caused to those interests can be demonstrated without question the very existence of that core; and is convenient when its social relevance and the difficulties of access to justice thus require. Some of the main problems faced by the class action for damages do not have solution based on current brazilian legislation, or are contemplated in the draft amendment under discussion. The legitimacy of the public attorney for the commencement of class action for damages follows express provision of legal authorization to this effect, the unavailability of interest or of its social relevance, and it is not extending the implementation in favor of individuals. It is possible the judicial review in class action, provided with practical effects and subject to special appeal. 


\section{SUMÁRIO}

Considerações preliminares.

Capítulo 1 - As características dos interesses individuais homogêneos........................ 11

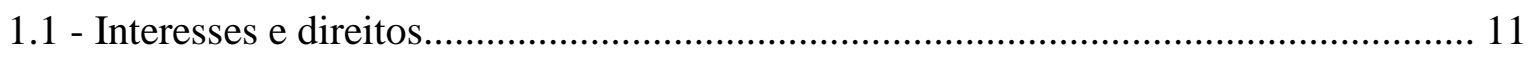

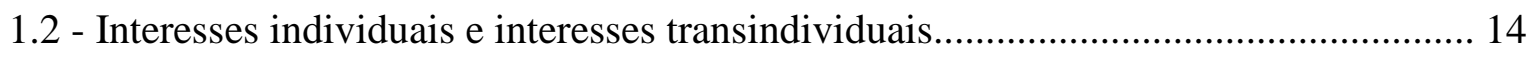

1.3 - Interesses essencialmente coletivos e interesses episodicamente coletivos................ 15

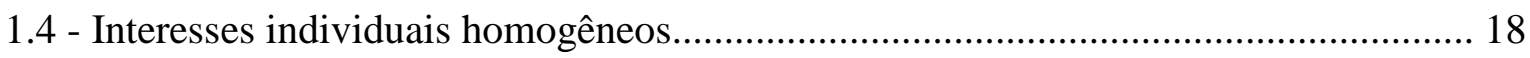

1.5 - A dimensão coletiva dos interesses individuais homogêneos..................................... 21

Capítulo 2 - As dificuldades dos interesses individuais homogêneos.............................. 26

2.1 - Sociedade moderna e conflitos de massa.............................................................. 26

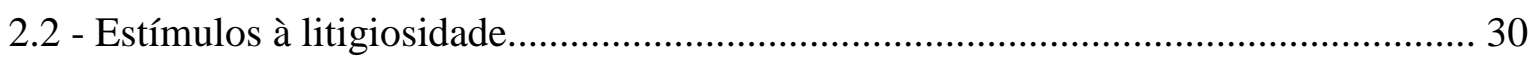

2.3 - Métodos alternativos de solução de controvérsias................................................... 33

2.4 - Jurisdição singular e Poder Judiciário.................................................................. 35

2.4.1 - A cultura jurídico-processual individualista............................................... 35

2.4.2 - A estrutura judiciária e o acúmulo de processos............................................ 40

Capítulo 3 - As características da tutela jurisdicional dos interesses individuais homogêneos......................................................................................................................................... 45

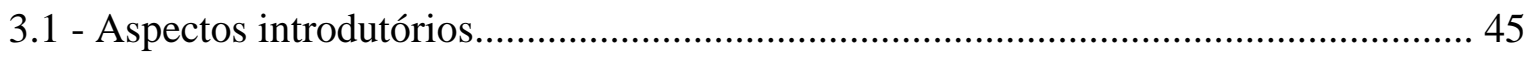

3.2 - Possibilidade da tutela coletiva de interesses individuais........................................ 46

3.3 - Utilidade da tutela coletiva de interesses individuais............................................ 53

3.4 - Conveniência da tutela coletiva de interesses individuais homogêneos...................... 60 
3.4.1 - Considerações iniciais 60

3.4.2 - Relevância do bem jurídico tutelado e da sua violação 62

3.4.3 - Remoção de obstáculos ao acesso à justiça. 65

3.4.4 - Critérios para aferição da conveniência 68

Capítulo 4 - As dificuldades da tutela jurisdicional dos interesses individuais

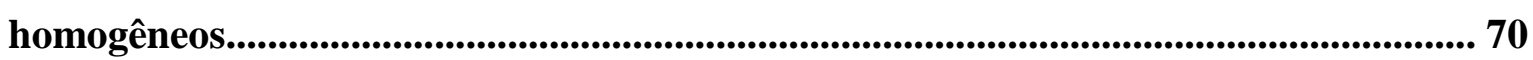

4.1 - Do litisconsórcio à tutela coletiva de interesses individuais homogêneos.................. 70

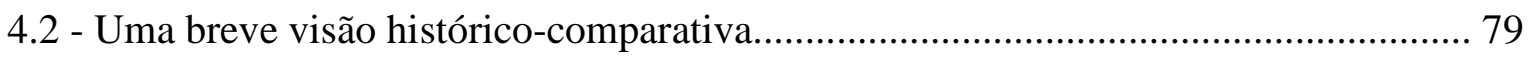

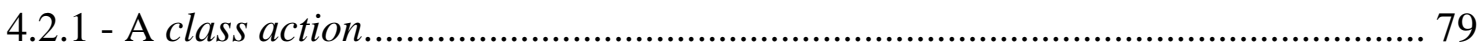

4.2.2 - A Lei da Ação Civil Pública e o Código de Defesa do Consumidor................... 96

4.3 - Problemas antigos e a legislação vigente................................................................. 101

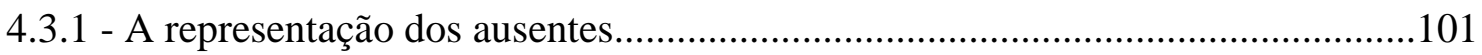

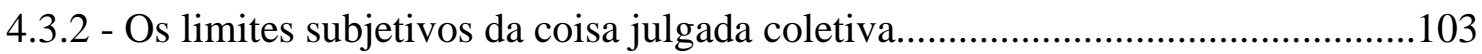

4.3.3 - A resistência do Poder Executivo à tutela coletiva...........................................106

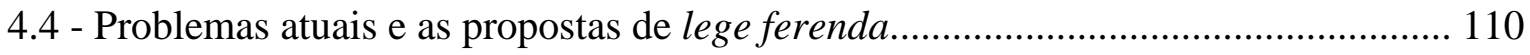

4.4.1 - As propostas de Código de Processo Coletivo e suas inovações...................... 110

4.4.2 - Os problemas atuais e as soluções propostas.................................................... 120

Capítulo 5 - As incertezas na tutela jurisdicional dos interesses individuais

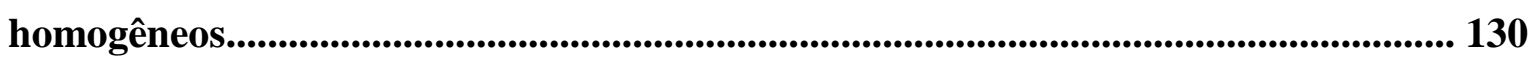

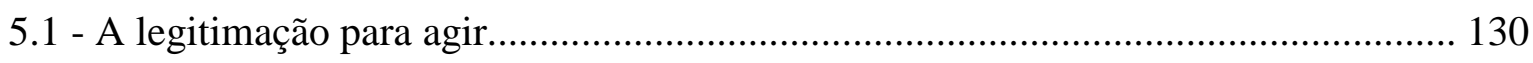

5.1 .1 - Aspectos polêmicos ............................................................................ 130

5.1.2 - Estudo de caso: indisponibilidade e legitimação do Ministério Público.......... 138

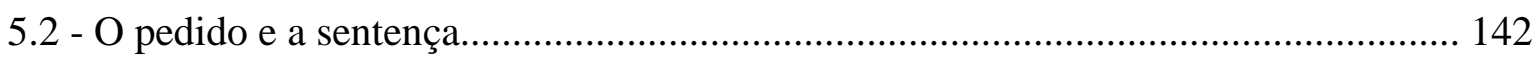

5.2.1 - Aspectos polêmicos ........................................................................... 142

5.2.2 - Estudo de caso: o controle de constitucionalidade e a tutela coletiva.............. 148 
5.3 - A coisa julgada.

5.3.1 - Aspectos polêmicos.

5.3.2 - Estudo de caso: coisa julgada e tutela coletiva. 158

5.4 - A execução. 162

5.4.1 - Aspectos polêmicos 162

5.4.2 - Estudo de caso: a liquidação da sentença coletiva. 166

Considerações conclusivas. 169

Bibliografia.. 176

Anexos. 187 


\section{CONSIDERAÇÕES PRELIMINARES}

Este estudo tem por objetivo investigar a tutela coletiva dos interesses individuais homogêneos no Direito brasileiro, procurando entender como se comportam em juízo, como se adaptam aos instrumentos processuais existentes e quando a sua defesa judicial é possível, necessária e conveniente. Inicia-se com a pesquisa sobre as características dos próprios interesses, passa pela crítica dos atributos da sua tutela coletiva e procura aplicar os resultados dessa investigação aos problemas antigos e atuais que mais têm dificultado a sua proteção jurisdicional.

Ainda que o desenvolvimento do trabalho tenha exigido a análise dos principais institutos processuais aplicáveis, não constituiu objetivo do estudo a avaliação extensiva das categorias do processo coletivo a eles relativas, nem a formulação de propostas para revisão dos diplomas normativos vigentes nessa matéria. Tampouco foi objetivo dissertar detalhadamente sobre o procedimento aplicável a essa tutela judicial, embora os principais problemas que se colocam nesse percurso tenham sido abordados.

Como a investigação foi centrada na defesa coletiva em juízo, o ponto de vista escolhido foi o dos interesses individuais homogêneos representados no polo ativo, tendo em vista que a possibilidade de ações contra coletividades é um tanto remota no direito brasileiro ${ }^{1}$, senão nula, a rigor, de lege lata ${ }^{2}$. A perspectiva escolhida também foi a do procedimento comum, de maneira que o mandado de segurança coletivo não foi abordado, não obstante a sua aplicabilidade e utilidade na defesa de interesses individuais homogêneos.

A importância do tema deste trabalho decorre das dificuldades maiores naturalmente enfrentadas para adaptação da tutela coletiva para o trato de interesses individuais, da relativa carência de estudos específicos na nossa literatura jurídica, e do aumento vertiginoso de demandas versando esses interesses trazidas ao Poder Judiciário, tanto na jurisdição singular como na coletiva, intensificando os problemas de acesso à justiça, de um lado, e de organização judiciária, de outro.

\footnotetext{
${ }^{1}$ V. Pedro Lenza, Teoria geral da ação civil pública. São Paulo: Editora Revista dos Tribunais, 2003, p. 200.

${ }^{2}$ V. Pedro da Silva Dinamarco, Ação civil pública. São Paulo: Saraiva, 2001, p. 268-273.
} 
No capítulo 1 são estudadas as características dos interesses individuais homogêneos, desde os motivos da utilização do termo interesse até os aspectos coletivos neles verificados, passando pelas suas diferenças em relação aos interesses essencialmente coletivos e aos puramente individuais. O capítulo 2 é dedicado a mostrar as dificuldades da defesa dos interesses individuais homogêneos, seja por conta da sua enorme proliferação, na sociedade moderna em geral e na brasileira em particular, seja pela falta de alternativas, na prática, à jurisdição estatal, cuja oferta de serviços mostra-se atualmente em desequilíbrio com a demanda e em descompasso com a qualidade desejada.

O capítulo 3 examina os requisitos necessários à tutela jurisdicional dos interesses individuais homogêneos, ou seja, a possibilidade dessa tutela, sua utilidade e sua conveniência. O capítulo 4 contém um panorama das dificuldades dessa tutela coletiva, com uma breve abordagem da situação, anterior e atual, do Direito norte-americano, onde essa tutela atingiu um grau de desenvolvimento superior ao nosso e já serviu de inspiração ao legislador nacional, especificamente no tocante aos interesses individuais homogêneos. Nesse capítulo, discorre-se também sobre os principais problemas brasileiros nesse campo, os antigos e os atuais, bem como os instrumentos legais com os quais o equacionamento daqueles foi tentado e as soluções legislativas propostas para resolução destes.

O capítulo 5 encerra o estudo com a apresentação, avaliação e tomada de posição a respeito de quatro temas centrais na tutela de interesses individuais homogêneos, isto é, legitimação para agir, pedido e sentença, coisa julgada e execução. Cada uma das quatro partes do capítulo é seguida de um estudo de caso recolhido nos principais tribunais nacionais nos quais alguns desses temas foram discutidos, apontando-se, com base nas conclusões obtidas no estudo, os entendimentos que podem ser considerados corretos e os que se apresentam em desacordo com elas, acompanhados da respectiva demonstração.

Tratando-se de uma monografia de cunho predominantemente teórico, em que o conhecimento experimental (jurisprudência) também está registrado em escritos, a metodologia de trabalho utilizada constituiu-se de leitura, análise, resumo, interpretação, sistematização e compilação de textos, livros e revistas periódicas dedicados ao tema, além de relatórios e documentos pertinentes aos assuntos tratados, incluindo os disponíveis na rede mundial de computadores (Internet). A ênfase da pesquisa recaiu sobre a doutrina e jurisprudência nacionais, aliada à experiência norte-americana na tutela coletiva. 


\title{
CAPÍTULO 1 - AS CARACTERÍSTICAS DOS INTERESSES INDIVIDUAIS HOMOGÊNEOS
}

\begin{abstract}
1.1 - Interesses e direitos; 1.2 - Interesses individuais e interesses transindividuais; 1.3 - Interesses essencialmente coletivos $\mathrm{e}$ interesses episodicamente coletivos; 1.4 - Interesses individuais homogêneos; 1.5 - A dimensão coletiva dos interesses individuais homogêneos.
\end{abstract}

\section{1 - Interesses e direitos}

A distinção entre a noção de interesses e a de direitos não tem sido muito discutida entre os estudiosos do Direito, exceto no tema da tutela coletiva. Provavelmente, a explicação pode ser encontrada no objeto da jurisdição coletiva em comparação com o da jurisdição singular, normalmente foco das demais disciplinas jurídicas.

Na jurisdição singular, são poucos os casos de configuração de interesses juridicamente relevantes e, menos ainda, de interesses judicialmente tuteláveis que não possam ser definidos como direitos. O próprio arquétipo da lide singular, legada do Direito Romano, sugere a titularidade de direitos, absolutamente relevantes e perfeitamente tuteláveis, que uma pessoa possa opor a outra.

$\mathrm{Na}$ jurisdição coletiva, ao contrário, a relatividade do conceito de legitimidade ad causam acomoda melhor a defesa de posições jurídicas que não sejam titularizadas pelos interessados da maneira tradicionalmente representada pelos direitos subjetivos.

Já se vê que interesses e direitos subjetivos são espécies de um mesmo gênero, mas aqueles possuem menos atributos do que estes. Interesses simples, ou juridicamente irrelevantes, podem ser conceituados como sendo ligações psicológicas entre um sujeito e um bem da vida, incapazes de sujeitarem terceiros por não receberem tutela do Estado. Interesses legítimos e direitos subjetivos, por sua vez, são também aspirações ligando pessoas a coisas, mas que recebem proteção estatal, assumindo a feição de posições jurídicas, já que passam a compor relações jurídicas: os interesses assim qualificados, por isso denominados legítimos, ou juridicamente relevantes, recebem do 
Estado uma proteção relativa, limitada, enquanto os direitos subjetivos merecem defesa estatal ampla, incluindo aquela de natureza jurisdicional.

Sendo assim, a distinção é mais de intensidade da proteção que de substância, ou seja, "não há, propriamente, uma diferença essencial, e sim, uma diferença em termos de intensidade quanto à proteção estatal: enquanto os direitos subjetivos se beneficiam de uma proteção máxima, e os interesses simples são praticamente 'desconhecidos', os interesses legítimos se apresentam a meio caminho: embora não se constituam em prerrogativas ou títulos jurídicos oponíveis erga omnes, beneficiam de uma proteção limitada, ao menos no sentido de não poderem ser ignorados ou preteridos" ${ }^{3}$. Também é possível incluir na mesma ordem de ideias outras situações jurídicas que também se diferenciam apenas pela intensidade da proteção estatal, desde aquela sem qualquer amparo, ou seja, os interesses simples, até aquela merecedora dos instrumentos protetivos mais amplos e eficientes, isto é, as liberdades públicas, passando pelos interesses legítimos e os interesses jurídicos ${ }^{4}$.

É inegável, porém, a reduzida importância doutrinária dessa distinção ${ }^{5}$. A partir do momento em que o Estado prevê instrumentos de defesa de interesses jurídicos, estes adquirem o status, do ponto de vista teórico e prático, de direitos ${ }^{6}$. Por essa razão,

\footnotetext{
${ }^{3}$ Rodolfo de Camargo Mancuso. Interesses difusos. 6a ed. rev. atual. amp. São Paulo: Editora Revista dos Tribunais, 2004, p. 76.

${ }^{4}$ Ada Pellegrini Grinover explica que "a doutrina tem revelado a distinção entre interesses juridicamente protegidos e direitos subjetivos: em contraposição aos interesses juridicamente irrelevantes, todos os interesses relevantes para o direito constituem situações jurídicas subjetivas, ou seja, posições ocupadas nas relações jurídicas, possibilitando realizar os interesses juridicamente protegidos ou obrigando a sujeitar-selhes. Dentro dessas situações jurídicas subjetivas, existe uma graduação, conforme a relevância do interesse para o direito: umas recebem proteção direta, plena e específica (os direitos subjetivos); outras, proteção indireta, limitada e genérica, matizando-se em direitos condicionados, interesses legítimos, simples interesses, poderes e faculdades" (A tutela jurisdicional dos interesses difusos. In: Revista Brasileira de Direito Processual n. 16, Rio de Janeiro, Forense, 1978, p. 13-42).

${ }^{5}$ V. Rodolfo de Camargo Mancuso (Manual do consumidor em juízo. $3^{\text {a }}$ ed. rev. atual. amp. São Paulo: Saraiva, 2001, p. 29), embora este autor reafirme a preferência pela denominação "interesses".

${ }^{6}$ Para Ricardo de Barros Leonel (Manual do processo coletivo. São Paulo: Editora Revista dos Tribunais, 2002, p. 89): “Assim, para o processo coletivo - pela ausência de distinção axiológica, pela falta de relevância prática, e pelo tratamento dado pelo legislador -, válido é o exame indistinto das posições ou situações concretas de vantagem protegidas juridicamente, como 'direitos' ou 'interesses' supra-individuais. As conseqüências no plano normativo substancial e processual, para a tutela jurisdicional, serão as mesmas.”. Cf. também Kazuo Watanabe (In: GRINOVER, Ada Pellegrini et al. Código brasileiro de defesa do consumidor comentado pelos autores do anteprojeto. $5^{\mathrm{a}}$ ed. rev. atual. amp. Rio de Janeiro: Forense Universitária, 1998, p. 503).
} 
alguns estudos na área da tutela coletiva têm preferido a denominação direitos em lugar de interesses ${ }^{7}$.

Neste trabalho, será utilizada a noção de interesse, por três razões.

A primeira razão é que, como já mencionado, a tutela coletiva abrange também a proteção de posições jurídicas que recebem um amparo estatal menos intenso do que em geral acontece com os direitos tradicionais, defendidos na jurisdição singular. Mais do que isso, o acesso à jurisdição coletiva não depende da titularidade exclusiva de uma situação teoricamente vantajosa, como ocorre na jurisdição singular, segundo ensinamento de Rodolfo de Camargo Mancuso ${ }^{8}$. Nesse caso, tratar todas essas posições jurídicas como interesses é mais apropriado.

A segunda razão é que a denominação interesses, mesmo que admitida como sinônimo de direitos para todos os fins práticos, ainda é a mais utilizada no campo da tutela coletiva. Considerando a utilidade da padronização de linguagem técnica, afigura-se mais conveniente a opção por essa expressão.

A terceira razão é a opção legislativa feita pela Assembleia Constituinte que aprovou a atual Constituição Federal, utilizando o termo interesses duas vezes ao tratar das atribuições do Ministério Público na jurisdição civil, no âmbito da tutela coletiva (arts. 127 e 129, inciso III). Ao utilizar o termo interesses, o legislador constituinte atribuiu a essa expressão um status que não pode ser ignorado. Tanto é verdade que essa denominação foi adotada na legislação superveniente, dentro da qual se destacam o Código de Defesa do Consumidor e a Lei Federal n. 8.078, de 11/09/1990, no art. 81 e seguintes.

\footnotetext{
${ }^{7}$ V. Teori Albino Zavascki, Processo Coletivo - Tutela de direitos coletivos e tutela coletiva de direitos. $2^{\mathrm{a}}$ ed. rev. atual. São Paulo: Editora Revista dos Tribunais, 2007; Rizzato Nunes, As ações coletivas e as definições de direito difuso, coletivo e individual homogêneo (In: MAZZEI, Rodrigo; NOLASCO, Rita (coord.). Processo civil coletivo. São Paulo: Quartier Latin, 2005, p. 82); Antonio Gidi, Coisa julgada e litispendência em ações coletivas. São Paulo: Saraiva, 1995, p. 17-18. Este último autor chega a rejeitar a utilização da terminologia "interesse" por entender que a diferenciação em relação ao conceito de "direito" constitui "preconceito ainda que inconsciente em admitir a operacionalidade técnica do conceito de direito superindividual", justificado por teorias caracterizadas pelo "ranço individualista que marcou a dogmática jurídica do século XIX".

8 "Embora seja defensável a posição dos que propugnam pela sinonímia ou pela equivalência entre interesses e direitos metaindividuais, cremos que a expressão interesses é mais adequada a esse campo, dado que no processo coletivo a situação legitimante não releva da titularidade exclusiva de uma afirmada posição de vantagem" (Jurisdição coletiva e coisa julgada. São Paulo: Editora Revista dos Tribunais, 2007, p. 98).
} 
1.2 - Interesses individuais e interesses transindividuais

Os interesses individuais são objeto de tutela jurídica estatal, com maior ou menor intensidade, desde os primórdios da civilização. A nossa ordem jurídica, derivada da matriz da civil law, exibe até hoje traços muito fortes do Direito Romano, responsável pelo admirável desenvolvimento, ainda na Antiguidade, da maioria dos conceitos atualmente utilizados para reger a jurisdição singular, na qual duas partes, ainda que eventual e limitadamente pluralizadas, titularizam com exclusividade posições jurídicas em conflito.

A defesa dos interesses coletivos, a seu turno, encontra antecedentes históricos igualmente antigos, mas inicialmente se subordinando à antiga dicotomia público-privado, no sentido de que se a ação não veiculava direitos titularizados exclusivamente por um indivíduo, então se tratava de defesa de interesse público, sem qualquer espaço para a tutela de interesses de grupos limitados. É exemplo dessa jurisdição, na perspectiva histórica, a actio popularis dos romanos, da qual a nossa ação popular é descendente direta.

Ao caracterizar-se pela correspondência entre parte e titular do interesse pretensamente violado, a defesa dos interesses individuais jamais sofreu as vicissitudes das transformações históricas pelas quais passaram os interesses dos grupos de indivíduos. Se na Antiguidade Clássica os interesses coletivos confundiam-se com os interesses públicos, sob a forte influência estatal, a Idade Média e o enfraquecimento do poder central trouxeram a organização de corporações, ainda não caracterizadas em associações e sociedades.

Ocorre que, nessa época, os membros de uma corporação compartilhavam o mesmo modo de vida e os mesmos interesses; no dizer de Márcio Flávio Mafra Leal, tratava-se de um "grupo coeso"9. Por essa razão, a questão da legitimidade para propor a tutela dos interesses da corporação era considerada secundária, pois não era um problema: não se cogitava que pessoas tão afinadas socialmente, com trabalhos,

\footnotetext{
${ }^{9}$ Ações Coletivas: história, teoria e prática. Porto Alegre: Sergio Antonio Fabris Editor, 1998, p. 31.
} 
moradias, hábitos e valores muito semelhantes ou idênticos, pudessem ter interesses divergentes em qualquer questão que lhes dissesse respeito.

Modernamente, após as revoluções liberais ${ }^{10}$, os mesmos interesses coletivos passaram a atingir grupos muito diferentes. Com o mais completo estímulo das novas ideias libertárias e individualistas, aos poucos essas pessoas deixaram de ser plenamente identificadas, tornando-se indivíduos na mais exata acepção da palavra, bastante diferentes entre si, ainda que, eventualmente, se encontrassem na situação de possuírem um interesse em comum.

Foi nesse contexto que começaram as dificuldades da defesa dos interesses coletivos. Se os indivíduos são diferentes, como pressupor que um deles tenha legitimidade para demandar por todos na defesa desse interesse comum? Como estender os efeitos da tutela coletiva sobre os que não estiverem em juízo, se não se pode pressupor qual o legítimo interesse desses outros? Como exigir que grandes grupos compareçam em juízo? Como fazer isso se os membros do grupo nem sequer são determinados?

Essas questões ainda hoje são discutidas, e as soluções encontradas nem sempre se afiguram satisfatórias. No capítulo 4 o assunto será tratado detalhadamente, dentro do enfoque específico deste trabalho.

\section{3 - Interesses Essencialmente Coletivos e Interesses Episodicamente Coletivos}

A classificação dos interesses ou direitos, mediante fixação das suas categorias e subcategorias, é matéria controvertida na doutrina. Desde meados do século passado, quando a tradicional dicotomia público-privado começou a parecer insuficiente para a classificação das posições jurídicas ${ }^{11}$, as propostas de novas categorias classificatórias se multiplicaram, sem qualquer convergência de entendimentos, tornando o

\footnotetext{
${ }^{10}$ Assim denominadas, em conjunto, a "Revolução Americana", movimento que levou à independência dos Estados Unidos da América, em 1776, e a "Revolução Francesa", movimento responsável pela queda da monarquia na França, em 1789. Também conhecidas por "Revoluções Atlânticas", foram ambas contra os valores feudais e monárquicos (rigidez social, aristocracia, absolutismo) e a favor dos valores capitalistas e republicanos (mobilidade social, meritocracia, democracia). A esse respeito, v. Edward MacNall Burns, História da civilização ocidental. $3^{\mathrm{a}}$ ed. Porto Alegre: Globo, 1975, capítulos 21 e 25.

${ }^{11}$ V. Hugo Nigro Mazzilli, A defesa dos interesses difusos em juízo. 15a ed. rev. amp. atual. São Paulo: Saraiva, 2002, p. 41.
} 
panorama desses conceitos pouco definido, finalidade mais importante de qualquer classificação $^{12}$.

Algo semelhante ocorre com a classificação dos próprios interesses coletivos. Parece consolidada a divisão nas categorias de interesses difusos, coletivos em sentido estrito e individuais homogêneos, especialmente por ter sido adotada pelo legislador (art. 81 do Código de Defesa do Consumidor, aplicável à tutela coletiva em geral por força do art. 21 da Lei n. 7.347/85), mas, a partir daí, não há muito consenso.

Uma forma de ver a questão de modo mais claro é considerar que uma só classificação não é suficiente para dar conta de todas as características e peculiaridades dos interesses coletivos, uma vez que algumas das mais importantes delas possuem naturezas muito diversas, como é o caso da indeterminação subjetiva e da indivisibilidade objetiva. Evidentemente, cada uma dessas características pode constituir um critério classificatório, de modo a ser natural que nem todos os interesses coletivos figurem na mesma situação em todas as classificações que delas decorrem.

Por exemplo, é possível classificar os interesses coletivos com base na indeterminação dos sujeitos. Nesse caso, é evidente que os interesses difusos, por exibirem indeterminação absoluta, opõem-se tanto aos individuais homogêneos quanto aos coletivos stricto sensu, considerando que ambas as categorias abarcam interesses nos quais os sujeitos podem ser determinados. Se essa característica for eleita como a mais relevante para fins de tutela jurisdicional, sob um enfoque qualquer (legitimidade, coisa julgada ou qualquer outro), não apenas a classificação adequada será essa, feita com base nessa característica, mas também será natural que se tratem os interesses individuais homogêneos e os coletivos stricto sensu de modo bastante semelhante, ao mesmo tempo em que caberá tratamento muito diferenciado aos interesses difusos.

Por outro lado, é possível também classificar os interesses coletivos com base na indivisibilidade do objeto, hipótese em que haverá clara separação entre os interesses individuais homogêneos, de um lado, e os difusos e coletivos, de outro, considerando que só os primeiros mostram total divisibilidade. Então, tal classificação,

\footnotetext{
${ }^{12}$ Pedro Lenza apresenta as classificações dicotômica, dicotômica mitigada e tricotômica, segundo as quais os interesses metaindividuais seriam, respectivamente, uma espécie de interesses públicos, uma subcategoria de interesses públicos e uma terceira categoria, intermediária entre os interesses públicos e os privados, (Teoria geral da ação civil pública, São Paulo, Editora Revista dos Tribunais, 2003, p. 51 e seguintes).
} 
quando considerada adequada aos fins colimados, levará a um manejo análogo entre os interesses difusos e coletivos, mas muito diverso em relação aos individuais homogêneos.

Seja como for, a posição dos interesses individuais homogêneos aparece sempre como a mais discutida. É antiga a concepção de que há interesses essencial, ontológica ou naturalmente coletivos, concernentes a um número indeterminado de sujeitos e referidos a um objeto indivisível, e outros interesses que são episódica, contingencial ou acidentalmente coletivos, quando dizem respeito a um objeto divisível ${ }^{13}$, sendo os primeiros constituídos pelos interesses difusos e coletivos em sentido estrito, enquanto os segundos corresponderiam, exatamente, aos interesses individuais homogêneos. Em função dessa ideia, tais interesses são, por vezes, considerados à parte dos demais, dividindo-se os interesses coletivos em transindividuais (difusos ou coletivos stricto sensu) e individuais homogêneos $^{14}$; em outras ocasiões, é considerada a tripartição adotada pela legislação, como já mencionado, isto é, interesses difusos, coletivos stricto sensu e individuais homogêneos ${ }^{15}$; e, em outros momentos, os interesses individuais homogêneos são considerados uma espécie dos interesses coletivos ${ }^{16}$.

Esse pode ser um dos reflexos do tratamento preconceituoso dedicado aos interesses individuais homogêneos por grande parte dos profissionais do Direito ${ }^{17}$, questão diretamente relacionada à maior parte das vicissitudes sofridas por esses interesses, e que será objeto de estudo mais detalhado no capítulo 2.

Muitas vezes, as divergências e hesitações teóricas residem na preocupação com a aplicabilidade da tutela coletiva aos interesses individuais homogêneos. A colocação desses interesses no quadro geral dos interesses coletivos tem dependido da preocupação do estudioso com a possibilidade da sua tutela coletiva, ou seja,

\footnotetext{
${ }^{13}$ V. José Carlos Barbosa Moreira, Ações coletivas na constituição federal de 1988. In: Revista de Processo n. 61, São Paulo, Editora Revista dos Tribunais, jan./mar. 1991, p. 188.

${ }^{14}$ V. Teori Albino Zavascki, Processo Coletivo - Tutela de direitos coletivos e tutela coletiva de direitos. $2^{\mathrm{a}}$ ed. rev. atual. São Paulo: Editora Revista dos Tribunais, 2007, p. 43.

15 V. Ricardo de Barros Leonel, Manual do processo coletivo. São Paulo: Editora Revista dos Tribunais, 2002, p. 98 .

${ }^{16}$ V. RE n. 163-231-3/SP, Relator Min. Maurício Corrêa, julgamento de 26/02/97.

${ }^{17}$ V. Aloísio Gonçalves de Castro Mendes, Ações coletivas: no direito comparado e nacional. São Paulo: Editora Revista dos Tribunais, 2002. O autor chega a comentar que "os direitos individuais são vistos, por vezes, como passageiros de segunda classe, ou até indesejáveis, dentro desse meio instrumental que é a tutela judicial coletiva”.
} 
quanto maior essa preocupação, mais integrados aos demais interesses transindividuais eles aparecem; quanto menor essa preocupação, de maneira mais segregada eles são figurados. Destacam-se as diferenças em relação aos interesses difusos e coletivos quando não há preocupação com a exclusão da tutela coletiva de interesses individuais; quando existe inquietação a esse propósito, tende-se a mitigar tais divergências.

Dentro desse contexto, independentemente da posição adotada, é imperioso considerar a dimensão coletiva dos interesses individuais homogêneos, ou seja, qual a importância desses interesses, considerados no seu conjunto, em comparação com sua natureza intrinsecamente individual. Esse assunto será tratado na parte final deste capítulo.

\section{4 - Interesses individuais homogêneos}

Como é evidente, a dificuldade de classificação dos interesses individuais homogêneos em nada altera a sua natureza. Produto direto da sociedade moderna e de seus conflitos de massa, como será estudado de modo mais aprofundado no capítulo 2, os interesses individuais homogêneos caracterizam-se, sobretudo, por constituírem interesses individuais que merecem ser, sob determinadas condições, de maneira episódica ou acidental, tutelados coletivamente. Nesse sentido há uma clara e inegável oposição aos interesses difusos e coletivos stricto sensu, que são interesses coletivos na sua essência, ou seja, sob nenhum aspecto são titularizados por uma pessoa, mas sempre por uma coletividade, maior ou menor, com membros determinados ou não.

Na verdade, a própria denominação interesses individuais homogêneos já exibe dois enunciados: de um lado, trata-se de interesses ontologicamente individuais, não coletivos; de outro lado, que consistem numa multiplicidade de interesses individuais apresentando um determinado grau de uniformidade ou homogeneidade ${ }^{18}$, sua característica mais importante.

\footnotetext{
${ }^{18}$ Homogêneo é adjetivo que vem do grego homogenes, de homo ("semelhante") + genes ("gênero"), ou seja, o "que é da mesma natureza que outro; idêntico, igual, análogo" (v. Caldas Aulete, Dicionário contemporâneo da língua portuguesa. $3^{\mathrm{a}}$ ed. Rio de Janeiro: Delta, 1980).
} 
A lei define os interesses individuais homogêneos como "aqueles decorrentes de origem comum" (art. 81 da Lei n. 8.078/91). Isso significa que não se exige uma relação jurídica base entre os titulares desses interesses, nem entre eles e a parte contrária, necessariamente. Basta que haja uma origem comum, ainda que inexista unidade factual e temporal ao mesmo tempo. Assim, serão interesses individuais homogêneos os das vítimas de propaganda enganosa de produto nocivo à saúde, ainda que tenham sido atingidas por ela em regiões distantes e num largo espaço de tempo ${ }^{19}$.

De fato, esses interesses poderiam ter sido nomeados pelo legislador, por exemplo, como "interesses individuais relevantes", ou de "interesses individuais de origem comum". Não o foram porque a homogeneidade consiste em condição imprescindível de possibilidade da sua tutela na forma coletiva. Pela mesma razão, a primazia dessa característica não é sequer objeto de controvérsia, merecendo análise detalhada, a ser feita no capítulo 3 deste trabalho.

Merecem detalhamento, porém, neste momento, as características dos interesses individuais homogêneos. Em primeiro lugar, tratando-se de interesses essencialmente individuais, os interesses individuais homogêneos, ontologicamente considerados, são:

a) divisíveis, ou seja, o interesse de cada pessoa pode ser destacado dentro do conjunto de interesses tomados coletivamente;

b) apropriáveis individualmente, quer dizer, é possível atribuir a cada um o seu próprio interesse;

c) disponíveis (salvo exceções previstas em lei), isto é, o interessado pode transigir ou renunciar ao seu interesse;

d) transmissíveis, porque a sua titularidade pode ser transmitida por ato inter vivos ou causa mortis;

${ }^{19}$ O exemplo é de Kazuo Watanabe (In: GRINOVER, Ada Pellegrini et al. Código brasileiro de defesa do consumidor comentado pelos autores do anteprojeto. $5^{\text {a }}$ ed. rev. atual. amp. Rio de Janeiro: Forense Universitária, 1998, p. 629). 
e) representáveis em juízo pelo próprio titular, cuja substituição no polo ativo depende de ato ou fato jurídico específico, como o contrato, sucessão causa mortis, usucapião ${ }^{20}$.

Comparativamente considerados, dentro do quadro geral dos interesses coletivos, os interesses individuais homogêneos são ${ }^{21}$ :

a) episodicamente transindividuais, pois só recebem tratamento coletivo sob certas condições, estudadas mais adiante, no capítulo 3;

b) subjetivamente determinados, quer dizer, seus titulares podem ser conhecidos um a um;

c) diretamente reparáveis, ou seja, a reparação dos danos aos bens lesados é feita diretamente, indenizando-se seus titulares.

Reciprocamente considerados, os interesses individuais homogêneos são:

a) decorrentes de uma origem comum ${ }^{22}$;

b) referidos a um só obrigado, isto é, no polo ativo da obrigação há diversos credores, mas no polo passivo só há um devedor ou, quando muito, vários devedores coautores da mesma lesão, ainda que possa haver outros responsáveis.

A caracterização dos interesses individuais homogêneos não se confunde com a caracterização da sua tutela. Uma vez diferenciados dos interesses difusos e coletivos, resta saber se a tutela desses interesses individuais pode ou deve ser feita de maneira coletiva. Essa resposta deve ser buscada no perfil que esse tipo de tutela coletiva deve apresentar e na necessidade de que ela seja feita de forma coletiva. Essa matéria será desenvolvida no capítulo 3 deste trabalho.

\footnotetext{
${ }^{20}$ V. Teori Albino Zavascki, Processo Coletivo - Tutela de direitos coletivos e tutela coletiva de direitos. $2^{\mathrm{a}}$ ed. rev. atual. São Paulo: Editora Revista dos Tribunais, 2007, p. 44.

${ }^{21}$ V. Pedro Lenza, Teoria geral da ação civil pública. São Paulo: Editora Revista dos Tribunais, 2003, p. 64.

${ }^{22} \mathrm{O}$ sentido da expressão origem comum dos interesses individuais homogêneos será mais bem investigado no capítulo 3 deste trabalho.
} 
1.5 - A dimensão coletiva dos interesses individuais homogêneos

A natureza individual dos interesses individuais homogêneos, obviamente, não pode ser contestada. A sua própria denominação já indica tratar-se de interesses divisíveis e apropriáveis. Mas é exatamente por isso que causa estranheza, para quem estuda o tema pela primeira vez, o fato de tais interesses serem considerados, tratados e disciplinados juntamente com interesses tipicamente coletivos, caso dos interesses coletivos stricto sensu e dos interesses difusos.

O tratamento conjunto, por sua vez, sugere que os interesses individuais homogêneos, sob certo enfoque, devem possuir também uma natureza coletiva. É intuitivo que conceitos tratados conjuntamente devem apresentar similitudes, pelo menos o bastante para justificar essa forma de tratamento.

E é o que de fato acontece, pois os interesses individuais homogêneos apresentam também, sem dúvida, uma dimensão coletiva.

Em primeiro lugar, é preciso lembrar que os interesses individuais homogêneos são também interesses transindividuais, no sentido de que transcendem a esfera de interesses de qualquer um dos seus titulares particularmente considerado. Por outras palavras, são interesses que afetam simultaneamente um conjunto de pessoas, muitas vezes muito grande, ainda que algumas delas em maior intensidade ou por mais tempo. Basta ponderar que a nota distintiva desses interesses é a homogeneidade, e essa característica só faz sentido quando tais interesses são considerados reciprocamente, uns em relação aos outros da mesma espécie ${ }^{23}$. Ora, se a nota característica mais importante desses interesses só é aferível na perspectiva coletiva, não há como negar que se trata, também, de interesses coletivos em sentido amplo.

Evidentemente, não são transindividuais no sentido de não serem apropriáveis individualmente ou de seus titulares serem indetermináveis, mas é preciso entender que o caráter coletivo é muito mais complexo que a mera possibilidade de apropriação ou de determinação dos titulares. Se, do ponto de vista dos titulares, a violação

\footnotetext{
${ }^{23}$ Para Antonio Gidi, "percebe-se, nitidamente, ser a homogeneidade dos direitos individuais um conceito que bem poderia designar-se como relacional: um direito individual é homogêneo apenas em relação a um outro direito individual derivado da mesma origem (origem comum). Não há um direito individual homogêneo, mas direitos individuais homogeneamente considerados" (Coisa julgada e litispendência em ações coletivas. São Paulo: Saraiva, 1995, p. 30).
} 
pode representar a sujeição a prejuízos muito diferentes, do ponto de vista do violador não há qualquer diferença ontológica, por exemplo, entre o ato de poluir o ar sem lesar interesses individuais e fazer o mesmo provocando doenças pulmonares na população vizinha.

Em segundo lugar, os interesses individuais homogêneos derivam de uma violação coletiva de direitos, ou seja, a lesão que constitui sua origem comum consiste, por assim dizer, num único ato objetivamente coletivo, no sentido de que atinge a esfera jurídica de várias pessoas ao mesmo tempo ${ }^{24}$. Isso provoca duas consequências inexistentes quando de uma lesão a interesse individual e que apresentam um efeito sinérgico, uma reforçando a outra. De um lado, a lesão coletiva agride com mais força a paz social, uma vez que alcança um número maior de pessoas, provocando, consequentemente, uma insatisfação mais forte na sociedade. Não há dúvida de que uma violação a direitos do consumidor por parte de uma grande cadeia de lojas, por exemplo, tendo em vista a vulnerabilidade da posição dos lesados, produz grande revolta social, não apenas entre os atingidos, mas também entre as outras pessoas, que naturalmente se identificam com aqueles e temem ver-se, no futuro, na mesma posição desvantajosa.

De outro lado, a lesão coletiva, por atingir, com um mesmo ato, ainda que repetido ao longo do tempo, uma classe inteira de pessoas, é passível de divulgação muito mais fácil e rápida. Assim como os interesses individuais homogêneos são um produto da sociedade de massa ${ }^{25}$, a maior facilidade e a maior velocidade da difusão da informação também o são, incluindo a divulgação das violações que os originam. Nesse contexto, é natural que a intranquilidade social seja semeada mais facilmente por uma lesão coletiva, que prejudique de uma só vez uma coletividade inteira, capaz de ser divulgada por uma única notícia de jornal, por exemplo, do que por inúmeras lesões individuais, mesmo que afetem mais pessoas.

Pode-se dizer, nesse sentido, que a violação da qual resultam os interesses individuais homogêneos, especialmente quando de fato atinge grande número de sujeitos, constitui um dano coletivo maior do que a soma de todos os danos individuais. A esse propósito, José Carlos Barbosa Moreira explica que "o fenômeno tem dimensões

\footnotetext{
${ }^{24}$ E não um ato subjetivamente coletivo, isto é, praticado por várias pessoas ao mesmo tempo.

${ }^{25} \mathrm{~V}$. capítulo 2.
} 
diferentes quando olhado pelo prisma individual e quando olhado por um prisma global. Curiosamente, aquela proposição aritmética relativa às parcelas e à soma falha. Aqui, na verdade, há casos em que a soma é algo mais do que simplesmente o conjunto das parcelas, exatamente porque o fenômeno assume, no contexto da vida social, um impacto de massa"26.

Em terceiro lugar, a abrangência coletiva dessas lesões, pelo seu potencial de causar uma multiplicidade de conflitos, exige uma resposta do ordenamento jurídico, mediante a atuação do Poder Judiciário ou não, a qual atinja simultaneamente, com maior eficácia, os fins de prevenir, reprimir e reparar os prejuízos sofridos. Além de mais prementes, essas finalidades são muito mais difíceis de serem alcançadas, uma vez que tais violações atingem, ao mesmo tempo, diversas pessoas, muitas vezes em diferentes locais e com distintos prejuízos individuais.

Em quarto lugar, existe uma clara conexão entre os interesses difusos e coletivos stricto sensu e os interesses individuais homogêneos. Essa conexão é revelada, sobretudo, pela circunstância de que o mesmo dano causador dos interesses individuais homogêneos constitui um dano a interesses difusos ou coletivos. O mesmo ato subjetivamente coletivo que constitui a origem comum determinante da formação de interesses individuais homogêneos é também responsável, ao mesmo tempo, pela violação de outras espécies de interesses coletivos em sentido amplo.

Os interesses difusos e coletivos caracterizam-se, como visto, pela indivisibilidade objetiva e pela indeterminação subjetiva ${ }^{27}$. Porém, quando qualquer bem difuso ou coletivo sofre um dano, ordinariamente, não apenas a coletividade como tal é atingida; pessoas individualizadas normalmente são também atingidas e passam a ostentar um interesse nitidamente individual, porque atribuível e apropriável por cada uma delas, além de homogêneo em relação aos demais também originados pelo mesmo ato, ostentando uma origem comum ${ }^{28}$.

\footnotetext{
${ }^{26}$ Ações coletivas na constituição federal de 1988. In: Revista de Processo n. 61, São Paulo, Editora Revista dos Tribunais, jan./mar. 1991, p. 189.

27 Ainda que, no caso dos coletivos, a indivisibilidade seja apenas relativa e seus titulares sejam determináveis.

28 Evidentemente, a própria vida em sociedade implica feixes de relações jurídicas que se cruzam constantemente, de modo que é natural a conexão de interesses, incluindo os puramente individuais. Não se
} 
Os exemplos mais imediatos são os que envolvem os casos de tutela coletiva mais comuns hoje em dia, isto é, ligados ao direito ao meio ambiente saudável e aos direitos do consumidor: o interesse difuso na preservação de um rio que abastece determinada população de água é conexo aos interesses individuais homogêneos dos membros dessa população na reparação dos prejuízos à saúde causados pela poluição provocada por determinada indústria da região ${ }^{29}$; o interesse difuso na divulgação de propaganda comercial fidedigna e lícita apresenta conexão com os interesses individuais homogêneos dos consumidores resultantes de prejuízo por alguma propaganda enganosa ${ }^{30}$; o interesse coletivo dos alunos de determinada escola, de que sejam respeitadas as normas relacionadas aos reajustes das mensalidades, é conexo aos interesses individuais homogêneos dos pais desses alunos pela devolução dos valores que tenham pago a maior em razão do descumprimento da lei.

Note-se que todas essas também são características dos interesses individuais homogêneos, não sendo propriamente fatores de ordem econômica, social ou jurídica que recomendem o seu tratamento processual coletivo, como ocorre com a racionalização e o desafogamento do trabalho do Poder Judiciário, a facilitação do acesso à justiça, o estímulo à maior participação política dos grupos sociais intermediários por meio do processo ou a eliminação de decisões conflitantes.

está negando, portanto, que possa acontecer de uma violação a interesse essencialmente coletivo atingir apenas um interesse individual, que nesse caso não será homogêneo em face de qualquer outro, ou mesmo que possa não atingir qualquer outro interesse. O que se está afirmando é que isso não é o mais comum; da violação a interesses difusos e coletivos, em geral, decorrem violações, mais cedo ou mais tarde, a diversos interesses individuais que apresentam homogeneidade entre si.

${ }^{29}$ V. Álvaro Luiz Valery Mirra, que, ao discorrer sobre a tutela coletiva dos direitos individuais homogêneos das vítimas de danos causados "por intermédio" do meio ambiente,menciona os "danos individuais reflexos decorrentes dos atentados aos bens ambientais" (Ação civil pública e a reparação do dano ao meio ambiente. São Paulo: Juarez de Oliveira, 2002, p. 80-83).

${ }^{30}$ No mesmo sentido, a Súmula n. 2 do Conselho Superior do Ministério Público de São Paulo: "em caso de propaganda enganosa, o dano não é somente daqueles que, induzidos a erro, adquiriram o produto, mas também difuso, porque abrange todos os que tiveram acesso à publicidade". Antonio Gidi igualmente sustenta a conexão entre interesses individuais homogêneos e os interesses essencialmente coletivos (difusos ou coletivos em sentido estrito), também exemplificando com a propaganda enganosa (A class action como instrumento de tutela coletiva dos direitos. São Paulo: Editora Revista dos Tribunais, 2007, p. 284). Kazuo Watanabe também defende que, "no plano sociológico, o conflito de interesses pode dizer respeito, a um tempo, a interesses ou direitos 'difusos' 'individuais homogêneos"” (In: GRINOVER, Ada Pellegrini et al. Código brasileiro de defesa do consumidor comentado pelos autores do anteprojeto. $5^{\mathrm{a}}$ ed. rev. atual. amp. Rio de Janeiro: Forense Universitária, 1998, p. 633). Da mesma forma se manifesta Sérgio Shimura (Tutela coletiva e sua efetividade, São Paulo: Método, 2006, p. 46). 
Por todas essas razões, o enquadramento dos interesses individuais homogêneos na categoria transindividual não é estritamente processual ${ }^{31}$. Se fosse, o tratamento processual coletivo poderia ser destinado a qualquer interesse individual, à escolha do legislador. O fato de que só alguns interesses individuais são suscetíveis de tutela coletiva $^{32}$ já mostra, por si só, a face coletiva ostentada por tais interesses.

É essa face coletiva dos interesses individuais homogêneos que os torna suscetíveis de receberem tutela judicial na jurisdição coletiva e é em função dela que podem apresentar a nota da relevância social e, em consequência, da indisponibilidade. Apenas quando dissipada essa dimensão coletiva, esses interesses voltam à sua natureza puramente individual, deixam de ostentar importância para a coletividade e ficam reduzidos à mesma condição dos interesses meramente patrimoniais, como ocorre, por exemplo, após o reconhecimento judicial da sua exigibilidade, ainda que dependente de liquidação ${ }^{33}$.

A revelação desse aspecto coletivo não significa que os interesses individuais homogêneos deixem de ser individuais, nem mesmo que sua dimensão individual possa ser ignorada, bem ao contrário. Somente com a noção exata do que representam esses interesses será possível idealizar a forma mais eficiente para assegurar a sua tutela pelo ordenamento jurídico, em juízo ou fora dele. Precisamente por esse motivo, é necessário considerar a dimensão coletiva desses interesses para admitir tratar-se de uma categoria bifronte, a meio caminho entre os interesses individuais e os coletivos.

\footnotetext{
${ }^{31}$ Em sentido contrário, Teori Albino Zavascki (Processo Coletivo - Tutela de direitos coletivos e tutela coletiva de direitos. $2^{\mathrm{a}}$ ed. rev. atual. São Paulo: Editora Revista dos Tribunais, 2007, p. 57/58). Todavia, o autor sustenta também que, em certos casos, a violação a interesses individuais homogêneos pode comprometer interesses sociais, transcendendo a esfera individual, dependendo do grau de profundidade ou da extensão da lesão.

${ }^{32}$ V. capítulo 3 .

${ }^{33}$ V. capítulo 5, item 5.1.1.
} 


\section{CAPÍTULO 2 - AS DIFICULDADES DOS INTERESSES INDIVIDUAIS HOMOGÊNEOS}

2.1 - Sociedade moderna e conflitos de massa; 2.2 - Estímulos à litigiosidade; 2.3 - Métodos alternativos de solução de controvérsias; 2.4 - Jurisdição singular e Poder Judiciário; 2.4 .1 A cultura jurídico-processual individualista; 2.4.2 - A estrutura judiciária e o acúmulo de processos.

\section{1 - Sociedade moderna e conflitos de massa}

Tornou-se voz corrente caracterizar a litigiosidade na sociedade moderna como sendo marcada por conflitos de massa. De fato, do desenvolvimento da produção em grande escala, possibilitada pela chamada Revolução Industrial $^{34}$, resultou a chamada produção em massa, ou seja, a disseminação da fabricação de produtos tecnológicos padronizados em enorme quantidade, da qual decorreram relações de troca e de consumo de massa e, inevitavelmente, violação de direitos e litígios também em massa ${ }^{35}$.

Em importante estudo sobre as ações coletivas, José Carlos Barbosa Moreira leciona que "as características da vida contemporânea produzem a emersão de uma série de situações em que, longe de achar-se em jogo o direito ou o interesse de uma única pessoa, ou de algumas pessoas individualmente consideradas, o que sobreleva, o que assume proporções mais imponentes, é precisamente o fato de que se formam conflitos nos quais grandes massas estão envolvidas. É um dos aspectos pelos quais o processo recebe o impacto desta propensão do mundo contemporâneo para os fenômenos de massa: produção de massa, distribuição de massa, cultura de massa, comunicação de massa, e

\footnotetext{
${ }^{34}$ Ocorrida a partir da metade do século XVIII, a Primeira Revolução Industrial, liderada pela Inglaterra, decorreu de dois importantes avanços tecnológicos: a mecanização da manufatura, em especial pelo desenvolvimento do tear mecânico e da máquina a vapor, e a divisão do trabalho a ela inerente. Ambas, em perfeita sinergia, potencializaram o aumento da produtividade, substituindo a antiga produção artesanal pela nascente produção industrial. A Segunda Revolução Industrial, protagonizada pelos Estados Unidos da América a partir de 1860, derivou, entre outros fatores, da substituição do material industrial básico (o ferro pelo aço) e de fontes de energia (o vapor pela eletricidade e pelo petróleo), além do desenvolvimento da manufatura (a produção em série de Henry Ford e a administração científica de Frederick Taylor), provocando novo salto na produtividade industrial. (v. Edward MacNall Burns, História da civilização ocidental. $3^{\mathrm{a}}$ ed. Porto Alegre: Globo, 1975, p. 674)

${ }^{35}$ Cf. Mauro Cappelletti, Formações sociais e interesses coletivos diante da justiça civil. In: Revista de Processo n. 05, São Paulo, Editora Revista dos Tribunais, jan./mar. 1977, p. 130.
} 
por que não, processo de massa?"36. Nas sociedades que já passaram pelo processo de industrialização, o grande crescimento do setor de serviços, comercial e público, com forte demanda pelo processamento de informações, potencializou ainda mais o fenômeno.

Os exemplos são muitos, antigos ou atuais: a indústria alimentícia que comercializa produto defeituoso, causando danos à saúde dos seus consumidores; a indústria automobilística, ao produzir veículos com defeito capaz de provocar acidentes e lesionar condutores, passageiros e pedestres; a escola, quando reajusta as mensalidades escolares em níveis abusivos ou ilegais; a operadora de planos de assistência médica e hospitalar, ao aplicar reajuste elevado às mensalidades; o banco quando deixa de creditar a remuneração correta na conta dos seus investidores; a instituição previdenciária, ao não aplicar o reajuste legalmente fixado aos benefícios que paga; o órgão tributário estatal, que exige dos contribuintes algum tributo inconstitucional.

Nas últimas décadas, os reflexos desse fenômeno dos litígios de massa foram ainda mais intensificados pela particular situação das sociedades na quais exerceu influência. Isso porque essas sociedades, a partir do Pós-Guerra (1945), encontravam-se em processo de reconhecimento do advento dos direitos humanos de terceira geração ${ }^{37}$, bem como em vias de desenvolver mecanismos para promover a garantia da efetividade do acesso à justiça ${ }^{38}$.

No Brasil, a partir da década de 80 do século XX, o retorno ao Estado Democrático de Direito marcou um período de intensa afirmação de direitos, sem grande preocupação com as formas e os meios de efetivá-los, como um desagravo em face do

${ }^{36}$ Ações coletivas na constituição federal de 1988. In: Revista de Processo n. 61, São Paulo, Editora Revista dos Tribunais, jan./mar. 1991, p. 187.

${ }^{37}$ Cf. Norberto Bobbio, A era dos direitos. Tradução de Carlos Nelson Coutinho. Rio de Janeiro: Campus, 1992. A primeira geração corresponde aos direitos civis e políticos, também chamados de liberdades públicas (direito à vida, à liberdade, à igualdade, à propriedade etc.); a segunda geração faz referência aos direitos econômicos, sociais e culturais (direito à educação, à saúde, ao trabalho, ao lazer etc.); a terceira geração diz respeito a direitos de titularidade coletiva (direito ao meio ambiente sadio, à paz, ao desenvolvimento, à autodeterminação dos povos, à qualidade de vida etc.); e a quarta geração aos direitos relacionados às novas conquistas científicas, ou seja, a engenharia genética e a tecnologia da informação (direito à preservação do patrimônio genético, ao uso compartilhado das plantas e organismos vivos, ao sigilo do conteúdo dos bancos de dados etc.). Os direitos humanos de terceira geração, normalmente identificados com os direitos transindividuais, constituem uma categoria ainda excessivamente heterogênea e vaga e permanecem sem efetividade, conforme o autor.

${ }^{38}$ Cf. Mauro Cappelletti e Bryant Garth. Acesso à justiça. Porto Alegre: Sergio Antonio Fabris Editor, 1988, p. 11. Diz o professor italiano que: "De fato, o direito ao acesso efetivo tem sido progressivamente reconhecido como sendo de importância capital entre os novos direitos individuais e sociais, uma vez que a titularidade de direitos é destituída de sentido, na ausência de mecanismos para sua efetiva reivindicação". 
longo período de exceção correspondente ao regime militar (1964-1985). Os mecanismos judiciários (ação civil pública, mandado de segurança coletivo, mandado de injunção, habeas data etc.), porém, não foram esquecidos quando da promulgação da Constituição de 1988, gerando meios de acesso formal e expectativas de proteção dos direitos enumerados no texto constitucional, mas não meios de acesso efetivo e garantias reais de direitos. Por outras palavras, assegurou-se a possibilidade de bater às portas do Estado-juiz, sem assegurar também os meios econômicos para que todos possam fazer isso, ou indicar as fontes de recursos para custear esses direitos.

Interessante constatar, porém, o aparente paradoxo do desenvolvimento de interesses coletivos: ao mesmo tempo em que os grupos sociais passavam a ser formados por pessoas diferentes, sem a grande identificação apresentada antes (vide capítulo 1.2), a violação em massa desses interesses precisava ser combatida pelos lesados de forma coletiva, para que tivesse alguma eficácia. Assim, as mesmas conjunturas social e econômica que antes levaram à separação das pessoas pela diferenciação do seu modo de vida, mais tarde as conduziram à união para que pudessem defender os seus interesses.

Diversos fatores levaram a isso, com mais ou menos efetividade, conforme cada situação: a desproporção de forças entre o fornecedor de produtos ou serviços e o consumidor, cujas carências econômicas, técnicas e culturais obstam uma disputa equilibrada em juízo; a reduzida expressão econômica da lesão, insuficiente para representar uma compensação efetiva às despesas com o processo; a dispersão geográfica dos atingidos, muitas vezes impedidos de ter acesso à justiça. Tais fatores se apresentam, em consequência, como critérios de admissibilidade da defesa coletiva de interesses individuais, conforme será estudado com mais detalhes no capítulo 4.

Nessa mesma ordem de ideias, a sociedade moderna, mais do que revelar os interesses individuais homogêneos, determinou a sua proliferação, diferentemente do que aconteceu com os interesses difusos e coletivos stricto sensu. De fato, os interesses difusos e interesses coletivos, diversamente, já existiam na mesma intensidade muito antes da industrialização e do desenvolvimento tecnológico que criaram a produção em massa ${ }^{39}$.

\footnotetext{
${ }^{39}$ V. Nelson Nery Júnior (A ação civil pública no processo do trabalho. In: MILARÉ, Edis (coord.). Ação civil pública, lei 7.347/1985 - 15 anos. $2^{\mathrm{a}}$ ed. São Paulo: Editora Revista dos Tribunais, 2002).
} 
Mas faltava, antes, uma mentalidade social voltada à preocupação com a tutela dos interesses difusos, assim como a conformação dos interesses coletivos era muito diversa da que existe hoje. Esses interesses podiam não estar revelados ou podiam incidir em grupos humanos muito diferentes dos de hoje, mas já existiam na mesma proporção. Por exemplo: os danos ao meio ambiente, como a poluição de rios, a devastação de florestas ou a dizimação de espécies animais, são muito anteriores ao desenvolvimento das preocupações ecológicas (evidentemente por decorrência do avanço científico), ou seja, o conhecimento dos danos que isso pode provocar ao homem ou ao equilíbrio ambiental.

Da mesma forma, as antigas corporações de ofício, a nobreza ou o clero formavam grupos de pessoas que ostentavam inúmeros interesses indivisíveis. Márcio Flávio Mafra Leal menciona, com apoio em trabalho de Edward Peters (“A Critical Review", "The American Journal of Legal History", vol. XXXIV, 1990, p. 429), o caso de uma ação coletiva (ou o que mais se assemelhava a isso naquele tempo), possivelmente a mais antiga cujo relato chegou aos nossos dias, de 1179, por meio da qual os aldeões da vila de Rosny-sur-Bois postularam a extinção da condição de servos em face dos seus senhores, o abade e os clérigos de Santa Genoveva em Paris, França ${ }^{40}$. Consta que o processo durou décadas, exigiu o dispêndio de todos os recursos financeiros dos autores e acabou não chegando ao seu final, após a desistência de vários deles, por pressão dos réus, e da perda de objeto, finalmente, quando os aldeões compraram a sua liberdade.

Aloísio Gonçalves de Castro Mendes menciona outros casos na Inglaterra medieval: o de um pároco de Barkway que, em 1199, propôs ação perante a Corte Eclesiástica de Canterbury, visando o reconhecimento do direito a oferendas e serviços, contra os paroquianos de Nuthamstead, aparentemente considerados coletivamente; o de três aldeões que reivindicaram, em seu favor e de todos os habitantes do povoado de Helpingham, a condenação das comunidades das cidades de Donington e de Bykere na obrigação de assisti-los no conserto dos diques locais; e o de dois cidadãos de Scarborough que ajuizaram ação em seu favor e no de todos os burgueses pobres e médios da cidade, contra os burgueses ricos do lugar. $\mathrm{O}$ autor chega a sustentar, com base em estudo de Stephen Yeazell ("From medieval group litigation to the modern class action", New

\footnotetext{
${ }^{40}$ Ações Coletivas: história, teoria e prática. Porto Alegre: Sergio Antonio Fabris Editor, 1998, p. 21.
} 
Heaven: Yale University Press, 1987), que as ações de grupo tornaram-se frequentes nos séculos XIV e $\mathrm{XV}^{41}$.

Os interesses individuais homogêneos não. Eles não existiam, na prática, antes do surgimento da sociedade de massa; o que havia antes eram interesses comunitários e, depois, interesses individuais, tão-somente. Na Idade Média, nem sequer existia a noção de personalidade jurídica, de modo que não se colocava o problema da representação de direitos alheios: o membro da comunidade podia ser autor da ação coletiva não porque representasse os direitos dos demais interessados, mas porque defendia o direito da coletividade correspondente à sua comunidade, já que se tratava do interesse comum, e a comunidade podia estar em juízo e ser representada por qualquer de seus membros ${ }^{42}$.

Mesmo posteriormente, com o desenvolvimento das doutrinas individualistas e a elaboração de teorias da representação de direitos individuais por terceiros, os interesses individuais semelhantes que surgiam dificilmente decorriam de uma origem comum, pois não resultavam de relações de troca e de consumo de massa, padronizadas, como visto acima, as quais só começaram a difundir-se a partir do século XIX.

2.2 - Estímulos à litigiosidade

É inegável que o desenvolvimento da consciência sobre os direitos humanos de terceira geração, em nível internacional, bem como o despertar da consciência social e política derivada do processo de redemocratização e da promulgação da atual Constituição, em nível nacional, tenham um significado histórico da maior importância na luta pelo acesso à justiça e pela igualdade de direitos. Nesse sentido, a contribuição trazida

\footnotetext{
${ }^{41}$ Ações coletivas: no direito comparado e nacional. São Paulo: Editora Revista dos Tribunais, 2002, p. 4344.

${ }^{42}$ V. Márcio Flávio Mafra Leal, Ações Coletivas: história, teoria e prática. Porto Alegre: Sergio Antonio Fabris Editor, 1998, p. 24.
} 
por esses movimentos à tendência recente de aumento da litigiosidade na sociedade brasileira representa, naturalmente, um aspecto positivo ${ }^{43}$.

Por outro lado, é também evidente que a enorme esperança de acesso à justiça trazida por esse quadro social impõe igualmente um mínimo de efetividade, para não ficar completamente frustrada. Sob esse ponto de vista, é necessário questionar se esse estado de coisas não estaria propiciando um excesso de estímulos à litigiosidade o qual, longe de conferir meios de tutela de direitos fundamentais a quem nunca teve acesso à ordem jurídica, contribui apenas para congestionar e inviabilizar o Poder Judiciário como instrumento de garantia popular da cidadania ${ }^{44}$.

Antes de tudo, é importante ponderar que, numa sociedade moderna, ou seja, geralmente numerosa, complexa e diversificada, a quantidade potencial de conflitos é muito grande e constitui irracionalidade canalizar todos eles ao Poder Judiciário. Naturalmente cercado de formalismos e grande ênfase na garantia de ampla oportunidade de participação dos interessados, o procedimento judiciário implica, por sua própria natureza, um rito caro e demorado.

Sociedade nenhuma, muito menos em países pobres, pode dar-se ao luxo de pretender resolver todos os litígios, ou mesmo a maioria deles, no âmbito de um processo judicial $^{45}$. Além do mais, nem sequer haveria grande vantagem nisso, ainda que fosse possível, considerando que o mesmo poder de império que impõe às partes a solução dada pelo Estado-juiz pode também ser conferido a outras formas de composição de divergências; da mesma forma, não há qualquer comprovação científica de que a solução

\footnotetext{
${ }^{43}$ Sem esquecer, evidentemente, de outras modificações sofridas pela sociedade brasileira nas últimas décadas, as quais também contribuíram para o aumento da demanda por justiça, como a urbanização e a industrialização (Poder Judiciário: Perspectivas de Reforma. Opinião Pública, Campinas, vol. X, n. 1, maio de 2004, p. 11. Disponível em <http://www.scielo.br/pdf/op/v10n1/20314.pdf>. Acesso em 25/05/2008).

${ }^{44}$ De 1990 a 2002, diante de um crescimento de 20,7\% na população brasileira, houve um aumento de quase $170 \%$ no número de processos judiciais distribuídos na Justiça Comum no país, segundo dados do IBGE e do Banco Nacional de Dados do Poder Judiciário. No mesmo período, o Supremo Tribunal Federal experimentou um aumento de espantosos $764 \%$ nos processos protocolados, de acordo com dados do próprio tribunal (Maria Teresa Sadek, Poder Judiciário: Perspectivas de Reforma. Opinião Pública, Campinas, vol. X, n. 1, maio de 2004, p. 13. Disponível em <http://www.scielo.br/pdf/op/v10n1/20314.pdf〉. Acesso em 25/05/2008).

${ }^{45}$ O governo brasileiro, conforme relatório oficial, gasta 3,66\% do seu orçamento com o sistema judiciário, parcela mais alta dentre 35 países incluídos em estudo do Banco Mundial (Diagnóstico do Poder Judiciário. Brasília: Secretaria Especial de Reforma do Judiciário, agosto de 2004, p. 74. Disponível em <http://www.direitos.org.br/index.php?option=com_remository\&Itemid=99\&func=fileinfo\&id=156>. Acesso em 10/10/2008).
} 
encontrada mediante um processo judicial mereça maior resignação por parte dos vencidos do que aquela verificada em procedimentos extrajudiciais ${ }^{46}$.

Assim sendo, o processo judicial deveria ser reservado àquelas hipóteses nas quais são inviáveis outros meios de composição de lides, seja pela hipossuficiência econômica dos interessados, seja pela indisponibilidade dos interesses em disputa. Porém, não é isso que se observa.

O Brasil tem muito pouca disponibilidade de dados confiáveis que permitam estudos científicos que possam ir além das presunções. Na atividade judiciária, só recentemente, com as discussões que levaram à reforma do Poder Judiciário (EC n. 45, de 08 de dezembro de 2004), alguns dados começaram a ser levantados. A partir deles, alguns estudos têm apontado que o aumento do acesso à justiça tem sido relativo.

Isso porque a ampliação do número de processos ajuizados não tem correspondido a uma ampliação semelhante no número de demandantes, por pelo menos duas razões: em primeiro lugar, porque o Poder Público segue sendo o maior demandante do país, ainda mais se consideradas a administração direta e indireta ${ }^{47}$; em segundo lugar, porque a facilitação de acesso à justiça tem funcionado mais para estimular aqueles que já tinham acesso ao Poder Judiciário a propor mais demandas, do que para atrair a multidão de marginalizados dos serviços judiciais, seja porque aqueles já têm à sua disposição os meios básicos para isso (consciência dos seus direitos, acesso a advogados etc.), seja porque já avaliaram positivamente os benefícios que terão com o litígio, ainda que não estejam convencidos do direito a pleitear, sempre que a demora do processo lhes seja favorável, como é o caso de quem deve alguma espécie de prestação ${ }^{48}$.

\footnotetext{
${ }^{46}$ A difusão de métodos alternativos de solução de controvérsia constitui recomendação da ONU a todos os estados-membros, por meio da Resolução n. 1999/26, de 28 de julho de 1999. A propósito, v. Acesso à Justiça por Sistemas Alternativos de Administração de Conflitos - Mapeamento nacional de programas públicos e não governamentais. Brasília: Secretaria Especial de Reforma do Judiciário, 2005. Disponível em <http://www.direitos.org.br/index.php?option=com_remository\&Itemid=99\&func=fileinfo\&id=259>. Acesso em 18/11/2008.

${ }^{47}$ No ano de 2003, a União, o INSS e a Caixa Econômica Federal figuraram como réus em 2.623.679 ações, número equivalente a 1,5\% da população brasileira, conforme Rogério Pacheco Alves (As prerrogativas da administração pública nas ações coletivas. Dissertação de Mestrado em Sociologia e Direito da Universidade Federal Fluminense. $\quad$ Rio de Janeiro, $2005 . \quad$ Disponível $\quad$ em <http://www.uff.br/ppgsd/Dissertacoes/rogerio2005.pdf>. Acesso em 19/05/2008).

${ }^{48}$ V. Maria Teresa Sadek, que fala no paradoxo das "demandas de menos e demandas de mais": "de um lado, expressivos setores da população acham-se marginalizados dos serviços judiciais, utilizando-se, cada vez mais, da justiça paralela, governada pela lei do mais forte, certamente muito menos justa e com altíssima
} 
Ainda mais grave: esses litigantes, muitas vezes, utilizam-se dos serviços judiciários para discutir matérias que nem mesmo deveriam ser trazidas a juízo, transformando o Poder Judiciário em instrumento de coação e mesmo de sanção ${ }^{49}$. Isso leva a juízo litígios precariamente configurados, tanto por comportarem composição extrajudicial como também por não exibirem uma resistência efetiva por parte do demandado 50 .

\section{3 - Métodos alternativos de solução de controvérsias}

Parte do problema causado pelos estímulos à litigiosidade poderia ser resolvido pela utilização mais ampla de meios extrajudiciais de composição de lides, dentre os quais se destacam a conciliação, a mediação e a arbitragem ${ }^{51}$. A análise das características desses métodos refoge aos objetivos desse trabalho, merece atenção, porém, a avaliação dos motivos pelos quais não têm eles conseguido impor-se como opção interessante aos litigantes.

As dificuldades de disseminação desses métodos alternativos começam nos antigos costumes formalistas e estatistas da sociedade brasileira. Herdeira de métodos e procedimentos da antiga monarquia absolutista portuguesa, que lutava pela centralização

potencialidade de desfazer todo o tecido social. De outro, há os que usufruem em excesso da justiça oficial, gozando das vantagens de uma máquina lenta, atravancada e burocratizada" (Poder Judiciário: Perspectivas de Reforma. Opinião Pública, Campinas, vol. X, n. 1, maio de 2004, p. 12. Disponível em <http://www.scielo.br/pdf/op/v10n1/20314.pdf>. Acesso em 25/05/2008).

${ }^{49}$ Para o Ministro Enrique Ricardo Lewandowski, do STF (Supremo Tribunal Federal), o brasileiro adquiriu a cultura dos Estados Unidos que leva à justiça "qualquer caso de briga de vizinhos". "É preciso mudar essa cultura de exacerbada litigiosidade forense importada dos americanos. Briguinhas que poderiam ser resolvidas logo vão parar na Justiça. Em outros países, as instâncias devem ser esgotadas antes que o pleito seja levado à mais alta instância do poder judiciário". (Boletim de Notícias da página do Instituto de Mediação e Arbitragem do Estado de São Paulo. Disponível em <http://www.imaesp.com.br>. Acesso em 21/05/2008)

${ }^{50}$ Misael Montenegro Filho aponta, como uma das causas pelas quais o processo não vem alcançando suas finalidades, "a arte de litigar, própria do povo latino, determinando que pequenos queixumes e minúsculas reclamações do cotidiano se misturem a casos de inegável repercussão jurídica, sem que se separe o joio do trigo, como nos ensina o adágio popular" (Importância da ação civil pública no panorama da abarrotada justiça brasileira: vicissitudes e perigos da ação em estudo. In: MAZZEI, Rodrigo; NOLASCO, Rita (coord.). Processo civil coletivo. São Paulo: Quartier Latin, 2005, p. 173).

${ }^{51}$ A classificação dos meios extrajudiciais de solução de controvérsias, também conhecidos pela sigla ADR (do inglês "Alternative Dispute Resolution"), em autocompositivos e heterocompositivos, conforme sejam promovidos pelas próprias partes ou com interveniência de terceiros - ainda que didática, está longe de ser absoluta, porque algumas modalidades, como a conciliação, reúnem características de ambas as categorias. Nesse sentido, Roque Komatsu (A tentativa de conciliação no processo civil. Dissertação de Mestrado em Direito da Universidade de São Paulo. São Paulo, 1978, p. 71). 
do poder nas mãos dos representantes da Coroa, os brasileiros filiaram-se a uma longa tradição portuguesa de submeter todas as disputas ao Estado-juiz, detentor do monopólio do poder de dizer o direito ${ }^{52}$. Essa antiga tradição dificulta a aceitação de submeter a particulares a decisão sobre um litígio e, ainda mais, de partir para uma solução de autocomposição (conciliação ou mediação).

As vantagens ilegítimas obtidas pelos litigantes contumazes ou "profissionais" representam também impedimento à utilização de meios alternativos de resolução de controvérsias. Se a morosidade do processo estatal representar um benefício para uma das partes, na medida em que uma delas estiver obtendo vantagem com a situação atual e os mecanismos antecipatórios de tutela forem inefetivos ${ }^{53}$, naturalmente ela não terá qualquer estímulo a procurar alternativas que possam produzir uma solução mais rápida. A situação constitui um claro círculo vicioso, porque quanto mais lento é o processo judicial, mais os litigantes contumazes o procuram, já que isso atende aos seus interesses; quanto mais os litigantes contumazes procuram o processo judicial, mais o tornam congestionado e, em decorrência, lento, considerando que, na média, esses litigantes estão envolvidos numa quantidade de processos bem maior do que os demais destinatários da tutela jurisdicional.

Outro obstáculo é o desconhecimento decorrente da falta de tradição dos meios alternativos de composição de litígios. A utilização desses métodos, por possuírem pouca penetração social entre nós e terem começado a ser mais divulgados recentemente, é cercada de preconceitos, sobretudo concernentes à sua efetividade e custos.

Desconfia-se de procedimentos sem a força cogente do Estado, representado pelo Poder Judiciário, de modo que o vitorioso não possa valer-se de uma decisão favorável; imagina-se que procedimentos com intervenção de particulares, sem subvenção estatal, sejam muito caros. A disseminação da arbitragem como método preferido por algumas empresas de grande porte acaba por acentuar o preconceito de que, fora do âmbito estatal, resolver litígios é muito dispendioso. Trata-se de outro círculo

52 Sobre as particularidades do absolutismo português, v. José Hermano Saraiva (História concisa de Portugal. $18^{\mathrm{a}}$ ed. Mem Martins Codex: Europa-América, 1996, p. 225); sobre o modo como o poder da coroa alcançava a colônia distante, v. Boris Fausto (História do Brasil. $2^{a}$ ed. São Paulo: EDUSP, 1995, p. 62).

${ }^{53}$ Cf. Fernando da Fonseca Gajardoni, Técnicas de aceleração do processo. São Paulo: Lemos \& Cruz, 2003, p. 162. O autor sustenta que a tutela antecipada "uma vez concedida, representará, por si só, grande incentivo a autocomposição bilateral". 
vicioso porque quanto menor é a utilização dos meios alternativos, maior é o desconhecimento e a convicção a respeito da sua inconveniência e quanto mais amplo é o desconhecimento e o juízo desfavorável, menores serão as possibilidades de popularização.

Todos esses obstáculos, naturalmente, devem ser enfrentados com informação, divulgação e mudança de mentalidade, processo no qual a participação do Estado é fundamental, tanto para afiançar a efetividade desses métodos, quando bem utilizados, como para assegurar uma divulgação ampla e geral. De qualquer maneira, ainda que haja esse engajamento governamental, não parece ser um processo capaz de produzir resultados rápidos, infelizmente ${ }^{54}$.

\section{4 - Jurisdição singular e Poder Judiciário}

\subsection{1 - A Cultura jurídico-processual individualista}

A lide singular, confrontando titulares de direitos divisíveis, legada do Direito Romano $^{55}$, constitui o modelo de litígio dominante não apenas das pautas do Poder Judiciário, mas também das mentes dos operadores do Direito. A jurisdição coletiva, não obstante suas evidentes e inegáveis vantagens para resolver litígios de massa ${ }^{56}$, ainda se encontra longe de apresentar familiaridade aos operadores do Direito.

\footnotetext{
54 Existe já um esforço para catalogar e caracterizar as iniciativas dispersas de difusão dos métodos alternativos de resolução de controvérsias no Brasil, visando a formulação de uma política que coordene essas ações, mas isso só confirma o longo caminho que ainda precisará ser percorrido para atingir o objetivo de popularizar a sua utilização. Segundo Jacqueline Sinhoretto, consultora de projeto nesse sentido no âmbito da Secretaria de Reforma do Judiciário do Ministério da Justiça, "o investimento social em sistemas alternativos de gestão do conflito é interessante, não como substituto do direito fundamental de acesso à Justiça pública, mas como mecanismo complementar que pode ajudar a, cada vez mais, produzir espaços em que a gestão social de interesses antagônicos se faça com base no direito, no respeito aos direitos fundamentais, desvalorizando assim as formas violentas e opressivas de resolução de disputas, sempre tão presentes na sociedade brasileira. Os primeiros passos na construção dessas alternativas já estão sendo dados. Não se trata mais de partir do zero, pois o Brasil já acumula alguma experiência nesse campo, embora, para bem ou para mal, não exista ainda uma tradição e tampouco um perfil claro sobre o que fazer ou como fazer para se alcançar os objetivos há pouco mencionados" (Acesso à Justiça por Sistemas Alternativos de Administração de Conflitos - Mapeamento nacional de programas públicos e não governamentais. Brasília: Secretaria Especial de Reforma do Judiciário, 2005. Disponível em <http://www.direitos.org.br/index.php?option=com_remository\&Itemid=99\&func=fileinfo\&id=259> . Acesso em 18/11/2008).

${ }^{55} \mathrm{~V}$. capítulo 1.1 .

${ }^{56}$ Para Rodolfo de Camargo Mancuso, o processo coletivo apresenta como vantagens "(i) resposta isonômica aos sujeitos concernentes ao conflito"; "(ii) prevenção do fracionamento do conflito coletivo em demandas múltiplas e repetidas"; "(iii) otimização da eficácia da resposta judiciária"; "(iv) aumento da credibilidade social na função jurisdicional"; "(v) erradicação dos possíveis resíduos conflitivos periféricos"; e "(vi)
} 
São comuns os equívocos de conceituação, sendo mais graves, naturalmente quando cometidos pelos juízes (já que, muitas vezes, a correção acaba dependendo da interposição de um recurso, não de uma simples retificação): ações coletivas propostas como ações individuais, com pedido específico e a juntada de inúmeros documentos de cada interessado já identificado; ações individuais propostas como coletivas, por entes não legitimados à tutela coletiva e sem a demonstração de anuência dos interessados; interesses individuais homogêneos confundidos com interesses coletivos; entre outros.

Além disso, a falta de especialização dos juízos, e mesmo dos escritórios, contribui para o aprofundamento dessas dificuldades, porque o processo coletivo acaba sendo tratado da mesma forma que os individuais, sem preocupação com as adaptações necessárias para responder às exigências que decorrem das peculiaridades da jurisdição coletiva. As dificuldades começam com a lentidão na tramitação dos processos, problema crucial enfrentado pelo Poder Judiciário na atualidade, diante das cobranças da sociedade por um processo mais célere, que invariavelmente são debitadas na conta da oferta de serviços judiciários, olvidando-se quase completamente o lado da demanda por esses serviços ${ }^{57}$. Por essa razão, qualquer fonte de demora na tramitação processual que retarde a prolação da sentença constitui razão suficiente para incutir no juiz, e mesmo nos auxiliares do juízo, certa aversão contra o procedimento submetido a essa contingência.

Ocorre que o problema ganha dimensões mais dramáticas no processamento das ações coletivas, a começar da necessidade mais frequente de interrupção da tramitação processual, decorrente de diversas vicissitudes próprias da tutela coletiva, na qual o autor representa uma coletividade titular dos interesses em disputa. Natural que, nessa situação, muito além do que costuma ocorrer na jurisdição singular,

consecução do ideal de pacificação dos conflitos" com "uma resposta judiciária de qualidade", isto é, "justa, jurídica, econômica, tempestiva e razoavelmente previsivel" (Jurisdição coletiva e coisa julgada. São Paulo: Editora Revista dos Tribunais, 2007, p. 209).

${ }^{57}$ Algumas sugestões para o aperfeiçoamento do processo coletivo, de grande utilidade teórica mas de difícil aplicação prática, precisam ser analisadas dentro desse contexto, como a introdução do amicus curiae e a realização de audiências públicas" (v. Américo Bedê Freire Júnior, Os poderes do juiz nas ações coletivas e breves sugestões de lege ferenda ao aprimoramento do processo coletivo. In: Revista de Processo n. 117, São Paulo, Editora Revista dos Tribunais, set./out. 2004, p. 129/134). 
ocorram intromissões e extromissões no processo (v.g. admissão de litisconsortes ${ }^{58}$ ), as quais implicam sobrestamentos e, portanto, atrasos no andamento processual.

As despesas processuais também acarretam demora na tramitação processual. Seja no momento da publicação de editais para conhecimento de eventuais interessados, seja no momento de produção de prova, especialmente pericial, a dificuldade do autor em suportar as despesas daí decorrentes pode levar a uma paralisação do feito coletivo $^{59}$.

Outra fonte de grandes dificuldades é a necessidade de adaptação para tratar de temas próprios da tutela coletiva, ao mesmo tempo, de grande repercussão e de complexa solução. Todos os envolvidos, e especialmente o juiz, terão de se comportar com muita serenidade para enfrentar pressões de toda ordem (dos interessados, da imprensa, da opinião pública etc.) e para trabalhar com um grau de criatividade com o qual não estão acostumados e para o qual não foram preparados. Por exemplo, diante de um pedido de fechamento de um aeroporto em decorrência do risco de acidentes, não basta simplesmente julgar improcedente o pedido, ainda que o autor não tenha direito a esse provimento; é preciso verificar se outras medidas são indicadas pelas informações constantes dos autos ou recomendadas pelos interesses que o autor visa tutelar, como o fechamento após o acúmulo de uma determinada lâmina de água na pista de pouso, a partir da qual a operação deixa de ser segura, conforme demonstrado nos autos. Provimento semelhante pode ser considerado um julgamento de procedência parcial, de maneira a impor ao juiz a obrigação de examiná-lo, ainda que não tenha sido previsto ou sequer cogitado pelas partes, como é comum acontecer ${ }^{60}$.

Nesse particular, é comum encontrar petições em ações coletivas nas quais os autores gastam todas as suas energias na fundamentação dos pedidos, esquecendo-

\footnotetext{
${ }^{58}$ Art. 94 do Código de Defesa do Consumidor.

${ }^{59}$ Sobre o impasse a que isso pode levar o processo, v. Vladimir Passos de Freitas, A perícia como requisito da administração da justiça $\quad$ ambiental. $\quad$ Disponível $\quad$ em <http://www.abdir.com.br/doutrina/ver.asp?art_id=\&categoria=Tutela Processual ambiental>. Acesso em $10 / 12 / 2008$.

${ }^{60}$ Nesse sentido, Américo Bedê Freire Júnior (Os poderes do juiz nas ações coletivas e breves sugestões de lege ferenda ao aprimoramento do processo coletivo. In: Revista de Processo n. 117, São Paulo, Editora Revista dos Tribunais, set./out. 2004, p. 129/134), não apenas cogitando essa possibilidade mas também defendendo “...uma mitigação ao princípio da correlação entre o pedido e a sentença, para fornecer ao juiz a maleabilidade necessária para produzir uma solução materialmente adequada à lide posta em suas mãos.".
} 
se da importância na formulação criteriosa dos próprios pedidos. Até como forma de auxiliar e orientar o juiz na busca da tutela necessária e suficiente para atender às necessidades dos interessados, o desenvolvimento dos pedidos nas ações coletivas deveria merecer pelo menos tanta atenção quanto a fundamentação, se for o caso com minucioso detalhamento e extenso desdobramento, incluindo pedidos aditivos, alternativos e subsidiários.

Também representa grande dificuldade para o juiz a necessidade de examinar questões que impliquem o controle de decisões de conteúdo administrativo do Poder Executivo. Como é cediço, tendo em vista o princípio da separação dos poderes, é descabida a revisão de decisão administrativa tomada no âmbito do poder discricionário, mas possível se tal decisão tiver ultrapassado esses limites. Ocorre que não é fácil definir essa linha divisória, de modo que as consequências de uma decisão em sede de tutela coletiva nesse caso, invariavelmente, são extremamente graves, envolvendo expressivos valores econômicos e atingindo grande número de pessoas.

A dificuldade consiste no fato de que o juiz precisa decidir se as motivações da escolha administrativa estão conformes ao ordenamento jurídico com base em informações muito mais precárias do que aquelas disponíveis para o administrador público, geralmente cercado de assessoria técnica e dispondo de muito mais tempo para decidir. Do juiz são requeridas decisões liminares, sem oitiva da parte contrária, justas, jurídicas e imediatas, bem como sentenças igualmente rápidas e precisas, não importa o volume de trabalho ao qual esteja submetido. A produção de prova pericial, única circunstância na qual o juiz conta com auxílio técnico para decidir, depende de viabilidade econômica e tem momento certo para ocorrer, muito depois que graves decisões sejam requeridas pelas partes.

É o caso da ação civil pública que venha exercer o controle difuso da constitucionalidade das leis (v.g., a propositura de ação civil pública visando à reposição de expurgos inflacionários sobre a correção monetária de ativos financeiros determinados por lei ${ }^{61}$ ), bem como da utilização da tutela coletiva para o controle de políticas públicas

\footnotetext{
${ }^{61}$ Supremo Tribunal Federal, Reclamação n. 600/SP, Relator Min. Néri da Silveira, DJ de 05/12/2003, p. 19.
} 
(v.g, a propositura de ação civil pública para obtenção de ampliação e melhoria do atendimento de gestantes em hospitais públicos ${ }^{62}$ ).

A ser considerada também certa aversão à tutela coletiva por parte da advocacia, por razões econômicas, decorrente da natural redução de causas provocada pela "molecularização das demandas",63, conduzindo a uma inevitável redução do mercado de trabalho ${ }^{64}$. Não se está aqui fazendo qualquer juízo de mérito sobre a legitimidade desse tipo de posicionamento. $\mathrm{Na}$ condição de trabalhadores especializados e na perspectiva de profissionais liberais que são, os advogados encontram-se alheios ao problema da crise do Poder Judiciário e do acúmulo de processos, salvo nas questões que lhes possam afetar pessoalmente (v.g., a demora dos processos que patrocinam).

Como operadores do Direito, juristas ou mesmo cidadãos com conhecimento do assunto, podem ter opinião pessoal favorável à maior utilização do processo coletivo para reduzir a morosidade da jurisdição estatal, mas não estão obrigados a agir de acordo com essa convicção ou mesmo a se preocupar com o assunto. Tanto isso é verdade que, exatamente da mesma forma, a sociedade em geral até pode preocupar-se com a questão da quantidade de cursos de Direito e de formandos em busca de trabalho, mas não tem nenhum compromisso em assegurar mercado profissional, nem mesmo para os advogados já formados, muito menos para os que ainda se formarão nos anos vindouros, se isso não estiver de acordo com o interesse social geral de permitir amplo acesso à justiça.

Sendo assim, é natural que a grande maioria dos advogados desconheça por completo a jurisdição coletiva, seus problemas, vantagens e desvantagens, excluídos os ligados a associações ou organizações não-governamentais. De fato, é muito comum

${ }^{62}$ Superior Tribunal de Justiça, Recurso Especial n. 744592/AM, Primeira Turma, Relatora Min. Denise Arruda, decisão de27/11/2007.

${ }^{63}$ Expressão cunhada por Kazuo Watanabe (Demandas coletivas e os problemas emergentes da práxis forense. In: Revista de Processo n. 67, São Paulo, Editora Revista dos Tribunais, jul./set. 1992, p. 23).

${ }^{64}$ Para Francisco Cesar Pinheiro Rodrigues, Desembargador aposentado do TJ-SP, "a legislação constitucional e infra-constitucional outorgou inúmeros direitos. Bom, em tese. No entanto, para cada avanço processual - ótimo para a coletividade - havia um prejuízo implícito para o advogado, visto como um profissional que vive de seu trabalho. Para cada 'ação civil pública' bem-sucedida há a dispensa de centenas ou de milhares de ações individuais. O mesmo ocorre com os mandados de segurança coletivos. Idem, nas ações diretas de inconstitucionalidade e nas diretas de constitucionalidade. Um só julgamento dispensa milhares de ações movidas individualmente" (Progressos profissionais que se voltam contra os profissionais. Disponível em <http://www.amb.com.br/?secao=artigo_detalhe\&art_id=660\&>. Acesso em $12 / 08 / 2008)$. 
encontrar advogados, mesmo experientes, que jamais ajuizaram ou sequer atuaram em uma ação civil pública.

Para agravar ainda mais o problema, em muitos casos as cortes têm considerado que o Ministério Público usurpa as funções do advogado ao assumir a tutela judicial, mediante ação coletiva, de interesses individuais disponíveis ou heterogêneos. São exemplos as ações civis públicas visando impedir a majoração da carga tributária ${ }^{65}$ e aquelas para defender interesses individuais específicos de menores, respectivamente ${ }^{66}$.

\subsection{2 - A estrutura judiciária e o acúmulo de processos}

Assunto recorrente nas discussões que cercam as reformas processuais, há mais de dez anos, é a chamada Crise do Judiciário, a percepção difundida pela sociedade de que o Poder Judiciário não vem atendendo sua principal finalidade, isto é, a pacificação social por meio do processo jurisdicional, que vem apresentando-se complexo, burocrático e lento $^{67}$. Não é difícil concluir que, se a prestação do serviço jurisdicional deixou de atender aos reclamos da sociedade sem que tenha havido redução na oferta, é porque a demanda aumentou o suficiente para levar ao colapso a estrutura instalada ${ }^{68}$. É evidente que isso não significa que a máquina judiciária não possua defeitos, muito pelo contrário, mas é preciso ter em mente que os recursos para melhorar a estrutura a fim de

${ }^{65}$ V. RE-AgR n. 559985/DF, DJe-018 de 31/01/2008, Relator Min. Eros Grau; ERESP n. 505303/SC, Primeira Seção, decisão de 11/06/2008, DJE de 18/08/2008, Relator Min. Humberto Martins; RESP 902729/DF, Primeira Turma, decisão de 18/03/2008, DJE de 28/04/2008, Relatora Min. Denise Arruda.

${ }^{66}$ V. REsp. n. 488427/SP, Segunda Turma, decisão de 21/06/2007, DJ de 06/08/2007, p. 471, Relatora Min. Eliana Calmon; Recurso Especial - 718393/RS, Segunda Turma, decisão de 18/08/2005, DJ de 20/03/2006, p. 245, Relator Min. Franciulli Netto; REsp n. 683705, Primeira Turma, decisão de 27/09/2005, DJ de 21/11/2005, p. 138, Relator Min. Francisco Falcão. Não obstante, o Ministério Público de São Paulo tem posição institucional favorável à possibilidade do ajuizamento de ação civil pública, ainda que em favor de uma única pessoa, visando o fornecimento de tratamento médico ou de medicamentos pelo poder público (Súmula do Conselho Superior n. 45).

${ }^{67}$ Foram consequências dessa crise as inovações constitucionais introduzidas pela Emenda n. 45/2004, conhecida por Reforma do Judiciário, dentre as quais se destacam a criação de um órgão externo de controle do Poder Judiciário, o Conselho Nacional de Justiça, a criação da Secretaria de Reforma do Judiciário do Ministério da Justiça e as diversas reformas legislativas no processo civil e, mais recentemente, penal.

${ }^{68} \mathrm{~V}$. item 2.2, especialmente nota 44. 
readequá-la são escassos, assim como são limitadas as possibilidades de melhorar a eficiência mediante reformas racionalizadoras dos procedimentos ${ }^{69}$.

Foge do escopo deste trabalho, porém, analisar os fatores que têm prejudicado a eficiência do serviço jurisdicional e provocado a insatisfação social com o Poder Judiciário. O objetivo deste tópico é tão-somente demonstrar a função que exerce nessa problemática a proliferação de causas repetidas e o potencial que a tutela dos interesses individuais homogêneos mostra, com a sua natural vocação para aglutinar litígios semelhantes, para desempenhar um papel fundamental na busca de uma solução ${ }^{70}$.

Com efeito, o afogamento do Poder Judiciário, no qual a propositura de demandas repetidas desempenha importante papel, é circunstância por demais conhecida. Os episódios de ajuizamento em massa de ações idênticas decorrentes de medidas governamentais nas décadas de 80 e 90 apresentam reflexos até hoje ${ }^{71}$. Como consequência, não é incomum a prolação de sentenças repetidas pelos órgãos judiciais, mediante reprodução automatizada, via recursos de informática, em centenas ou milhares de processos semelhantes escolhidos mediante triagem feita por funcionários do Poder Judiciário. A própria elaboração da sentença acaba sendo feita por assessores, sob supervisão judicial, uma vez que o texto, único, redigido pelo juiz (sem que seja afrontado o art. 164 do Código de Processo Civil ${ }^{72}$ ), apenas será reproduzido em todos aqueles feitos, com a adaptação dos dados processuais e nomes das partes sendo feita pelos recursos dos editores de texto para "mala direta", exatamente como fazem as empresas comerciais quando querem atingir grande contingente de potenciais clientes com as suas propagandas. Quanto à assinatura do juiz, é lançada “em lote”, por meio eletrônico.

\footnotetext{
${ }^{69}$ Afinal, as reformas atuam para reduzir o tempo de tramitação dos processos, encontrando limite no tempo em que os autos se encontram com as partes, com o juiz ou com os auxiliares do juízo (peritos, contadoria etc.), que é considerável.

${ }^{70}$ Nesse sentido, v. Misael Montenegro Filho (Importância da ação civil pública no panorama da abarrotada justiça brasileira: vicissitudes e perigos da ação em estudo. In: MAZZEI, Rodrigo; NOLASCO, Rita (coord.). Processo civil coletivo. São Paulo: Quartier Latin, 2005, p. 174-176).

${ }^{71}$ No final de 2008, nova enxurrada de ações foi ajuizada na Justiça Federal em decorrência do iminente término do prazo prescricional para pleitear eventual perda da correção monetária das cadernetas de poupança em virtude do chamado "plano verão", de janeiro de 1989, durante o Governo José Sarney (Prazo para revisão da caderneta de poupança está no fim. Disponível em <http://www1.folha.uol.com.br/folha/dinheiro/ult91u480413.shtml>. Acesso em 20/12/2008).

72 “Os despachos, decisões, sentenças e acórdãos serão redigidos, datados e assinados pelos juízes. Quando forem proferidos, verbalmente, o taquígrafo ou o datilógrafo os registrará, submetendo-os aos juízes para revisão e assinatura".
} 
Tais decisões padronizadas são repassadas por meio de arquivos de editores de texto em disquetes ou, mais modernamente, nas páginas dos órgãos judiciários na Internet, para que outros juízes as adotem como modelos, adaptando-os às suas necessidades. Tal postura é amplamente estimulada pelos tribunais, que organizam repositórios de modelos de sentenças, especialmente as chamadas repetitivas por causa da sua enorme incidência e por envolverem, de modo geral, exclusivamente matérias de direito já pacificadas na jurisprudência

Mas nem isso é suficiente. O volume de processos é tão avassalador e predominantemente produzido em surtos que invariavelmente provoca acúmulo exagerado de processos em setores ou órgãos específicos, os quais vão sucedendo-se. Primeiro são os serviços de distribuição, que ficam atolados pelo volume de petições; depois as secretarias dos órgãos para onde foram feitas as distribuições, para formalizar a tramitação processual (juntadas, registros etc.); depois os gabinetes do juízes, para fazer a triagem e analisar os pedidos; depois novamente as secretarias, para executar os provimentos (expedição de ofícios, mandados etc.), e assim por diante. Para impedir o caos no serviço, organizam-se mutirões, convocando-se juízes e servidores de outros órgãos para auxiliar nos mais afetados, com prejuízo do serviço nos órgãos de origem, evidentemente.

Não é que esse tipo de providência seja descabido. Com certeza, pior ainda seria que os juízes elaborassem integralmente sentença original para cada um desses casos ou que se permitisse a paralisação dos serviços em setores que tivessem recebido serviço muito além da sua capacidade, porque aí então é que a inviabilização do funcionamento do Poder Judiciário seria completa. O retrato dessa situação, porém, que já começa a ser chamada de "justiça de assessoria", "justiça de disquete" ou "justiça de mutirão", mostra bem que é inaceitável continuar nesse estado de coisas, porque não é essa a relevante função a ser desempenhada pelo Poder Judiciário. A estrutura judiciária é qualificada, especializada e cara demais para ser desperdiçada com a solução de litígios que jamais deveriam ter sido levados a juízo, porque apresentam todas as condições para serem resolvidos por outros meios muito mais apropriados para uma solução compartilhada, uniforme e célere, a começar pelo procedimento administrativo, que deve ser aperfeiçoado e prestigiado.

Essa situação de abarrotamento dos órgãos judiciários provoca outro efeito perverso, ou seja, a impossibilidade prática do exercício pleno dos poderes 
conciliatórios do juiz, de acordo com a previsão legal do art. 125 do Código de Processo Civil, in verbis:

“Art. 125. O juiz dirigirá o processo conforme as disposições deste Código, competindo-lhe:

\section{(...) \\ IV - tentar, a qualquer tempo, conciliar as partes.”}

Diante do volume invencível de processos e da predisposição litigiosa das partes, que ajuizaram a ação acreditando que a sentença lhes trará benefício maior do que um acordo pré-processual com o oponente, a tentativa de conciliação judicial acaba transformando-se numa atividade burocrática só realizada para cumprir a lei, sem uma dedicação efetiva. Segundo Kazuo Watanabe, a própria audiência preliminar do art. 331 do Código de Processo Civil, iniciativa legislativa que visava atribuir ao juiz uma conduta mais eficaz na busca de soluções para o litígio, conciliatórias ou não, acabou por esvaziarse, diante da falta de interesse das partes e de empenho do juiz. O autor lamenta que os juízes prefiram proferir sentenças em vez de tentar conciliar as partes, às vezes deixando de realizar a audiência preliminar, cuja inspiração, lembra, foi o "modelo de Stuttgart de audiência no processo civil " ${ }^{, 73}$. E tem toda a razão, pois a audiência preliminar é o momento certo para uma tentativa de conciliação nas causas em que não existe uma efetiva resistência à pretensão da parte contrária, apenas falta de diálogo entre as partes, o que esse contato em juízo pode ensejar.

Porém, é preciso decidir se convém criar a indispensável estrutura para comportar a transposição, para cá, do modelo que lá fora deu certo, lembrando que exatamente a Alemanha é exemplo sempre citado de Poder Judiciário ágil porque bem aparelhado, dispondo de um juiz para cada 3.500 habitantes, enquanto no Brasil há um juiz para quase 13.000 habitantes $^{74}$; enquanto naquele país europeu cada juiz não preside mais de 400 processos simultaneamente, aqui a média ultrapassa 2.000 processos $^{75}$. Talvez as

\footnotetext{
${ }^{73}$ Cultura da sentença e cultura da pacificação. In: YARSHELL, Flavio Luiz; MORAES, Maurício Zanoide. Estudos em homenagem à professora Ada Pellegrini Grinover. São Paulo: DPJ Editora, 2005, p. 687.

${ }^{74}$ Diagnóstico do Poder Judiciário. Brasília: Secretaria Especial de Reforma do Judiciário, agosto de 2004, p. 68.

<http://www.direitos.org.br/index.php?option=com_remository\&Itemid=99\&func=fileinfo\&id=156>. Acesso em 10/10/2008.

${ }^{75}$ Mais precisamente, 2.349 processos na Justiça Federal e 4.771 processos na Justiça Estadual, de acordo com dados levantados pelo próprio Poder Judiciário (Justiça em números - Indicadores estatísticos do Poder
} 
soluções importadas exijam uma adaptação mais realista, considerando que montar aqui uma estrutura compatível com a que existe no lugar de onde ela foi extraída pode não ser a melhor opção para um país com tantas carências como é o Brasil.

Judiciário - Ano 2006. Conselho Nacional de Justiça. Disponível em $<$ http://www.cnj.jus.br/index.php?option=com_content $\&$ view $=$ category\&layout=blog \&id=206\&Itemid=245 $>$, acesso em 18/12/2008). 


\title{
CAPÍTULO 3 - AS CARACTERÍSTICAS DA TUTELA JURISDICIONAL DOS INTERESSES INDIVIDUAIS HOMOGÊNEOS
}

\begin{abstract}
3.1 - Aspectos introdutórios; 3.2 - Possibilidade da tutela coletiva de interesses individuais; 3.3 - Utilidade da tutela coletiva de interesses individuais; 3.4 - Conveniência da tutela coletiva de interesses individuais homogêneos; 3.4.1 - Considerações iniciais; 3.4.2 - Relevância do bem jurídico tutelado e da sua violação; 3.4.3 - Remoção de obstáculos ao acesso à justiça; 3.4.4 - Critérios para aferição da conveniência.
\end{abstract}

\section{1 - Aspectos introdutórios}

A caracterização da tutela coletiva de interesses individuais homogêneos consiste em esclarecer como se configuram os requisitos para que essa tutela seja cabível, isto é, possível, útil e adequada. Por outras palavras, é preciso vislumbrar a presença das condições da ação, ou seja, a possibilidade jurídica do pedido, a legitimação para a causa e o interesse de agir; nem poderia ser de outro modo, tratando-se igualmente de tutela jurisdicional, para a qual se exige a configuração do direito de ação em sentido concreto.

Por essa razão, a adequação do processo coletivo também deve ser aferida, de maneira que não será admissível a jurisdição coletiva na sua ausência, por falta de interesse de agir na via coletiva. Por outro lado, considerando quase sempre ser possível a opção pela jurisdição singular, a presença da adequação não impõe a tutela coletiva, apenas a torna mais conveniente para os interessados e também para o Estado-juiz. Mas conveniência não no sentido de que o seu cabimento fique subordinado a critérios discricionários e subjetivos, mas no sentido de que a efetividade da tutela jurisdicional será mais facilmente alcançada se for feita a opção por essa via processual, tendo em vista a presença de elementos suficientes para concluir pela superioridade do tratamento coletivo em relação ao tratamento individual desses interesses, aspecto que será tratado de maneira mais aprofundada ao longo deste capítulo. 
3.2 - Possibilidade da tutela coletiva de interesses individuais

É intuitivo que a homogeneidade constitui o requisito mais importante do qual decorre a possibilidade da tutela coletiva de interesses individuais. Não por outra razão, o próprio legislador assim denominou os interesses individuais sujeitos a essa espécie de tutela (art. 81, inciso III, da Lei n. 8.078/90). Interesses individuais heterogêneos, por consequência, não podem ser objeto de tutela coletiva.

Mas não é tão fácil definir e delinear essa homogeneidade. O Código de Defesa do Consumidor define interesses individuais homogêneos, de maneira bastante sucinta, como sendo aqueles "decorrentes de origem comum"76.

Ada Pellegrini Grinover, em seu conhecido estudo de Direito Comparado sobre a ação de classe brasileira ${ }^{77}$, sustenta que a heterogeneidade não é decorrência necessária da origem comum. Ensina ela que a origem comum, ou causa, pode ser próxima ou remota: próxima, ou imediata, como no caso da queda de um avião que vitima diversas pessoas; remota, ou mediata, como no caso de dano à saúde provocado por produto potencialmente nocivo, mas cuja causa próxima pode ter sido o uso inadequado ou as condições pessoais do usuário.

Para a autora, embora a redação do dispositivo legal induza a pensar que os interesses seriam homogêneos sempre que tivessem origem comum, isso não é verdade, necessariamente; eles serão tão menos homogêneos quanto mais remota for essa origem. Além disso, continua, se não prevalecerem os aspectos coletivos, os interesses devem ser considerados heterogêneos, ainda que tenham origem comum, sendo juridicamente impossível o pedido de tutela coletiva.

Já de início, é possível afirmar que a homogeneidade é uma característica que admite gradações, ou seja, os interesses individuais podem ser mais ou menos homogêneos. Não é rigorosamente correto qualificar os interesses individuais como homogêneos ou heterogêneos; o que se faz, na realidade, é definir se eles são homogêneos o bastante para serem considerados passíveis de tutela coletiva. Além disso, a homogeneidade necessária para a tutela coletiva constitui uma margem mínima; nada

\footnotetext{
${ }^{76}$ Art. 81, inciso III, do Código de Defesa do Consumidor (Lei n. 8.078, de 11/09/90).

77 Da class action for damages à ação de classe brasileira: os requisitos de admissibilidade. In: Revista Forense n. 352, Rio de Janeiro, out./nov./dez. 2000, p. 03/14.
} 
impede que interesses individuais diferentes tenham graus de homogeneidade diversos e, mesmo assim, sejam igualmente passíveis de tutela coletiva.

Por mais paradoxal que pareça, a homogeneidade não constitui um atributo dos interesses individuais do ponto de vista do Direito Processual, mas uma característica das próprias relações jurídicas de Direito Material que poderão ser submetidas ao processo, quando reciprocamente consideradas. Porém, como só apresenta relevância do ponto de vista do Direito Processual, assim como acontece com os interesses difusos e coletivos em sentido estrito, praticamente não há estudos a respeito de interesses transindividuais nas disciplinas voltadas aos direitos materiais, com exceção, mais recentemente, do Direito do Consumidor e do Direito Ambiental, ainda assim sempre em função da tutela judicial desses interesses. Por outro lado, a homogeneidade não pode ser considerada um atributo processual, uma vez que os direitos preexistem à sua tutela jurisdicional, de modo que a configuração da sua natureza independe da circunstância de estarem eles submetidos a um processo judicial ${ }^{78}$.

Assim, é no Direito Processual, no âmbito dos processos coletivos, que a questão da homogeneidade dos interesses individuais adquire importância. E isso justamente porque, se existirem interesses individuais homogêneos entre si, é possível o tratamento coletivo, na medida dessa homogeneidade. Questão diversa é saber se esse tratamento coletivo será útil ou será necessário, mas ele será juridicamente possível.

Em consequência, é essencial perscrutar em que consiste a homogeneidade. Teori Albino Zavascki ${ }^{79}$ aponta o núcleo de homogeneidade com base nos

\footnotetext{
${ }^{78}$ Nesse sentido, José Roberto dos Santos Bedaque (Direito e processo: influência do direito material sobre o processo. $4^{\mathrm{a}}$ ed. rev. amp. São Paulo: Malheiros, 2006, p. 39). Isso não significa que a natureza dos interesses metaindividuais não possa ser revelada, com maior clareza, a partir da análise do pedido trazido a juízo. O interesse é preexistente ao processo, mas muitas vezes só é possível distinguir de qual espécie de interesse coletivo se trata (difuso, coletivo ou individual homogêneo), considerando a correlação entre elas, pelo pedido e pela causa de pedir identificadores da ação. Nesses termos, correta a colocação de Kazuo Watanabe (In: GRINOVER, Ada Pellegrini et al. Código brasileiro de defesa do consumidor comentado pelos autores do anteprojeto. $5^{\mathrm{a}}$ ed. rev. atual. amp. Rio de Janeiro: Forense Universitária, 1998, p. 630), conforme também entende Pedro Lenza (Teoria geral da ação civil pública. São Paulo: Editora Revista dos Tribunais, 2003, p. 93), e sem razão a crítica formulada por Teori Albino Zavascki (Processo Coletivo Tutela de direitos coletivos e tutela coletiva de direitos. $2^{\mathrm{a}}$ ed. rev. atual. São Paulo: Editora Revista dos Tribunais, 2007, p. 41). Também Leandro Katscharowski Aguiar discorre sobre a importância da análise do pedido para identificação da natureza do direito deduzido (Tutela coletiva de direitos individuais e sua ехесис̧ão. São Paulo: Dialética, 2002, p. 28/30).
}

${ }^{79}$ Processo Coletivo - Tutela de direitos coletivos e tutela coletiva de direitos. $2^{\mathrm{a}}$ ed. rev. atual. São Paulo: Editora Revista dos Tribunais, 2007, p. 161. 
elementos da relação jurídica, ou seja, as relações jurídicas subjacentes aos interesses individuais homogêneos têm em comum a existência da obrigação (an debeatur), a identidade do devedor (quis debeatur) e a natureza da prestação (quid debeatur); para esse autor, a identidade do credor (cui debeatur) e a quantidade do que é devido (quantum debeatur) constituem a margem de heterogeneidade dos interesses individuais homogêneos.

A possibilidade de sentença genérica na ação coletiva para a defesa de interesses individuais homogêneos, "fixando a responsabilidade do réu pelos danos causados ${ }^{80}$, confirma esse entendimento, ao permitir a conclusão de que não fazem parte, necessariamente, do núcleo de homogeneidade dos interesses individuais tuteláveis coletivamente, a identidade do credor e a quantidade devida, uma vez que a sentença genérica tem a finalidade, justamente, de ensejar a formação de título apto a embasar ação de liquidação em favor dos interessados que manifestem desejo de comprovar a sua qualidade de credor e o valor dos danos que o devedor lhes causou, tratando-se de obrigação de indenizar.

É o caso, por exemplo, da ação de indenização de compradores de um modelo de automóvel com defeito de série $^{81}$. O pedido numa ação coletiva em defesa desses interesses individuais homogêneos poderá ser o de declaração da responsabilidade da ré, a fabricante do automóvel, a ressarcir os prejuízos causados a todos os compradores, fixando a existência da obrigação, sua natureza e o devedor, mas não os credores nem o valor das indenizações individuais a eles devidas. Da mesma forma, na ação de indenização de prejuízos pela remuneração de aplicação financeira inferior à contratada, o pedido poderá ser o de declaração da responsabilidade da instituição financeira a pagar os prejuízos causados, estabelecendo na sentença, igualmente, a existência da obrigação, sua natureza e o devedor. Também nesse caso a identificação dos credores e o valor devido a cada um deles ficariam para a fase de liquidação.

Mas a fórmula da sentença genérica, inserida no Código de Defesa do Consumidor, está naturalmente voltada para hipótese de danos infligidos aos consumidores, exigindo, via de regra, mais cedo ou mais tarde, sua identificação e a

\footnotetext{
${ }^{80}$ Art. 95 do Código de Defesa do Consumidor (Lei n. 8.078, de 11/09/90).

${ }^{81}$ O exemplo é de Hugo Nigro Mazzilli, A defesa dos interesses difusos em juízo. $15^{a}$ ed. rev. amp. atual. São Paulo: Saraiva, 2002, p. 49.
} 
quantificação dos prejuízos suportados por cada um deles, naquele caso. No entanto, considerando-se que as disposições do Título III do Código de Defesa do Consumidor (“Da Defesa do Consumidor em Juízo") são aplicáveis à defesa de quaisquer interesses individuais homogêneos ${ }^{82}$, o dispositivo deve ser interpretado no sentido de estar autorizada a sentença genérica, não de que ela seja obrigatória. Basta lembrar as sentenças declaratórias e constitutivas, que dispensam fase de execução, ou as sentenças condenatórias em obrigação de fazer, não fazer ou de entrega de coisa ${ }^{83}$, sempre que não haja necessidade de qualquer outra atividade para que o réu possa cumprir a sentença.

Além disso, existem também hipóteses de sentenças condenatórias em obrigação de pagar, ainda que raras, na prática, nas quais a sentença pode ser líquida, dispensando qualquer liquidação. Exemplo dessa hipótese, na qual os interessados e os danos suportados podem ser determinados pelo réu sem a necessidade de qualquer atividade posterior à sentença, seria a condenação ao pagamento de indenização pela falta de fornecimento do vale-refeição devido a servidores públicos de determinado município.

Por fim, há hipóteses em que a sentença será de tal natureza que ficará afastada a necessidade ou de identificação dos beneficiários ou de quantificação de danos sofridos. A condenação ao pagamento de vantagem pecuniária variável, estipulada em convenção coletiva de trabalho a trabalhadores de empresas de determinado ramo que

\footnotetext{
${ }^{82}$ Art. 117 do Código de Defesa do Consumidor (Lei n. 8.078, de 11/09/90).

${ }^{83}$ No mesmo sentido, Aloísio Gonçalves de Castro Mendes (Sentença, Liquidação e Execução nos Processos Coletivos para a tutela dos direitos individuais homogêneos. In: SANTOS, Ernane Fidélis dos; WAMBIER, Luiz Rodrigues; NERY JÚNIOR, Nelson; WAMBIER, Teresa Arruda Alvim (coord.). Execução Civil Estudos em homenagem ao professor Humberto Theodoro Júnior. São Paulo: Editora Revista dos Tribunais, 2007, p. 299/303). O autor exemplifica, em matéria de interesses individuais homogêneos, as sentenças declaratórias (declaração de inexigibilidade de tributos), (des)constitutivas (anulação de cláusula contratual consumerista de beneficiários predefinidos), condenatórias de obrigação de fazer (crédito em folha de pagamento de vantagem pecuniária de funcionários de empregadora ou de ente público) e de não fazer (vedação da cobrança de tarifas, nas contas-salários de funcionários públicos, por parte de instituição financeira).

Também Luiz Paulo da Silva Araújo Filho faz referência à utilização de ações coletivas em defesa de interesses individuais homogêneos que sejam meramente declaratórias ou constitutivas ou mesmo visando condenação em obrigação de fazer ou não fazer, com base nas disposições processuais do Código de Defesa do Consumidor (Tutela jurisdicional dos direitos individuais homogêneos. In: Revista Forense, São Paulo, mar./abr. 2002, p. 363/368). Da mesma forma, Rodolfo de Camargo Mancuso ensina que o conteúdo das sentenças em matéria de defesa coletiva de consumidores será o mais abrangente possível, incluindo as declaratórias, condenatórias, cominatórias (as que serão as mais usuais, para o autor) e também as inibitórias ou mandamentais (Manual do consumidor em juízo. $3^{\mathrm{a}}$ ed. rev. atual. amp. São Paulo: Saraiva, 2001, p. 124/129). Igualmente Ada Pellegrini Grinover leciona ser perfeitamente possível que a ação tendente à tutela de interesses individuais homogêneos objetive a condenação à obrigação de fazer ou não fazer, ou que seja de índole meramente declaratória ou constitutiva (Código brasileiro de defesa do consumidor comentado pelos autores do anteprojeto. $5^{\mathrm{a}}$ ed. rev. atual. amp. Rio de Janeiro: Forense Universitária, 1998, p. 673).
} 
deixaram de cumprir tal obrigação, e a condenação em obrigação de fazer consistente na substituição de componente defeituoso de determinado modelo de automóvel são exemplos de situações nas quais os réus já têm como identificar os credores ou já têm como determinar a prestação a ser cumprida em face de cada um deles ${ }^{84}$.

Nesses casos, o juiz deverá proferir a sentença mais líquida possível, não apenas para preservar a celeridade e a efetividade da tutela jurisdicional, como também porque, tendo sido a ele submetido pedido certo, isto é, em favor de pessoas e/ou em relação a prestações predeterminadas ou determináveis pelo réu, é vedado proferir sentença ilíquida ${ }^{85}$.

Para Kazuo Watanabe, a origem comum não precisa ser um único fato, nem precisa consistir em fatos ocorridos no mesmo momento ${ }^{86}$. Mas se não for um único fato, deverão ser fatos semelhantes, mesmo que ocorridos ao longo de muito tempo, ou seja, atos que violem o mesmo interesse, ainda que de pessoas diversas, resultando na mesma espécie de responsabilidade e incidindo sobre a mesma pessoa, responsável pela violação $^{87}$. Isso para que possam ser determinadas, também nesse caso, a existência da obrigação, a identidade do devedor e a natureza da prestação necessária para cumpri-la.

Um defeito de fabricação de certo automóvel fabricado pela empresa " $A$ " e um defeito de fabricação idêntico, porém de outro automóvel, fabricado pela empresa " $B$ ", não constituem "origem comum"; se uma mesma empresa automobilística fabrica um modelo " $X$ " com defeito e um modelo " $Y$ " com outro defeito, esses fatos não constituem origem comum; em ambas as hipóteses, a responsabilidade pelos danos causados aos

\footnotetext{
${ }^{84}$ José Marcelo Menezes Vigliar também cogita de situações nas quais o pedido e a sentença não serão genéricos, dispensando liquidação, dando igualmente como exemplo a tutela que veicule a obrigação de o fornecedor substituir uma peça defeituosa de determinado bem (Interesses individuais homogêneos e seus aspectos polêmicos. São Paulo: Saraiva, 2003, p. 99).

${ }^{85}$ Art. 459, parágrafo único, do CPC. No mesmo sentido, Teori Albino Zavascki, Processo Coletivo - Tutela de direitos coletivos e tutela coletiva de direitos. $2^{\mathrm{a}}$ ed. rev. atual. São Paulo: Editora Revista dos Tribunais, 2007, p. 163.

${ }^{86}$ In: GRINOVER, Ada Pellegrini et al. Código brasileiro de defesa do consumidor comentado pelos autores do anteprojeto. $5^{\mathrm{a}}$ ed. rev. atual. amp. Rio de Janeiro: Forense Universitária, 1998, p. 629.

87 Antonio Gidi refere que também no sistema norte-americano não se exige, para considerar atendido o requisito da existência de questões comuns, que "a conduta ilícita do réu seja exatamente a mesma em face de todos os membros do grupo. Diversas condutas semelhantes (ou mesmo diferentes) podem fazer parte de um plano traçado com o objetivo de lesar um grupo de pessoas. Em alguns casos, a diversidade das condutas isoladas pode ser desconsiderada, emergindo um núcleo comum na conduta da parte ré (common core of conduct)" (A class action como instrumento de tutela coletiva dos direitos. São Paulo: Editora Revista dos Tribunais, 2007, p. 85).
} 
compradores não decorre das mesmas circunstâncias. Nesses casos, os interesses não seriam homogêneos, mas heterogêneos, e um pedido indenizatório em ação coletiva que tratasse indistintamente todos esses fatos seria juridicamente impossível.

Portanto, a origem comum dos interesses individuais, entendida nos seus devidos termos, como visto, implica a existência de uma obrigação, a identidade de um devedor e uma prestação devida, comuns a todos os credores. Por essa razão, conclui-se que de uma origem comum resultam, necessariamente, interesses individuais homogêneos como previstos na lei, vazada precisamente dessa forma ${ }^{88}$. A questão da predominância dos elementos coletivos não é irrelevante, mas dela não decorre a homogeneidade e sim a utilidade da tutela coletiva. Por outras palavras, os interesses individuais decorrentes de origem comum são sempre homogêneos, mas nem sempre haverá utilidade na sua tutela judicial coletiva ${ }^{89}$.

No exemplo antes mencionado, do dano à saúde provocado por produto potencialmente nocivo, mas cuja causa próxima pode ter sido o uso inadequado ou as condições pessoais do usuário, a exata compreensão do problema reside mais na identificação da origem comum, da qual decorre o interesse, do que na distinção entre origem próxima e remota. Se o dano de determinado indivíduo foi causado pelo uso inadequado, o seu interesse não decorre da nocividade do produto. Se a nocividade do produto não foi a causa do dano, ou seja, se a nocividade potencial não resultou em nocividade real ou efetiva do produto em relação a esse indivíduo, o seu interesse não é homogêneo em comparação com os interesses daqueles beneficiados pela sentença genérica, cujos danos foram causados pelo produto, não pelo uso inadequado. Do ponto de vista processual, havendo uma sentença genérica em desfavor da empresa fabricante do produto, a defesa desta em sede de liquidação individual ajuizada por esse indivíduo será a alegação de que ele não é credor, uma vez que a origem do seu interesse não é comum em

\footnotetext{
${ }^{88}$ Nesse sentido, Antonio Gidi, para quem “... a homogeneidade decorre tão-só e exclusivamente da origem comum dos direitos...” (Coisa julgada e litispendência em ações coletivas. São Paulo: Saraiva, 1995, p. 32).

${ }^{89}$ Em sentido contrário, Ricardo Castilho (Acesso à justiça. São Paulo: Atlas, 2006, p. 57), sustenta ser a homogeneidade mais do que decorrência da origem comum, exigindo-se também a prevalência dos aspectos coletivos sobre os individuais.
} 
comparação com os beneficiários da sentença. O mesmo raciocínio se aplica à hipótese de dano provocado pelas condições pessoais do usuário de produto potencialmente nocivo ${ }^{90}$.

Produtos tipicamente considerados potencialmente nocivos são, entre muitos outros, as bebidas alcoólicas. O consumidor que pretender obter indenização pelo consumo desse produto deverá comprovar que sofreu dano (p. ex., o desenvolvimento de uma moléstia hepática) em decorrência da nocividade de um produto desse tipo, ou seja, que a potencialidade nociva, no seu caso, tornou-se efetiva. Se o dano, ao contrário, foi provocado pelo uso inadequado do produto (p. ex., pelo uso imoderado), a nocividade a ele inerente não foi a causa, já que ela não chegou a se tornar concreta. Havendo uma sentença em ação coletiva condenando uma empresa produtora de determinada bebida alcoólica a indenizar consumidores prejudicados pelo seu uso, os interessados deverão comprovar que o dano por eles sofrido foi provocado pelo simples uso do produto, sua nocividade efetiva, não pelo seu uso incorreto, que poderia ser até alegado pelo produtor como excludente de responsabilidade ${ }^{91}$.

Nesse ponto, duas questões de conteúdo material precisam ser esclarecidas. A primeira é que a origem comum cogitada nada tem a ver com a obrigação dos fornecedores de produtos potencialmente perigosos ou nocivos de informar de maneira ostensiva e adequada sobre essas características ${ }^{92}$. Tal obrigação é distinta daquela decorrente de eventual acidente de consumo. Por exemplo, o fabricante de fogos de artifício, produto potencialmente perigoso, pode ser responsabilizado, administrativa e penalmente, pelo inadimplemento da obrigação de informar o consumidor a esse respeito ${ }^{93}$, mas também pode, independentemente disso, ser responsabilizado por acidente provocado pelos seus produtos, como no caso de explosão prematura ou espontânea. A falta da informação pode alterar a configuração do que deveria ser considerado uso inadequado, uma vez que o consumidor poderia não conhecer o grau de periculosidade do produto e, por essa razão, ser levado a usar incorretamente o produto, mas não é ela que vai

\footnotetext{
${ }^{90}$ Questão diversa é a da existência de uma causalidade geral e outra específica, ou seja, quando é preciso primeiro provar que o produto é potencialmente perigoso ou nocivo, depois que esse perigo ou nocividade tornou-se concreto em relação a determinada pessoa (por exemplo, danos à saúde causados pelo uso do tabaco). $\mathrm{O}$ assunto, igualmente mais ligado à questão da utilidade da tutela coletiva, será abordado no tópico seguinte.

${ }^{91}$ Art. 12, parágrafo $3^{\circ}$, inciso III, “culpa exclusiva do consumidor ou de terceiro".

${ }^{92}$ Art. $9^{\circ}$ do Código de Defesa do Consumidor.

${ }^{93}$ Arts. 55 e 63 do Código de Defesa do Consumidor.
} 
caracterizar o nexo de causalidade aqui discutido, uma vez que não é essa falta de informação a origem comum dos interesses violados, ou seja, o dano provocado por um defeito do produto.

A segunda questão é que a possibilidade de haver multiplicidade de causas para o evento danoso, ou seja, de terem existido duas ou mais circunstâncias concorrendo para que o dano fosse provocado, não invalida o raciocínio. No exemplo da bebida alcoólica, se o dano foi provocado exclusivamente pelo produto defeituoso, não há concausa e existe nexo causal entre ambos; se o dano foi causado unicamente pelo uso inadequado, também não há concausa e não existe nexo causal entre o produto defeituoso e o dano; mas se o dano foi causado pelo produto defeituoso e também pelo uso indevido, aí a questão da responsabilidade passará pela análise dessas concausas, com base na legislação e nas teorias que procuram resolver o problema do nexo de causalidade para fins de responsabilidade civil ${ }^{94}$. Seja como for, toda vez que o defeito do produto não for pelo menos uma das causas do dano, o interessado não poderá valer-se de sentença que tenha reconhecido a responsabilidade do fornecedor com base na origem comum dos interesses violados por defeito do produto.

\section{3 - Utilidade da tutela coletiva de interesses individuais}

A sentença genérica, que não identifica os credores nem quantifica as prestações a que eles fazem jus, foi uma criação do Código de Defesa do Consumidor. Porém, mesmo na jurisdição singular e antes do estatuto consumerista, com base nas leis processuais, era e continua sendo possível ao juiz relegar a determinação do valor devido para depois da sentença, na fase de liquidação ${ }^{95}$. Explica Teori Albino Zavascki que “do

\footnotetext{
${ }^{94}$ Em voto proferido na relatoria do Recurso Extraordinário n. 130.764-PR (DJ de 07/08/92, p. 11782), o exMinistro Moreira Alves, do Supremo Tribunal Federal, mencionou as teorias da interrupção do nexo causal, da equivalência das condições e da causalidade adequada, sustentando que, por força do art. 1.060 do Código Civil de 1916, a legislação adotou a primeira, segundo a qual, concausa superveniente só rompe o nexo causal original se dela o dano for efeito necessário. No âmbito consumerista, em princípio, a conclusão seria também defensável, uma vez inexistir norma específica no Código de Defesa do Consumidor e tendo em vista que o art. 403 do atual Código Civil manteve praticamente inalterada a norma ("ainda que a inexecução resulte de dolo do devedor, as perdas e danos só incluem os prejuízos efetivos e os lucros cessantes por efeito dela direto e imediato, sem prejuízo do disposto na lei processual"). De qualquer modo, a questão refoge aos objetivos deste trabalho.

95 "Quando a sentença não determinar o valor devido, procede-se à sua liquidação" (art. 475-A do CPC; art. 603, na redação anterior à Lei n. 11.2332/2005).
} 
ponto de vista científico, nada impede - pelo contrário, é até recomendável - que toda a atividade cognitiva, inclusive no que se refere aos contornos mais elementares da prestação devida, se exaura numa única fase da relação processual. No entanto, os reclamos de ordem prática tracionam em outra direção. Casos há, com efeito, em que a apuração do quantum debeatur impõe dispêndio de enormes quantidades de tempo, energia e recursos com a produção de provas, que serão de absoluta inutilidade se a sentença concluir que a demanda é improcedente" ${ }^{\text {"96. }}$

Existe também a previsão legal de liquidação, na esfera cível, da sentença penal condenatória ${ }^{97}$, que igualmente reserva para um processo de liquidação a definição completa da obrigação reparatória, onde será definido o valor devido à vítima da ação penal, exequente na esfera civil ${ }^{98}$. Em ambos os casos a obrigação está definida no tocante à existência da obrigação, à identidade do devedor, à natureza da prestação, da mesma forma que a sentença genérica da ação que tutela interesses individuais homogêneos, além de também definir a identidade do credor. Para a ação de liquidação, resta apenas o objetivo de fixar a quantidade do que é devido.

Portanto, não é novo o problema de saber se é útil para o autor uma sentença nessas condições, isto é, ilíquida ${ }^{99}$.

A utilidade da sentença, naturalmente, depende do esforço que o autor ainda terá de despender para obter o bem da vida objeto do processo. Se a totalidade ou, pelo menos, parte importante do esforço total a ser despendido pela parte para a obtenção da tutela pretendida for exigido antes da sentença, ela terá sido útil; se todo ou quase todo o

\footnotetext{
${ }^{96}$ Processo Coletivo - Tutela de direitos coletivos e tutela coletiva de direitos. $2^{\mathrm{a}}$ ed. rev. atual. São Paulo: Editora Revista dos Tribunais, 2007, p. 164.

${ }^{97}$ Arts. 63 a 68 do CPP, art. 91, inciso I, do CP e art. 584, inciso II, do CPC.

${ }^{98}$ A rigor, na execução civil de sentença penal condenatória, é possível alterar o que ficou definido na esfera criminal: tanto o autor pode demonstrar a legitimidade passiva de um responsável civil pelo dano, no lugar do autor do crime (art. 64 do CPP), como também o réu pode demonstrar a existência de causa excludente de responsabilidade civil, desde que inadmissível na seara penal. Para uma comparação entre a sentença condenatória genérica do art. 95 do Código de Defesa do Consumidor e a sentença penal condenatória, v. Luiz Paulo da Silva Araújo (Ações coletivas: a tutela jurisdicional dos direitos individuais homogêneos. Rio de Janeiro: Forense, 2000, p. 134/137).

${ }^{99}$ Para Rodrigo Souza Mendes de Araújo, um meio-termo entre a lei e a sentença líquida (A ação para a tutela dos interesses individuais homogêneos: a class action for damages brasileira? In: MAZZEI, Rodrigo; NOLASCO, Rita (org.). Processo civil coletivo. São Paulo: Quartier Latin, 2005, p. 704). Para Antonio Gidi, um meio termo entre "uma norma individual e concreta como as sentenças comumente são" e "uma norma geral e abstrata como as leis" (Coisa julgada e litispendência em ações coletivas. São Paulo: Saraiva, 1995, p. 139).
} 
esforço terá de ser despendido depois, na fase de liquidação e execução, então a sentença terá sido inútil.

O processo coletivo nada mais faz do que concentrar em um único feito, sob a responsabilidade do autor coletivo, as energias que os vários titulares dos interesses individuais homogêneos despenderiam em seus hipotéticos processos individuais. É inegável a vantagem de evitar a proliferação de demandas múltiplas e repetidas, ou seja, nas quais as mesmas questões são discutidas e, tratando-se de questões fáticas, as mesmas provas precisarão ser produzidas $^{100}$.

Porém, como visto, os interesses individuais podem possuir uma margem de homogeneidade que permite o seu tratamento coletivo, que consiste na possibilidade de definir, num único processo, a obrigação do réu em face de todos os titulares desses interesses no que ela tiver de homogênea. Isso significa dividir o esforço de obtenção do bem da vida almejado em duas fases: a primeira delas coletiva, na qual o autor coletivo, de uma só vez e em benefício de todos os interessados, deverá provar a existência da obrigação, a identidade do devedor e a natureza da prestação; a segunda fase individual, na qual apenas será definido quem é credor e a quantidade da prestação.

A vantagem consiste precisamente na dispensa de cada um dos interessados produzir novamente essa mesma prova. Naturalmente, cada um deles vai precisar, na segunda fase, de liquidação individual da sentença genérica, provar a sua qualidade de credor e a prestação que lhe é devida, mas isso também teria de ser feito se cada um tivesse movido ações individuais desde o início.

Assim, se o autor coletivo tiver pelo menos a possibilidade de definir completamente a margem mínima de homogeneidade (obrigação, devedor e prestação), seja mediante demonstração das suas alegações de direito, seja por meio da comprovação de suas alegações de fato, o processo coletivo na defesa de interesses individuais homogêneos apresentará utilidade; caso contrário, não. Ocorre que a possibilidade de obter essa definição depende da natureza da defesa cabível a ser utilizada pelo réu. Se essa defesa consistir na alegação (devidamente comprovada, conforme o caso) de situações individuais, a discussão sairá do plano coletivo e não poderá ser tratada senão na fase de

\footnotetext{
${ }^{100}$ V. nota 56.
} 
liquidação. É nesse caso que o processo coletivo perde a utilidade, porque fica inviabilizada a sentença genérica que defina pelo menos o núcleo de homogeneidade exigido na tutela coletiva de interesses individuais homogêneos, como visto no tópico anterior.

Não é que os interesses individuais sob exame não sejam homogêneos, mas a prova completa dessa homogeneidade passa pela comprovação de que inexistem causas individualizadas para o dano ocorrido. Ou seja, o autor coletivo alega uma origem comum, enquanto o réu se defende alegando causas individuais. Ainda que a alegação do réu seja inverídica, a obrigatoriedade de discutir questões individuais, de direito ou, pior ainda, de fato, já inviabiliza o tratamento coletivo.

Por exemplo, se a tutela pretendida referir-se à condenação de determinada indústria farmacêutica de indenizar danos provocados por um medicamento de sua fabricação e ficar claro que a demonstração da causalidade depende da comprovação da inexistência de determinadas condições pessoais (como uma suscetibilidade maior), será impossível definir, no processo coletivo, a obrigação, o devedor e o tipo de prestação por ele devida. Por outro lado, uma pretensão de obter o reajuste de benefícios previdenciários com base em determinado ato normativo descumprido pelo órgão pagador não passa pela discussão de qualquer questão individual, pois não há alegações de defesa cabíveis capazes de deslocar a controvérsia do plano coletivo para o individual. Nesse caso, há a possibilidade efetiva de definir a obrigação nos termos da sentença genérica, ou seja, defini-la no tocante à existência do dever de aplicar a norma descumprida, à identidade do devedor e ao tipo de prestação, isto é, determinar o pagamento das diferenças das parcelas vencidas e a implantação do reajuste das parcelas vincendas.

É nesse sentido que a prevalência, preponderância ou predominância das questões individuais inviabiliza a tutela coletiva de interesses individuais homogêneos. A discussão visando definir a margem mínima de homogeneidade passa, necessariamente, por questões de cunho individual. Pode até ser que, em determinados casos, o réu consiga provar que a origem de certo interesse tenha sido exclusivamente individual, quando restará provado não se tratar de interesse homogêneo em relação aos demais, como já visto. Mas o problema é o mesmo, ainda que se trate, verdadeiramente, de interesses homogêneos, efetivamente beneficiáveis pela hipotética sentença genérica: se a 
controvérsia tiver de envolver a discussão de questões individuais, o tratamento coletivo fica, desde o início, comprometido.

Portanto, a prevalência de questões coletivas sobre as individuais não significa que aquelas sejam mais importantes ou mais numerosas ou, ainda, que demandem comprovação mais difícil ou custosa. Significa que existem e não podem ser afastadas, pelo menos não de plano, alegações do réu visando questionar a homogeneidade dos interesses com base na presença de causas individuais. Por outras palavras, a alegação de defesa é a de que, naquele caso, os interesses não são homogêneos, mas heterogêneos, pois cada possível interessado experimentou prejuízos em decorrência de causas diversas, de natureza individual.

Esse não é o caso das violações em que a causalidade precisa ser comprovada no plano geral e no específico, como ocorre com os danos à saúde provocados pelo contato com determinados produtos, como o asbesto, por exemplo. A necessidade de comprovar primeiro que esse contato é danoso à saúde para somente depois comprovar que determinada pessoa sofreu esses danos não compromete, em princípio, o tratamento coletivo da matéria. É que, para tornar possível a sentença genérica, como visto, basta definir a existência da obrigação, a identidade do devedor e a natureza da prestação. Se o réu é responsável pelo contato de pessoas com produto efetivamente nocivo (não apenas potencialmente), então ele será responsável, em princípio, pela obrigação de reparar os danos de todas as pessoas que tenham ficado doentes em virtude desse contato.

O réu não terá, nesse caso, defesa de caráter individual, uma vez que a alegação do autor coletivo (a ser demonstrada mediante prova reconhecidamente difícil e onerosa) é que o produto é nocivo ou perigoso, não que o contato do produto tenha provocado o dano. A prova de que o contato foi danoso especificamente em relação a cada interesse pode e deve ficar para a fase de liquidação da sentença genérica. É nesse momento que cada interessado deverá comprovar sua qualidade de devedor, bem como a extensão dos danos sofridos.

Sendo assim, não se pode dizer que numa ação coletiva desse tipo haja predominância de elementos individuais, pois, ao contrário, tais elementos só aparecerão 
na fase de liquidação. Em consequência, não se pode dizer também que inexista utilidade numa sentença genérica desse tipo ${ }^{101}$.

De fato, no exemplo mencionado, a prova da nocividade do contato com o asbesto é suficiente para o tratamento coletivo do pedido, dotado de aptidão para produzir uma sentença genérica que declare a responsabilidade do fabricante, a sua obrigação perante os lesados (de reparar os danos causados) e a natureza dessa prestação (indenizatória) ${ }^{102}$. Em resumo, o critério para aferição da utilidade deve resumir-se à verificação da possibilidade de prolação da sentença genérica sem a incidência de questões de defesa de caráter individual.

Ainda que se adote um critério mais rigoroso para aferição da utilidade da sentença genérica, ele não pode ser empregado para inviabilizar a tutela judicial. Se, no caso concreto, a prova individual se revelar tão difícil e onerosa que já se possa inferir sua inviabilidade em sede individual, a via do processo coletivo não deve ser obstada. É exatamente o caso de prova extremamente difícil e cara para ser feita num processo

\footnotetext{
${ }^{101}$ Nesse mesmo sentido, Rodrigo Souza Mendes de Araújo (A ação para a tutela dos interesses individuais homogêneos: a class action for damages brasileira? In: MAZZEI, Rodrigo; NOLASCO, Rita (org.). Processo civil coletivo. São Paulo: Quartier Latin, 2005, p. 709). Não obstante, o autor sustenta essa possibilidade sob o fundamento de que o requisito da superioridade da tutela coletiva não foi positivado na tutela coletiva, sequer sendo possível comparar a tutela coletiva com a individual para averiguar qual delas é superior, por terem objetivos distintos. Parece, entretanto, possível fazer a comparação se considerado o percurso completo de cada uma das duas vias processuais, ou seja, entre a tutela coletiva (sentença genérica, seguida de liquidação e execução individuais) e a tutela individual (ação individual condenatória). E o requisito da superioridade, conforme o próprio autor reconhece, pode ser considerado um sinônimo do requisito da utilidade.
}

A questão reside mais no juízo sobre a utilidade desse tipo de sentença genérica do que em saber se o requisito da superioridade das "class action for damages" também deve ser observado no processo coletivo brasileiro. Se a superioridade do processo coletivo em relação ao individual é a outra face da utilidade daquele, não há dúvida de que a superioridade é um dos seus requisitos.

Mais difícil é definir se é útil uma sentença que condene uma indústria tabagista a indenizar os danos causados pura e simplesmente pelo consumo dos cigarros que vendeu, cabendo a cada interessado provar, na liquidação individual, que fumou daqueles cigarros, ficou doente e a sua doença foi causada por esse hábito, defendendo-se das muitas alegações de caráter individual que certamente a ré vai apresentar. Para Ada Pellegrini Grinover, não há utilidade numa sentença como essa, também com base na jurisprudência americana, caso Dianne Castano et al. v. The American Tobacco Company et al. (Da class action for damages à ação de classe brasileira: os requisitos de admissibilidade. In: Revista Forense n. 352, Rio de Janeiro, out./nov./dez. 2000, p. 12).

102 José Rogério Cruz e Tucci menciona caso de grande repercussão nos Estados Unidos da América em que foi admitida ação coletiva para determinar apenas a existência e a natureza dos danos resultantes do contato de soldados com uma substância tóxica denominada "agente laranja", durante a Guerra do Vietnã, rejeitando-se o pedido para que a quantificação dos danos individuais fosse promovida no mesmo processo, cabendo aos interessados propor ações individuais posteriormente ("Class action" e mandado de segurança coletivo. São Paulo: Saraiva, 1990, p. 30). 
individual, como no exemplo acima citado. Não considerar útil uma sentença genérica em casos assim tem o efeito de negar a única tutela judicial viável.

Nessa mesma ordem de ideias, o processo coletivo apresenta, em relação ao processo individual, um conjunto de vantagens tão importante que a avaliação da utilidade da sentença genérica precisa ser feita de forma excludente, ou seja, de maneira a identificar apenas as situações em que, claramente, inexista vantagem. Havendo vantagem, por menor que seja, o requisito da utilidade deve ser considerado atendido.

Não se pode esquecer que deixar de reconhecer a utilidade sob o pretexto de ser diminuta a vantagem, porque a questão coletiva a ser decidida é pouco relevante em comparação com as muitas questões individuais passíveis de alegação, corresponde a restringir a solução do problema apenas a duas possibilidades: a repetição incansável da definição, antecedida da necessária comprovação, da questão coletiva, nos inúmeros processos individuais resultantes, ou a inviabilização da tutela, diante dos obstáculos ao acesso à justiça não superados pelo processo individual ${ }^{103}$.

A inviabilização da tutela constitui alternativa por demais repelida, cuja inconveniência dispensa maiores comentários. Mas a repetição indefinida, em processos individuais, da solução da questão coletiva, por menos importante que pareça em comparação com as diversas questões individuais, também é alternativa inaceitável.

Pensemos no exemplo do asbesto. Inúmeros interessados teriam de mover processos individuais nos quais precisariam comprovar que o contato com o produto lhes causou danos à saúde, a extensão desses danos e a responsabilidade do fabricante (o seu comportamento e o nexo de causalidade entre esse comportamento e o dano causado), mas antes disso precisariam produzir prova de que o asbesto faz mal à saúde. Seriam dezenas de processos em que, no início da fase probatória, cada autor deveria produzir a mesmíssima prova de nocividade do asbesto, complexa e cara. Ora, ainda que tal prova represente pequena parcela de todas as questões envolvidas a serem decididas, evidente a inutilidade dessa repetição e a conveniência de que seja possível, com o respeito a todas as garantias processuais, que essa questão seja resolvida de uma vez por todas, num processo coletivo.

${ }^{103} \mathrm{O}$ tema será detalhado no tópico seguinte. 
Outro argumento é que a importância relativa da questão coletiva não será igual em todos os casos. Haverá, certamente, interessados em relação aos quais nem sequer será cabível opor muitas questões de defesa, ou em face dos quais a discussão dessas questões não chegará a ser tão complexa. Assim, para esses interessados, a utilidade da sentença genérica será ainda maior.

Exemplo dessa situação seria o de um trabalhador já aposentado por invalidez decorrente de doença incapacitante, a mesma que se pretende ver declarada na sentença genérica como sendo provocada pelo produto fabricado pela empresa-ré. Para esse interessado, em ação de liquidação individual da sentença genérica, além da extensão dos danos sofridos, bastará provar que a doença foi efetivamente provocada pelo contato com o produto, nada mais (é claro que o réu poderá questionar a concessão dessa aposentadoria, na ausência de coisa julgada a esse respeito que lhe atinja, mas o ônus de provar o descabimento lhe pertence).

Por último, não havendo elementos suficientes para se chegar a uma conclusão sobre a sua inutilidade, a via coletiva deve ser permitida, tendo em vista o princípio da inafastabilidade da jurisdição ${ }^{104}$. E se a questão da utilidade só for aferível concretamente em momento posterior, deve também o juiz considerar a condição atendida, pelo menos na fase postulatória, tendo em vista a utilidade potencial da via coletiva e a possibilidade de extinção do processo a qualquer momento, quando se mostrar efetivamente inútil ${ }^{105}$.

\section{4 - Conveniência da tutela coletiva de interesses individuais homogêneos}

\subsection{1 - Considerações iniciais}

Os interesses individuais originados nas relações jurídicas de massa podem exibir grande importância social. Na verdade, o simples fato de ter havido uma violação de massa já confere relevância a essa situação; mas, em reforço, os interesses

\footnotetext{
${ }^{104} \mathrm{~V}$. Nelson Nery Júnior, sustentando ainda que a tutela jurisdicional garantida constitucionalmente é aquela "adequada" para o jurisdicionado (Princípios do processo civil na constituição federal. $8^{a}$ ed. São Paulo: Editora Revista dos Tribunais, 2004, p. 130). No caso, a tutela adequada, a toda evidência, é a coletiva, não a individual.

${ }^{105}$ Art. 267, inciso VI e parágrafo $3^{\circ}$, do CPC.
} 
podem também ser daqueles especialmente protegidos pelo ordenamento jurídico. Ao mesmo tempo, em virtude das próprias características desses interesses, podem levantar-se grandes obstáculos para a sua defesa jurisdicional, maiores até do que as barreiras que se apresentam perante os interesses individuais heterogêneos, tutelados na jurisdição singular.

Esse binômio, relevância social da violação originária de interesses individuais homogêneos e dificuldade dos obstáculos ao acesso à justiça, constitui a equação para determinação da conveniência da tutela coletiva, revelada pela sua superioridade sobre a tutela individual ${ }^{106}$. Quanto maior a importância do bem violado, ou mesmo da própria violação, maior a importância de que a pretensão a uma reparação possa ser levada a juízo pelos seus titulares. Ao mesmo tempo, quanto mais difíceis de transpor forem esses obstáculos, mais indispensáveis os meios aptos a sobrepujá-los, ainda que se trate de interesses menos relevantes ${ }^{107}$.

Interesse social pode ser conceituado como sendo "situações, fatos, atos, bens e valores que, de alguma forma, concorrem para preservar a organização e o funcionamento da comunidade jurídica e politicamente considerada, ou para atender suas necessidades de bem-estar e desenvolvimento"108, ou ainda "o interesse concernente à maioria da sociedade civil, que reflete o que esta sociedade entende por bem comum"109.

Trata-se, portanto, de viabilizar a tutela jurisdicional para os indivíduos lesados nas relações jurídicas de massa como forma de promover a defesa de interesses socialmente relevantes, mas também é preciso assegurar que a ordem jurídica tornada

\footnotetext{
${ }^{106}$ Para Rodolfo de Camargo Mancuso, "é lícito supor que sempre há de preexistir a relevância do interesse para a sociedade civil, embora esse quesito possa apresentar diversa gradação e mesmo, no caso dos individuais homogêneos, derivar da conveniência do trato processual coletivo, mormente agora com as restrições à formação do litisconsórcio ativo facultativo "multitudinário"” (Ação civil pública. $5^{\mathrm{a}}$ ed. rev. atual. amp. São Paulo: Editora Revista dos Tribunais, 1997, p. 36).

${ }^{107}$ A utilidade da jurisdição coletiva para promover o acesso à justiça é amplamente reconhecida. A doutrina chega a divisar três fases ou "ondas" do movimento pelo acesso à justiça: a primeira "onda" correspondeu aos esforços para proporcionar assistência judiciária aos necessitados; a segunda, relacionou-se com a representação jurídica para os interesses coletivos ou grupais; e a terceira, consistiu em uma concepção mais ampla de acesso à justiça, não restrita à representação em juízo, mas também voltada ao aperfeiçoamento das instituições, mecanismos, pessoas e procedimentos dispostos a processar ou prevenir litígios (Mauro Cappelletti e Bryant Garth, Acesso à justiça. Porto Alegre: Sergio Antonio Fabris Editor, 1988, p. 67-68).

${ }^{108}$ V. Teori Albino Zavascki, Processo Coletivo - Tutela de direitos coletivos e tutela coletiva de direitos. $2^{\mathrm{a}}$ ed. rev. atual. São Paulo: Editora Revista dos Tribunais, 2007, p. 232.

${ }^{109}$ V. Letícia Rezende Castelo Branco, Legitimidade ativa do Ministério Público nas ações coletivas para a defesa dos interesses individuais homogêneos. In: Repertório de Jurisprudência IOB, vol. III, n. 10, São Paulo, $2^{\text {a }}$ quinzena de maio 2007, p. 293.
} 
acessível seja qualificada, isto é, efetiva para prevenir, reprimir e reparar essas lesões ${ }^{110}$. Para esse fim, indispensável afastar os obstáculos que se colocam e o processo coletivo, seguramente, constitui solução bastante apropriada para remover alguns deles ${ }^{111}$.

Assim, a conveniência da tutela coletiva de interesses individuais homogêneos é determinada pela sua capacidade tanto de defender valores sociais relevantes como de remover obstáculos ao acesso à justiça, características a seguir examinadas.

\subsection{2 - Relevância do bem jurídico tutelado e da sua violação}

Muitos interesses individuais homogêneos se caracterizam por serem posições jurídicas resultantes da lesão de direitos assegurados pela própria Constituição Federal. Com efeito, dentre os direitos cuja violação resultam interesses individuais homogêneos consistentes em obrigações de indenizar, geralmente incidem as garantias constitucionais do consumidor (art. $5^{\circ}$, inciso XXXII, e art. 170, inciso V), dos direitos sociais da educação e da saúde (art. $6^{\circ}$ ), da proteção ao meio ambiente (art. 23, inciso VI), entre outros. Da mesma forma, outras espécies de obrigação (de fazer, não fazer etc.) podem constituir interesses individuais homogêneos gerados pela violação a diversos direitos igualmente assegurados na Constituição Federal, como a previdência social, o trabalho, bem como a preservação do poder aquisitivo de salários e proventos $\left(\operatorname{arts} .6^{\circ}, 7^{\circ}\right.$, inciso IV, 194, parágrafo único, inciso IV), entre muitos outros.

Ora, se o constituinte previu tais garantias, elegendo tais direitos como merecedores de proteção especial, de estatura constitucional, os interesses resultantes de lesões a eles provocadas precisam merecer mecanismos de salvaguarda eficazes, a serem

\footnotetext{
${ }^{110}$ Para Kazuo Watanabe, uma "ordem jurídica justa" (Acesso à justiça e sociedade moderna. In: GRINOVER, Ada Pellegrini; DINAMARCO, Cândido Rangel; WATANABE, Kazuo. Participação $e$ processo. São Paulo: Editora Revista dos Tribunais, 1988, p. 128-135). Para Rodolfo de Camargo Mancuso, uma resposta judiciária de boa qualidade "a saber, jurídica, motivada, equânime, prestada em tempo razoável, ou, numa palavra, o adimplemento estatal ao direito de todo brasileiro a uma ordem jurídica justa" (Ação civil pública trabalhista: análise de alguns pontos controvertidos. In: Revista dos Tribunais n. 732, São Paulo, Editora Revista dos Tribunais, out. 1996, p. 11-37). Para Candido Rangel Dinamarco, "um processo justo, ou processo équo, que é composto pela efetividade de um mínimo de garantias de meios e de resultados" (Instituições de direito processual civil - vol. I. $4^{\mathrm{a}}$ ed. rev. atual. São Paulo: Malheiros, 2004, p. 115).

${ }^{111}$ V. Mauro Cappelletti e Bryant Garth, Acesso à justiça. Porto Alegre: Sergio Antonio Fabris Editor, 1988, p. $15-29$.
} 
assegurados pela legislação, até mesmo para atendimento ao princípio hermenêutico da máxima efetividade das normas constitucionais. Se a tutela coletiva de interesses individuais homogêneos nessas condições é possível e útil, então ela não pode ser obstada.

A relevância de alguns desses direitos está estampada também pela circunstância de serem considerados legalmente indisponíveis, mediante diversas normas processuais, como a invalidade da confissão, em juízo, de fatos relativos a esses direitos, a inaplicabilidade, em relação a eles, dos efeitos da revelia ou a proibição de ônus probatório assumido sem previsão legal (arts. 351, 320, inciso II, e 333, parágrafo único, inciso I) ${ }^{112}$. A indisponibilidade apresenta grande importância no tema da tutela coletiva dos interesses individuais homogêneos, uma vez que é considerada indispensável para configurar a legitimação do Ministério Público. É o caso dos direitos das crianças e adolescentes (art. 227 da Constituição Federal), entre eles o direito à profissionalização e à cultura. O tema será tratado no capítulo 5 deste trabalho.

Mas a própria violação de direitos geradora dos interesses individuais homogêneos também indica o grau de relevância da tutela respectiva. Quanto mais grave é a violação, maior a repercussão social que ela provoca e maior a necessidade da tutela jurisdicional adequada.

Por esse aspecto, a amplitude da lesão é importante indicador da relevância da tutela jurisdicional visando sua reparação. A lesão ocorrida em relações jurídicas de massa muitas vezes alcança grande amplitude local ou regional, às vezes até mesmo nacional. Por si só, essa amplitude quase sempre implica uma grande repercussão social da insatisfação então gerada, o que exige a resposta do Estado, no mínimo de caráter reparatório, a reclamar, como regra, a atuação da jurisdição ${ }^{113}$, sob pena de disseminar na sociedade uma forte sensação de ausência de autoridade. São exemplos de violações de grande amplitude as que resultam de inobservância de direitos previdenciários, como os reajustes de benefícios previstos em lei, ou as provocadas por acidentes de consumo de

\footnotetext{
${ }^{112}$ Exemplos citados por Teori Albino Zavascki (Ministério Público, ação civil pública e defesa de direitos individuais homogêneos. In: Revista Forense, vol. 92, n. 333, Rio de Janeiro, jan./fev./mar. 1996, p. 123/137).

${ }^{113}$ Para uma exposição do papel do processo em geral na pacificação das insatisfações sociais, v. Cândido Rangel Dinamarco (Instrumentalidade do processo. 13 ${ }^{\mathrm{a}}$ ed. rev. atual. São Paulo: Malheiros, 2008, p. 189), para quem o escopo social das atividades jurídicas do Estado é "eliminar conflitos mediante critérios justos".
} 
produtos de larga distribuição, como os causados por defeitos de fabricação de aparelhos eletrodomésticos populares.

A propósito da origem desses conflitos de massa geradores de grande insatisfação popular, lembra Rodolfo de Camargo Mancuso também a responsabilidade do próprio Estado, sustentando que "a jurisdição coletiva em seu contexto geral apresenta-se, antes de mais nada, como um modo de ser do braço judiciário do Estado, voltada a dirimir conflitos de largo espectro, em grande parte motivados, ou pela inação/incompetência das instâncias administrativas que deveriam tê-los satisfatoriamente dirimido, ou pela oferta irregular/insuficiente das medidas e programas implementados. Por aí se compreende que a Jurisdição coletiva revela-se como um receptáculo de interesses e valores que, desatendidos ou mal manejados, vão aumentando a pressão social, operando assim a via judicial como uma sorte de válvula de escape, até porque as instâncias do Executivo e do Legislativo não são diretamente acionáveis pelo cidadão comum, tirante certos expedientes de eficácia demorada e incerta, como os projetos de lei de iniciativa popular, o plebiscito, as audiências públicas"114.

Outro aspecto a ser destacado é a motivação do causador da violação. Uma motivação torpe, como acontece com os danos causados a consumidores colocados em risco de morte por produtos fabricados sem a observância dos requisitos técnicos mínimos ${ }^{115}$, causa um sentimento de revolta generalizado, diante da percepção de que o causador agiu conscientemente, motivado tão-somente pela maximização ilícita de seus ganhos, configurando patente abuso do poder econômico ${ }^{116}$.

\footnotetext{
${ }^{114}$ Jurisdição coletiva e coisa julgada. São Paulo: Editora Revista dos Tribunais, 2007, p. 79.

${ }^{115}$ Exemplo dessa situação é o desabamento do edifício Palace II, na cidade do Rio de Janeiro, em 22/02/98, matando oito pessoas, resultado de erro de cálculo estrutural e uso de material de construção inadequado (Desabamento do Palace II completa dez anos; vítimas buscam indenização. Folha Online. Disponível em <www1.folha.uol.com.br/folha/cotidiano/ult95u374662.shtml>. Acesso em 31/07/2008). Rizzato Nunes, quando cita exemplos de direitos individuais homogêneos (As ações coletivas e as definições de direito difuso, coletivo e individual homogêneo. In: MAZZEI, Rodrigo; NOLASCO, Rita (coord.). Processo civil coletivo. São Paulo: Quartier Latin, 2005, p. 93), menciona casos semelhantes, como o da queda do avião da TAM, em São Paulo, em 31/10/96, causado por defeito mecânico (Queda do avião da TAM deixou 99 mortos há dez anos. Folha Online. Disponível em <www1.folha.uol.com.br/folha/cotidiano/ult95u126501.shtml>. Acesso em 31/07/2008), e do naufrágio do barco "Bateau Mouche" na Baía de Guanabara, Rio de Janeiro, em 31/12/88, motivado por superlotação e por uma reforma sem supervisão técnica (Memória: 55 pessoas morreram no Bateau Mouche. Globo Online. Disponível em <www.oglobo.globo.com/rio/mat/2006/10/16/286116874.asp>. Acesso em 31/07/2008).

${ }^{116}$ Sobre a proteção constitucional da defesa do consumidor e sua relação com o abuso de poder econômico, v. José Afonso da Silva, Curso de direito constitucional positivo. $19^{\mathrm{a}}$ ed. rev. atual. São Paulo: Malheiros, 2001, p. 265/266.
} 
$\mathrm{Na}$ maior parte das vezes, a violação é agravada pela circunstância de representar incentivo para outras violações e outras ilicitudes, de maneira a tornar ainda mais indispensável a repressão a essa atividade, uma das consequências do acesso dos lesados à justiça e, em especial, ao processo coletivo, diante das suas perspectivas de reparação global dos danos causados. Isso porque, se o causador do dano não se beneficiar dos ganhos auferidos em virtude da própria violação, não terá quaisquer outras vantagens; ao contrário, só terá prejuízos, diante da repercussão negativa geralmente a ela associada, de modo que a ilicitude deixará de representar vantagem. É o que ocorre, por exemplo, com a cobrança indevida de serviços não solicitados pelas companhias telefônicas (como taxas de religação de telefones e assinaturas de provedores de conteúdo para Internet). Nesses casos, ter de indenizar os prejuízos causados e ainda suportar os danos à imagem institucional provocados pelo seu próprio comportamento (além da divulgação da condenação judicial) é situação de desvalia suficiente para incentivar a observância dos direitos dos consumidores.

\subsection{3 - Remoção de obstáculos ao acesso à justiça}

Dentre os obstáculos ao acesso à justiça que a tutela de interesses individuais de forma coletiva é capaz de ultrapassar, destacam-se a hipossuficiência dos lesados, sua dispersão geográfica e a reduzida expressão econômica de cada violação individual.

Para além da vulnerabilidade de certas pessoas, colocadas em determinadas situações, como a posição de consumidor, algumas delas apresentam uma capacidade menor para defender os seus direitos, conforme explica Antonio Herman de Vasconcellos Benjamin ${ }^{117}$. Essa inferioridade em relação à outra parte na relação jurídica a ser levada a juízo, comprometendo a paridade de armas que deve presidir a relação jurídica processual, como projeção do princípio da isonomia real ${ }^{118}$, vem a ser a hipossuficiência. Sua principal manifestação, mas não a única, dá-se no plano econômico, ou seja, uma das partes possui reduzida capacidade econômica, se comparada com a do seu adversário. É o

\footnotetext{
117 In: GRINOVER, Ada Pellegrini et al. Código brasileiro de defesa do consumidor comentado pelos autores do anteprojeto. $5^{\mathrm{a}}$ ed. rev. atual. amp. Rio de Janeiro: Forense Universitária, 1998, p. 300.

${ }^{118}$ V. Nelson Nery Júnior, Princípios do processo civil na constituição federal. $8^{\mathrm{a}}$ ed. São Paulo: Editora Revista dos Tribunais, 2004, p. 72/73.
} 
caso do consumidor pobre, para quem pode ser mais difícil provar a sua alegação do que o fornecedor provar a dele; nesse caso, tal consumidor pode contar com o benefício legal da inversão do ônus probatório (art. $6^{\circ}$, inciso VIII, do CPC) ${ }^{119}$.

A hipossuficiência também pode ser técnica, isto é, uma das partes pode ter um domínio muito maior do que a outra sobre as informações relativas aos acontecimentos que envolvem a demanda. As partes podem ter capacidades econômicas até mesmo semelhantes, mas uma delas domina os dados que caracterizam os fatos litigiosos. É o caso da fabricante de máquinas de hemodiálise, possuidora de condições mais favoráveis de provar a ausência de defeito no seu produto do que a associação de consumidores de demonstrar a existência de defeito.

A hipossuficiência cultural consiste na condição daqueles que não têm possibilidades de reconhecer os seus direitos ou não dispõem de conhecimento sobre as providências necessárias para propor uma demanda, ou ainda não têm disposição psicológica para recorrer ao Poder Judiciário. Muitas pessoas não sabem que estão em situação de sujeitar outras pessoas ao seu interesse, porque o ordenamento jurídico dispõe de regramento nesse sentido; outras nem mesmo sabem que precisam, como regra, recorrer a um advogado para obter aconselhamento jurídico e poder ingressar em juízo; e outras ainda apresentam grande aversão ao ambiente formalista e intimidador dos tribunais, antipatia aos profissionais do Direito (advogados, juízes, oficiais de justiça etc.) e repulsa aos procedimentos judiciais complexos. Pesquisas demonstram que esses fatores

\footnotetext{
${ }^{119}$ Importante distinguir o ônus da prova das obrigações relacionadas à produção da prova. A simples falta de recursos econômicos do hipossuficiente para produzir a prova não implica a necessidade de inversão do ônus da prova, sendo suficiente a inversão da obrigação de suportar as despesas processuais correspondentes, com base no princípio da isonomia (arts. 19 e 125, inciso I, do CPC).

Da mesma forma, a mera falta de condições do consumidor hipossuficiente de produzir a prova sem se utilizar de documento ou coisa que esteja na posse do fornecedor não exige a inversão do ônus probatório, bastando a requisição judicial ao segundo sob pena de presumirem-se verdadeiros os fatos que por esse meio o primeiro pretendia provar (art. 359 do CPC). Nesse caso, se apresentado o documento ou coisa, o ônus probatório continuará a ser do consumidor, que terá de provar suas alegações, ainda que facilitado pela apresentação determinada pelo juiz.
}

Além disso, existe uma corrente doutrinária no sentido de que as normas de distribuição do ônus da prova consistem em regras de julgamento, não de ordenação da fase probatória, devendo a inversão ocorrer apenas no momento da prolação da sentença, sem que isso implique qualquer cerceamento do direito de defesa (V. Kazuo Watanabe, In: GRINOVER, Ada Pellegrini et al. Código brasileiro de defesa do consumidor comentado pelos autores do anteprojeto. $5^{\mathrm{a}}$ ed. rev. atual. amp. Rio de Janeiro: Forense Universitária, 1998, p. 619). 
representam importante obstáculo ao acesso à justiça ${ }^{120}$, incidindo com muita frequência na situação de consumidores lesados, por exemplo ${ }^{121}$.

Decorre das próprias características dos interesses individuais homogêneos, desprovidos de relação jurídica base entre os interessados e derivados de uma causa comum, outra dificuldade para o acesso dos lesados à tutela jurisdicional, ou seja, a sua dispersão territorial. Como os interessados não são previamente ligados por circunstâncias jurídicas ou de fato, é comum que estejam distribuídos por toda a área sobre a qual a causa comum foi capaz de emanar efeitos, muitas vezes uma área de grandes dimensões, algumas vezes englobando toda uma região do país ou mesmo o país inteiro. Por exemplo, o descumprimento de cláusula de contrato de conta-corrente por instituição bancária de atuação nacional origina interesses individuais homogêneos de inúmeras pessoas espalhadas por todo o país. Dispersos assim, esses indivíduos não terão meios nem sequer de se conhecer, muito menos de se reunir ou de articular uma estratégia única para defesa dos seus interesses ${ }^{122}$.

Por fim, a existência de lesões individuais de pequeno porte, mas que representam, no conjunto, um dano de grande extensão, impedem o acesso à justiça de titulares de interesses individuais homogêneos, considerando que a demanda individual pode ser desvantajosa para cada lesado, especialmente se a comprovação de suas alegações for trabalhosa ${ }^{123}$. Além disso, terá contra si, certamente, todo o empenho do infrator num eventual litígio, visando impedir uma vitória que poderia servir de incentivo para os demais lesados ${ }^{124}$.

\footnotetext{
${ }^{120}$ V. Mauro Cappelletti e Bryant Garth, Acesso à justiça. Porto Alegre: Sergio Antonio Fabris Editor, 1988, p. $22 / 25$.

${ }^{121}$ V. Antonio Herman Vasconcellos Benjamin, que divide os obstáculos ao acesso à justiça em, de um lado, barreiras objetivas, práticas ou econômicas, e de outro, barreiras subjetivas, psicológicas ou culturais (A Insurreição da Aldeia Global contra o Processo Civil Clássico: apontamentos sobre a opressão e a libertação judiciais do meio ambiente e do consumidor, p. 43. Biblioteca Digital do Superior Tribunal de Justiça, disponível em <http://bdjur.stj.gov.br/dspace/handle/2011/8688>. Acesso em 30/10/2008).

${ }^{122}$ V. Mauro Cappelletti e Bryant Garth, Acesso à justiça. Porto Alegre: Sergio Antonio Fabris Editor, 1988, p. 26.

${ }^{123}$ V. André Ramos Tavares, Apontamentos acerca do princípio constitucional do acesso à justiça. In: Boletim Científico da Escola Superior do Ministério Público da União, ESMPU, Ano II, n. 6, Brasília, jan./mar. 2003.

${ }^{124}$ V. Antonio Herman Vasconcellos Benjamim, A Insurreição da Aldeia Global contra o Processo Civil Clássico: apontamentos sobre a opressão e a libertação judiciais do meio ambiente e do consumidor, p. 46. Biblioteca Digital do Superior Tribunal de Justiça, disponível em <http://bdjur.stj.gov.br/dspace/handle/2011/8688>, acesso em 30/10/2008.
} 
Ainda que algum dos interessados tome a iniciativa de propor a demanda, individualmente, só os danos suportados poderão ser exigidos, nunca os danos causados a todos os lesados, o que retira a capacidade de a ação persuadir o réu a cessar a conduta lesiva. Em consequência, poderá haver indenização do prejuízo individual, mas não do prejuízo total provocado, nem se evitará a ocorrência de novos danos no futuro ${ }^{125}$.

É o que ocorre, por exemplo, com o fabricante de farinha de trigo que vende embalagens indicando conteúdo de um quilograma mas pesando, na verdade, vinte gramas a menos, lesando consumidores individuais em poucos centavos, mas obtendo ganho ilícito expressivo quando considerada a venda total mensal, muitas vezes de dezenas ou centenas de milhares de unidades. Nenhum consumidor assumirá, individualmente, uma demanda tão antieconômica; e ainda que algum deles propusesse a demanda individual, isso de nada serviria para impedir o prosseguimento da lesão, gerando mais interesses individuais homogêneos dos compradores do produto, cuja relevância decorre dos prejuízos globalmente causados.

\subsection{4 - Critérios para aferição da conveniência}

Quando se analisa a questão da conveniência da tutela coletiva, a primeira impressão é a da inexistência de regras objetivas para definir pela sua presença ou ausência em determinada situação. A própria noção de conveniência remete à ideia de apreciação subjetiva, ainda que aqui não se trate de discricionariedade.

Mas a conveniência, como mostrado acima, deve ser entendida do ponto de vista do acesso à justiça e da efetividade do processo, isto é, a tutela coletiva será conveniente se consistir na forma de tutela jurisdicional mais eficaz para permitir ao cidadão obter o bem da vida objeto do seu interesse.

Alguns parâmetros, porém, podem ser fixados para definir se determinados interesses individuais homogêneos são relevantes o bastante para impor tratamento coletivo, com base nas mesmas ideias expostas neste capítulo.

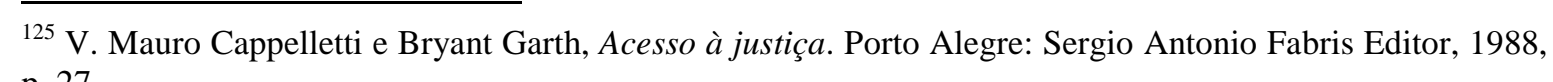
p. 27. 
Em primeiro lugar, todos os interesses relevantes requerem a tutela jurisdicional da forma mais eficaz; sendo possível e útil a tutela coletiva, ela deverá ser considerada também a mais conveniente. Isso inclui todos os direitos constitucionalmente garantidos ou legalmente indisponíveis, bem como todas as violações graves de direitos que gerem interesses individuais homogêneos, conforme mencionado no tópico relativo à relevância do bem jurídico tutelado e da sua violação (item 3.4.2, supra).

Em segundo lugar, ainda que não se trate de direitos constitucionalmente protegidos, indisponíveis ou cuja violação apresente especial gravidade, existirá a conveniência da tutela coletiva de quaisquer interesses individuais homogêneos que, por sua própria natureza, encontrem consideráveis barreiras ao acesso à justiça, as quais possam ser afastadas pela tutela coletiva. Trata-se, nesse caso, de interpretar a legislação processual no sentido de assegurar o respeito à garantia constitucional da inafastabilidade da jurisdição ${ }^{126}$, ou seja, se a limitação da tutela de determinados interesses ao processo individual resultar no impedimento do acesso à justiça, impor-se-á então a abertura da via processual coletiva, que não deve ser obstada.

Um último critério, a ser utilizado quando a relevância do bem ou da violação não fiquem claramente configuradas ou quando as barreiras ao acesso à justiça não podem ser consideradas intransponíveis, deve ser o da primazia da tutela coletiva, vale dizer, deve-se considerar preferível esse tipo de tutela. Isso pode ocorrer seja porque a conveniência ainda não está clara no momento da propositura da ação (muitas vezes só possível de ser avaliada na fase probatória), seja porque a superioridade da tutela coletiva não é evidente.

Em qualquer dos casos, a preferência pela via coletiva se justifica em razão das enormes vantagens da molecularização dos conflitos, propiciada pela ação coletiva, servindo melhor aos princípios da inafastabilidade e da efetividade da tutela jurisdicional. Dificilmente, numa situação limítrofe, a opção pela ação coletiva se revelará menos efetiva ou vantajosa para os proponentes, sem falar nas vantagens para os próprios órgãos da jurisdição, cujas pautas facilmente são obstruídas pela disseminação de causas repetitivas.

${ }^{126}$ Art. $5^{\circ}$, inciso XXXV. 


\title{
CAPÍTULO 4 - AS DIFICULDADES DA TUTELA JURISDICIONAL DOS INTERESSES INDIVIDUAIS HOMOGÊNEOS
}

\begin{abstract}
4.1 - Do litisconsórcio à tutela coletiva de interesses individuais homogêneos; 4.2 - Uma breve visão histórico-comparativa; 4.2.1 A "class action"; 4.2.2 - A Lei da Ação Civil Pública e o Código de Defesa do Consumidor; 4.3 - Problemas antigos e a legislação vigente; 4.3.1 - A representação dos ausentes; 4.3.2 - Os limites subjetivos da coisa julgada coletiva; 4.3.3 - A resistência do Poder Executivo à tutela coletiva; 4.4 - Problemas atuais e as propostas de "lege ferenda"; 4.4.1 - As propostas de Código de Processo Coletivo e suas inovações; 4.4.2 - Os problemas atuais e as soluções propostas.
\end{abstract}

4.1 - Do litisconsórcio à tutela coletiva de interesses individuais homogêneos

A defesa de interesses decorrentes de origem comum, como são os interesses individuais homogêneos, também pode ser exercida no regime do Código de Processo Civil. Nos termos do estatuto processual, através do litisconsórcio, “duas ou mais pessoas podem litigar, no mesmo processo, em conjunto, ativa ou passivamente", entre outras hipóteses quando "os direitos ou as obrigações derivarem do mesmo fundamento de fato ou de direito" ou quando "ocorrer afinidade de questões por um ponto comum de fato ou de direito" 127 . Se considerarmos que "fundamento de fato" ou "ponto de fato" são expressões equivalentes a origem comum, a hipótese legal contempla precisamente os interesses individuais homogêneos ${ }^{128}$.

O litisconsórcio é caracterizado pela pluralidade de partes, simplesmente, ou seja, pela presença de duas ou mais pessoas no polo ativo ou no polo passivo ou em ambos; eventual é a comunhão de sortes, como o nome do fenômeno processual sugere, ou seja, ainda que as partes estejam no mesmo lado da contenda, poderão não obter tutelas iguais, podendo algumas obter tutelas diversas (sentença de procedência integral ou parcial) e outras, tutela alguma (sentença de improcedência) ${ }^{129}$.

\footnotetext{
${ }^{127}$ Art. 46, incisos II e IV, do CPC.

${ }^{128}$ Nesse sentido, Teori Albino Zavascki (Processo Coletivo - Tutela de direitos coletivos e tutela coletiva de direitos. $2^{\mathrm{a}}$ ed. rev. atual. São Paulo: Editora Revista dos Tribunais, 2007, p. 161-166).

${ }^{129}$ V. Cândido Rangel Dinamarco, Litisconsórcio. $7^{\mathrm{a}}$ ed. rev. atual. amp. São Paulo: Malheiros, 2002, p. 3943.
} 
Embora o litisconsórcio constitua uma cumulação de sujeitos processuais, de caráter subjetivo, portanto, é inegável que a ela corresponde também uma cumulação objetiva, quer dizer, uma reunião, pelo menos formal, de demandas de cada um dos litisconsortes ${ }^{130}$. Essas demandas podem estar identificadas numa só (cúmulo objetivo meramente formal) ou constituírem demandas diferenciadas (cúmulo objetivo material): no primeiro caso, quanto ao resultado, temos hipótese de litisconsórcio unitário, no qual a sentença há de ser única em face de todos os litisconsortes presentes, seja de procedência ou de improcedência; no segundo caso, o litisconsórcio é comum ou simples, isto é, a sentença não apresentará, necessariamente, uma homogeneidade em relação a todos os sujeitos que buscaram a tutela jurisdicional.

Quando a decisão não precisa ser uniforme, o litisconsórcio não precisa incluir todos os sujeitos da relação jurídica de direito material objeto da demanda, classificando-se, quanto à formação, como facultativo. Caso contrário, devendo a sentença ser subjetivamente igual em face de todos, para que ela adquira também efetividade, o litisconsórcio, sendo unitário quanto ao resultado, deve ser formado, como regra, por todas as pessoas cotitulares do direito material discutido, configurando-se necessário quanto à formação.

A razão é que determinadas relações jurídicas de direito material não comportam cisão, devendo ser decididas igualmente em relação a todos os seus participantes. Em consequência, a solução do litígio, para ser integral e definitiva, principal escopo social do processo $^{131}$, deve ser não apenas unitária em relação a todos os interessados, mas também deve projetar sobre eles todos os seus efeitos e a sua definitividade. Se não se trata de relação jurídica incindível, ao contrário, então não há razão para condicionar a efetividade da sentença à presença de qualquer outra pessoa que não aquela que inicialmente tomou a iniciativa de recorrer ao Poder Judiciário. Não é por outra razão que em outros ordenamentos jurídicos não se faz distinção entre unitariedade e

\footnotetext{
${ }^{130}$ Cândido Rangel Dinamarco lembra a distinção entre ação (poder de postular em juízo) e demanda (ato de fazê-lo), preferindo falar em cúmulo de demandas, e leciona que "o cúmulo subjetivo de demandas, quando se pensa em cúmulo substancial e jurídico e não apenas cúmulo formal, não é hipótese que se contraponha simetricamente à de cúmulo objetivo, uma vez que não se podem conceber demandas subjetivamente cumuladas sem que objetivamente também o sejam. Todo cúmulo subjetivo tem por substrato um cúmulo objetivo e inexiste sem ele"; "a recíproca não é verdadeira: é até corriqueiro o cúmulo objetivo entre duas partes apenas" (Litisconsórcio. $7^{\mathrm{a}}$ ed. rev. atual. amp. São Paulo: Malheiros, 2002, p. 72 e 76 ).

${ }^{131}$ V. Cândido Rangel Dinamarco, Instrumentalidade do processo. $13^{\mathrm{a}}$ ed. rev. atual. São Paulo: Malheiros, 2008, p. 188-191.
} 
necessariedade do litisconsórcio, como na Itália e na Alemanha ${ }^{132}$, assim como essa é causa da confusão de conceitos que acabou sendo feita na própria legislação brasileira, na qual o litisconsórcio necessário é definido com a noção do litisconsórcio unitário ${ }^{133}$.

Assim é, como regra: se o litisconsórcio é unitário, também será necessário ${ }^{134}$. Mas há exceções.

Por vezes, o legislador, a partir de motivações de natureza política (como a necessidade de encerrar conflitos em temas sensíveis, como a propriedade imóvel, ou de proteger o patrimônio familiar etc.), impõe a necessidade de formação de litisconsórcio mesmo na ausência de relação jurídica substancial incindível, resultando um litisconsórcio comum necessário. A doutrina aponta o exemplo do usucapião ${ }^{135}$, no qual a citação de todos os confinantes deve ser promovida pelo autor ${ }^{136}$, ou o das ações que possam onerar o patrimônio do casal ${ }^{137}$.

Outras vezes o legislador, também a partir de considerações de cunho político (por exemplo, a garantia do acesso à justiça, a tutela de direitos especialmente relevantes etc.), permite a propositura de ação sem formação de litisconsórcio para a discussão de relação jurídica incindível, instituindo, para o caso, um litisconsórcio unitário facultativo. É como ocorre nos casos de ação reivindicatória movida por condômino ou de ação anulatória de deliberação de assembleia de sociedade anônima ajuizada por qualquer acionista, nos quais todos os titulares do direito litigioso não presentes em juízo se submeterão aos efeitos da sentença, mas não da coisa julgada que vier a ser formada ${ }^{138}$.

Mas o processo que contempla um litisconsórcio não constitui jurisdição coletiva por causa disso. A pluralidade de partes, por si só, não induz o caráter coletivo ao

${ }^{132}$ V. Cândido Rangel Dinamarco, Litisconsórcio. $7^{\mathrm{a}}$ ed. rev. atual. amp. São Paulo: Malheiros, 2002, p. 119120.

133 Art. 47 do CPC.

${ }^{134}$ Cândido Rangel Dinamarco leciona que a unitariedade e a necessariedade são dois efeitos da mesma causa: a natureza especial da relação jurídica controvertida no processo (Litisconsórcio. $7^{\mathrm{a}}$ ed. rev. atual. amp. São Paulo: Malheiros, 2002, p. 160).

135 Art. 942 do CPC.

${ }^{136}$ V. Nelson Nery Júnior e Rosa Maria de Andrade Nery, Código de processo civil comentado e legislação extravagante. $7^{\text {a }}$ ed. rev. amp. São Paulo: Editora Revista dos Tribunais, 2003, p. 416.

${ }^{137}$ Art. 10, parágrafo $1^{\circ}$, do CPC.

${ }^{138}$ V. José Roberto dos Santos Bedaque (In: MARCATO, Antonio Carlos (coord.). Código de processo civil interpretado. $2^{\mathrm{a}}$ ed. São Paulo: Atlas, 2005, p. 154). 
processo. Rodolfo de Camargo Mancuso leciona que processo coletivo não é aquele em que os interesses individuais estejam apenas somados ou aquele onde não predominem os elementos comuns, mas aquele por meio do qual "uma certa faixa do universo coletivo irá receber a projeção da eficácia do comando judicial, indistintamente, pois, de quem sejam os sujeitos concernentes" $" 139$.

No litisconsórcio ativo, os interesses são somados, no sentido de que o pedido é resultado da soma dos pedidos de cada autor litisconsorciado. No processo coletivo, ao contrário, o pedido é uma síntese dos pedidos das partes, isto é, o reconhecimento judicial buscado é aquele referente ao denominador comum dos interesses de todos os indivíduos, a parte genuinamente coletiva, dizendo respeito a todos, dos interesses a serem defendidos ${ }^{140}$.

Ao mesmo tempo, a sentença coletiva fará coisa julgada não apenas em face das partes efetivamente presentes na lide, mas em relação a todos os interessados. No litisconsórcio, por sua vez, tratando-se de jurisdição singular, a sentença só produzirá efeitos em relação às partes, ou seja, os litisconsortes e a parte contrária, nos termos do art. 472 do $\mathrm{CPC}^{141}$.

Por essas razões, por constituir uma soma de pedidos e só projetar efeitos sobre as partes, o litisconsórcio constitui uma solução limitada para a tutela dos interesses individuais homogêneos. Em primeiro lugar, porque, se todos os interessados estão presentes, todas as questões necessárias à configuração completa da obrigação a ser imposta ao réu devem ser colocadas, discutidas e decididas, não apenas aquelas decorrentes da origem comum, mas também as resultantes das individualidades de cada autor. Em segundo lugar, porque, como consequência, o pedido e a sentença deverão ser individualizados, contemplando todas as particularidades de cada interessado.

\footnotetext{
139 Jurisdição coletiva e coisa julgada. São Paulo: Editora Revista dos Tribunais, 2007, p. 61.

${ }^{140}$ Rodolfo de Camargo Mancuso refere o surgimento de um "fenômeno coletivo", "o interesse coletivo no seu sentido próprio, porque, conquanto originário dos interesses individuais, representa a síntese, um amálgama daqueles; a partir desse momento, se desvanecem os interesse individuais originários, surgindo uma nova realidade: a dos interesses (verdadeiramente) coletivos" (Interesses difusos. $6^{\mathrm{a}}$ ed. rev. atual. amp. São Paulo: Editora Revista dos Tribunais, 2004, p. 55).

141 “A sentença faz coisa julgada às partes entre as quais é dada, não beneficiando, nem prejudicando terceiros. Nas causas relativas ao estado de pessoa, se houverem sido citados no processo, em litisconsórcio necessário, todos os interessados, a sentença produz coisa julgada em relação a terceiros."
} 
Pode-se imaginar, tratando-se de uma violação de massa, a complexidade de um processo assim, com dezenas, centenas ou milhares de autores discutindo uma relação jurídica comum, decorrente da identidade do fundamento de fato, mas também litigando a propósito de uma infinidade de questões relativas a cada situação individual. Daí surge a necessidade de um processo verdadeiramente coletivo, que acolha, de uma só vez, todos esses interessados, ainda que para decidir apenas o que de coletivo houver na demanda.

Ganha-se de um lado e perde-se de outro. Na tutela individual, por meio de litisconsórcio, é possível discutir e pleitear a prestação necessária para a obtenção do bem da vida de forma completa, sem a necessidade de qualquer liquidação posterior, mas o número de interessados não pode ser excessivamente grande, para que todos possam estar presentes em juízo e todas as questões individuais possam ser discutidas. Na tutela coletiva, não é possível discutir todas as questões, mas tão-somente o núcleo comum dos interesses individuais tutelados; por outro lado, o número de interessados é ilimitado, dispensando-se a presença de todos eles em juízo, bastando estarem adequadamente representados.

Mas entre esses dois extremos, existirá um ponto de inflexão, uma determinada situação a partir da qual o processo individual via litisconsórcio deixe de ser possível, tornando imperativa a coletivização da demanda? Do ponto de vista quantitativo, quando nasce a necessidade de tutela coletiva de interesses individuais homogêneos?

O legislador, ao disciplinar o litisconsórcio, impôs uma limitação que joga luzes nessa questão, ou seja, "o juiz poderá limitar o litisconsórcio facultativo quanto ao número de litigantes, quando este comprometer a rápida solução do litígio ou dificultar a defesa. $O$ pedido de limitação interrompe o prazo para resposta, que recomeça da intimação da decisão"142. A limitação só se refere ao litisconsórcio facultativo porque seria incompatível com o litisconsórcio necessário ${ }^{143}$, no qual a lei exige a presença em juízo de todos os interessados (ou, para ser mais preciso, a sua citação).

\footnotetext{
${ }^{142}$ Parágrafo único do art. 46 do CPC.

143 Art. 47 do CPC ("Há litisconsórcio necessário, quando, por disposição de lei ou pela natureza da relação jurídica, o juiz tiver de decidir a lide de modo uniforme para todas as partes; caso em que a eficácia da sentença dependerá da citação de todos os litisconsortes no processo."). O dispositivo, conforme doutrina unânime, contém impropriedade técnica, ao definir litisconsórcio necessário utilizando-se da noção de
} 
O número máximo de litigantes, na prática judiciária, não costuma ultrapassar dez autores, uma vez que, nessas condições, a lide já pode tornar-se bastante complexa e de lenta tramitação. Essa circunstância, de que o número de litigantes na jurisdição singular é diretamente proporcional à complexidade que a demanda adquire, bem como à quantidade de questões a serem discutidas e decididas e à quantidade de provas a serem produzidas, faz pensar que essa complexidade crescente é o único dado decisivo para determinar o momento genético da tutela coletiva de interesses individuais homogêneos.

Mas o que torna complexo o processo individual no qual se forma litisconsórcio (e tanto mais complexo quanto maior for o litisconsórcio) não é unicamente a quantidade de questões individuais a serem debatidas ou as provas a serem produzidas para demonstração das alegações individuais. O próprio modo de ser do processo individual exige a participação de todas as partes, no sentido de que têm elas o direito de ser intimadas de todos os atos judiciais, direito ao contraditório, de participação nas audiências, por exemplo. Somente a efetivação dessas faculdades processuais já torna complexo o processo, exatamente na medida do número de integrantes do polo ativo (ou passivo).

Quanto ao número, é impossível determinar uma quantidade máxima de litigantes a partir do qual a demanda na jurisdição singular deixa de ser viável, mesmo porque as dificuldades da demanda dependem de cada caso, tanto em termos de matéria controvertida, quanto de provas a serem produzidas. Além disso, poderá haver demandas em que inexistirão questões individuais, ou seja, nas quais não há necessidade de definir a identidade dos credores e/ou o valor da prestação, ou ainda situações de dispensa da fase executiva, como nas sentenças declaratórias ou constitutivas. Considerando tudo isso, caberá ao juiz decidir o número de litigantes a partir do qual o processo individual em

litisconsórcio unitário: é neste último que a decisão precisa ser uniforme para todas as partes. Não se trata de expressões sinônimas. Pode haver litisconsórcio unitário necessário ou facultativo, assim como litisconsórcio comum necessário ou facultativo.

O litisconsórcio necessário exige a citação de todos os litisconsortes não porque a decisão tenha de ser uniforme (se o litisconsórcio não for também unitário, ela poderá não ser), mas porque a efetividade da decisão em relação a cada um depende da existência de decisão, favorável ou desfavorável, em relação a todos. Na ação de usucapião, exemplo de litisconsórcio comum necessário, todos os confrontantes devem ser citados, porque a questão (aquisição da propriedade) deve ser decidida em relação a todos, pois precisa vincular todos, mas não precisa ser uniforme (alguns confrontantes que se opuserem poderão ser beneficiados, outros não). 
litisconsórcio torna-se inviável, cabendo a limitação legal para o fim de dividir o processo em tantos feitos quantos forem necessários para permitir a sua tramitação em modo e tempo razoáveis ${ }^{144}$.

Mas isso ainda não conduzirá à jurisdição coletiva. A autorização legal para a limitação do número de litisconsortes, na verdade, conduz não ao processo coletivo, mas à multiplicação de processos individuais em litisconsórcios, agora com menos autores.

Isso faz pensar que toda situação de cabimento da limitação do litisconsórcio é também justificadora de coletivização da demanda. É preciso ter em mente que o próprio litisconsórcio já constitui uma técnica de economia processual, na medida em que decide vários litígios num único processo ${ }^{145}$. Ora, natural que, à medida que o aumento do número de partes torna o processo muito complexo e, ao invés de facilitar a tutela jurisdicional vai acabar por inviabilizá-la, outra solução ainda mais conveniente deva ser a recomendável.

Nesse contexto, a utilização de diversos litisconsórcios limitados constitui solução apenas se e quando a tutela coletiva for incabível. A ação coletiva deve ser preferida sempre que, sendo necessária a limitação do litisconsórcio, estiverem presentes os requisitos da tutela coletiva.

Analisemos então as possibilidades. Se o litisconsórcio for comum, seja facultativo ou necessário, indiferentemente, a homogeneidade poderá estar presente ou não, dependendo de a relação jurídica que ampara os interesses a serem tutelados exibir ou não o núcleo de homogeneidade exigido, ou seja, a mesma obrigação, o mesmo devedor e a mesma natureza da prestação. Sendo cabível a tutela coletiva, ela será, sem dúvida, a melhor alternativa, ainda que não a única.

Por exemplo, funcionários públicos poderão formar um litisconsórcio para pleitear a reposição de perdas vencimentais em face do órgão público que não teria cumprido a lei no tocante ao reconhecimento de alguma vantagem pecuniária; mas,

\footnotetext{
${ }^{144}$ Quanto ao número mínimo legalmente admissível de interessados para admissão da ação coletiva para tutela de interesses individuais homogêneos, Vicente Greco Filho entende que bastam dois, na ausência de limitação legal (In: OLIVEIRA, Juarez de (coord.), Comentários ao Código de Proteção ao Consumidor. São Paulo: Saraiva, 1991, p. 366).

${ }^{145}$ V. José Roberto dos Santos Bedaque (In: MARCATO, Antonio Carlos (coord.). Código de processo civil interpretado. $2^{\mathrm{a}}$ ed. São Paulo: Atlas, 2005, p. 152).
} 
tratando-se de interesses individuais homogêneos, uma associação de servidores poderia ajuizar uma ação coletiva com esse mesmo propósito, cuja sentença, caso procedente, viria a ser liquidada e executada por cada associado que se enquadrasse naquela hipótese, apurando-se a identidade de cada credor e os valores devidos a cada um deles. Ao mesmo tempo, seria possível que mutuários de determinada carteira de financiamento habitacional formassem um litisconsórcio, para pedir a nulidade dos idênticos contratos assinados por todos eles, alguns alegando inclusão de cláusula abusiva, outros sustentando vício de consentimento, diante da conexão das causas pelo objeto ${ }^{146}$; mas não seria possível a propositura de uma ação coletiva, porque a sentença genérica é inviável, considerando que, se procedente o pedido, a tutela para alguns será a modificação das obrigações contratuais, enquanto para outros será a rescisão do contrato, com apuração de perdas e danos.

Por outro lado, se o caso é de litisconsórcio unitário, seja facultativo ou necessário, indiferentemente, os interesses individuais dos litisconsortes serão sempre homogêneos. É o que ocorre nos casos de incindibilidade da relação jurídica objeto do processo, como ocorre na ação de dissolução de sociedade anônima, por exemplo ${ }^{147}$.

Tratando-se de litisconsórcio unitário, se a tutela coletiva for cabível, além de ser a melhor alternativa, em teoria, poderá ser também uma solução para o problema prático da formação do litisconsórcio de multidões, isto é, a impossibilidade de administração de um processo com um número muito grande de litigantes. Se o litisconsórcio for unitário e facultativo, a tutela coletiva será a melhor solução para o problema se este vier a se apresentar, ou seja, se muitos interessados acorrerem ao Poder Judiciário na jurisdição singular em litisconsórcio ou, mais ainda, caso optem pela via individual.

Mas se o litisconsórcio for unitário e necessário, a tutela coletiva será a única solução para o problema, permitindo um processo administrável pelo menos até a sentença genérica, ainda que seja inevitável a fase individual quando da liquidação e execução, que então poderá dar-se na forma de litisconsórcio em grupos de interessados em situação mais assemelhada. Isso porque, na via coletiva, a simples presença em juízo do autor coletivo basta para representar o grupo e vincular todos os seus membros, à

\footnotetext{
146 Art. 46, inciso III, do Código de Processo Civil.

${ }^{147}$ O exemplo é retirado da casuística citada por Cândido Rangel Dinamarco (Litisconsórcio. $7^{\mathrm{a}}$ ed. rev. atual. amp. São Paulo: Malheiros, 2002, p. 167 e nota n. 101).
} 
definitividade da sentença que vier a ser proferida, mesmo os ausentes, embora, no sistema brasileiro, essa vinculação fique restrita ao plano processual coletivo.

Na prática, porém, não é hipótese comum: os casos de litisconsórcio unitário são franca minoria, mais ainda os de litisconsórcio unitário multitudinário ${ }^{148}$. A aplicação prática mais comum parece ser a tutela de interesses individuais homogêneos de natureza declaratória ou mandamental, que poderiam colocar o réu em situação de obrigação de adotar posturas incompatíveis, caso fossem propostas diversas ações individuais julgadas diferentemente ${ }^{149}$. Porém também não é hipótese comum, porque não basta uma contradição lógica entre os julgados, é preciso haver uma contradição prática ${ }^{150}$. Seria necessário que o pedido individual implicasse em ordem para que o réu agisse de modo homogêneo em relação a todos, para que outra ordem determinando conduta diversa originasse um verdadeiro dilema. Por exemplo, se uma ação individual pleiteasse a fixação de dividendos, pagos por uma companhia a seus sócios, no valor "x" e outra pleiteasse a fixação de dividendos no valor “y”. Ocorre que, em princípio, não haveria legitimidade de cada sócio para postular esse tipo de tutela em favor de todos na jurisdição singular.

Naturalmente, toda essa avaliação da conveniência da via coletiva pode e deve ser feita pelas partes, ainda mais que os interessados estarão atuando suficientemente coordenados para pensar em propor a demanda em litisconsórcio. Se o processo individual litisconsorciado se revela inviável, são eles, os autores que buscam a tutela de interesses decorrentes dos mesmos fundamentos, os maiores interessados em utilizar-se da via coletiva, por exemplo, mediante a instituição ou a adesão a uma associação cujo objeto guarde pertinência com a causa.

\footnotetext{
148 Felizmente, considerando que o litisconsórcio unitário sempre constitui um problema para regular a formação da relação jurídica processual, especialmente se for ativo. Tanto isso é verdade que não há lei determinando que qualquer causa seja decidida de modo uniforme; a unitariedade é um mal necessário, decorrente apenas da natureza da relação jurídica material (v. Cândido Rangel Dinamarco, Litisconsórcio. $7^{\mathrm{a}}$ ed. rev. atual. amp. São Paulo: Malheiros, 2002, p. 140).

149 Uma das espécies de ação coletiva no sistema norte-americano contempla justamente a hipótese de litisconsórcio unitário tão numeroso que pode chegar a tornar inviável o processo na jurisdição singular. É a "incompatible standarts class action", prevista na Rule 23 (b) (1) (A) das "Federal Rules of Civil Procedure" (v. o próximo item deste capítulo).

${ }^{150}$ Antonio Gidi explica que esse é o entendimento, um tanto restritivo, da jurisprudência norte-americana no tocante à aceitação das "incompatible standarts class action" (A class action como instrumento de tutela coletiva dos direitos. São Paulo: Editora Revista dos Tribunais, 2007, p. 148-150).
} 
Além disso, como a limitação nem sequer se aplica na hipótese de litisconsórcio necessário, as situações de complexidade da demanda, capazes de inviabilizar a via individual em litisconsórcio necessário, devem ser suficientes para determinar a utilização do processo coletivo. Em ambos os casos, porém, a coletivização da demanda ainda depende dos próprios autores, uma vez que o juiz só poderá, quando muito, desdobrar a demanda em vários processos, dividindo o litisconsórcio inicial em outros, menores ${ }^{151}$.

\section{2 - Uma breve visão histórico-comparativa}

\subsection{1 - A class action}

Um ordenamento jurídico com rica experiência em ações coletivas é o dos Estados Unidos da América. Não por outra razão, foi lá que o legislador brasileiro buscou inspiração e modelo para a regulação do processo coletivo nacional ${ }^{152}$, particularmente no tema dos interesses individuais homogêneos. Por essa razão, é indispensável destacar os pontos mais relevantes num estudo como este, mesmo que sem descrever pormenorizadamente as peculiaridades de um sistema de origens e características tão diferentes do nosso como é o da common law.

As ações coletivas do Direito anglo-saxão existem há pelo menos oito séculos ${ }^{153}$, ainda que nem sempre pudessem ser consideradas efetivamente coletivas pelos critérios modernos, especialmente a necessidade da presença em juízo de todos os interessados e a ausência de extensão dos efeitos da coisa julgada sobre os ausentes. Na verdade, na Idade Média, não havia ainda o conceito de personalidade jurídica, de modo que nem sequer era possível cogitar de alguém estar sendo representado por outra pessoa; a legitimidade ordinária era a regra absoluta.

\footnotetext{
${ }^{151}$ A questão da coletivização da demanda por iniciativa judicial será tratada neste mesmo capítulo, no item 4.4.2.

${ }^{152}$ Nesse sentido, Pedro Lenza, Teoria geral da ação civil pública. São Paulo: Editora Revista dos Tribunais, 2003, p. 161.

${ }^{153}$ V. Luiz Paulo da Silva Araújo Filho (Ações coletivas: a tutela jurisdicional dos direitos individuais homogêneos. Rio de Janeiro: Forense, 2000, p. 18).
} 
Seja como for, as ações judiciais de grupos ou contra eles (group litigation) têm longa tradição no Direito inglês. A sua origem está ligada ao sistema da equity, conjunto de regras jurídicas, processuais e materiais que, naquele ordenamento jurídico, funciona paralela e complementarmente ao sistema da common law e apresenta bem mais flexibilidade em comparação com este ${ }^{154}$.

Assim, foram os tribunais de equidade que passaram a permitir a representação de grupos grandes por meio de representantes, as representative actions ${ }^{155}$, especialmente para resolver os problemas consistentes na impossibilidade de todos os interessados estarem em juízo, exigência pelas regras do sistema da common law, e de evitar o trabalho inútil de ações repetidas e o dispêndio de recursos que isso exigiria. A autorização para o processo coletivo no sistema da equity denominava-se bill of peace e, uma vez concedida, as lides individuais poderiam ser todas reunidas num único processo. Com o tempo, o sistema avançou ainda mais e a autorização passou a representar a possibilidade de o provimento englobar os direitos de todos os envolvidos no litígio, ainda que não estivessem presentes em juízo ${ }^{156}$.

Os Estados Unidos da América, naturalmente, herdaram o duplo sistema inglês (common law e equity law), mas passaram a ter regramento autônomo a partir de 1842, com o advento da "Federal Equity Rule" $48^{157}$, posteriormente reformada pela "Federal Equity Rule" 38, de 1912, ambas extremamente sucintas: a primeira permitia a representação dos ausentes, mas não a extensão da coisa julgada que lhes prejudicasse; a

${ }^{154}$ V. René David, Os grandes sistemas do direito contemporâneo. São Paulo: Martins Fontes, 2002, p. 388. Vicente Rao menciona um terceiro "corpo" em que se dividiria o direito inglês, ao lado do direito comum (common law) e do direito-equidade (equity law): o direito estatutário (statute law), ou seja, o direito escrito ( $O$ direito e a vida dos direitos - vol. 1, tomo I. $2^{\text {a }}$ ed. São Paulo: Editora Resenha Universitária, 1976, p. 91). Guido Fernando da Silva Soares também menciona o statute law, que constitui o direito criado pelo legislador, mais presente nos EUA do que na Inglaterra, contrastado, num determinado sentido, ao common law, o direito criado pelo juiz (Common Law - Introdução ao direito dos EUA. $2^{\text {a }}$ ed. São Paulo: Editora Revista dos Tribunais, 2000, p. 37-47).

155 V. Antonio Gidi, A class action como instrumento de tutela coletiva dos direitos. São Paulo: Editora Revista dos Tribunais, 2007, p. 41.

156 Antonio Gidi sustenta ser incorreto atribuir às bill of peace o papel de únicas raízes da moderna class action, lembrando a existência de ações de grupo na Inglaterra medieval do século XII (A class action como instrumento de tutela coletiva dos direitos. São Paulo: Editora Revista dos Tribunais, 2007, p. 42)

157 A "Federal Equity Rule" 48 foi fortemente inspirada nos trabalhos de Joseph Story, juiz da Suprema Corte Americana de 1811 a 1845, que estudou profundamente as ações coletivas no sistema da equity com os olhos postos na questão do acesso à justiça, tendo publicado dois livros sobre o assunto, conforme Márcio Flávio Mafra Leal (Ações Coletivas: história, teoria e prática. Porto Alegre: Sergio Antonio Fabris Editor, 1998, p. 149). 
segunda suprimiu a limitação da coisa julgada, embora ela já estivesse sendo afastada pela jurisprudência quando houvesse "adequada representação das partes"158. Em 1938, porém, houve nova modificação, desta vez de caráter bem mais profundo.

Nesse ano foram promulgadas as Federal Rules of Civil Procedure, que visavam disciplinar o processo civil federal, uma vez que, nos Estados Unidos da América, a legislação estadual é da competência legislativa de cada Estado-membro ${ }^{159}$. Além disso, o objetivo foi unificar os sistemas da common law e da equity, de maneira que haveria a partir de então um único processo civil federal. Essa modificação teve uma enorme repercussão nas ações coletivas, em especial na tutela de interesses individuais homogêneos.

É que, além de preverem instrumentos processuais diferentes, os sistemas da common law e da equity reconheciam direitos materiais diferentes: pelas regras da common law, em caso de inexecução contratual, a tutela possível era a indenização por perdas e danos; pela equity, a tutela oferecida era a execução forçada (específica). Como a ação coletiva só era possível na equity, as únicas tutelas coletivas ao alcance dos interessados eram a declaratória ou a injuncional (mandamental ou condenatória de fazer ou não fazer $)^{160}$. Ocorre que a possibilidade de tutela indenizatória, por ser a mais comumente pretendida, constitui exigência para o desenvolvimento da tutela coletiva de interesses individuais homogêneos e esta só se tornou possível quando a ação coletiva passou a ser admissível no sistema da common law.

A Rule 23 foi a norma que disciplinou a ação coletiva, então denominada class action. As Federal Rules of Civil Procedure não são leis (statutes), no sentido que o Direito norte-americano empresta à palavra. Elas são produto de delegação do Congresso Nacional, por meio de uma lei, no caso, o Rules Enabling Act, de 1934, dirigida à Suprema

\footnotetext{
${ }^{158}$ V. Aloísio Gonçalves de Castro Mendes, Ações coletivas: no direito comparado e nacional. São Paulo: Editora Revista dos Tribunais, 2002, p. 67.

${ }^{159}$ No entanto, os estados-membros tendem a legislar no plano estadual seguindo as diretrizes da legislação federal, pelo menos no tocante à ação coletiva (v. Aloísio Gonçalves de Castro Mendes, Ações coletivas: no direito comparado e nacional. São Paulo: Editora Revista dos Tribunais, 2002, p. 73).

${ }^{160}$ Carlos Alberto de Salles explica que não havia uma separação absoluta entre os sistemas da common law, com a tutela reparatória, e o da equity, com a tutela injuncional, havendo casos em que um sistema admitia a tutela típica do outro, sendo mais relevante entender a diferença entre cada tipo de tutela do quem entre cada tipo de jurisdição, mesmo porque, os dois sistema foram fundido, como visto acima (Execução judicial em matéria ambiental. São Paulo: Editora Revista dos Tribunais, 1999).
} 
Corte para que esta fixasse normas processuais, sem a pretensão de constituir um código e sem poder modificar direitos materiais ${ }^{161}$.

Porém, o regramento continha obscuridades e omissões que causaram muitas dúvidas e problemas, especialmente porque estipulava categorias de ações muito difíceis de distinguir, com tratamentos diversos, algumas sem vinculação dos ausentes à coisa julgada, e não exigia a aferição da predominância das questões coletivas sobre as individuais nem a superioridade do processo coletivo sobre o individual. Assim, em 1966, a Rule 23 foi reformulada pela Suprema Corte, com o objetivo de estender os efeitos da coisa julgada a todos os membros da classe, fosse ela prejudicial ou benéfica, condicionada à representação adequada e leal ${ }^{162}$.

Antonio Gidi comenta que "o objetivo principal do legislador reformista de 1966 foi criar um instrumento processual efetivo que promovesse a aplicação em massa das políticas públicas contra a discriminação racial (civil rights). Portanto, o principal enfoque dos trabalhos foi a ação coletiva do tipo (b) (2). A inovação mais controvertida, porém, ficou a cargo das class actions do tipo (b) (3)",163. A principal alteração que atingiu as class action previstas na regra (b) (3) foi, naturalmente, a clara previsão da extensão da coisa julgada a todos os membros do grupo, estivessem ou não presentes, fosse em seu benefício ou em seu prejuízo. A regra (b) (3) da Rule 23 na nova versão deu novo tratamento a um tipo de ação coletiva que era conhecida por spurious class action (ação coletiva espúria ou falsa), justamente porque não era uma ação coletiva verdadeira, porquanto só produzia efeitos sobre as partes presentes em juízo. Esse tipo de ação é cabível quando os interesses são divisíveis, mas possuem uma questão de direito ou de fato comuns aos membros do grupo. Por essa razão, é considerada, pela doutrina, a origem da categoria dos interesses individuais homogêneos prevista na legislação brasileira ${ }^{164}$.

\footnotetext{
${ }^{161}$ V. Antonio Gidi, A class action como instrumento de tutela coletiva dos direitos. São Paulo: Editora Revista dos Tribunais, 2007, p. 46.

${ }^{162}$ V. Aloísio Gonçalves de Castro Mendes, Ações coletivas: no direito comparado e nacional. São Paulo: Editora Revista dos Tribunais, 2002, p. 72.

${ }^{163}$ A class action como instrumento de tutela coletiva dos direitos. São Paulo: Editora Revista dos Tribunais, 2007, p. 57-58.

${ }^{164}$ V. Ada Pelegrini Grinover (Da class action for damages à ação de classe brasileira: os requisitos de admissibilidade. In: Revista Forense n. 352, Rio de Janeiro, out./nov./dez. 2000, p. 4); Antonio Gidi (Coisa julgada e litispendência em ações coletivas. São Paulo: Saraiva, 1995, p. 138); Pedro Lenza (Teoria geral da ação civil pública. São Paulo: Editora Revista dos Tribunais, 2003, p. 232).
} 
Na sistemática norte-americana, a ação pode ser coletiva no polo ativo, no polo passivo ou em ambos. Quando proposta, a primeira decisão relevante, a ser tomada tão logo quanto possível, é a autorização para que ela possa tramitar como ação coletiva, a definição da espécie de class action em que se enquadrará e a delimitação da classe (e subclasses, eventualmente) que estará em juízo e ficará subordinada aos efeitos da coisa julgada $^{165}$; essa decisão, de enorme relevância prática ${ }^{166}$, é chamada certificação (certification). Nos Estados Unidos da América, explica Marcio Flavio Mafra Leal, "se a ação não for admitida como coletiva, ela terá prosseguimento normal sob a forma de ação

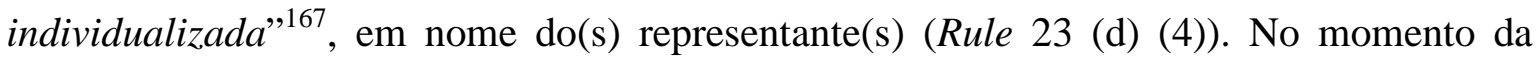
certificação, o juiz possui grande dose de discricionariedade, no sentido mesmo da análise da conveniência e oportunidade, incluindo até mesmo aspectos não dispostos na Rule 23, desde que pertinentes, e dificilmente é modificada pelos tribunais; em consequência, "ainda que o juiz considere que todos os requisitos exigidos pela Rule 23 estejam presentes, o juiz poderá, em tese, negar a certificação"168.

Ao contrário do que acontece no Brasil, a regulamentação da ação coletiva nos Estados Unidos da América não classifica tais ações conforme o tipo de interesse, ou seja, se difusos, coletivos em sentido estrito e individuais homogêneos, mas de acordo com certas características da tutela buscada ou com as consequências indesejáveis de eventual tutela individual naquele caso. São três categorias, as duas primeiras admitindo, cada uma, duas modalidades diversas, totalizando cinco tipos: “incompatible standarts class action" (Rule 23 (b) (1) (A)), "limited fund class action"

\footnotetext{
${ }^{165}$ Essa decisão pode ser condicionada e é retratável em qualquer momento antes da sentença (v. Luís Paulo da Silva Araújo, Ações coletivas: a tutela jurisdicional dos direitos individuais homogêneos. Rio de Janeiro: Forense, 2000, p. 27).

${ }^{166}$ A relevância decorre da alteração da situação das partes: antes, o grupo pode não ter qualquer poder de barganha, já que ninguém sabe se o autor coletivo poderá representar uma grande coletividade; depois, a causa de pequeno valor correspondente à pretensão do representante pode transformar-se numa causa de milhões, conforme o tamanho da classe que for certificada (v. Antonio Gidi, A class action como instrumento de tutela coletiva dos direitos. São Paulo: Editora Revista dos Tribunais, 2007, p. 198-200). Muitas vezes o réu, logo depois da certificação, passa a ver com bons olhos uma negociação visando um acordo que encerre o processo e vincule todos os membros da classe. Segundo Ada Pellegrini Grinover, $90 \%$ das ações certificadas como "class action for damages" terminam com um acordo (Da class action for damages à ação de classe brasileira: os requisitos de admissibilidade. In: Revista Forense n. 352, Rio de Janeiro, out./nov./dez. 2000, p. 7).

${ }^{167}$ Ações Coletivas: história, teoria e prática. Porto Alegre: Sergio Antonio Fabris Editor, 1998, p. 155 (nota 323).

${ }^{168}$ Antonio Gidi, A class action como instrumento de tutela coletiva dos direitos. São Paulo: Editora Revista dos Tribunais, 2007, p. 197-198.
} 
(Rule 23 (b) (1) (B)), "injunctive class action", "declaratory class action” (Rule 23 (b) (2)) e "class action for damages" (Rule 23 (b) (3)).

Os quatro primeiros tipos de class action, previstos nas duas primeiras categorias, ou seja, Rule 23 (b) (1) e (b) (2), não se prestam a pretensões indenizatórias propriamente e possuem o mesmo procedimento. Não existe uma correspondência perfeita com o modelo brasileiro, mas é nessas categorias que se enquadra a tutela de interesses difusos e a de coletivos em sentido estrito. Na experiência norte-americana, mais de 50\% das class actions se referem a interesses coletivos stricto sensu relacionados com a defesa dos direitos fundamentais do cidadão, incluindo presidiários ${ }^{169}$.

A “incompatible standarts class action" é aquela necessária para evitar pronunciamentos judiciais em ações individuais que possam determinar comportamentos diferentes e incompatíveis para a parte contrária à classe, como a ação proposta para que uma companhia telefônica adote determinada conduta em face de seus clientes. A "limited fund class action" consiste na ação coletiva para os casos em que o atendimento de pretensão individual de membro do grupo poderia prejudicar a pretensão futura de outro membro, como ocorre nas hipóteses em que o réu está falido ou poderá falir. Não havendo recursos disponíveis para indenizar todos os membros da classe, é indispensável que todos eles sejam reunidos para que tais recursos, então considerados como pertencentes a um "fundo", possam ser rateados de maneira a que nenhum dos membros tenha prejuízo maior do que o dos demais. Há quem a considere uma espécie de "ação de falência coletiva", que apresenta a vantagem de possibilitar um acordo da empresa-ré com a classe para evitar a quebra $^{170}$.

A "injunctive class action" e a "declaratory class action" são ações coletivas apropriadas para as situações nas quais o réu agiu ou deixou de agir contra seu dever legal em face do grupo todo, desafiando uma sentença mandamental ou declaratória, conforme o caso. Ambas as tutelas estão previstas na Rule 23 (b) (2) e, também nesse caso, a eventualidade de ações individuais poderia conduzir a determinações de condutas incompatíveis do réu, de modo que essas espécies podem ser consideradas espécies

\footnotetext{
${ }^{169}$ V. José Rogério Cruz e Tucci, “Class action” e mandado de segurança coletivo. São Paulo: Saraiva, 1990, p. 28.

${ }^{170}$ V. Antonio Gidi, A class action como instrumento de tutela coletiva dos direitos. São Paulo: Editora Revista dos Tribunais, 2007, p. 151.
} 
qualificadas das class action da Rule 23 (b) (1) ${ }^{171}$. Tanto isso é verdade que em nenhuma delas existe a possibilidade de o membro da classe ser excluído da ação e dos efeitos da coisa julgada (right to opt out). As ações da Rule 23 (b) (2) têm larga aplicação no terreno da repressão à discriminação e segregação racial, bem como à violação a outros direitos civis, como a liberdade religiosa ou sexual, mas também pode servir para a tutela de direitos do consumidor, como a repressão ao abuso de poder econômico ${ }^{172}$.

A “class action for damages" presta-se a pretensões indenizatórias por danos individualmente sofridos com base na responsabilidade civil ${ }^{173}$. Nesse tipo de ação, uma vez proposta, qualquer membro da classe tem o direito de requerer sua exclusão da ação, para não ficar vinculado aos efeitos da coisa julgada que vier a ser formada ${ }^{174}$. Para isso, é indispensável que o autor coletivo promova uma notificação a todos os membros que puderem ser identificados com "reasonable effort" (nos termos da Rule 23 (c) (2) (B), isto é, "razoável esforço"). A interpretação dessa regra tem surtido muitas controvérsias, em vista da rigidez com que tem sido realizada pelos tribunais, com vistas a evitar, a todo custo, a possibilidade de prejuízos a interesses individuais por falta de informação sobre a ação.

Em 1966, um investidor de Nova Iorque, Morton Eisen, propôs uma class action visando a reparação de danos que duas corretoras de valores teriam causado aos pequenos investidores, como ele, no período entre 1962 e 1966, por violação ao Sherman $A c t^{175}$, conspirando para monopolizar o mercado e cobrar taxas excessivas ${ }^{176}$. A Corte Distrital de Nova Iorque estimou que a classe compreenderia 6.000 .000 de pessoas, das quais 2.250 .000 poderiam ser identificadas a partir de um "razoável esforço".

\footnotetext{
${ }^{171}$ Idem, p. 154.

${ }^{172}$ V. Aloísio Gonçalves de Castro Mendes, Ações coletivas: no direito comparado e nacional. São Paulo: Editora Revista dos Tribunais, 2002, p. 89.

${ }^{173}$ V. Marcio Flávio Mafra Leal, Ações Coletivas: história, teoria e prática. Porto Alegre: Sergio Antonio Fabris Editor, 1998, p. 159.

${ }^{174}$ Esse direito é chamado de opt out e está previsto na Rule 23 (c) (2) (B).

${ }^{175}$ Lei antitruste norte-americana, de 1890, de autoria de John Sherman, senador republicano por Ohio (v. Thomas Di Lorenzo, Cato Handbook for Congress - 105th Congress. Disponível em www.cato.org/pubs/handbook/hb105-39.html, acesso em 18/09/2008).

176 As corretoras, "Carlisle\&Jacquelin" e "Decopper\&Doremus", controlavam 90\% do mercado de corretagem de pequenos lotes de ações (abaixo de 100), chamados "odd-lot share", negociadas na Bolsa de Valores de Nova Iorque (v. Antonio Gidi, A class action como instrumento de tutela coletiva dos direitos. São Paulo: Editora Revista dos Tribunais, 2007, p. 220).
} 
Ocorre que os custos da notificação postal de 2.250.000 pessoas seriam de US\$ 225.000,00, sendo que Eisen tinha um prejuízo individual a ser reparado de cerca de US\$ 70,00. Tendo em conta que isso impossibilitaria a ação, cuja indenização total ficava entre 60 e 120 milhões de dólares, com honorários advocatícios estimados em 5 milhões de dólares, a Corte Distrital reduziu a necessidade de notificação pessoal, permitindo que fosse feita pessoalmente apenas aos mais prejudicados e a alguns outros escolhidos por amostragem, sendo que os demais seriam notificados por meio de anúncios de jornal. A corte inverteu ainda o ônus financeiro, ao determinar que os réus adiantassem $90 \%$ dessas despesas.

Em 1975, porém, a Suprema Corte apreciou o caso e decidiu reafirmar a obrigatoriedade da notificação pessoal de todos os membros identificáveis, apegando-se a uma interpretação literal da norma, e manter o ônus financeiro sobre o autor, sob o fundamento da falta de amparo legal para a inversão. O resultado foi a inviabilização da ação: Eisen deixou de promover a notificação e a ação foi extinta sem julgamento pelo mérito $^{177}$.

Há casos, porém, em que as cortes, considerando que a identificação de todos os interessados exigiria mais do que "razoável esforço", admitem a notificação mediante publicação em órgãos de imprensa ${ }^{178}$.

A hipótese da "class action for damages", conforme a Rule 23 (b) (3), é aquela na qual predominam as questões de direito ou de fato comuns sobre qualquer questão individual dos membros do grupo ("predominance") e na qual o julgamento da controvérsia por meio de ação coletiva é superior a outros métodos disponíveis ("superiority"). Essa predominância "não significa que as questões comuns devam predominar em toda a controvérsia coletiva e que não possa haver alguns aspectos em que as questões individuais predominem sobre as questões comuns. O que a lei e o bom senso

177 V. Luis Paulo da Silva Araújo (Ações coletivas: a tutela jurisdicional dos direitos individuais homogêneos. Rio de Janeiro: Forense, 2000, p. 27); Marcio Flavio Mafra Leal (Ações Coletivas: história, teoria e prática. Porto Alegre: Sergio Antonio Fabris Editor, 1998, p. 161).

${ }^{178}$ José Rogério Cruz e Tucci menciona o precedente "Booth v. General Dynamics Corp.", em que a decisão sobre a notificação dos ausentes foi nesse sentido ("Class action” e mandado de segurança coletivo. São Paulo: Saraiva, 1990, p. 25). 
exigem é que somente sejam certificadas ações coletivas em que a diversidade das situações individuais não comprometa o tratamento uniforme da questão comum"179.

Quanto à superioridade do julgamento mediante ação coletiva, a Rule 23 (b) (3) estipula quatro critérios que devem ser considerados pelo juiz, entre outros, para aferir o atendimento a essa exigência: (A) o interesse de membros da classe em controlar individualmente a propositura ou defesa de ações separadas; (B) a extensão e natureza de qualquer litígio concernente à controvérsia já começado por membros da classe ou em face deles; (C) a conveniência ou a inconveniência da concentração de litígios sobre aquelas pretensões num específico juízo; (D) as dificuldades que provavelmente serão encontradas na administração da ação coletiva ${ }^{180}$.

O interesse na propositura de ações individuais deve ser avaliado com base na existência de justo motivo para que grande parte do grupo tenha interesse de litigar coletivamente, como a presença de questões importantes relativas à causa de natureza pessoal dos membros do grupo ou a conveniência de adaptação das estratégias de atuação em juízo às necessidades individuais, considerando-se também a proporção de membros do grupo nessa situação e a expressividade do valor individual das indenizações pretendidas por cada um deles. Se houver justo interesse de parcela pequena dos membros do grupo, eles sempre poderão utilizar-se do direito de opt out para ir litigar individualmente, sem com isso inviabilizar a ação coletiva ${ }^{181}$.

A análise da extensão e natureza de litígios individuais já começadas é indispensável porque a certificação da ação coletiva terá o efeito de substituir essas ações individuais pela ação coletiva. Assim, o juiz deverá verificar se essas ações são muitas (podendo pesar a favor do autor coletivo, por significar muito serviço judiciário já perdido, ou a favor do réu, por significar muito serviço judiciário a ser perdido, se as ações individuais prosseguirem, além de sobrecarregar o réu injustamente), se as ações já estão na fase final, se são muito variadas, se houve tempo suficiente para os membros proporem ações individuais etc.

\footnotetext{
${ }^{179}$ Antonio Gidi, A class action como instrumento de tutela coletiva dos direitos. São Paulo: Editora Revista dos Tribunais, 2007, p. 166.

${ }^{180}$ Tradução do autor.

${ }^{181}$ V. Antonio Gidi, A class action como instrumento de tutela coletiva dos direitos. São Paulo: Editora Revista dos Tribunais, 2007, p. 178.
} 
$\mathrm{O}$ interesse de concentrar os litígios em determinado juízo, o terceiro critério normativo, envolve a avaliação da efetividade, da economia processual e da eficácia em prevenir a formação de sentenças contraditórias, explica Antonio Gidi, com base em doutrina e na constatação de que, no sistema da common law, o juiz pode declinar da sua competência alegando a inconveniência do foro, ao contrário do que ocorre no sistema da civil law, no qual as regras de distribuição de competência são cogentes ${ }^{182}$.

O último critério é o da dificuldade na administração da ação coletiva (manegeability). Segundo Antonio Gidi, esse requisito "tem sido o fator mais acirradamente litigado entre as partes e aquele mais freqüentemente invocado pelos tribunais para considerar a tutela coletiva uma alternativa inferior e recusar a sua certificação". As dificuldades aceitáveis para recusar a certificação, segundo o autor, não se referem aos problemas da administração da justiça (tempo excessivo a ser despendido e atraso que acarretará nos outros processos), nem à complexidade da ação proposta considerada em si mesma (dificuldades que aparecerão se o litígio for resolvido com o uso de qualquer alternativa disponível), mas à comparação desses problemas com as vantagens da tutela coletiva. Alguns dos aspectos que os tribunais americanos têm considerado comprometedores para o gerenciamento da ação coletiva são a complexidade e a numerosidade das questões fáticas e jurídicas individuais; o tamanho e a dispersão geográfica do grupo; problemas de identificação e notificação dos membros do grupo; dificuldades de instrução do júri (direito constitucional geralmente assegurado no caso de "class action for damages"); número excessivo de membros excluindo-se do grupo; a insignificância das pretensões individuais; dificuldades na distribuição do fundo; e a propositura de reconvenções obrigatórias ${ }^{183}$.

Não obstante a necessidade de definir qual é a espécie de ação coletiva, como regra ${ }^{184}$, todas elas devem atender aos quatro requisitos da Rule 23 (a), de forma

\footnotetext{
${ }^{182}$ Idem, p. 181-182.

${ }^{183}$ V. Antonio Gidi, A class action como instrumento de tutela coletiva dos direitos. São Paulo: Editora Revista dos Tribunais, 2007, p. 182-185.

184 Antonio Gidi sustenta que, por estarem dispostas numa ordem decrescente de especificidade, existe sobreposição entre as categorias, de modo que, se alguma situação atende a subdivisão (b) (1) ou (b) (2), também atende a subdivisão (b) (3). Por isso, há casos em que a ação é certificada como class action com base em duas ou até nas três categorias, assim como já houve casos de certificação numa categoria ou em outra, sem especificar qual (Idem, p. 191).
} 
cumulada, que são: a impraticabilidade do litisconsórcio (ou numerosidade), a existência de questões comuns; a tipicidade e a representação adequada ${ }^{185}$.

O litisconsórcio será impraticável, mesmo que seja possível, se for extremamente difícil ou inconveniente, restringindo o acesso à justiça, ou seja, sem a ação coletiva, provavelmente as ações individuais não serão propostas. É o caso da classe muito numerosa, de membros muito dispersos, de titulares de interesses individuais diminutos, de membros hipossuficientes etc.

O requisito seguinte, de acordo com a Rule 23, da "commonality", é configurado pela existência de pelo menos uma questão comum, de fato ou de direito, a ligar todos os membros do grupo. Nem todas as questões a serem apreciadas precisam ser comuns a todos os membros do grupo, mas é preciso que as questões comuns "incidam sobre ponto relevante para a causa e deve ser, inclusive, conjugada e avaliada em conformidade com a exigência, contida na Rule 23 (b) (3), de predominância das questões comuns e de superioridade da defesa coletiva sobre a individual" ${ }^{, 86}$.

A necessidade da existência de questões comuns, talvez o requisito que mais caracteriza a class action, é decorrência da própria natureza dos interesses a serem tutelados e, segundo a doutrina, o único requisito que a lei não poderia dispensar em nenhuma hipótese, por ser da essência da tutela coletiva: "trata-se de requisito indispensável, sendo o alicerce do cabimento de qualquer ação coletiva e da própria existência de uma controvérsia de natureza coletiva e de um grupo"187.

O terceiro requisito, da tipicidade, significa que a pretensão do autor coletivo deve ser típica do grupo por ele representado, ou seja, os pedidos ou as defesas do representante devem ser iguais aos pedidos ou às defesas dos membros do grupo. Daí resulta que, por esse requisito, o representante tem de ser um dos membros do grupo $^{188}$. Se

\footnotetext{
185 Aloísio Gonçalves de Castro Mendes refere que a doutrina norte-americana considera haver um outro requisito, implícito: a existência de uma classe identificável (Ações coletivas: no direito comparado e nacional. São Paulo: Editora Revista dos Tribunais, 2002, p. 74).

${ }^{186}$ Idem, p. 76.

${ }^{187}$ Antonio Gidi, A class action como instrumento de tutela coletiva dos direitos. São Paulo: Editora Revista dos Tribunais, 2007, p. 79.

${ }^{188}$ Aloísio Gonçalves de Castro Mendes refere que alguns autores, como Robert H. Klonoff, consideram a condição de ser membro do grupo como outro requisito da class action, implícito, conquanto outros autores o identifiquem com o requisito da tipicidade, como Jack H. Friendenthal, Mary Kay Kane e Arthur R. Miller
} 
o processo perder o objeto em face do representante (por exemplo, se ele fizer um acordo com o réu), a ação coletiva não é extinta, mas o representante deve ser substituído, assim como acontece se ficar comprovado que o representante não é parte do grupo, por não ter identidade de pretensões com o grupo.

O último requisito, talvez o mais importante, é o da representação adequada. Com efeito, da representação adequada decorre não apenas a legitimidade do representante, mas também a possibilidade de que a coisa julgada da ação coletiva vincule os membros ausentes do grupo sem violar o devido processo legal. É preciso ter em mente que, na class action, o representante não possui qualquer autorização específica dos membros do grupo para defender os interesses deles em juízo. Natural que, nessa situação, o representante tenha de possuir, ao menos, aptidão para fazer a defesa dos interesses de todos os membros do grupo, em tese, de forma tão apropriada quanto se presume que os próprios membros fariam se eles próprios estivessem em juízo ${ }^{189}$. Antonio Gidi lembra precedente (Hansberry v. Lee) no qual ficou estabelecido que "a decisão de uma ação coletiva fará coisa julgada somente em relação aos membros do grupo ausentes do processo que foram adequadamente representados em juízo" ${ }^{\text {"190. }}$.

A adequação do representante, assim, resulta da "qualidade da defesa dos interesses da classe. Em relação às partes representativas, são considerados o comprometimento com a causa, a motivação e o vigor na condução do feito, o interesse em jogo, as disponibilidades de tempo e a capacidade financeira, o conhecimento do litígio,

(Ações coletivas: no direito comparado e nacional. São Paulo: Editora Revista dos Tribunais, 2002, p. 77). Antonio Gidi sustenta que a "membridade" não é um quinto requisito: "se houver tipicidade da lide do autor em face da dos demais membros do grupo é porque ele é um membro do grupo" (A class action como instrumento de tutela coletiva dos direitos. São Paulo: Editora Revista dos Tribunais, 2007, p. 90).

189 Cássio Scarpinella Bueno sustenta que a cláusula do "due processo of law”, também de estatura constitucional nos Estados Unidos da América (quinta e décima quarta emendas à Constituição americana), "seria, 'per se', um fator bastante limitativo para o cabimento das ações de classe", não fosse a "revisitação" do conceito de devido processo legal "a partir das novas exigências criadas para o direito processual diante da mutação do direito material". Para o autor, "na doutrina que estuda as class action, é comum a expressão de que, se todos estes membros ausentes foram devidamente representados, não há como questionar que tenham tido 'their own day in court"' (As class actions norte-americanas e as ações coletivas brasileiras: pontos para um reflexão conjunta. In: Revista de Processo n. 82, São Paulo, Editora Revista dos Tribunais, abr./jun. 1996, p. 100-102).

${ }^{190}$ A class action como instrumento de tutela coletiva dos direitos. São Paulo: Editora Revista dos Tribunais, 2007, p. 103. 
honestidade, qualidade de caráter, credibilidade e, com especial relevo, a ausência de conflito de interesse" ${ }^{\prime 191}$.

Como visto, o pressuposto da representação adequada visa também a evitar conflitos de interesses entre membros do grupo ou entre o representante e os demais membros do grupo, e até mesmo de colusão entre o representante e a parte contrária, de modo a prejudicar os interesses dos membros ausentes, hipóteses que representam sério perigo numa situação em que interesses de ausentes poderão ser seriamente prejudicados. Além disso, a adequação é aferida não apenas em função da atuação do próprio representante do grupo, mas também da atuação do representante deste em juízo, isto é, o advogado. A qualquer tempo o juiz pode, convencendo-se de que a representação não está sendo adequada, convidar outros membros do grupo a intervir ou, se não for possível, afastar os efeitos da coisa julgada sobre os membros não adequadamente representados ${ }^{192}$.

Quanto ao procedimento, no tocante à “class action for damages”, após a certificação, se não houver acordo, a decisão será tomada pelo júri, como regra, onde serão produzidas as provas. A decisão do júri pode ser confirmada ou rejeitada pelo juiz de primeira instância. Se confirmada, será proferida sentença de mérito, de caráter genérico, seguindo-se a liquidação dos danos, também julgada por sentençaa ${ }^{193}$.

Diferença importante do sistema norte-americano em relação ao brasileiro é que a ação coletiva não termina na sentença genérica. $\mathrm{O}$ mesmo processo prevê uma segunda fase na qual o juiz promove a apuração dos danos individuais ${ }^{194}$.

191 Aloísio Gonçalves de Castro Mendes (Ações coletivas: no direito comparado e nacional. São Paulo: Editora Revista dos Tribunais, 2002, p. 82).

${ }^{192}$ V. José Rogério Cruz e Tucci, “Class action” e mandado de segurança coletivo. São Paulo: Saraiva, 1990, p. 21. A doutrina menciona caso em que o representante, por ter-se sentido satisfeito com a sentença, deixou de apelar. Essa omissão foi considerada suficiente para concluir que, a partir da sentença, o representante deixou de defender "vigorosa e tenazmente os demais", razão pela qual se decidiu "ter inocorrido a eficácia subjetiva da coisa julgada para os outros, no sentido de que o resultado não obstaria que propusessem as suas ações individualmente" (José Manoel Arruda Alvim, Código do consumidor comentado. $2^{\mathrm{a}}$ ed. São Paulo: Editora Revista dos Tribunais, 1995, p. 353).

${ }^{193}$ V. Ada Pellegrini Grinover, Da class action for damages à ação de classe brasileira: os requisitos de admissibilidade. In: Revista Forense n. 352, Rio de Janeiro, out./nov./dez. 2000, p. 6.

194 Antonio Gidi explica que o juiz pode utilizar várias técnicas nessa segunda fase da "class action for damages": recorrer a auxiliares de justiça para decidir as questões individuais, apurar os danos por amostragem, apurar os danos globalmente em vez de individualmente etc. (A class action como instrumento de tutela coletiva dos direitos. São Paulo: Editora Revista dos Tribunais, 2007, p. 172). 
Verificadas as principais características da class action, impõe-se fazer uma comparação, ainda que restrita aos interesses individuais homogêneos, com a ação coletiva brasileira. Já foi visto que no Direito norte-americano a classificação das ações coletivas não é feita de acordo com a natureza dos interesses envolvidos, ainda que possamos dizer, com boa aproximação, que a "class action for damages" se equipara à ação coletiva de tutela de interesses individuais homogêneos. A equiparação só não é mais exata porque os interesses individuais homogêneos nem sempre consistem na reparação de danos, mediante condenação na obrigação de pagar, hipótese exclusiva da "class action for damages".

Quanto aos pressupostos, lembra Antonio Gidi que, não obstante haver alguma sobreposição entre a tipicidade, a existência de questões comuns e a representação adequada, no sentido de se confundirem em certos aspectos, trata-se de conceitos que devem ser analisados separadamente ${ }^{195}$, assim como acontece com a numerosidade.

O pressuposto da tipicidade não é exigência no Direito brasileiro, porque aqui o legislador optou por não atribuir legitimação para pessoas físicas, mas tão-somente para pessoas jurídicas ou para o MP. Assim, não se cogita terem essas pessoas o mesmo interesse coletivo que elas pretendem ver tutelado, uma vez que não são membros do grupo a que ele corresponde. No Direito norte-americano, no qual qualquer membro da classe pode, em tese, ser considerado parte legítima para propor uma class action, a tipicidade é um pressuposto necessário (ainda que não suficiente) para que haja adequação do representante, garantia de que será assegurado o devido processo legal aos membros ausentes.

Já o requisito da existência de questões comuns, essência da tutela coletiva, como visto, evidentemente está presente na legislação brasileira, pois só na sua presença se poderá falar na configuração de interesse coletivo, em sentido largo, a ser tutelado. No tocante à "class action for damages", o requisito é ainda mais exigente, porque não basta a existência de questões comuns, elas precisam predominar. Conforme visto no capítulo 3, a predominância das questões comuns também é requisito da tutela coletiva de interesses individuais homogêneos, no sentido de que, sem ela, inexiste utilidade na ação coletiva, porque a sentença genérica será inviável, porque a definição dos

${ }^{195}$ Idem, p. 136-137. 
elementos mínimos da obrigação que ela precisa declarar dependerá da discussão de um número indefinido de situações individuais.

Da mesma forma, o requisito da superioridade está presente no Direito brasileiro pela via do interesse de agir sob o ponto de vista da necessidade, uma vez que, na prática, a tutela coletiva pode tornar-se essencial para que os sujeitos obtenham o bem da vida subjacente a esses interesses. A eficácia da tutela coletiva nos casos em que é conveniente a sua utilização pode ser uma exigência da situação, de acordo com a espécie de violação e da dificuldade dos obstáculos colocados aos interessados para obterem a tutela jurisdicional.

A objeção a essa conclusão consiste na verificação das grandes diferenças entre o sistema americano, no qual diversas alternativas à ação coletiva são colocadas às partes, e o brasileiro, onde tais opções inexistem ${ }^{196}$. Ocorre que basta uma outra opção, no caso, das ações individuais, para seja possível fazer uma comparação e estabelecer uma relação de superioridade. É o que ocorre no Brasil ${ }^{197}$.

Como uma das faces do interesse processual, condição da ação, nos termos da legislação processual ${ }^{198}$, a utilidade do processo não só pode como deve ser aferida pelo juiz no momento do recebimento da petição inicial ou mesmo após ${ }^{199}$.

O requisito da representatividade adequada tem suscitado discussão na doutrina. Enquanto no Direito norte-americano se trata de pressuposto a ser detidamente aferido pelo juiz, no Direito brasileiro encontra-se contido na norma de atribuição de legitimidade para a propositura da ação civil pública, resultando na presunção de

\footnotetext{
${ }^{196}$ Antonio Gidi nega a aplicabilidade, no Brasil, tanto da predominância das questões comuns como da superioridade, lembrando a existência, nos EUA, das técnicas alternativas da consolidação (unificação total ou apenas da fase probatória de diversas ações individuais) e dos casos-teste com aplicação do collateral estoppel (extensão a casos semelhantes do julgamento de casos representativos da controvérsia especialmente escolhidos), entre outros (A class action como instrumento de tutela coletiva dos direitos. São Paulo: Editora Revista dos Tribunais, 2007, p. 172).

${ }^{197}$ No mesmo sentido, Ada Pellegrini Grinover (Da class action for damages à ação de classe brasileira: os requisitos de admissibilidade. In: Revista Forense n. 352, Rio de Janeiro, out./nov./dez. 2000, p. 10-12). É evidente que existem grandes diferenças: sendo um sistema muito mais complexo, a avaliação da superioridade nos Estados Unidos é muito mais difícil.

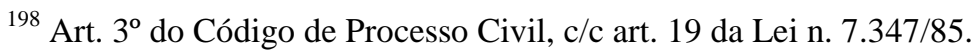

${ }^{199}$ Art. 267, parágrafo $3^{\circ}$, do Código de Processo Civil.
} 
adequação dos entes ali referidos ${ }^{200}$. Não há previsão legal expressa determinando a aferição, pelo juiz, da adequação da representação promovida por tais entes ${ }^{201}$. A discussão refere-se a saber se essa presunção é absoluta ou relativa e se o juiz pode examinar essa questão de ofício.

Alguns entendem que não há controle judicial sobre a representação adequada no Direito brasileiro, por ausência de previsão legal específica ${ }^{202}$. Outros sustentam que a necessidade de controle judicial fica afastada pela natureza dos efeitos da sentença secundum eventum litis $^{203}$, ou seja, os efeitos da sentença na tutela coletiva de interesses individuais homogêneos serão erga omnes apenas se ela for favorável aos autores e não impedirão as ações individuais dos ausentes.

Mas uma análise mais detida da questão resulta numa conclusão diversa. No regime do Código de Defesa do Consumidor, o prejuízo a que ficam sujeitos os interessados ausentes é manifesto.

Se a ação coletiva for julgada improcedente, nova ação coletiva ficará impedida, equiparando-se à situação da sentença de procedência, salvo quanto às ações individuais, que não ficam obstadas ${ }^{204}$. Mas a situação dos ausentes na ação coletiva em defesa de interesses individuais homogêneos é ainda mais prejudicial do que aquela reservada para a tutela de interesses difusos ou coletivos, uma vez que o julgamento de

\footnotetext{
${ }^{200}$ Art. $5^{\circ}$ da Lei n. 7.347/85 e art. 82 do Código de Defesa do Consumidor.

${ }^{201}$ A previsão expressa desse controle estava contida no projeto de lei que deu origem à Lei n. 7.347/85 (PL n. 3.084/84, art. $2^{\circ}$ e incisos), mas a redação final acabou alterada, informa Rodolfo de Camargo Mancuso (Ação civil pública. $5^{\mathrm{a}}$ ed. rev. atual. amp. São Paulo: Editora Revista dos Tribunais, 1997, p. 78).

${ }^{202}$ V. José Manoel Arruda Alvim et al. (Código do consumidor comentado. $2^{a}$ ed. São Paulo: Editora Revista dos Tribunais, 1995, p. 381-382); Antonio Herman Vasconcelos Benjamin (A Insurreição da Aldeia Global contra o Processo Civil Clássico: apontamentos sobre a opressão e a libertação judiciais do meio ambiente e do consumidor, p. 64. Biblioteca Digital do Superior Tribunal de Justiça, disponível em <http://bdjur.stj.gov.br/dspace/handle/2011/8688>, acesso em 30/10/2008); Luis Roberto Barroso (A proteção coletiva dos direitos no Brasil e alguns aspectos da class action norte-americana. In: Revista de Processo n. 130, São Paulo, Editora Revista dos Tribunais, dez. 2005, p. 152).

${ }^{203}$ Art. 103, inciso III e parágrafo $2^{\circ}$, do Código de Defesa do Consumidor.

204 Nesse sentido, Ada Pellegrini Grinover et al. (Código brasileiro de defesa do consumidor comentado pelos autores do anteprojeto. $5^{\mathrm{a}}$ ed. rev. atual. amp. Rio de Janeiro: Forense Universitária, 1998, p. 727); Vicente Greco Filho (In: OLIVEIRA, Juarez de (coord.), Comentários ao Código de Proteção ao Consumidor. São Paulo: Saraiva, 1991, p. 364); José Manoel Arruda Alvim Código do consumidor comentado. $2^{a}$ ed. São Paulo: Editora Revista dos Tribunais, 1995, p. 470); José Rogério Cruz e Tucci (Limites subjetivos da eficácia da sentença e da coisa julgada nas ações coletivas. In: Revista do Advogado da AASP, n. 89, dez. 2006, p. 78).
} 
improcedência por falta de prova não afasta a extensão a eles dos efeitos da sentença, pelo menos no plano coletivo.

Considerando os inúmeros obstáculos ao acesso à justiça que dificultam a defesa de interesses individuais homogêneos, o impedimento de nova ação coletiva já é prejuízo suficiente para que a representatividade seja concretamente verificada. Não se pode esquecer que o princípio do devido processo legal (art. $5^{\circ}$, inciso LIV, da Constituição Federal) exige o respeito às garantias da ampla defesa e do contraditório, evidentemente comprometidas por um representante que não possa, não queira ou, por qualquer motivo, não consiga produzir uma defesa eficiente dos interesses da classe representada.

Antonio Gidi, ao defender que "apesar de não estar expressamente previsto em lei, o juiz brasileiro não somente pode, como tem o dever de avaliar a adequada representação dos interesses do grupo em juízo",sustenta que "o representante inadequado, portanto, é um não-representante. Essa é uma questão extremamente delicada no caso das ações coletivas, em que o representante não foi eleito, selecionado, ou sequer aprovado pelos representados. O representante obtém essa posição por manifestação da sua própria vontade, ao propor a ação em benefício de uma coletividade. O mínimo que esse estranho tipo de 'representante' deve ser é adequado. Essa adequação deve ser submetida a um rigoroso controle judicial" ${ }^{205}$.

Não é que o juiz, no sistema brasileiro, possua os mesmos poderes do sistema norte-americano, onde há amplo espaço para verificação da representatividade adequada, mesmo porque inexistem critérios legais de legitimação presumida ou intervenção obrigatória do Ministério Público, como ocorre no Brasil. O que o juiz brasileiro deve fazer é, convencendo-se da inadequação do representante, considerar afastada a presunção da sua legitimidade, imposta pela legislação (art. 82 do Código de Defesa do Consumidor), que não pode ser interpretada como absoluta, sob pena da inefetividade da cláusula do devido processo legal ${ }^{206}$. Nesse caso, deve determinar a sua

205205 A class action como instrumento de tutela coletiva dos direitos. São Paulo: Editora Revista dos Tribunais, 2007, p. 134-133.

206 No mesmo sentido, Pedro Lenza (Teoria geral da ação civil pública. São Paulo: Editora Revista dos Tribunais, 2003, p. 293-198). Ada Pellegrini Grinover, inicialmente, entendeu em sentido contrário, sustentando que "o sistema brasileiro não escolheu o caminho do controle judicial da representatividade adequada, satisfazendo-se com o critério da existência legal e da pré-constituição das associações 
substituição ou, se inviável, extinguir o processo sem julgamento do mérito, com base no art. 267, inciso IV, do Código de Processo Civil.

\subsection{2 - A Lei da Ação Civil Pública e o Código de Defesa do Consumidor}

A tutela de interesses coletivos no Brasil, antes de 1985, resumia-se ao processo coletivo trabalhista ${ }^{207}$ e à ação popular $^{208}$. Foi com a Lei n. 7.347, de 24/07/85, que a tutela desses interesses tornou-se mais generalizada, pois ela instituiu a ação civil pública para a tutela de interesses difusos e coletivos relativos ao meio ambiente, ao consumidor e a bens e direitos de valor artístico, estético, histórico e paisagístico (art. $1^{\circ}$, na sua redação original) ${ }^{209}$. Posteriormente, com a previsão da tutela coletiva na Constituição Federal de 1988, as hipóteses de aplicação da ação civil pública já não podiam ser interpretadas restritivamente, como pretendeu o legislador ordinário, originalmente.

Até esse momento, porém, a tutela transindividual prevista no ordenamento jurídico nacional não contemplava expressamente os interesses individuais homogêneos ${ }^{210}$. Isso porque a Lei da Ação Civil Pública voltava-se à tutela de interesses

legitimadas às ações coletivas" (Código brasileiro de defesa do consumidor comentado pelos autores do anteprojeto. $5^{\mathrm{a}}$ ed. rev. atual. amp. Rio de Janeiro: Forense Universitária, 1998, p. 709-710); mais recentemente, porém, passou a defender que "o sistema brasileiro, embora não o afirme expressamente, não é avesso ao controle da representatividade adequada pelo juiz, em cada caso concreto" (Ações coletivas ibero-americanas: novas questões sobre a legitimidade e a coisa julgada. In: Revista Forense vol. 361, São Paulo, maio/jun. 2002, p. 5).

${ }^{207}$ V. Nelson Nery Júnior, Ação civil pública trabalhista e os direitos individuais homogêneos. In: DIDIER JÚNIOR, Fredie. Execução Civil - Estudos em homenagem ao professor Paulo Furtado. Rio de Janeiro: Lúmen Júris, 2006, p. 383-402.

${ }^{208}$ V. José Carlos Barbosa Moreira, A ação popular do direito brasileiro como instrumento de tutela coletiva dos chamados "interesses difusos". In: Revista de Processo n. 28, São Paulo, Editora Revista dos Tribunais, out./dez. 1982, p. 7-19.

${ }^{209}$ Gregório Assagra de Almeida chega a dividir a evolução do denominado "direito processual coletivo comum brasileiro" em duas fases, isto é, antes e depois da Lei n. 7.347/85 (Direito processual coletivo brasileiro. São Paulo: Saraiva, 2003, p. 263-265).

${ }^{210}$ Não obstante, a Lei n. $7.913 / 89$ previu o cabimento de ação coletiva para tutela dos interesses individuais homogêneos de investidores no mercado de valores mobiliários, atribuindo legitimidade exclusiva ao Ministério Público, a par da ação civil pública prevista na Lei n. 7.347/85, que só podia amparar interesses difusos ou coletivos em sentido estrito, naquele momento (v. Rodolfo de Camargo Mancuso, Ação civil pública para tutela dos interesses dos titulares de valores mobiliários e investidores do mercado. In: Revista dos Tribunais, vol. 650, São Paulo, Editora Revista dos Tribunais, dez. 1989, p. 31-39). Teori Albino Zavascki menciona também outra previsão de ação civil pública para tutela de interesses individuais homogêneos, mais antiga e também sem essa denominação, na Lei n. 6.024/74, destinada a apurar a responsabilidade de ex-administradores de instituições financeiras em regime de intervenção ou liquidação 
essencialmente coletivos, uma vez que não previa instrumento de reparação a prejuízos individualmente sofridos. Prova disso é a previsão, contida no seu art. 13, de que eventual produto da condenação será revertido a um fundo, não aos interessados cujos interesses individuais tenham sido violados por uma causa comum ${ }^{211}$.

A introdução da tutela coletiva de interesses individuais homogêneos ocorreu com a entrada em vigor do Código de Proteção e Defesa do Consumidor (CDC), Lei n. 8.078, de 11/09/1990. Essa lei não apenas sistematizou os interesses coletivos em sentido $\operatorname{amplo}^{212}$, incluindo a definição e previsão expressa, pela primeira vez no ordenamento jurídico nacional, dos interesses individuais homogêneos, como também ampliou de maneira ilimitada o rol de interesses difusos e coletivos passíveis de defesa por meio da ação civil pública e constitui, com a Lei n. 7.347/85, conforme Gregório Assagra de Almeida, "um verdadeiro microssistema de tutela dos direitos e interesses de massa"213. Isso porque existe uma inteligente integração entre os dois diplomas legais imposta pelo legislador no CDC, ao dispor no art. 90 que "aplicam-se às ações previstas neste título as normas do Código de Processo Civil e da Lei $n^{\circ}$ 7.347, de 24 de julho de 1985, inclusive no que respeita ao inquérito civil, naquilo que não contrariar suas disposições", bem como no art. 117, acrescentando o art. 21 na Lei n. 7.347/85, para dispor que "aplicam-se à defesa dos direitos e interesses difusos, coletivos e individuais, no que for cabível, os dispositivos do Título III da lei que instituiu o Código de Defesa do Consumidor,214.

extrajudicial (Ministério Público, ação civil pública e defesa de direitos individuais homogêneos. In: Revista Forense, vol. 92, n. 333, Rio de Janeiro, jan./fev./mar. 1996, p. 130).

211 Nesse sentido, Rodolfo de Camargo Mancuso (In: OLIVEIRA, Juarez de (coord.), Comentários ao Código de Proteção ao Consumidor. São Paulo: Saraiva, 1991, p. 288).

${ }^{212}$ Art. 81.

${ }^{213}$ Direito processual coletivo brasileiro. São Paulo: Saraiva, 2003, p. 266.

${ }^{214}$ Isso não aconteceu sem que houvesse uma tentativa do Poder Executivo de impedir a extensão dos dispositivos processuais do CDC à tutela de outros interesses transindividuais. O art. 89, contido no Título III do Código, "Da Defesa do Consumidor em Juízo", dispunha que "as normas deste Título aplicam-se, no que for cabível, a outros direitos ou interesses difusos, coletivos e individuais homogêneos, tratados coletivamente", mas foi vetado sob a justificativa de que essa extensão excederia os objetivos do código (como se o legislador não pudesse inserir outras matérias no mesmo diploma legal, exatamente como o Poder Executivo tantas vezes faz em seus projetos de lei), que as outras relações jurídicas reclamariam regulação própria e adequada (como se essa regulação não pudesse ser, para começar, a própria extensão) e que deveria "o legislador limitar-se a elaborar Código de Defesa do Consumidor" (sic), conforme a Constituição (como se o legislador estivesse impedido de legislar sobre outros assuntos). Felizmente, a "ponte" entre as duas leis construída pelo Código de Defesa do Consumidor era tão "sólida" que resistiu, por meio dos mencionados arts. 90 e 117, a essa tentativa de "implosão" (v. Mensagem n. 664, de 11/09/90, da Subchefia para Assuntos Jurídicos da Casa da Presidência da República, 
Da interpretação sistemática desses dispositivos, é possível extrair o funcionamento do sistema de tutela coletiva instituído por esses dois diplomas legais para fins de tutela de interesses individuais homogêneos. Em primeiro lugar, as ações coletivas propostas em defesa de interesses individuais homogêneos podem objetivar qualquer tipo de tutela adequada e efetiva, nos termos do art. 83, aplicável a quaisquer interesses individuais homogêneos por força do art. 21 da Lei n. 7.347/85, ou seja, qualquer pedido de natureza cautelar, cominatória, condenatória, mandamental ou executória (esta última também a título individual, conforme art. 97 do CDC) $)^{215}$.

Em segundo lugar, tais ações seguem os ritos do Código de Processo Civil (comum ordinário ou comum sumário), salvo disposição específica em sentido contrário no CDC, seja qual for a matéria, consumerista ou não. Isso porque as disposições processuais contidas no Título III do CDC se aplicam à tutela de quaisquer interesses individuais homogêneos (art. 21 da Lei n. 7.347/85), prevalecendo sobre as normas gerais do Código de Processo Civil, se conflitantes.

Em terceiro lugar, muito mais importante do que definir se deve ser denominada ação civil pública ou ação coletiva aquela que tutela interesses individuais homogêneos ${ }^{216}$, é verificar, nessa hipótese, quais dispositivos do CDC e da Lei da Ação Civil Pública são aplicáveis e quais não são ${ }^{217}$. Relevante é esclarecer se a coletividade

www.planalto.gov.br/ccivil_03/Leis/Mensagem_Veto/anterior_98/vep664-L8078-90.htm, acesso em 14/10/2008).

${ }^{215}$ V. Rodolfo de Camargo Mancuso, Manual do consumidor em juízo. $3^{\mathrm{a}}$ ed. rev. atual. amp. São Paulo: Saraiva, 2001, p. 50.

216 Como fazem, desnecessariamente, João Batista de Almeida (Aspectos controvertidos da ação civil pública. São Paulo: Editora Revista dos Tribunais, 2001, p. 36) e José Manoel Arruda Alvim (Código do consumidor comentado. $2^{a}$ ed. São Paulo: Editora Revista dos Tribunais, 1995, p. 385), entre outros. Em matéria de denominação, é mais consistente a posição de José Marcelo Menezes Vigliar (Ação civil pública ou ação coletiva? In: MILARÉ, Edis (coord.). Ação civil pública, lei 7.347/1985 - 15 anos. $2^{\mathrm{a}}$ ed. São Paulo: Editora Revista dos Tribunais, 2002, p. 441-457), defendendo que ambas as denominações são equivocadas, por não corresponderem a um critério científico de classificação das ações com base na espécie de tutela buscada, sendo que ação coletiva pelo menos indica, com acerto, o tipo de tutela buscada, enquanto ação civil pública quase nada esclarece. Ricardo de Barros Leonel também reputa equivocadas ambas as denominações, sustentando o descabimento da adjetivação das demandas (Manual do processo coletivo. São Paulo: Editora Revista dos Tribunais, 2002, p. 120).

${ }^{217}$ Rodolfo de Camargo Mancuso sustenta que o qualificativo "pública" serve pelo menos para designar uma ação de "largo espectro social de atuação", além de a locução "ação civil pública" estar "já consagrada" (Ação civil pública. $5^{\mathrm{a}}$ ed. rev. atual. amp. São Paulo: Editora Revista dos Tribunais, 1997, p. 13-20). Antonio Herman Vasconcellos Benjamin também sustenta que a ação prevista na Lei n. 7.347/85 não tem mais caráter público do que qualquer outra, seja quanto à legitimação seja quanto ao interesse tutelado, justificando-se o uso da expressão, a esta altura, apenas por estar consagrada (A Insurreição da Aldeia Global contra o Processo Civil Clássico: apontamentos sobre a opressão e a libertação judiciais do meio ambiente e do 
cujos interesses individuais homogêneos buscam tutela pode escolher propor uma ação civil pública ou uma ação coletiva, com ritos e possibilidades diferentes, para obter uma tutela jurisdicional ou se, seja qual for o nome que se dê, trata-se de uma única via coletiva.

No caso, não há dois caminhos para trilhar a via da tutela coletiva, evidentemente. O legislador, ao criar a integração entre as duas leis (arts. 90 e 117 do CDC, como já visto), pretendeu apenas estender, para as outras espécies de relações jurídicas, a tutela coletiva que a Lei n. 8.078/90 instituiu na defesa do consumidor. Não houve a criação, nem era essa a intenção, por óbvio, de duas ações distintas para tutelar o consumidor, muito menos para proteger outros interesses individuais homogêneos ${ }^{218}$.

Se a ação é uma só e considerando que pouco importa o nome dado a ela $^{219}$, importa mesmo saber como funcionam, em conjunto, na regência das ações em defesa de interesses individuais homogêneos, a Lei da Ação Civil Pública e o CDC ${ }^{220}$.

Em síntese, na tutela de interesses individuais homogêneos, o procedimento é o do Código de Processo Civil, estatuto processual geral, expressamente aplicável às ações coletivas ${ }^{221}$, parcialmente derrogado pelas disposições dessas duas leis, por tratarem especificamente da tutela coletiva. Tratando-se de tutela jurisdicional de interesses individuais homogêneos relativos às relações de consumo, são aplicáveis todos os dispositivos da Lei n. 7.347/85 que não contrariarem o disposto no CDC, por força do art. 90 desse estatuto. Cuidando-se de defesa em juízo de interesses individuais

consumidor, p. 54. Biblioteca Digital do Superior Tribunal de Justiça, disponível em <http://bdjur.stj.gov.br/dspace/handle/2011/8688>, acesso em 30/10/2008).

${ }^{218} \mathrm{O}$ art. 99 do CDC confirma esse entendimento, ao cogitar somente de concurso de créditos decorrentes de condenação prevista na Lei da Ação Civil Pública e de indenizações pelos prejuízos individuais resultantes do mesmo evento danoso.

${ }^{219}$ Denominar uma ação, na jurisdição coletiva ou na singular, com um nome impróprio, sob qualquer ponto de vista, não pode ser motivo de indeferimento da petição inicial, evidentemente, embora isso já tenha sido verdadeiro no passado, na Roma antiga, "em que era de absoluto rigor o emprego da 'verba certa" (Rodolfo de Camargo Mancuso, Ação civil pública. $5^{\mathrm{a}}$ ed. rev. atual. amp. São Paulo: Editora Revista dos Tribunais, 1997, p. 19).

${ }^{220}$ Também defendendo ser "inócua em termos práticos e teóricos" a polêmica a respeito da denominação ação civil pública ou ação coletiva, Márcio Flavio Mafra Leal (Ações Coletivas: história, teoria e prática. Porto Alegre: Sergio Antonio Fabris Editor, 1998, p. 188).

${ }^{221}$ Art. 19 da Lei n. 7.347/85 e art. 90 da Lei n. 8.078/90. 
homogêneos não concernentes às relações de consumo, são aplicáveis todas as disposições do CDC que não contrariarem a Lei n. 7.347/85, em virtude do art. 21 dessa lei ${ }^{222}$.

São exemplos de disposições da Lei n. 7.347/85 não contrariadas pelo CDC, portanto, aplicáveis à tutela de interesses individuais homogêneos de consumidores: a previsão de ação cautelar $\left(\operatorname{art.~} 4^{\circ}\right)^{223}$; o direito de obter, mediante requerimento (requisição, tratando-se do Ministério Público), no prazo de 15 dias, certidões e informações necessárias à propositura da ação (art. $8^{\circ}$, caput); a instauração de inquérito civil pelo Ministério Público (art. 8, parágrafo $1^{\circ}$ ); o requerimento, de pessoa jurídica de direito público ao tribunal a que competir o recurso, de sustação da execução de medida liminar; a concessão de efeito suspensivo aos recursos para evitar dano irreparável; entre outras $^{224}$. Por outro lado, é possível citar, como exemplos de dispositivos da Lei n. 7.347/85 que contrariam o CDC, inaplicáveis à tutela de interesses individuais homogêneos típicos das relações de consumo, portanto, os seguintes: a atribuição de competência para o foro do local do dano, em qualquer circunstância (art. $2^{\circ}$ ), pois há regra específica no CDC para a hipótese de danos de âmbito nacional ou regional (art 93, inciso II); o litisconsórcio entre Ministérios Públicos (art. $5^{\circ}$, parágrafo $5^{\circ}$ ), tendo em vista que dispositivo semelhante no âmbito do CDC foi vetado (art. 82, parágrafo $\left.2^{\circ}\right)^{225}$; e a limitação territorial dos efeitos "erga omnes" da coisa julgada (art. 16, na redação dada pela Lei n. 9.494/97).

\footnotetext{
${ }^{222} \mathrm{O}$ art. 89 do Código de Defesa do Consumidor dispunha que "as normas deste Título aplicam-se, no que for cabivel, a outros direitos ou interesses difusos, coletivos e individuais homogêneos, tratados coletivamente". Se esse dispositivo não tivesse sido vetado, o Código de Defesa do Consumidor prevaleceria sempre quando em confronto com a Lei da Ação Civil Pública, tratasse o processo coletivo de interesses individuais homogêneos decorrentes de relação de consumo ou não. Evidentemente, outras leis especiais que contenham norma dispondo diferentemente prevalecerão, dentro da sua área de aplicação, como a Lei $n$. 7.913/89, já mencionada.

${ }^{223}$ Embora haja a previsão do art. 83 do CDC, isto é, "para a defesa dos direitos e interesses protegidos por este código são admissíveis todas as espécies de ações capazes de propiciar sua adequada e efetiva tutela".

${ }^{224}$ No mesmo sentido, Nelson Nery Júnior (In: GRINOVER, Ada Pellegrini et al. Código brasileiro de defesa do consumidor comentado pelos autores do anteprojeto. $5^{\text {a }}$ ed. rev. atual. amp. Rio de Janeiro: Forense Universitária, 1998, p. 773).

${ }^{225}$ Nesse sentido, Rodolfo de Camargo Mancuso (In: OLIVEIRA, Juarez de (coord.), Comentários ao Código de Proteção ao Consumidor. São Paulo: Saraiva, 1991, p. 312). É bem verdade que o dispositivo vetado era impreciso, porque o Ministério Público é uno (art. 127, parágrafo $1^{\circ}$, da Constituição Federal), cabendo falar em eventual atribuição de poderes de representação desse órgão, não em litisconsórcio entre ramos da mesma instituição (nesse sentido, Kazuo Watanabe, in GRINOVER, Ada Pellegrini et al. Código brasileiro de defesa do consumidor comentado pelos autores do anteprojeto. $5^{\mathrm{a}}$ ed. rev. atual. amp. Rio de Janeiro: Forense Universitária, 1998, p. 645).
} 
São exemplos de disposições do CDC não contrariadas pela Lei n. 7.347/85, vale dizer, incidem na tutela de interesses individuais homogêneos não decorrentes de relações de consumo: a definição dos interesses individuais que podem ser objeto de tutela coletiva (art. 81, inciso III); a obrigatoriedade de publicação de edital para conhecimento dos interessados (art. 94); a previsão de condenação genérica (art. 95); a possibilidade de liquidação e execução individual ou coletiva (arts. 97 e 98) ${ }^{226}$; e a disciplina da coisa julgada (art. 103, inciso III e parágrafo $2^{\circ}$ ). Porém, existem normas do CDC que, por contrariarem a Lei da Ação Civil Pública, não incidem nas ações coletivas de defesa de outros interesses individuais homogêneos, como a atribuição de legitimidade a entidades e órgãos públicos da administração pública sem personalidade jurídica (art. 82, inciso III) e a inversão do ônus da prova (art. 6, inciso VIII) ${ }^{227}$.

\section{3 - Problemas antigos e a legislação vigente}

\subsection{1 - A representação dos ausentes}

O problema da legitimidade da ação coletiva é crucial e teve de ser enfrentado desde que a legislação brasileira se voltou à regulação do processo coletivo. Se, como entende Antonio Gidi, "ação coletiva é a ação proposta por um legitimado autônomo (legitimidade), em defesa de um direito coletivamente considerado (objeto), cuja imutabilidade do comando da sentença atingirá uma comunidade ou coletividade (coisa julgada) ${ }^{2228}$, então a questão da legitimação é central na tutela coletiva de interesses individuais homogêneos. Lembra José Marcelo Menezes Vigliar que "os dois grandes problemas da tutela jurisdicional coletiva, conforme também muito bem ressaltado por Cândido Rangel Dinamarco, repousam nos extremos lógicos dessa atividade jurisdicional

\footnotetext{
226 Nesse caso não prevalece a disposição do art. 13 da Lei da Ação Civil Pública porque não há uma contradição efetiva. A disposição determinando invariavelmente a reversão a um fundo da condenação em dinheiro se dirige, obviamente, à tutela de interesses indivisíveis, único objeto original da lei, não se aplicando à tutela de interesses individuais homogêneos. Tratando-se de execução de condenação relativa à reparação de interesses individuais homogêneos violados, a Lei da Ação Civil Pública é omissa.

227 Mesmo porque o art. 21 da Lei da Ação Civil Pública só estabelece a incidência das disposições processuais do CDC à tutela de interesses individuais homogêneos em geral se contidos no seu Título III, e a inversão do ônus probatório está no Título I. Nesse sentido, Luis Paulo da Silva Araújo Filho, ressalvando porém que "a possibilidade de aplicação pelo juiz das regras de experiência (art. 335 do CPC) pode levar a resultado prático simílimo à inversão do 'onus probandi"” (Ações coletivas: a tutela jurisdicional dos direitos individuais homogêneos. Rio de Janeiro: Forense, 2000, p. 108 e nota 15).

${ }^{228}$ Coisa julgada e litispendência em ações coletivas. São Paulo: Saraiva, 1995, p. 16.
} 
do Estado, que se dá, invariavelmente, através do processo: as considerações acerca da legitimação para agir (no início da existência da relação jurídico-processual) e da coisa julgada material (ao final da atividade desenvolvida, e que é prevista como uma das garantias constitucionais do cidadão, na forma do inciso XXXVI do art. $5^{\circ}$ da CF)"229.

Por esse prisma, convém lembrar a discussão, já mencionada neste trabalho, a respeito da possibilidade de controle judicial da representatividade adequada, defendida sob o fundamento da garantia do princípio do devido processo legal na sua dimensão coletiva $^{230}$. Despiciendo, portanto, demonstrar a importância da matéria; necessário apenas descrever e comentar o regime de legitimação coletiva sob o enfoque da tutela dos interesses individuais homogêneos.

Também foi visto que, ao contrário da disciplina do Direito norteamericano, que inspirou o projeto de lei que veio a se transformar na Lei $n$. 7.347/85, o legislador optou por atribuir legitimação a determinados entes mediante a instituição de presunção de que são representantes adequados das coletividades titulares dos interesses coletivos a serem defendidos. Assim, dispõe o art. $5^{\circ}$ da Lei da Ação Civil Pública que " $a$ ação principal e a cautelar poderão ser propostas pelo Ministério Público, pela União, pelos Estados e Municípios", assim como "por autarquia, empresa pública, fundação, sociedade de economia mista ou por associação", esta última desde que "esteja constituída há pelo menos um ano, nos termos da lei civil" e "inclua entre suas finalidades institucionais a proteção ao meio ambiente, ao consumidor, à ordem econômica, à livre concorrência, ou ao patrimônio artístico, estético, histórico, turístico e paisagístico". O art. 82 do Código de Defesa do Consumidor, com palavras ligeiramente diferentes, estipula que são legitimadas "concorrentemente" as mesmas pessoas jurídicas, acrescentando apenas que se legitimam também "as entidades e órgãos da Administração Pública, direta ou indireta, ainda que sem personalidade jurídica, especificamente destinados à defesa dos interesses e direitos protegidos por este código".

Como se vê, a legitimação é do tipo concorrente e disjuntiva, além de exaustiva $^{231}$. Concorrente no sentido de a legitimação ser autônoma, independente e

\footnotetext{
${ }^{229}$ Interesses individuais homogêneos e seus aspectos polêmicos. São Paulo: Saraiva, 2003, p. 37.

${ }^{230} \mathrm{~V}$. item 4.2.1, retro.

231 Antonio Gidi prefere usar a expressão "exclusiva", apesar da aparente contradição com o qualificativo "concorrente", que, no caso, tem o significado de "não-exclusiva", porque a palavra está sendo usada em
} 
inclusiva, isto é, a legitimação de cada entidade não exclui a legitimação de outra; disjuntiva no sentido de simples, singular, não complexa, ou seja, cada legitimado pode propor a ação sem o concurso de qualquer outro; exaustiva porque nenhuma outra pessoa ou entidade despersonalizada pode ser legitimada, o rol legal exaure as possibilidades. Fica assim excluída, de lege lata, a possibilidade de uma pessoa física propor ação para tutela de interesses coletivos, como é a regra no sistema norte-americano.

O Código de Defesa do Consumidor autoriza também o juiz a dispensar o requisito da pré-constituição para o fim de reconhecer a legitimidade das associações, desde que "haja manifesto interesse social evidenciado pela dimensão ou característica do dano, ou relevância do bem jurídico a ser protegido"232. Dessa maneira, tal disposição reforça a tese de que o legislador não veda totalmente o controle judicial da representatividade adequada ${ }^{233}$, além de confirmar a relevância do bem jurídico a ser defendido e a gravidade da sua violação como indicadores do interesse social da tutela coletiva $^{234}$.

4.3.2 - Os limites subjetivos da coisa julgada coletiva

O regime da coisa julgada constitui o outro problema crucial da tutela coletiva, ao lado da legitimação, como mencionado no tópico anterior. É da natureza da ação coletiva que a sentença produza efeitos sobre todos os membros do grupo, indiferentemente entre os que, eventualmente, tenham sido partes ou que não o foram. Por essa razão podemos dizer que, se a sentença só produz efeitos entre as partes, de ação coletiva não se trata. Antonio Gidi explica que "é da própria definição da ação coletiva que sua sentença diga respeito a um grupo de pessoas (titulares do direito objetivo do processo coletivo). A coisa julgada coletiva tem efeito ultra partes (erga omnes). Uma

dois sentidos análogos, porém sensivelmente diversos (Coisa julgada e litispendência em ações coletivas. São Paulo: Saraiva, 1995, p. 38-39). Ainda que não haja efetiva contradição entre as duas qualidades da legitimação para a ação coletiva, já que o sentido é de inclusão de todos os integrantes do rol legal e exclusão de todos os demais, é mais conveniente o uso da expressão "exaustiva" para significar que não pode haver outros legitimados além daqueles expressamente designados na lei.

${ }^{232}$ Art. 82, parágrafo $1^{\circ}$.

${ }^{233} \mathrm{~V}$. item 4.2.1.

${ }^{234}$ V. capítulo 3, item, 3.4.2. 
sentença limitada às partes em juízo vai de encontro à essência do processo civil coletivo, $^{, 235}$.

A problemática da coisa julgada no processo coletivo, já se vê, decorre do fato de que a coisa julgada projetará seus efeitos sobre quem não esteve pessoalmente em juízo, situação anômala que exige um regramento cuidadoso. Mas não existe um único sistema de vinculação aos efeitos da coisa julgada no Direito Comparado.

Três sistemas têm sido mais utilizados, explica Aloísio Gonçalves de Castro Mendes: o de inclusão, o de exclusão e o secundum eventum litis. O primeiro, pelo qual "a pessoa interessada precisa manifestar expressamente a sua vontade de ser atingida pelos efeitos do pronunciamento judicial coletivo, é também conhecido pela expressão inglesa 'opt-in', diante da necessidade de opção pelo ingresso no grupo atrelado à decisão. É o que se passa, por exemplo, na Inglaterra e na China". O sistema de exclusão "está baseado na exigência de representação adequada e na comunicação prévia aos interessados que, em geral, dentro de prazo fixado pelo órgão judicial, deverão requerer a sua exclusão (opt-out) em relação à eficácia dos provimentos proferidos no processo metaindividual. Do contrário, estará, a priori, vinculado ao pronunciamento. É o modelo adotado, atualmente, verbi gratia, nos Estados Unidos, no Canadá e na Austrália”.

Por último, os efeitos da coisa julgada podem ser condicionados ao resultado da sentença em relação aos interesses coletivos, isto é, a coisa julgada secundum eventum litis. O condicionamento pode ser absoluto, quer dizer, não há vinculação se a sentença for desfavorável aos interesses coletivos e há vinculação se for favorável; ou relativo ao motivo de eventual julgamento de improcedência, ou seja, não há vinculação se a sentença for desfavorável por falta de provas, havendo vinculação se o julgamento de improcedência for baseado em qualquer outro fundamento ou ainda se a sentença for favorável, como ocorre em Portugal e também na ação popular brasileira ${ }^{236}$.

\footnotetext{
${ }^{235}$ A class action como instrumento de tutela coletiva dos direitos. São Paulo: Editora Revista dos Tribunais, 2007, p. 282.

236 Aloísio Gonçalves de Castro Mendes, Ações coletivas: no direito comparado e nacional. São Paulo: Editora Revista dos Tribunais, 2002, p.187-188.
} 
A legislação brasileira tratou o tema de maneira relativamente inovadora e complexa, tentando adaptar o instituto às peculiaridades da nossa realidade. Quando se trata de interesses individuais homogêneos, conforme definidos no art. 81, inciso III, do Código de Defesa do Consumidor, dispõe o art. 103, inciso III, desse estatuto que "nas ações coletivas de que trata este código, a sentença fará coisa julgada [...] erga omnes, apenas no caso de procedência do pedido, para beneficiar todas as vítimas e seus sucessores", estipulando o parágrafo $2^{\circ}$ que "na hipótese prevista no inciso III, em caso de improcedência do pedido, os interessados que não tiverem intervindo no processo como litisconsortes poderão propor ação de indenização a título individual, ${ }^{237}$.

A doutrina não discrepa sobre o significado do dispositivo. No plano da jurisdição coletiva, a sentença torna-se imutável em face de todos os interessados, sejam partes ou terceiros (não intervenientes), qualquer que tenha sido o julgamento, procedência ou improcedência do pedido. Nova ação coletiva não poderá ser ajuizada, pelo mesmo ou por qualquer outro legitimado, nem mesmo na hipótese de surgimento de nova prova.

No plano da jurisdição singular, a situação é bem outra. A questão discutida no processo coletivo decidido por sentença transitada em julgado pode ser novamente discutida na jurisdição singular por qualquer interessado, desde que não tenha intervindo na ação coletiva como litisconsorte ${ }^{238}$.

Note-se que, no sistema brasileiro, não existem as figuras do right to opt in nem do right to opt out, que seriam instrumentos de eficácia enormemente duvidosa num país de dimensões geográficas e demográficas continentais com as dificuldades de acesso à informação por grandes contingentes populacionais, em decorrência dos enormes desníveis sociais. Mas também não houve a adoção do sistema da coisa julgada secundum eventum litis, nem mesmo relativa, no caso dos interesses individuais homogêneos. No plano coletivo, a coisa julgada espraia os seus efeitos sempre e sobre todos. É apenas no plano individual que a imutabilidade dos efeitos da sentença só alcança os interessados se a

\footnotetext{
${ }^{237} \mathrm{O}$ art. 16 da Lei n. 7.347/85 dispunha apenas que a sentença faria coisa julgada "erga omnes", salvo na hipótese de sentença de improcedência por insuficiência de provas. Posteriormente, o dispositivo foi alterado para incluir uma limitação territorial bastante polêmica. A propósito, v. item 5.3.1.

${ }^{238}$ Art. 94 da Lei n. 8.078/90.
} 
sentença for favorável ${ }^{239}$ e, sendo desfavorável, apenas os que tiverem adquirido a condição de parte do processo coletivo ${ }^{240}$.

\subsection{3 - A resistência do Poder Executivo à tutela coletiva}

Desde a aprovação da Lei n. 7.347/85, o Poder Executivo vem demonstrando uma forte resistência à tutela coletiva. O motivo, sem dúvida, é o alcance da coisa julgada coletiva, já que, como visto, se a sentença for favorável aos interesses coletivos, projeta seus efeitos sobre todos os interessados, muitas vezes um contingente de expressão regional ou mesmo nacional. Considerando que muitas vezes o próprio poder público está na condição de réu das ações coletivas ${ }^{241}$, a perspectiva de uma decisão que adquira o caráter de indiscutibilidade em face de qualquer interessado em todo o país parece repelir os governantes, que se utilizam dos amplos poderes de iniciativa legislativa para tentar neutralizar a abrangência da tutela coletiva ${ }^{242}$.

Já na aprovação da Lei da Ação Civil Pública sobreveio o veto presidencial sobre o inciso IV do art. $1^{\circ}$, art. $4^{\circ}$ e inciso II do art. $5^{\circ}$, que previam a aplicabilidade dessa ação para responsabilidade por danos causados a "qualquer outro interesse difuso ou coletivo",243, sob o fundamento de que isso geraria "insegurança jurídica, em detrimento do bem comum, que decorre da amplíssima e imprecisa abrangência da expressão". Ao mesmo tempo em que a mensagem do veto reconhecia ser “importante, neste momento, que, em relação à defesa e preservação dos direitos dos consumidores, assim como do patrimônio ecológico, natural e cultural do País, a tutela jurisdicional dos interesses difusos deixe de ser uma questão meramente acadêmica para

\footnotetext{
${ }^{239}$ Efeito mais corretamente denominado como "transporte 'in utilibus' da coisa julgada coletiva".

${ }^{240}$ Mesmo no caso dos interesses difusos e coletivos (art. 103, incisos I e II), não há coisa julgada secundum eventum litis absoluta, mas apenas condicionada: só não haverá formação de coisa julgada nos casos de sentença desfavorável se o julgamento tiver sido baseado em produção probatória insuficiente. A diferença de tratamento entre os interesses essencialmente coletivos e os individuais homogêneos será mais bem estudada no capítulo 5 .

${ }^{241}$ V. capítulo 4, item 4.4.2.

242 A propósito, v. Marilena Lazzarini, As investidas contra as ações civis públicas. In: LUCON, Paulo Henrique dos Santos (org.). Tutela coletiva. São Paulo: Atlas, 2006, p. 159-162.

${ }^{243}$ Dispositivos que, se aprovados, poderiam ter dado ensejo à proteção de interesses individuais coletivos desde aquela época, conforme o posicionamento que a jurisprudência tomasse. Com o veto, a tutela ampla dos interesses individuais homogêneos teve de aguardar a aprovação do Código de Defesa do Consumidor, mais de cinco anos depois.
} 
converter-se em realidade juridico-positiva, de verdadeiro alcance e conteúdo sociais", os outros interesses difusos ou coletivos que não pudessem ser especificados deveriam aguardar autorização para serem tutelados ${ }^{244}$. A motivação implícita do veto aparenta ser muito mais um movimento em defesa do Governo do que da sociedade, diante do receio do que pudesse vir a ser entendido, pela jurisprudência, como "outro interesse difuso ou coletivo".

Depois, sobreveio a Medida Provisória n. 1.570-5, de 22/08/97245, que alterou o art. 16 da Lei n. 7.347/85, dispondo que "a sentença civil fará coisa julgada erga omnes, nos limites da competência territorial do órgão prolator, exceto se o pedido for julgado improcedente por insuficiência de provas, hipótese em que qualquer legitimado poderá intentar outra ação com idêntico fundamento, valendo-se de nova prova". $\mathrm{O}$ dispositivo, aparentemente, tentou restringir a coisa julgada mediante a regra de competência do juízo de primeira instância que vier a conhecer da ação coletiva, confundindo os institutos de forma inepta. Conforme esse disciplinamento canhestro, a imutabilidade dos efeitos da sentença coletiva só deve atingir as pessoas cujas pretensões sejam de competência do mesmo órgão prolator.

A doutrina foi unânime na crítica à opção legislativa, por falta de técnica, mas se dividiu quanto ao acolhimento da norma. Ora apontou inconstitucionalidade da medida, por violação do princípio da isonomia ${ }^{246}$, ora apontou a inocuidade da norma, tendo em vista que os limites territoriais seriam aqueles do art. 93 do Código de Defesa do Consumidor $^{247}$, e ora defendeu a constitucionalidade da medida, ainda que contra a melhor técnica ${ }^{248}$.

\footnotetext{
244 "Eventuais hipóteses rebeldes (sic) à previsão do legislador, mas ditadas pela complexidade da vida social, merecerão a oportuna disciplinação legislativa" (Mensagem n. 359, de 24 de julho de 1985, da Subchefia para Assuntos Jurídicos da Casa Civil da Presidência da República, www.planalto.gov.br/ccivil_03/Leis/Mensagem_Veto/anterior_98/Mvep359-85.htm, acesso em 14/10/2008).

${ }^{245}$ Depois convertida na Lei n. 9.494, de 10/09/97.

${ }^{246}$ V. José Marcelo Menezes Vigliar, Tutela jurisdicional coletiva. $3^{\text {a }}$ ed. São Paulo: Atlas, 2001, p. 177-184.

${ }^{247}$ V. Ada Pellegrini Grinover (Código brasileiro de defesa do consumidor comentado pelos autores do anteprojeto. $5^{\text {a }}$ ed. rev. atual. amp. Rio de Janeiro: Forense Universitária, 1998, p. 723-724). A autora aponta ainda a inaplicabilidade do dispositivo em relação à tutela dos interesses individuais homogêneos, por não constituir o objeto original da Lei n. 7.347/85 e por causa da referência à coisa julgada secundum eventum probationis, só aplicável aos interesses difusos e coletivos em sentido estrito nos termos do art. 91 do Código de Defesa do Consumidor.

${ }^{248}$ V. Humberto Theodoro Júnior, Algumas observações sobre a ação civil pública e outras ações coletivas. In: Revista Síntese de Direito Civil e Processual Civil n. 9, Porto Alegre, jan./fev. 2001, p. 155. O autor
} 
Não obstante as críticas da doutrina, a jurisprudência tem acatado a norma no sentido de considerar válida a restrição dos efeitos da coisa julgada aos limites da competência territorial, entendida como o espaço decorrente da divisão do serviço judiciário em comarcas ou seções judiciárias ${ }^{249}$.

Em seguida, por meio da Medida Provisória n. 2.180-35, de 24/08/2001, inseriram-se no ordenamento jurídico três novas normas restritivas da tutela coletiva, a primeira, de caráter material, afastando a aplicabilidade da ação civil pública para determinadas matérias; a segunda, em prejuízo das associações, e a terceira em face de qualquer legitimado quando a ação coletiva fosse proposta contra entidade pública. De acordo com o novo parágrafo único do art. $1^{\circ}$ da Lei n. $7.347 / 85$, “não será cabível ação civil pública para veicular pretensões que envolvam tributos, contribuições previdenciárias, o Fundo de Garantia do Tempo de Serviço - FGTS ou outros fundos de natureza institucional cujos beneficiários podem ser individualmente determinados".

Pelo novo art. $2^{\circ}$-A da Lei n. 9.494/97, estipulou-se que " a sentença civil prolatada em ação de caráter coletivo proposta por entidade associativa, na defesa dos interesses e direitos dos seus associados, abrangerá apenas os substituídos que tenham, na data da propositura da ação, domicílio no âmbito da competência territorial do órgão prolator". O parágrafo único dispõe que "nas ações coletivas propostas contra a União, os Estados, o Distrito Federal, os Municípios e suas autarquias e fundações, a petição inicial deverá obrigatoriamente estar instruída com a ata da assembléia da entidade associativa que a autorizou, acompanhada da relação nominal dos seus associados e indicação dos respectivos endereços".

Igualmente acerba foi a crítica doutrinária à iniciativa legislativa oriunda do Poder Executivo, qualificada de inócua e duplamente inconstitucional: do ponto de vista formal, por falta de relevância e urgência da respectiva medida provisória; no respeitante ao aspecto material, por violação dos princípios da razoabilidade, da proporcionalidade e

refuta a tese de que os limites da competência territorial sejam dados pelo art. 93 da Lei n. 8.078/90, sustentando que ali está regulada "apenas a competência para certas ações coletivas, em função do objeto da lide, não a extensão da "competência territorial".

${ }^{249}$ V. EREsp n. 293407/SP, Corte Especial, DJ de 01/08/2006; REsp n. 838.978/MG, Primeira Turma, DJ de 14/12/2006 e Resp n. 422.671/RS, Primeira Turma, DJ de 30/11/2006. 
da inafastabilidade do controle judicial ${ }^{250}$. Mas, da mesma forma que as demais iniciativas governamentais de restrição do âmbito da tutela coletiva, a limitação dos efeitos da sentença em ação coletiva proposta por associação aos associados domiciliados nos limites da competência territorial do órgão prolator não foi considerada inconstitucional nem inócua pela jurisprudência do Superior Tribunal de Justiça ${ }^{251}$, embora aplique o dispositivo restritivamente, isto é, apenas às ações propostas "na defesa dos interesses e direitos dos seus associados", quer dizer, ajuizadas com base nos poderes conferidos pelo inciso XXI do art. $5^{\circ}$ da Constituição Federal, não as ações propriamente coletivas, que, quando propostas por associações, o são na defesa dos interesses e direitos não só dos seus associados, mas de todas as pessoas cujos interesses individuais possuam a mesma origem.

Tratando-se de restrições legais à tutela coletiva, as questões mais importantes colocadas para os operadores do Direito, pelo menos os que não concordam com tais inovações, provavelmente são as expectativas de novas limitações como essas e como enfrentar essa tendência.

Em primeiro lugar, pode-se dizer, no mínimo, ser pouco provável que o Poder Executivo, seja qual for o governo, mude de intenção ou de atitude, admitindo um controle judicial mais facilitado que possa recair sobre a própria conduta de seus órgãos. Enquanto puder, o Poder Executivo vai procurar manter e aprofundar os instrumentos legais de restrição da tutela coletiva sob qualquer aspecto em que ela possa vir a contrariar os seus interesses. As normas constitucionais prevendo e estimulando a tutela coletiva têm se mostrado francamente insuficientes para deter essa tendência, porque sempre será possível confrontá-las com o (alegado) interesse público, também de índole constitucional, que as normas restritivas visariam proteger. Da relatividade do significado, em cada hora e em cada lugar, de interesse público, é muito difícil retirar qualquer conclusão categórica que permita invalidar qualquer uma dessas iniciativas.

Em segundo lugar, diante dessa situação, não há muita esperança de que seja possível deter essa escalada por meio do Poder Judiciário, com base em instrumentos tão limitados como o princípio da razoabilidade ou o princípio da proporcionalidade,

\footnotetext{
${ }^{250}$ V. Pedro Lenza, Teoria geral da ação civil pública. São Paulo: Editora Revista dos Tribunais, 2003, p. 277 .

${ }^{251}$ V. AGRESP n. 1029223/PE, Sexta Turma, DJE de 29/09/2008, Relator Min. Paulo Gallotti; REsp n. 665947/SC, Primeira Turma, DJ de 12/12/2005, Relator Min. José Delgado.
} 
diante da força representada pelas medidas provisórias, para não falar no amplo poder de iniciativa de leis e no irrestrito e praticamente inconfrontável poder de veto. É possível organizar inúmeros seminários e congressos para verberar contra a ilogicidade, reprovar a falta de técnica ou censurar a ausência de compromisso para com o desenvolvimento da tutela coletiva; apesar de tudo isso, o Poder Executivo, absolutamente indiferente, prosseguirá rumo aos seus objetivos.

Também tem se mostrado inútil a disposição de lançar imputações de inconstitucionalidade dessas alterações. Depois de aprovada uma proposta legislativa como as mencionadas acima, visando restringir a tutela coletiva, muito pouco pode ser feito além de interpretá-la restritivamente, muitas vezes por força da sua própria falta de técnica, salvo as raras hipóteses de afronta constitucional efetivamente reconhecidas.

Muito melhor seria feito se as propostas de lege ferenda, como as mencionadas no próximo tópico, tentassem antecipar os pontos sensíveis da tutela coletiva no que toca à Administração Pública e os tratasse de maneira diferenciada, conforme o caso. Ou, melhor ainda, se fosse promovido um trabalho de convencimento dos membros do Poder Legislativo e dos altos escalões do Poder Executivo sobre a importância da abrangência e efetividade da tutela coletiva, especialmente no contexto da solução dos problemas de congestionamento do Poder Judiciário e acesso à justiça dos que hoje estão excluídos do sistema jurisdicional.

\section{4 - Problemas atuais e as propostas de lege ferenda}

\subsection{1 - As propostas de Código de Processo Coletivo e suas inovações}

Diante dos problemas, dúvidas e hesitações que a tutela coletiva tem suscitado, não têm faltado propostas de alteração da legislação, especialmente com o fim de substituir o sistema composto pela Lei da Ação Civil e pelo Código de Defesa do Consumidor, seja nas ações que envolvem interesses individuais homogêneos, seja nas ações relacionadas com interesses difusos e coletivos em sentido estrito. Para tanto, existe uma forte tendência a considerar conveniente e oportuna a aprovação de um código 
brasileiro de processo coletivo ${ }^{252}$, muitas vezes envolvendo até mesmo outras ações que também podem ser consideradas coletivas, mas cuja regulação conjunta nem sequer havia sido cogitada antes, como a ação popular (Lei n. 4.717/65), o mandado de segurança coletivo (previsto pela primeira vez na Constituição Federal de 1988 e cujo rito é o da Lei n. 1.533/51), a ação protetiva da pessoa portadora de deficiência (Lei n. 7.853/89), a ação protetiva dos investidores do mercado de valores mobiliários (Lei n. 7.913/89), a ação protetiva dos interesses de crianças e adolescentes (art. 208 e seguintes da Lei n. 8.069/90), a ação de improbidade administrativa (Lei n. 8.429/92), a ação repressiva das infrações contra a ordem econômica (arts. 29 e 83 da Lei n. 8.884/94) e a ação protetiva do idoso (Lei n. 10.741/2003).

As principais propostas a serem destacadas são as do Instituto IberoAmericano de Direito Processual (o "Código Modelo de Processos Coletivos para IberoAmérica", aprovado em 2004), dos programas de pós-graduação stricto sensu da Universidade do Estado do Rio de Janeiro e da Universidade Estácio de Sá (um anteprojeto de "Código Brasileiro de Processos Coletivos") e do programa de pós-graduação stricto sensu da Universidade de São Paulo (também um anteprojeto de "Código Brasileiro de Processos Coletivos") ${ }^{253}$. Mais recentemente, no âmbito da Secretaria de Reforma do Judiciário do Ministério da Justiça, surgiu também uma proposta de projeto de lei para regulamentar a tutela coletiva em geral, substituindo-se o sistema formado, principalmente, pelas Leis n. 7.347/85 e 8.078/90, proposta que ficou conhecida pela denominação "Sistema Único Coletivo".

O Código Modelo teve por objetivo servir como um "repositório de princípios" e um "modelo concreto para inspirar as reformas, de modo a tornar mais homogênea a defesa dos interesses e direitos transindividuais em países de cultura

\footnotetext{
${ }^{252}$ Essa opinião, naturalmente, não é unânime, sendo sustentável o entendimento no sentido de que a Lei n. 7.347/85 é relativamente nova, mais recente no regime constitucional atual e mais recente ainda formando o microssistema com o Código de Defesa do Consumidor, e que a sua total substituição constitui enorme risco, se não houver um maior aprofundamento da discussão sobre as propostas até agora apresentadas.

${ }^{253} \mathrm{O}$ objetivo da análise a ser feita neste trabalho não é o de esgotar o repertório de propostas legislativas na área da tutela coletiva nem o de avaliá-las exaustivamente, mas apenas formar um painel das propostas sobre os temas mais relevantes, sobre o qual seja possível elaborar um cotejo das vantagens e desvantagens das principais soluções elaboradas. Outro anteprojeto digno de nota é o de Antonio Gidi (Código de processo civil coletivo - um modelo para países de direito escrito. In: MAZZEI, Rodrigo; NOLASCO, Rita (coord.). Processo civil coletivo. São Paulo: Quartier Latin, 2005, p. 758-776).
} 
jurídica comum" ${ }^{254}$. Prevê, em seus 41 artigos, diversos instrumentos típicos dos modelos jurídicos dos sistemas da civil law, mas também adota dispositivos próprios da class action norte-americana. Adota o modelo bipartido de classificação dos interesses transindividuais, dividindo-os em difusos e individuais homogêneos (art. $1^{\circ}$ ); impõe expressamente o requisito da representatividade adequada do legitimado (art. $2^{\circ}$, inciso I), cujos critérios exemplifica (art. $2^{\circ}$, parágrafo $2^{\circ}$ ), bem como, no caso dos interesses individuais homogêneos, a predominância das questões comuns sobre as individuais e a utilidade da tutela coletiva (art. $2^{\circ}$, parágrafo $1^{\circ}$ ); confere legitimidade não apenas ao Ministério Público e às pessoas jurídicas de direito público e associações, mas também a qualquer pessoa física para a tutela dos interesses difusos e a qualquer membro do grupo, categoria ou classe para a defesa dos interesses individuais homogêneos (art. $3^{\circ}$ ); permite a alteração de boa-fé do pedido, sem anuência do réu, mesmo depois da citação, garantido o contraditório (art. 10, parágrafo $2^{\circ}$ ); prevê uma decisão saneadora em audiência preliminar, não obtida a conciliação, que inclui expressamente uma espécie de certificação da ação como coletiva (art. 11); autoriza a inversão do ônus da prova desde que antes de encerrada a fase probatória (art. 12).

Para a defesa de interesses individuais homogêneos, regula a ação coletiva de responsabilidade civil, prevendo a possibilidade de identificação dos membros do grupo, categoria ou classe apenas na fase de liquidação e execução do julgado (art. 20); prevê a sentença genérica na sentença condenatória de procedência do pedido, se necessário (art. 22); autoriza a execução individual ou coletiva (arts. 23 e 24); determina a destinação, a um fundo estatal, da parcela da indenização por danos causados não reclamados pelos lesados. No capítulo da coisa julgada, afasta a litispendência entre ação coletiva e ações individuais, assim como o aproveitamento da sentença coletiva benéfica aos interessados que não suspenderem suas ações individuais em cujos autos for noticiada a propositura da ação coletiva (art. 31); estende os efeitos da coisa julgada erga omnes, exceto, no caso de sentença de improcedência, para os interesses individuais homogêneos, em relação às ações individuais, e para os interesses difusos, se motivada por insuficiência de provas (art. 33). Para finalizar, regula a ação coletiva passiva (arts. 35 a 38) e recomenda a especialização de juízos (art. 40).

${ }^{254}$ Cf. "Exposição de motivos" (In: GRINOVER, Ada Pellegrini; MENDES, Aloísio Gonçalves de Castro; WATANABE, Kazuo. Direito processual coletivo e o anteprojeto de código brasileiro de processos coletivos. São Paulo: Editora Revista dos Tribunais, 2007, p. 423). 
O Anteprojeto de Código Brasileiro de Processos Coletivos da UERJ/Unesa, elaborado a partir de debates ocorridos durante os anos de 2004 e 2005, teve por escopo inicial formular sugestões de melhoria de anteprojeto semelhante que já havia sido iniciado na Universidade de São Paulo, mas "acabou evoluindo para uma reestruturação do texto original, com o intuito de se oferecer uma proposta coerente (...) para ser cotejada e discutida" ${ }^{, 55}$. Inclui também diversas soluções brasileiras, como a coisa julgada secundum eventum litis, mas também institutos tranladados do Direito norteamericano, entre os quais se destaca a necessidade de exclusão da ação coletiva para não ser atingido pela coisa julgada (opt out).

O anteprojeto do Rio de Janeiro, com 60 artigos, adota o critério tripartido de classificação dos interesses metaindividuais, ou seja, difusos, coletivos em sentido estrito e individuais homogêneos (art. $2^{\circ}$ ); dá prioridade de tramitação para as ações coletivas (art. $4^{\circ}$ ); recomenda a especialização de juízos (art. $5^{\circ}$ ); impõe a litispendência da primeira ação coletiva sobre todas as outras que tenham o mesmo pedido, causa de pedir e interessados (art. $7^{\circ}$ ); prevê a representatividade adequada como requisito da ação coletiva (art. $8^{\circ}$, inciso I), indicando os critérios de aferição (art. $8^{\circ}$, parágrafo $1^{\circ}$ ) e impondo a análise da sua existência a qualquer tempo (art. $8^{\circ}$, parágrafo $2^{\circ}$ ); atribui legitimação, além do Ministério Público, a pessoas jurídicas de direito público e associações, também a qualquer pessoa física para defender interesses difusos e a qualquer membro do grupo, categoria ou classe para tutelar interesses coletivos em sentido estrito e individuais homogêneos (art. $9^{\circ}$ ); impõe a obrigatoriedade de o juiz comunicar o Ministério Público e outros possíveis legitimados sobre a existência de processos repetitivos (art. 10); permite a alteração justificada e de boa-fé do pedido sem anuência do réu, mesmo depois da citação, garantido o contraditório (art. 15); interrompe a prescrição das pretensões individuais e coletivas com a citação na ação coletiva (art. 17); prevê uma decisão saneadora incluindo a certificação da ação como coletiva (art. 18, parágrafo $5^{\circ}$, inciso I); estende os efeitos da coisa julgada erga omnes, exceto, no caso de sentença de improcedência, para os interesses individuais homogêneos, em relação às ações individuais dos interessados que não as suspenderam ou requereram exclusão do grupo, e para os interesses difusos e coletivos em sentido estrito, se motivada por insuficiência de provas

${ }^{255}$ Cf. "Exposição de motivos" (In: GRINOVER, Ada Pellegrini; MENDES, Aloísio Gonçalves de Castro; WATANABE, Kazuo. Direito processual coletivo e o anteprojeto de código brasileiro de processos coletivos. São Paulo: Editora Revista dos Tribunais, 2007, p. 434). 
(art. 22, caput e parágrafo $3^{\circ}$ ); estabelece a vedação à limitação da coisa julgada com base na competência territorial do órgão julgador (art. 22, parágrafo $4^{\circ}$ ); determina a reversão da indenização por danos a bem indivisível a fundo de direitos transindividuais, com especificação na sentença sobre a aplicação dos recursos (art. 25); fixa a aplicação preferencial dos recursos do fundo na reconstituição do bem lesado, seguindo-se a minimização da lesão, prevenção ou outras atividades benéficas (art. 29).

No que pertine à ação para defesa de interesses individuais homogêneos, o anteprojeto da UERJ/Unesa propõe a exigência de aferição dos requisitos da predominância das questões comuns e a utilidade da tutela coletiva no caso concreto (art. 30); dispensa de identificação dos interessados pelo autor, podendo ser exigida do réu, se for o caso (art. 31); direito de exclusão (opt out) em prazo fixado pelo juiz ou até a sentença (art. 32); sentença tão líquida quanto possível, incluindo valor uniforme ou fórmula de cálculo, se for possível, assim como a sentença genérica, se necessário (art. 36); preferência pela execução coletiva (art. 38), com pagamento diretamente aos interessados, por depósito bancário em conta a ser aberta em instituição oficial (art. 39); liquidação e execução individuais, destinando-se o produto, se impossível a identificação dos interessados, ao fundo de direitos transindividuais (art. 40). Na parte final, a proposta fluminense inclui previsão da ação coletiva passiva (arts. 42 a 44); da aplicação do código ao mandado de segurança coletivo (arts. 45 e 46), à ação popular (art. 53) e à ação de improbidade administrativa, sem prejuízo das leis especiais (Leis n. 1.533/51, 4.717/65 e 8.429/92); a regulação do mandado de injunção coletivo (arts. 47 a 52); a revogação completa do sistema processual formado pela Lei da Ação Civil Pública e pelo Código de Defesa do Consumidor, além de outros dispositivos processuais de tutela coletiva em leis especiais (art. 58); e a determinação para instalação de órgãos especializados de primeiro e segundo graus de jurisdição para ações coletivas (art. 59).

O anteprojeto de Código Brasileiro de Processos Coletivos da USP foi formulado a partir de debates acadêmicos promovidos de 2003 a $2006^{256}$, bem como consulta a diversos órgãos públicos (entre eles juízes de varas especializadas em processos

\footnotetext{
${ }^{256}$ Como aluno do programa de Pós-Graduação da Faculdade de Direito da Universidade de São Paulo, participei desses debates durante o ano de 2006, quando foram analisadas as críticas ao anteprojeto da USP formuladas pelos Ministérios Públicos de São Paulo, do Paraná e de Minas Gerais, pela Casa Civil da Presidência da República, pela Secretaria de Assuntos Legislativos do Ministério da Justiça, pela Coordenação-Geral da Representação Judicial da Fazenda Nacional, pelo Conselho Federal Gestor do Fundo de Defesa dos Direitos Difusos e pela UERJ/Unesa, por meio do seu próprio anteprojeto, já exposto.
} 
coletivos e membros do Ministério Público da União, do Distrito Federal e de diversos Estados) e associações (IBDP e IDEC). O objetivo foi o de elaborar proposta de aperfeiçoamento do sistema de tutela coletiva a partir das ideias contidas no Código Modelo $^{257}$. Nos seus 52 artigos, na versão de janeiro de 2007, diferencia-se pela enumeração dos princípios que devem reger a tutela coletiva (art. $2^{\circ}$ ) e pela preocupação com a efetividade do processo coletivo, mediante a previsão de dispositivos específicos, como a desconsideração da pessoa jurídica e a possibilidade de arbitragem no caso de bens disponíveis (art. $3^{\circ}$ ). Propõe também a divisão tripartite dos interesses metaindividuais, ressalvando expressamente a possibilidade de controle difuso de constitucionalidade mediante ação coletiva, desde que em sede de questão prejudicial (art. $4^{\circ}$ ); possibilidade de alteração justificada e de boa-fé do pedido, sem anuência do réu, mesmo após a citação, assegurado o contraditório (art. $5^{\circ}$, parágrafo único); determina a reunião de ações coletivas conexas ou continentes (art. $6^{\circ}$ ); afasta os efeitos da coisa julgada coletiva benéfica sobre as ações individuais não suspensas (art. $7^{\circ}$ ); impõe a obrigatoriedade de 0 juiz comunicar o Ministério Público e outros possíveis legitimados sobre a existência de processos repetitivos (art. $8^{\circ}$ ); interrompe a prescrição das pretensões individuais e coletivas com a citação na ação coletiva (art. $9^{\circ}$ ); institui a prioridade na tramitação de ações coletivas $\left(\operatorname{art} .10^{\circ}\right)$; institui a possibilidade de inversão do ônus da prova a qualquer tempo, desde antes do término da fase probatória, respeitado o contraditório (art. 11, parágrafo $3^{\circ}$ ); impõe a obrigação de o juiz explicitar, no dispositivo da sentença de improcedência, se rejeita a demanda por insuficiência de provas (art. 12, parágrafo único); prevê a coisa julgada secundum eventum probationis para qualquer ação coletiva, incluindo aquelas em defesa de interesses individuais homogêneos, bem como o transporte in utilibus da coisa julgada coletiva em defesa de interesses difusos e coletivos para ações individuais de indenização, e a possibilidade de nova ação coletiva no caso de surgimento de prova nova (art. 13); autoriza a fixação de prêmio ao legitimado pessoa física, sindicato, autarquia de fiscalização ou associação cuja atuação na demanda tenha sido relevante, a ser paga pelo fundo de direitos transindividuais (art. 17, parágrafo $3^{\circ}$ ); recomenda a especialização de juízos (art. 18); legitima, além do Ministério Público, órgãos públicos e associações, qualquer pessoa física para a defesa de interesses difusos e qualquer membro do grupo, categoria ou classe para os interesses coletivos ou individuais homogêneos,

${ }^{257}$ Cf. "Exposição de motivos" (In: GRINOVER, Ada Pellegrini; MENDES, Aloísio Gonçalves de Castro; WATANABE, Kazuo. Direito processual coletivo e o anteprojeto de código brasileiro de processos coletivos. São Paulo: Editora Revista dos Tribunais, 2007, p. 449). 
desde que demonstre representatividade adequada, de acordo com os critérios arrolados (art. 20), impondo a análise da sua existência a qualquer tempo (art. 20, parágrafo $2^{\circ}$ ); impõe o requisito da existência de interesse social para a tutela coletiva (art. 20, parágrafo $1^{\circ}$ ); prevê decisão saneadora, se inviável a conciliação, incluindo a certificação da ação como coletiva e a advertência sobre a possibilidade de inversão do ônus da prova no momento do julgamento (art. 20, parágrafo $5^{\circ}$, inciso $\mathrm{V}$ ); institui preferência pela compensação do dano a interesse indivisível lesado (reconstituição, minimização ou prevenção) sobre o pagamento de indenização (art. 26); regulamenta a composição e gestão do fundo de direitos metaindividuais (art. 27).

Em relação à tutela coletiva de interesses individuais homogêneos, especificamente, o anteprojeto da USP propõe a inclusão dos requisitos da predominância das questões comuns sobre as individuais e da utilidade da tutela coletiva, com a dispensa da obrigatoriedade de determinação dos interessados na petição inicial (art. .28); a instituição de um cadastro nacional de processos coletivos (art. 30, parágrafo $1^{\circ}$ ); a instituição de obrigatoriedade da fixação do valor da indenização na sentença, sempre que possível (art. 32, caput), ainda que seja indiretamente, mediante fórmula matemática (art. 32, parágrafo $1^{\circ}$ ), ou, caso contrário, genérica (art. 32, parágrafo $3^{\circ}$ ); a possibilidade de execução individual ou coletiva da sentença genérica (arts. 34 e 35); a liquidação pelos danos globalmente causados para reversão ao fundo de direitos transindividuais, se não houver a habilitação de interessados em número compatível com o dano (art. 36).

Na sua parte final, o anteprojeto da USP dispõe sobre a ação coletiva passiva para tutela de interesses difusos ou coletivos de interesse social (art. 38); regula o mandado de segurança coletivo, sem prejuízo da aplicação da Lei n. 1.533/51; aplica o código à ação popular e à ação de improbidade administrativa, sem prejuízo das Leis n. 4.717/65 e 8.429/92 (art. 44 e 45); dispõe sobre o cadastro nacional de processos coletivos (art. 46); e revoga completamente o sistema processual formado pela Lei da Ação Civil Pública e pelo Código de Defesa do Consumidor, além de outros dispositivos processuais de tutela coletiva contidos em leis especiais (art. 51). 
O anteprojeto da Secretaria de Reforma do Judiciário está atualmente em desenvolvimento por comissão criada pelo ministro da Justiça ${ }^{258}$. Embora se fale em nova lei da ação civil pública para funcionar como norma geral do sistema processual de tutela coletiva, o texto que vem sendo submetido à discussão por profissionais da área constitui proposta muito semelhante, ainda que com algumas diferenças importantes, aos anteprojetos da USP e da UERJ/Unesa, todos desenvolvidos a partir do Código Modelo, com o mesmo objetivo, ou seja, substituir o microssistema processual coletivo formado pela atual Lei da Ação Civil Pública e Código de Defesa do Consumidor e unificar o tratamento do processo coletivo, revogando disposições processuais coletivas esparsas. As principais diferenças referem-se à ausência de legitimação de pessoas físicas ou membros do grupo, categoria ou classe para ajuizar ações coletivas na tutela de interesses respectivamente, difusos ou coletivos e individuais homogêneos e, em contrapartida, manter sem previsão expressa a possibilidade de controle judicial sobre a representatividade adequada.

No anteprojeto do Sistema Único Coletivo, com $61 \operatorname{artigos}^{259}$, o objeto das ações por ele reguladas ("ações civis públicas e demais ações coletivas") foi retirado da atual lei da ação civil pública, acrescentado das matérias das demais leis especiais cujas disposições processuais seriam revogadas (Estatuto da Criança e do Adolescente, Estatuto do Idoso, Lei de Proteção das Pessoas Portadoras de Deficiência, Lei de Proteção dos Investidores no Mercado de Valores Mobiliários etc.). $\mathrm{O}$ anteprojeto adota a classificação tripartite dos interesses metaindividuais, definindo os interesses individuais homogêneos como sendo aqueles "decorrentes de origem comum, de fato e de direito, que recomendem tutela conjunta a ser aferida por critérios como facilitação do acesso à Justiça, economia processual, preservação da isonomia processual, segurança jurídica e dificuldade na formação do litisconsórcio" (art. $2^{\circ}$ ); estipula o rito ordinário nos termos do Código de Processo Civil (art. $4^{\circ}$ ); determina a reunião de ações coletivas conexas no juízo prevento (art. $7^{\circ}$, parágrafo $2^{\circ}$ ); impõe a suspensão das ações individuais a partir do ajuizamento de ação coletiva sobre idêntico bem jurídico, salvo comprovação de grave prejuízo (art. $8^{\circ}$,

\footnotetext{
${ }^{258}$ A comissão, criada por meio da Portaria n. 2.481 de 09/12/2008 (DOU de 10/12/2008) para elaboração de anteprojeto de nova lei da ação civil pública, é presidida pelo secretário de Reforma do Judiciário, Rogério Favreto, e relatada pelo professor Luiz Manoel Gomes Júnior, dispondo de sessenta dias para conclusão dos trabalhos, prorrogáveis por igual prazo. A cópia utilizada para a análise é de uma versão preliminar submetida a discussão em workshop promovido pela Escola de Magistrados da Justiça Federal da $3^{\text {a }}$ Região, em 17/11/2008.

${ }^{259}$ A versão obtida, por ser ainda um esboço, contém diversos erros de numeração de artigos.
} 
parágrafo $3^{\circ}$ ); acrescenta ao rol atual de legitimados as mesas das casas do Poder Legislativo, a Defensoria Pública, a OAB, os sindicatos e os partidos políticos (art. $9^{\circ}$ ); veda a intervenção de terceiros no processo coletivo, salvo a assistência litisconsorcial de qualquer legitimado (art. 10); exige a divulgação, pelos meios de comunicação, do ajuizamento de ação para tutela de interesses individuais homogêneos (art. 15); interrompe a prescrição das pretensões individuais e coletivas com a citação na ação coletiva (art. 16); permite a alteração justificada e de boa-fé do pedido, sem anuência do réu, mesmo após a citação, assegurado o contraditório (art. 18); impõe a obrigatoriedade de o juiz comunicar o Ministério Público e outros possíveis legitimados a respeito da existência de processos repetitivos (art. 19); prevê despacho saneador, se inviável a conciliação, incluindo a decisão sobre o prosseguimento da ação como coletiva, a distribuição da responsabilidade pela produção da prova e esclarecimento das partes sobre a distribuição do ônus da prova (art. 21, parágrafo $5^{\circ}$ ); institui preferência pela reconstituição, redução ou compensação do dano provocado a interesse indivisível lesado sobre a indenização (art. $25^{260}$ ); autoriza a sentença genérica na impossibilidade de sentença líquida (art. $27^{261}$ ); prevê a coisa julgada secundum eventum probationis para qualquer ação coletiva, incluindo aquelas em defesa de interesses individuais homogêneos, bem como o transporte in utilibus da coisa julgada coletiva em defesa de interesses difusos e coletivos para ações individuais de indenização (art. $29^{262}$ ); prevê a possibilidade de nova ação coletiva no caso de surgimento de prova nova, incluindo a propositura pelo demandado na ação coletiva inicial (art. $25^{263}$ ); preferência pelo pagamento de indenizações individuais diretamente aos interessados por depósito bancário em conta a ser aberta em instituição oficial (art. 30 264 ); a liquidação pelos danos globalmente sofridos para reversão ao fundo de direitos transindividuais, se não houver a habilitação de interessados em número compatível com o dano (art. $30^{265}$ ); regula a composição e gestão do fundo de direitos metaindividuais (art. 31 a $37^{266}$ ); regula o termo de ajustamento de conduta (art. 38 a $42^{267}$ ) e o cadastro nacional de processos

\footnotetext{
${ }^{260}$ Deveria ser art. 26.

${ }^{261}$ Idem, art. 28.

${ }^{262}$ Idem, art. 30.

${ }^{263}$ Idem, art. 31.

${ }^{264}$ Idem, art. 37.

${ }^{265}$ Idem, art. 38.

${ }^{266}$ Idem, arts. 39 a 44.

${ }^{267}$ Idem, arts. 45 a 49.
} 
coletivos, inquéritos civis e termos de ajustamento de condutas (arts. 43 e $44^{268}$ ). Na parte final, o anteprojeto do Sistema Único Coletivo dispõe sobre a tramitação prioritária das ações coletivas (art. $41^{269}$ ); autoriza a fixação de prêmio ao legitimado constituído na forma de fundação privada, sindicato ou associação cuja atuação na demanda tenha sido relevante, sem especificar a quem cabe fazer o pagamento (art. $44^{270}$ ); determina a instalação de órgãos especializados de primeiro e segundo graus de jurisdição para ações coletivas (art. 49 271 ); impõe a aplicação da lei aos processos trabalhistas, respeitadas suas peculiaridades e princípios informadores (art. $51^{272}$ ); e revoga completamente o sistema processual formado pela Lei da Ação Civil Pública e pelo Código de Defesa do Consumidor, além de outros dispositivos processuais de tutela coletiva em leis especiais $\left(\operatorname{art.} 52^{273}\right)$.

A tendência reformadora da legislação da tutela coletiva mostra-se irrefreável. Há pelo menos dois argumentos muito fortes em favor da opção de reformá-la. Em primeiro lugar, a tutela coletiva, no Brasil, está longe de alcançar o desenvolvimento pretendido quando da edição da Lei n. 7.347/85, e muito longe do que desejam e acreditam ser possível os estudiosos do assunto. Basta verificar a quantidade de demandas coletivas propostas, sentenciadas ou apreciadas em grau recursal ${ }^{274}$. Sob esse ponto de vista, a reforma é necessária.

\footnotetext{
${ }^{268}$ Deveria ser arts. 50 e 51.

${ }^{269}$ Idem, art. 52.

${ }^{270}$ Idem, art. 55.

${ }^{271}$ Idem, art. 57.

272 Idem, art. 59.

${ }^{273}$ Idem, art. 60.

${ }^{274}$ Não obstante a estarrecedora carência de estatísticas, antiga tradição brasileira, é possível inferir, a partir dos poucos dados existentes, que a quantidade de ações é muito pequena, certamente menor do que o necessário para tornar a ação civil pública um efetivo instrumento de acesso à justiça ou mesmo um fator de desafogamento dos órgãos judiciários. Pesquisa elaborada pelo Centro Brasileiro de Estudos e Pesquisas Judiciais (CEBEPEJ), em parceria com a Secretaria de Reforma do Poder Judiciário do Ministério da Justiça (que, com muito esforço, conseguiu reunir pequena fração do universo, já restrito, que pretendia estudar, por ausência de resposta dos órgãos judiciários aos pedidos de informações), revela que, nos cinco anos anteriores a 2007, foram propostas 5.157 ações civis públicas na Justiça Comum do Rio Grande do Sul, tendo sido julgadas 2.237 em primeiro grau de jurisdição e 2.224 em segundo grau, enquanto que, em Mato Grosso, foram ajuizadas 1.225 e julgadas, em primeiro grau, 356; na Justiça Comum de São Paulo, a única informação obtida foi a de que tramitavam, em todo o Estado, em agosto de 2003, 11.054 ações, de um total de 10.810.609, ou seja, 0,1\%; nos cinco anos anteriores a 2007, na Justiça Federal do Rio Grande do Sul, foram propostas 723 ações civis públicas, 0,8\% do total, e julgadas em primeiro grau de jurisdição 762, enquanto na Justiça Federal de Mato Grosso foram ajuizadas 137 ações e sentenciadas 81; na Justiça Federal de São Paulo foram ajuizadas, no mesmo período, 998 ações civis públicas, 0,16\% do total (Relatório Final
} 
Em segundo lugar, passados mais de vinte anos da edição da Lei da Ação Civil Pública, não é descabida a iniciativa de reformulação, considerando ter havido tempo suficiente para verificar, dentro do sistema vigente, quais disposições são eficazes e quais não são. Além disso, num país em que nem mesmo as Constituições Federais vigoram, em média, por tempo maior que esse, vinte anos é tempo suficiente, em pleno século XXI, para a promoção de grandes alterações sociais, exigindo atualizações legislativas. Por esse aspecto, a reforma é tempestiva.

Disso não resulta, necessariamente, que o melhor caminho seja a reforma completa, com revogação integral do sistema vigente. Mas, por outro lado, se o próprio Poder Executivo está receptivo a essa ideia, com perspectiva até mesmo de abrir mão de restrições que antes impôs contra todas as opiniões (entre elas, a limitação das matérias passíveis de tutela coletiva e a restrição territorial da coisa julgada), a oportunidade de uma grande reforma, que institua um sistema lógico e coerente desde os princípios básicos, representa alternativa atraente demais para ser desprezada. A comunidade jurídica não pode esperar, aparentemente, situação mais propícia.

\subsection{2 - Os problemas atuais e as soluções propostas}

Se o momento é de reforma, é ainda mais oportuno abordar alguns dos problemas atuais da tutela coletiva com o fim de propiciar a discussão acerca de instrumentos que possam encaminhar as respectivas soluções. Não é que os problemas antigos estejam resolvidos, bem ao contrário. Algumas das questões mais básicas da tutela coletiva, como a legitimação e a coisa julgada, ainda são alvo de intensa controvérsia, tanto sobre a conveniência quanto sobre a oportunidade de adoção. A exposição, feita no item anterior, a respeito das propostas de reforma da legislação da tutela coletiva, mostra bem que alguns desses temas apresentam poucas, porém importantes diferenças de tratamento,

do Projeto de Pesquisa "Tutela Judicial dos Interesses Metaindividuais - Ações Coletivas", Coordenação Executiva de Leslie Shérida Ferraz, Pesquisador Responsável Marcos Paulo Veríssimo. Brasília: Ideal Gráfica e Editora, 2007, p. 43-54). 
dependendo de quem as formula, como a atribuição de legitimação a pessoas físicas ${ }^{275}$ ou a extensão da coisa julgada coletiva aos interessados ausentes.

Porém, outras questões mais específicas têm causado perplexidade. Uma delas é a das chamadas ações individuais propostas para discussão de interesses originados de causas comuns a grandes coletividades, surgindo, naturalmente, decisões conflitantes a propósito de questões consideradas “incindíveis". É o caso das tarifas de assinatura telefônica, por exemplo. Tais ações, que poderiam ser chamadas de "pseudoindividuais",276, não poderiam ser decididas de maneira individualizada, segundo a doutrina, devendo receber tratamento coletivo.

Os motivos, segundo a doutrina, seriam pelo menos dois: de um lado, haveria impossibilidade de tratamento individual de interesses que seriam, pela sua própria natureza, incindíveis; de outro, o tratamento igualitário decorreria da legislação que regula a prestação do serviço de telefonia, exigindo não apenas a extinção das ações pseudoindividuais e reunião de todas as ações coletivas ${ }^{277}$, como também o litisconsórcio passivo necessário de todas as concessionárias ou a presença do órgão regulador ${ }^{278}$.

Trata-se de sério problema, que tem provocado enorme congestionamento de instâncias judiciárias, até mesmo dos Juizados Especiais, a exemplo dessa questão referente às tarifas de assinatura telefônica. No caso específico, o problema é

\footnotetext{
${ }^{275}$ Quanto a esse aspecto, aparentemente, a divergência reside na oportunidade, não na conveniência. Ou seja, há opiniões no sentido de que a lei não deve conceder legitimação às pessoas físicas, mas boa parte entende que não deve conceder ainda, considerando que nem sequer as associações, até agora, assumiram satisfatoriamente o seu papel, idealizado pelo legislador, de promotoras da tutela coletiva. Nesse sentido, Kazuo Watanabe conjectura: "quem sabe, após a perfeita assimilação pelo povo brasileiro do verdadeiro ideal colimado pelo Código, o que somente ocorrerá com a educação mais aperfeiçoada e mais abrangente, e principalmente com a diminuição do individualismo que nos marca profundamente, estaremos aptos, no futuro, à ampliação total, inclusive a cada indivíduo, da legitimação para agir para a tutela, a título coletivo, dos interesses e direitos dos consumidores" (In: GRINOVER, Ada Pellegrini et al. Código brasileiro de defesa do consumidor comentado pelos autores do anteprojeto. $5^{\mathrm{a}}$ ed. rev. atual. amp. Rio de Janeiro: Forense Universitária, 1998, p. 638).

${ }^{276}$ V. Kazuo Watanabe, Relação entre demanda coletiva e demandas individuais. In: Revista de Processo n. 139, São Paulo, Editora Revista dos Tribunais, set. 2006, p. 32.

${ }^{277}$ Idem, p. 34.

${ }^{278}$ V. Flavio Luiz Yarshell, Brevíssimas reflexões a propósito da legitimidade passiva nas ações civis públicas envolvendo atividades sujeitas a regulação. In: LUCON, Paulo Henrique dos Santos (org.). Tutela coletiva. São Paulo: Atlas, 2006, p.110-113.
} 
agravado pela existência de estímulos à litigiosidade impensáveis, de ordem até mesmo política $^{279}$.

Porém, a solução do problema deve ser buscada de lege ferenda, uma vez inexistirem meios de equacioná-lo com base na legislação vigente ${ }^{280}$. Por mais inconveniente que possa ser a propositura desse número extravagante de ações individuais (ou “pseudoindividuais"), não é cabível a sua extinção, seja por impossibilidade jurídica do pedido, seja por inadequação da via processual eleita. De acordo com as conclusões do item 4.1 retro, não existindo contradição prática nas eventuais sentenças conflitantes que vierem a ser proferidas, de modo que a autoridade seja colocada num verdadeiro dilema, não se trata de interesses incindíveis. De fato, por mais inconveniente, do ponto de vista do Direito Administrativo, no tocante à manutenção do equilíbrio econômico-financeiro nos contratos de concessão de exploração do serviço de telefonia, ou em relação à legislação

\footnotetext{
${ }^{279}$ A pesquisa do CEBEPEJ acima mencionada também analisou, por paradigmática, essa questão. Apurou que, somente contra a TELESP, no início de 2005, havia no Estado de São Paulo 95 mil ações individuais com objeto idêntico às ações coletivas, sendo 52 mil apenas no Juizado Especial Central, quase 10\% de todas as ações em tramitação nos Juizados Especiais de São Paulo. A mesma pesquisa apurou, junto a representante do Poder Judiciário, que advogados faziam intensa propaganda sobre as chances de sucesso nas ações individuais, ainda que tais perspectivas não estivessem sendo correspondidas pelos julgamentos no âmbito dos Juizados Especiais, e que os interessados talvez não confiassem na idoneidade da associação que havia proposto uma ação coletiva; junto a advogados que atuavam na defesa das ações coletivas, a pesquisa apurou também que essa propaganda chegou a ser veiculada na mídia (rádio), como instrumento de verdadeira campanha para obter a extinção da cobrança mediante lei ou ato normativo, até mesmo com o apoio de políticos interessados em aprovar projetos de lei, nesse sentido, de sua autoria (Relatório Final do Projeto de Pesquisa "Tutela Judicial dos Interesses Metaindividuais - Ações Coletivas", Coordenação Executiva de Leslie Shérida Ferraz, Pesquisador Responsável Marcos Paulo Veríssimo. Brasília: Ideal Gráfica e Editora, 2007, p. 74-76).

${ }^{280}$ No julgamento do Conflito de Competência n. 48.177/SP, interposto pela TELESP perante o Superior Tribunal de Justiça, foi decidido, por maioria apertada de votos ( 5 a 4), que a reunião de todas as ações, individuais e coletivas, ou mesmo apenas destas, não era possível por falta de amparo legal, por maior que fosse a conveniência para a Administração da Justiça e para a prevenção da superveniência de decisões conflitantes. Em voto-vista que prevaleceu, o Ministro Teori Albino Zavascki entendeu que "a simples possibilidade de sentenças divergentes sobre a mesma questão jurídica não configura, por si só, conflito de competência. Não existe, em nosso sistema, um instrumento de controle, com eficácia erga omnes, da legitimidade (ou da interpretação), em face da lei, de atos normativos secundários (v.g., resoluçães) ou de cláusulas padronizadas de contratos de adesão. Também não existe, nem mesmo em matéria constitucional, o instrumento da avocação, que permita concentrar o julgamento de múltiplos processos a respeito da mesma questão jurídica perante um mesmo tribunal e, muito menos, perante juiz de primeiro grau. Assim, a possibilidade de decisões divergentes a respeito da interpretação de atos normativos, primários ou secundários, ou a respeito de cláusulas de contrato de adesão, embora indesejável, é evento previsível, cujos efeitos o sistema busca minimizar com os instrumentos da uniformização de jurisprudência (CPC, art. 476), dos embargos de divergência (CPC, art. 546) e da afetação do julgamento a órgão colegiado uniformizador (CPC, art. 555, $\left.\S 1^{\circ}\right)$, dando ensejo, inclusive, à edição de súmulas (CPC, art. 479) e à fixação de precedente destinado a dar tratamento jurídico uniforme aos casos semelhantes. Mas a possibilidade de sentenças com diferente compreensão sobre a mesma tese jurídica não configura, por si só, um conflito de competência" (Relatório Final do Projeto de Pesquisa "Tutela Judicial dos Interesses Metaindividuais - Ações Coletivas", Coordenação Executiva de Leslie Shérida Ferraz, Pesquisador Responsável Marcos Paulo Veríssimo. Brasília: Ideal Gráfica e Editora, 2007, p. 83-84).
} 
concorrencial, tendo em vista a situação de desequilíbrio a que podem ser levadas as empresas prestadoras do serviço na mesma região, no tocante à situação processual não há a possibilidade de conflito prático, ainda que uma das empresas seja obrigada, por ordem judicial, a deixar de cobrar assinatura telefônica de alguns assinantes e manter a cobrança perante outros. Do ponto de vista prático, nada impede que alguns assinantes fiquem isentos desse pagamento e outros não ${ }^{281}$.

Essa constatação de modo algum conduz à defesa da manutenção da situação atual; bem ao contrário, leva a concluir pela urgência de uma alteração legislativa que impeça esse tipo de situação $^{282}$. A solução do problema não pode ser obtida pelos instrumentos atualmente disponíveis, porque não há meios de negar o acesso, ao Poder Judiciário dos interessados que pretendem obter a tutela individual. Ao juiz não é dado extinguir o processo individual se o pedido é juridicamente possível e não é caso de litisconsórcio necessário não formado (que, no caso, nem sequer seria viável praticamente), assim como não pode o juízo coletivizar a demanda, muito menos de ofício.

A solução desse problema passa por dois objetivos (sem considerar a questão da legitimidade passiva dos órgãos reguladores para a ação coletiva, exclusiva ou não), ou seja, a extinção das ações individuais, por demais desejável em matéria tão afeita ao trato coletivo, e a reunião das ações coletivas.

$\mathrm{O}$ atingimento do primeiro objetivo e o primeiro passo para alcançar o segundo poderia ser a conversão de ações individuais em coletivas. Conforme visto no item 4.2.1, no sistema norte-americano o juiz pode converter a demanda coletiva em individual e a individual em coletiva, uma vez que ambas as demandas convivem no mesmo processo ${ }^{283}$. Semelhante possibilidade, como foi visto no item anterior, nem mesmo está sendo discutida nas propostas de reforma, nem sequer uma facilitação dessa conversão

\footnotetext{
${ }^{281}$ Nem de longe a situação se compara, por exemplo, à da anulação de assembleia de acionistas, ou da anulação de casamento ou de testamento, hipóteses em que figuram interesses inegavelmente incindíveis, porque não há como imaginar de que forma tais situações poderiam, do ponto de vista prático, mudar para qualquer um dos interessados sem se alterar, da mesma forma, para todos os outros.

${ }^{282}$ A questão exibe exemplo de situação por demais inconveniente do ponto de vista da prestação do serviço jurisdicional: esses numerosos processos veiculam questões de mérito relativamente simples, mas cujo conhecimento fica obstado por uma infinidade de questões processuais bastante complexas, que simplesmente não existiriam se todos eles fossem reunidos num único processo coletivo, como também lembrado no relatório da pesquisa do CEBEPEJ acima referida.

${ }^{283}$ Nesse sentido, Antonio Gidi, A class action como instrumento de tutela coletiva dos direitos. São Paulo: Editora Revista dos Tribunais, 2007, p. 193.
} 
ou a adesão ao processo coletivo sob a forma de reunião dos autos individuais ao processo coletivo está sendo cogitada. Só o que consta das propostas, como visto, é a comunicação do juiz ao Ministério Público e a outros legitimados sobre a grande incidência da propositura de ações semelhantes ${ }^{284}$. Não parece ser o suficiente para resolver o problema, considerando que a questão das ações pseudoindividuais tem sido amplamente divulgada na imprensa e nem por isso houve a desistência dos processos individuais ou a adesão dos respectivos autores às ações coletivas, ao menos em grande quantidade.

Quanto às ações coletivas, pelo visto, os instrumentos processuais existentes capazes de promover a reunião das ações não têm se mostrado suficientes. As propostas de reforma do sistema processual coletivo estipulam que o juiz prevento deve "determinar a reunião dos processos para julgamento conjunto" "285, bem como a criação de cadastro nacional de processos coletivos ${ }^{286}$, mas não houve a previsão de mecanismos ágeis de comunicação entre os órgãos do Poder Judiciário, bem como um incidente processual igualmente ágil (no tocante à rapidez da sua provocação e à amplitude da sua legitimação) visando a expedição de ordem para reunião dos processos, proferida pelo tribunal competente para julgar os recursos das decisões dos juízos onde tramitam os processos cuja reunião é pretendida.

Outra questão ligada à relação entre demandas coletivas e individuais é a das chamadas ações "pseudocoletivas". Luiz Paulo da Silva Araújo Filho menciona a situação de associações que, representando uma grande quantidade de associados, propõem ação na jurisdição singular para obter sentença específica tutelando o interesse individual de cada um deles, e cita o exemplo de diversas associações que propuseram ações em prol de seus associados para a recuperação de expurgos na correção monetária das contas do Fundo de Garantia do Tempo de Serviço, por exemplo ${ }^{287}$.

Entende o autor que essa prática tem permitido "a usurpação de direitos individuais e a distorção dos propósitos constitucionais", levando à "vedação do exercício

\footnotetext{
${ }^{284}$ Art. $8^{\circ}$ do anteprojeto da USP; art. 10 do anteprojeto da UERJ/Unesa; art. 19 do anteprojeto do Ministério da Justiça.

${ }^{285}$ Art. $6^{\circ}$, parágrafo $2^{\circ}$, do anteprojeto da USP; art. 6 do anteprojeto da UERJ/Unesa; art. $7^{\circ}$, parágrafo $2^{\circ}$, do anteprojeto do Ministério da Justiça.

${ }^{286}$ Art. 46 do anteprojeto da USP; art. 43 (ou 50) do anteprojeto do Ministério da Justiça.

${ }^{287}$ Ações coletivas: a tutela jurisdicional dos direitos individuais homogêneos. Rio de Janeiro: Forense, 2000, p. 199-202.
} 
do direito subjetivo pelo próprio titular do direito" ${ }^{288}$. Sustenta que o problema decorrente da multiplicidade de situações individuais convivendo na mesma relação jurídicoprocessual, conduzindo, muitas vezes, ao comprometimento do direito ao contraditório e à prestação jurisdicional, não pode ser resolvido facilmente. Com efeito, não há amparo legal para a prolação de sentença genérica, por não se tratar de ação coletiva, nem de determinação para o autor emendar a petição inicial para formular pedido genérico, por não se tratar de defeito ou irregularidade, nem de limitar o número de substituídos por aplicação analógica da vedação ao litisconsórcio multitudinário ${ }^{289}$. Ficariam sem solução graves problemas só previstos na legislação para as verdadeiras ações coletivas, como a litispendência entre a ação "pseudocoletiva" e as eventuais ações individuais e a sujeição à coisa julgada formada na falsa ação coletiva pelos representados.

Em primeiro lugar, convém separar os problemas específicos da tutela coletiva, presentes na hipótese, dos reflexos de outras questões processuais, como a legitimação das associações para a defesa dos interesses de seus associados, até mesmo para executar o julgado e dar quitação. A atribuição de poderes às associações para representar seus associados representou verdadeiro corolário da garantia constitucional da liberdade de associação, uma das formas de liberdade de expressão coletivas garantidas pela Constituição Federal ${ }^{290}$. Portanto, a possibilidade de representação judicial dos associados constitui uma conquista social ${ }^{291}$, ainda que, como outras garantias constitucionais, possa ser utilizada abusivamente, o que gera distorções, assim como acontece até mesmo com a própria garantia do acesso à justiça ${ }^{292}$.

Em decorrência da autorização constitucional, as associações podem postular interesses individuais homogêneos de seus associados, desde que autorizados expressamente $^{293}$. Essa autorização, válida para todos os associados, pode estar contida na

\footnotetext{
${ }^{288}$ Idem, p. 199 e 202.

${ }^{289}$ Art. 46, parágrafo único, do Código de Processo Civil.

290 A propósito, v. José Afonso da Silva, Curso de direito constitucional positivo. $19^{\mathrm{a}}$ ed. rev. atual. São Paulo: Malheiros, 2001, p. 237-238 e 269-271.

291 O art. 5', inciso XXI, da Constituição Federal dispõe que "as entidades associativas, quando expressamente autorizadas, têm legitimidade para representar seus filiados judicial ou extrajudicialmente".

${ }^{292}$ V. item 2.2 deste trabalho, sobre os estímulos à litigiosidade.

${ }^{293}$ A doutrina diverge sobre se a Constituição criou nova espécie de representação, mais facilitada, pois a autorização não precisaria ser individualizada e específica, como no mandato comum, ou se previu nova hipótese de legitimação extraordinária, por meio da qual a associação litigaria em nome próprio em defesa de direito alheio, dos seus associados. Entendem tratar-se de representação processual, entre outros, Athos
} 
lei, nos próprios estatutos associativos ou em decisão assemblear específica ${ }^{294}$. Sendo exigível alguma forma de autorização, os associados sabem da possibilidade de a associação ajuizar ação em seu benefício, não podendo alegar desconhecimento seja da previsão legal, seja da previsão de autorização para a defesa judicial de matérias ligadas ao seu objeto associativo, no estatuto ao qual aderiram, seja ainda de deliberação da assembleia dos associados para esse fim. Assim como o associado teve toda a liberdade de ingressar na entidade, pode também dela pleitear exclusão se não desejar mais que ela faça a defesa judicial de seus interesses.

Portanto, a possibilidade de um associado vir a ter o seu interesse tutelado por associação da qual faça parte sem ter manifestado aquiescência específica, assim como de a entidade vir a executar eventual sentença favorável, por si só, não são problemas sem solução.

A dificuldade maior está na presença, no polo passivo de ação condenatória, visando sentença certa e determinada, de interesses de grande número de associados. Trata-se, naturalmente, de situação assemelhada à da ação coletiva, sem o regramento correspondente, a assegurar a ausência de litispendência e a afastar a sujeição da coisa julgada, como apontado pela doutrina.

De qualquer maneira, se a demanda não envolver, na prática, a discussão de questões individuais que comprometam o núcleo de homogeneidade dos interesses dos associados, não é vedado ao juiz proferir sentença líquida e remeter as partes (nesse momento, os próprios interessados, não mais a associação, se necessário divididos em grupos mais homogêneos), para a liquidação e execução do julgado ${ }^{295}$.

Gusmão Carneiro (O mandado de segurança coletivo como garantia dos cidadãos. In: TEIXEIRA, Sálvio de Figueiredo (org.). As garantias do cidadão na justiça. São Paulo: Saraiva, 1993, p. 227) e Uadi Lammêgo Bulos (Constituição federal anotada. $7^{\text {a }}$ ed. rev. atual. São Paulo: Saraiva, 2007, p. 187); entende ser caso de legitimação extraordinária, entre outros, José Carlos Barbosa Moreira (Ações coletivas na constituição federal de 1988. In: Revista de Processo n. 61, São Paulo, Editora Revista dos Tribunais, jan./mar. 1991, p. 190).

${ }^{294}$ Nesse sentido, v. RE n. 141.733-1/SP e AO n. 152-8/RS.

${ }^{295}$ Luis Paulo da Silva Araújo Filho entende que o juiz não pode lançar sentença genérica (Ações coletivas: $a$ tutela jurisdicional dos direitos individuais homogêneos. Rio de Janeiro: Forense, 2000, p. 202). Não parece que seja assim, entretanto; o juiz tem o dever de proferir a sentença o mais líquida possível, mas pode deixar de fazê-lo, se impossível (v. item 3.3). A liquidação de sentença não foi revogada do sistema (art. 475-A e seguintes do Código de Processo Civil), cabendo não apenas a sentença genérica como a sentença específica mediante indenização uniforme ou fórmula matemática, exatamente as hipóteses que os anteprojetos de tutela coletiva desejam prever expressamente para aquela seara (v. item 4.4.1). A trabalhosa apuração de inúmeros 
Resta, assim, a equiparação completa da ação por parte de associações em defesa de seus associados às ações coletivas, para fins de regulação da litispendência entre ações individuais e a ação "pseudocoletiva" e dos efeitos subjetivos da coisa julgada. Tratando-se de ação por tudo equiparada a uma ação coletiva, convinha a equiparação, legalmente expressa. Todavia, não há qualquer previsão nas propostas de anteprojeto, conforme visto.

Uma última questão a ser abordada é a viabilidade da tutela coletiva nos Juizados Especiais, de lege ferenda. A regulamentação de ações coletivas e a instituição de uma jurisdição marcada por uma maior informalidade são as duas iniciativas mais promissoras que têm sido desenvolvidas para fazer frente aos desafios de garantir o pleno acesso à justiça. Porém, em princípio, o Juizado Especial foi idealizado para causas mais simples, em que predomina a disponibilidade dos interesses em jogo, de modo a permitir o exercício constante da conciliação e da transação, enquanto a tutela coletiva é predisposta à defesa de interesses coletivamente considerados, ainda que apresentem maior complexidade fática ou jurídica e mesmo sem qualquer margem de disposição pela partes. Essas características levam a crer que as duas iniciativas são inconciliáveis, uma vez que não pode haver, à primeira vista, demanda que envolva, ao mesmo tempo, matéria simples e complexa, direitos disponíveis e indisponíveis, interesses individuais e coletivos. Por essa razão, ao criar os Juizados Especiais Federais, o legislador estipulou no art. $3^{\circ}$, parágrafo $1^{\circ}$, inciso I, da Lei n. 10.259/2001 que "não se incluem na competência do Juizado Especial Cível as causas (...) sobre direitos ou interesses difusos, coletivos ou individuais homogêneos". Na esfera estadual, constituem mecanismos de restrição indireta à propositura de ações coletivas a limitação do valor da causa e a ilegitimidade passiva das pessoas jurídicas de direito público interno (art. $3^{\circ}$, inciso I, e art. $8^{\circ}$ da Lei n. 9.099/90).

danos individuais que depois poderão se revelar inteiramente inúteis, em caso de sentença de improcedência do pedido de condenação na obrigação de indenizar, constitui violação frontal do princípio da economia processual, nada impedindo a aplicação analógica do art. 95 do Código de Processo Civil nesses casos.

Ademais, o princípio da correlação entre pedido e sentença constitui garantia do autor, não sendo razoável aplicá-lo em seu prejuízo, como ocorreria se o processo de conhecimento acabasse inviabilizado diante de inúmeras liquidações de danos. Nesse sentido, aludindo também a jurisprudência do Superior Tribunal de Justiça, v. Cândido Rangel Dinamarco, Instituições de direito processual civil - vol. III. $4^{\mathrm{a}}$ ed. rev. atual. São Paulo: Malheiros, 2004, p. 278. Por fim, a obrigação decorrente de ato ou fato ilícito constitui a hipótese mais comum de autorização de pedido genérico (e, conseqüentemente, de sentença genérica), nos termos do art. 286, inciso II, do Código de Processo Civil. 
A natureza dos interesses individuais homogêneos tem demonstrado ser falsa essa impressão ${ }^{296}$. A se considerar a natureza bifronte dos interesses individuais homogêneos, essencialmente individuais, mas tratáveis coletivamente em razão da homogeneidade que lhes confere uma dimensão coletiva, a maior parte deles de natureza patrimonial, portanto disponível, e frequentemente envolvendo matéria jurídica de baixa complexidade, às vezes dispensando mesmo qualquer discussão fática, a possibilidade de processá-los no rito dos Juizados Especiais se apresenta como mais do que adequada: pode ser indispensável para preservar as finalidades de um e de outro.

O exemplo citado acima, das assinaturas telefônicas, é apenas um dos muitos que têm frequentado o noticiário, como o das ações buscando recomposição de aposentadorias e pensões, devolução de ativos bloqueados, correção monetária de saldos de aplicações financeiras, reajuste de mensalidades de planos de saúde, entre muitos outros. Essas ações serão ajuizadas em grandes quantidades nos Juizados Especiais, se isso for possível (e a maioria pode ser ajuizada, pelo baixo valor), a despeito das ações coletivas que possam estar sendo ajuizadas na jurisdição comum. Os atrativos do juizado são muitos, destacando-se a celeridade, que já vai ficando comprometida com o acúmulo dessas ações repetidas.

No desenho idealizado nas reformas do processo civil, as ações repetidas deveriam ser direcionadas para a jurisdição coletiva, cabendo aos Juizados Especiais as causas não repetitivas de baixo valor, presumivelmente mais simples (embora nem sempre). Ocorre que não é isso que está acontecendo. Atraídos pela celeridade do rito sumaríssimo (entre outras vantagens, como a dispensa de advogado) e pelas dificuldades do processo coletivo, mais moroso do que os demais processos da jurisdição comum, ${ }^{297}$ os jurisdicionados têm acorrido aos Juizados Especiais para todas as demandas que lá podem ser ajuizadas. O resultado tem sido o acúmulo de processos e o início de um processo de deterioração da qualidade do serviço jurisdicional também nesses órgãos ${ }^{298}$.

\footnotetext{
${ }^{296}$ V. item 1.5.

${ }^{297}$ V. item 2.4.2.

${ }^{298}$ Kazuo Watanabe, há quase dez anos, escreveu que "é imperioso que se impeça que os juizados especiais sejam vistos e utilizados como panacéia geral, para eles canalizando a grande maioria das demandas cíveis, pois isto representará, fatalmente, a falência de todo o sistema. O microssistema deve ser mantido sempre ágil, célere, informal, eficiente e perfeitamente capacitado" (Finalidade maior dos juizados especiais cíveis. In: Cidadania e Justiça, ano 3, n. 7, Rio de Janeiro, $2^{\circ}$ semestre de 1999, p. 37).
} 
Por essa razão, enquanto o processo coletivo não atinge o grau de difusão que todos os estudiosos do assunto acreditam que ele deve ter, a abertura dos Juizados Especiais à tutela coletiva é uma necessidade para preservação das suas próprias finalidades ${ }^{299}$. Entretanto, tampouco essa matéria foi tratada em qualquer das proposições analisadas no item anterior, como visto.

${ }^{299}$ No mesmo sentido, em relação aos Juizados Especiais Federais especificamente, Antonio de Souza Prudente (A tutela coletiva e de evidência no Juizado Especial Federal Cível e o acesso pleno à justiça. In:

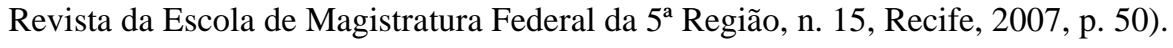




\title{
CAPÍTULO 5 - AS INCERTEZAS NA TUTELA JURISDICIONAL DOS INTERESSES INDIVIDUAIS HOMOGÊNEOS
}

\begin{abstract}
5.1 - A legitimação para agir; 5.1.1 - Aspectos polêmicos; 5.1.2 Estudo de caso: indisponibilidade e legitimação do Ministério Público; 5.2 - O pedido e a sentença; 5.2.1 - Aspectos polêmicos; 5.2.2 - Estudo de caso: o controle de constitucionalidade e a tutela coletiva; 5.3 - A coisa julgada; 5.3.1 - Aspectos polêmicos; 5.3.2 Estudo de caso: coisa julgada e tutela coletiva; 5.4 - A execução; 5.4.1 - Aspectos polêmicos; 5.4.2 - Estudo de caso: a liquidação da sentença coletiva.
\end{abstract}

\section{1 - A legitimação para agir}

\subsection{1 - Aspectos polêmicos}

A legitimação na tutela coletiva de interesses individuais homogêneos já foi tratada em termos gerais, neste trabalho ${ }^{300}$. Cumpre agora aprofundar a análise apresentando os principais aspectos cercados de dúvidas nessa matéria, em torno dos quais os especialistas têm divergido.

O primeiro deles é a natureza da legitimação na tutela coletiva. A legitimação para agir em juízo, ou legitimidade ${ }^{301}$, pode ser classificada com base no critério da coincidência entre a titularidade do direito e a autorização legal para defendê-lo em juízo. Com base nesse critério, a legitimidade seria ordinária, se houvesse coincidência, e extraordinária, se não houvesse.

Existe outro critério, porém, só aplicável para distinguir as hipóteses de legitimidade extraordinária, consistente na obrigatoriedade da presença do titular do direito (o que seria legitimado ordinário): se fosse dispensável a presença da pessoa que ordinariamente seria a legitimada, a legitimidade extraordinária seria autônoma; sendo obrigatória essa presença, de modo que o legitimado extraordinário só pudesse atuar em juízo ao lado do legitimado ordinário, a legitimidade extraordinária seria subordinada ${ }^{302}$.

\footnotetext{
${ }^{300}$ V. item 4.3.1.

${ }^{301}$ V. Vicente Greco Filho, Direito processual civil brasileiro - $1^{\text {o }}$ vol. $9^{\mathrm{a}}$ ed. São Paulo: Saraiva, 1994, p. 77.

${ }^{302}$ Mencionando doutrina de José Carlos Barbosa Moreira, v. Cândido Rangel Dinamarco, Instituiçõoes de direito processual civil - vol. II. $4^{\text {a }}$ ed. rev. atual. São Paulo: Malheiros, 2004, p. 313.
} 
No caso dos interesses individuais homogêneos, a legitimidade está restrita, no direito posto, ao Ministério Público, aos órgãos da administração pública e às associações, como visto anteriormente. Nesse caso, o autor coletivo age em juízo em nome próprio na defesa dos interesses de uma coletividade de pessoas; como regra, ele não é um dos interessados. Portanto, sua legitimidade seria extraordinária. Como exceção, pode também litigar por direito próprio e alheio, como na hipótese em que associação de defesa de consumidores é também consumidora de determinado produto e propõe ação coletiva para pleitear indenização, em face do fornecedor, por dano provocado a todos os consumidores. Todavia, também nesse caso a legitimidade poderia ser considerada extraordinária, pois não se trata de ação individual, mas coletiva, e o interesse coletivo, não há dúvida, não pertence à associação, senão à coletividade formada pelos consumidores lesados.

Mas há autores que entendem existir uma legitimação ordinária das associações para a defesa de interesses transindividuais incluídos entre seus objetivos institucionais $^{303}$. Isso porque, se a associação tem entre seus objetivos a proteção de determinado interesse, ao defendê-lo em juízo o estaria fazendo não apenas em nome próprio, mas em defesa de interesse próprio. No entanto, essa tese seria aplicável mais facilmente à tutela de interesses difusos e coletivos em sentido estrito e ainda assim cairíamos na mesma hipótese acima mencionada da associação de defesa de consumidores também consumidora de determinado produto que enseja o ajuizamento de ação coletiva: ela é interessada, mas o seu interesse não corresponde ao interesse coletivo que ela vai defender em juízo e isso basta para, com base no critério da coincidência entre titular do interesse e autorização legal para defendê-lo em juízo, considerar sua legitimidade extraordinária $^{304}$.

\footnotetext{
${ }^{303}$ V. Pedro Lenza (Teoria geral da ação civil pública. São Paulo: Editora Revista dos Tribunais, 2003, p. 182-183), citando Vicenzo Vigoriti (que a denomina "legittimazione ordinaria sui generis"), José Carlos Barbosa Moreira e Kazuo Watanabe.

${ }^{304}$ Nesse sentido, Teori Albino Zavascki (Processo Coletivo - Tutela de direitos coletivos e tutela coletiva de direitos. $2^{\mathrm{a}}$ ed. rev. atual. São Paulo: Editora Revista dos Tribunais, 2007, p. 168), Pedro Lenza (Teoria geral da ação civil pública. São Paulo: Editora Revista dos Tribunais, 2003, p. 185); Ada Pellegrini Grinover (Código brasileiro de defesa do consumidor comentado pelos autores do anteprojeto. $5^{\mathrm{a}}$ ed. rev. atual. amp. Rio de Janeiro: Forense Universitária, 1998, p. 674); Nelson Nery Júnior e Rosa Maria Andrade Nery (Código de processo civil comentado e legislação extravagante. $4^{\mathrm{a}}$ ed. rev. amp. São Paulo: Editora Revista dos Tribunais, 1999).
} 
Seja como for, a questão perde relevância por duas razões. Em primeiro lugar porque, como leciona Rodolfo de Camargo Mancuso, "o critério legitimante, em tema de interesses metaindividuais, não repousa na titularidade, e sim na idoneidade social de seu portador ${ }^{305}$, de modo que procurar classificar a legitimação na tutela coletiva com base na titularidade do direito não faz mesmo muito sentido. Precisamente por isso há autores sustentando que, na tutela coletiva, a legitimação ordinária (no sentido de normal, comum) é a extraordinária ${ }^{306}$. Em segundo lugar porque, seja qual for a espécie de legitimação, as consequências jurídicas serão as mesmas, ou seja, qualquer dos legitimados poderá propor a ação independentemente dos demais (e sem a companhia dos próprios interessados, como regra quase absoluta), a desistência ou abandono injustificados ensejará a assunção da autoria pelo Ministério Público, a execução coletiva poderá ser promovida pelo mesmo autor coletivo da fase de conhecimento ou por outro dos legitimados etc.

Outra questão mais difícil e discutida em sede de tutela jurisdicional de interesses individuais homogêneos é a legitimidade do Ministério Público. Nessa matéria, há três correntes: uma defendendo a ilegitimidade, outra a legitimidade irrestrita e a terceira, a legitimidade restrita ${ }^{307}$.

O fundamento da tese da ilegitimidade é a ausência de atribuição constitucional de legitimidade para o Ministério Público fazer a defesa desse tipo de interesse, uma vez que o art. 129, inciso III, da Constituição Federal estipula, dentre as funções institucionais do Ministério Público, a promoção do inquérito civil e da ação civil pública, para a proteção do patrimônio público e social, do meio ambiente "e de outros interesses difusos e coletivos". Ao não mencionar os interesses individuais homogêneos, o legislador constitucional teria vedado a promoção da defesa desses interesses pelo

\footnotetext{
${ }^{305}$ Ação civil pública. $5^{\text {a }}$ ed. rev. atual. amp. São Paulo: Editora Revista dos Tribunais, 1997, p. 79.

${ }^{306}$ Embora tratando mais especificamente dos interesses difusos e coletivos em sentido estrito, v. Teori Albino Zavascki (Processo Coletivo - Tutela de direitos coletivos e tutela coletiva de direitos. $2^{\mathrm{a}}$ ed. rev. atual. São Paulo: Editora Revista dos Tribunais, 2007, 78). Também Pedro Lenza sustenta que "a legitimação extraordinária deve ser a regra da tutela jurisdicional na sociedade de massa, devendo ser dada preferência à 'molecularização dos conflitos"' (Teoria geral da ação civil pública. São Paulo: Editora Revista dos Tribunais, 2003, p. 185).

307 V. José Marcelo Menezes Vigliar, que apresenta quatro posições quanto à legitimação do Ministério Público para a ação civil pública, mas apenas três delas diferenciadas quanto aos interesses individuais homogêneos (Tutela jurisdicional coletiva. $3^{\text {a }}$ ed. São Paulo: Atlas, 2001, p. 149-152).
} 
parquet $^{308}$. As críticas feitas a esse posicionamento são as de que decorre de interpretação gramatical e literal da Constituição Federal. A ausência do conceito "interesses individuais homogêneos", sustenta-se, explica-se não pela intenção do constituinte de excluí-la da área de atuação do Ministério Público, mas porque essa expressão ainda não havia sido incorporada ao ordenamento jurídico, pois sequer na legislação ordinária registrava-se a sua utilização ${ }^{309}$.

Para os defensores da legitimidade irrestrita, o Ministério Público pode agir sempre que o fizer na defesa de interesses sociais ou individuais indisponíveis, uma vez que recebeu essa incumbência por norma constitucional expressa, nos termos do art. 129, inciso IX ("são funções institucionais do Ministério Público (...) exercer outras funções que lhe forem conferidas, desde que compativeis com sua finalidade"), combinando com art. 127 (“o Ministério Público é instituição permanente, essencial à função jurisdicional do Estado, incumbindo-lhe a defesa da ordem jurídica, do regime democrático e dos interesses sociais e individuais indisponíveis").

Como os interesses transindividuais, incluindo os individuais homogêneos, possuem presunção legal de relevância social, então o Ministério Público possui ampla legitimidade para a sua defesa ${ }^{310}$. Para os críticos, como Hugo Nigro Mazzilli, "essa posição não leva em plena conta que o legislador ordinário só pode cometer ao Ministério Público atribuições compatíveis com seu perfil constitucional"311. Teori Albino Zavascki cita julgados do Supremo Tribunal Federal (RE n. 195.056-1, Relator Min. Carlos Velloso, DJ de 14/11/2003, p. 18, e o RE n. 163.231-3, Relator Min. Maurício Correa, DJ de 29/06/2001) entendendo que somente a lei pode definir quais

\footnotetext{
${ }^{308}$ Nesse sentido, v. Ives Gandra da Silva Martins, Ação civil pública para defesa de direitos individuais. In: WALD, Arnoldo. Aspectos polêmicos da ação civil pública. São Paulo: Saraiva, 2003, p. 209.

${ }^{309}$ Ainda que já houvesse previsão de ações para tutela de interesses individuais homogêneos, como visto no item 4.2.2, porém sem a adoção dessa denominação.

${ }^{310}$ Nesse sentido, v. Ada Pellegrini Grinover (Código brasileiro de defesa do consumidor comentado pelos autores do anteprojeto. $5^{\text {a }}$ ed. rev. atual. amp. Rio de Janeiro: Forense Universitária, 1998, p. 678), embora ressalve a possibilidade de aferição, no caso concreto, da relevância social. V. também Nelson Nery Júnior e Rosa Maria Andrade Nery (Código de processo civil comentado e legislação extravagante. $7^{\mathrm{a}}$ ed. rev. amp. São Paulo: Editora Revista dos Tribunais, 2003, p. 1866), ressaltando que "o cerne da questão é que a ação coletiva, em suas três modalidades, é de interesse social".

${ }^{311}$ A defesa dos interesses difusos em juízo. $15^{\mathrm{a}}$ ed. rev. amp. atual. São Paulo: Saraiva, 2002, p. 87.
} 
seriam os interesses socialmente relevantes para fins de atribuição de legitimidade para o Ministério Público, como fez a Lei n. 8.078/90 com o interesse dos consumidores ${ }^{312}$.

Assim, resulta que a terceira posição, ou seja, a tese da legitimidade restrita, desenvolve-se a partir da comparação entre a destinação institucional da atuação do Ministério Público e a relevância social da defesa dos interesses individuais homogêneos de que se trata. Se esse interesse revelar importância social compatível com as incumbências constitucionais do parquet, este possuirá legitimidade para a sua defesa, caso contrário, não. Kazuo Watanabe defende que "somente a relevância social do bem jurídico tutelando ou da própria tutela coletiva poderá justificar a legitimação do Ministério Público para a propositura de ação coletiva em defesa de interesses privados disponíveis" ${ }^{313}$.

Essa posição parece ser a majoritária, mas as divergências concentram-se na formulação de critérios para averiguar a relevância social capaz de justificar a iniciativa do Ministério Público na defesa de interesses individuais homogêneos. Rodolfo de Camargo Mancuso sugere duas verificações, ou seja, "se sua homogeneidade deriva de 'origem comum' (CDC, art. 81, III)" e “se, ademais, apresenta a nota da 'indisponibilidade' (CF, art. 127, parte final) ${ }^{, 314}$. Hugo de Brito Machado entende que o critério deve ser a presença de duas características dos interesses em questão, isto é, "sejam, em sua globalidade, de grande expressão coletiva" e "em suas quotas, ou parcelas, individualizadas, ou individualizáveis, sejam de valor econômico não significativo $^{315}$.

Hugo Nigro Mazzilli sugere outros três critérios, quais sejam "a natureza do dano (saúde, segurança e educação públicas)", "conforme a dispersão dos lesados (a abrangência social do dano, sob o aspecto dos sujeitos atingidos)" e "o interesse social no funcionamento de um sistema econômico, social ou jurídico (previdência social, captação

\footnotetext{
${ }^{312}$ Processo Coletivo - Tutela de direitos coletivos e tutela coletiva de direitos. $2^{\mathrm{a}}$ ed. rev. atual. São Paulo: Editora Revista dos Tribunais, 2007, p. 236-237.

${ }^{313}$ In: GRINOVER, Ada Pellegrini et al. Código brasileiro de defesa do consumidor comentado pelos autores do anteprojeto. $5^{\text {a }}$ ed. rev. atual. amp. Rio de Janeiro: Forense Universitária, 1998, p. 640-642.

${ }^{314}$ Sobre a legitimação do Ministério Público em matéria de interesses individuais homogêneos. In: MILARÉ, Edis. Ação civil pública (Lei 7.347/85 - Reminiscências e reflexões após dez anos de aplicação). São Paulo: Editora Revista dos Tribunais, 1995, p. 445.

315 O Ministério Público e os direitos individuais homogêneos. In: Repertório IOB de Jurisprudência, vol. III, n. 18, São Paulo, $2^{\mathrm{a}}$ quinzena de set. 1996, p. 323.
} 
de poupança, questões tributárias etc.)". Tais critérios são os que deram origem à Súmula n. 7 da Câmara Superior do Ministério Público de São Paulo ${ }^{316}$.

Não há dúvida de que a tese da ilegitimidade é excessivamente restritiva, pelos motivos já apontados. Por outro lado, as posições da legitimidade e ilegitimidade assemelham-se, pelo menos, ao admitir que a presença de interesse social é indispensável para legitimar a atuação do Ministério Público. Mas não há um critério comum para aferir, em síntese, quando, em tema de tutela de interesses individuais homogêneos, está presente o interesse público e quando não está.

Cada um dos critérios apontados procura indicar uma hipótese de presença inegável de interesse público, mas nenhuma parece esgotar as possibilidades. Ocorre que o próprio cabimento da tutela coletiva já exige a relevância social dos interesses individuais homogêneos ${ }^{317}$. Quaisquer interesses individuais homogêneos, para serem tuteláveis coletivamente, devem apresentar relevância social. Prova disso é que, ninguém discute, o Ministério Público tem legitimidade, em qualquer ação em defesa de interesses individuais homogêneos, para intervir como fiscal da lei, caso não seja parte ${ }^{318}$. Como encontrar então o limite à atuação ministerial?

A resposta está na lei. Não basta o interesse ser considerado relevante, é preciso que a lei assim o considere para que o Ministério Público tenha legitimidade para a sua tutela jurisdicional. Antônio Cláudio Costa Machado, referindo-se à hipótese legal de intervenção do Ministério Público referente a "interesse público", mas que também se aplica ao preceito constitucional dos "interesses sociais e individuais indisponíveis", explica que "o interesse público a que alude o inc. III do art. 82 não é algo que corresponda a um ideal ou valor; pelo contrário, é algo concreto, interesse tornado direito por norma jurídica, interesse verificável objetiva e subjetivamente perante o direito. A só

\footnotetext{
${ }^{316}$ A Súmula n. 7 foi revista em 09/12/2003, alterando-se parcialmente a sua redação. A primeira hipótese, que antes incluía os interesses relativos à saúde, segurança e acesso à educação, passou a incluir os direitos e garantias constitucionais e os socialmente relevantes; a segunda hipótese, de interesses lesados cujos titulares estejam dispersos, praticamente não foi alterada; a terceira, não mais se refere a "funcionamento de um sistema econômico, social ou jurídico", mas à "implementação efetiva e o pleno funcionamento da ordem jurídica, nas suas perspectivas econômica, social e tributária" (v. Marco Antonio Zanellato, A defesa dos interesses individuais homogêneos dos consumidores pelo Ministério Público. In: Revista do Advogado n. 89, São Paulo, dez. 2006, p. 104).

${ }^{317} \mathrm{~V}$. item 3.4.2.

${ }^{318}$ Art. $5^{\circ}$, parágrafo $1^{\circ}$, da Lei n. 7.347/85 e art. 92 da Lei n. 8.078/90.
} 
relevância social ou política de um interesse não o torna direito, muito menos indisponível"319.

As formas pelas quais a lei estipula a relevância social de determinados interesses são três, a saber, a imposição da indisponibilidade, a atribuição direta de legitimidade ao Ministério Público para sua defesa e a caracterização expressa de relevância social. Na presença de qualquer deles, está o parquet autorizado a defendê-lo em juízo ${ }^{320}$.

Todo interesse social é indisponível, pela sua própria natureza. Mas também todo interesse tornado indisponível passa a ser socialmente relevante, porque a própria indisponibilização feita pela lei constitui indicador seguro dessa relevância.

A indisponibilidade constitui mecanismo de proteção jurídica de interesses especialmente defendidos pela legislação. Se os interesses disponíveis podem ser violados por atos defeituosos, para cuja correção pode ser necessária a prova da sua ocorrência em juízo, como é o caso do erro, do dolo e da lesão, os interesses indisponíveis encontram-se mais protegidos justamente porque sua disposição induz nulidade absoluta dos atos praticados com essa finalidade, ainda que pelos seus próprios titulares e mesmo diante de regular representação jurídica. Tais atos, portanto, são muito mais facilmente desconstituíveis.

Hugo Nigro Mazzilli explica que, ao lado do interesse social, as duas causas que podem trazer o Ministério Público ao processo são a indisponibilidade de interesse ligado a uma pessoa ou a indisponibilidade ligada a uma relação jurídica, podendo ser total ou parcial, como ocorre na "guarda de filhos, alimentos, investigação de paternidade etc." 321 . O autor arremata dizendo que "num sentido mais amplo, portanto, até

\footnotetext{
${ }^{319}$ A intervenção do Ministério Público no processo civil brasileiro. $2^{\mathrm{a}}$ ed. rev. atual. São Paulo: Saraiva, 1998, p. 339.

${ }^{320}$ Pedro da Silva Dinamarco menciona entendimento do Supremo Tribunal Federal no sentido de que o legislador só pode atribuir funções ao Ministério Público se considerá-las indispensáveis à defesa da ordem jurídica, do regime democrático e dos interesses sociais e individuais indisponíveis (RE n. 213.631-0/MG, Pleno, Relator Min. Ilmar Galvão, decisão de 09/12/99). Seja como for, confirma-se que a escolha é do legislador e o seu questionamento só cabe em sede de controle de constitucionalidade da lei. O mesmo autor relata também que o tribunal, em outro julgamento (RE n.195.056-1/PR, Relator Min. Carlos Velloso, decisão de 09/12/99), considerou que os direitos do consumidor são indisponíveis e os do contribuinte não são (Ação civil pública. São Paulo: Saraiva, 2001, p. 215-216).

${ }^{321}$ V. A defesa dos interesses difusos em juízo. $15^{\mathrm{a}}$ ed. rev. amp. atual. São Paulo: Saraiva, 2002, p. 72.
} 
o interesse individual, se indisponível, será interesse público, e seu zelo caberá ao Ministério Público" ${ }^{, 322}$.

Assim, pode-se dizer que se o legislador tornou indisponível determinado interesse, o fez porque o considerava socialmente relevante ${ }^{323}$. Se é assim, a enumeração do art. 127 da Constituição Federal, ao colocar os interesses individuais indisponíveis ao lado dos interesses sociais só pode ser interpretada como uma inequívoca exclusão dos interesses individuais disponíveis dentre as incumbências do Ministério Público, não a evidenciação de que os interesses indisponíveis não sejam, também eles, interesses sociais.

O outro indicador da relevância social dos interesses jurídicos é a própria atribuição legal de legitimidade ao Ministério Público para a sua defesa, como ocorre com as Leis n. 6.024/74, n. 7.913/89 e, naturalmente, n. 8.078/90 ${ }^{324}$. Nesses casos, é a relevância social que justifica a atribuição de legitimidade, mas a questão nem se coloca, porque o legislador já autorizou a iniciativa ministerial direta e expressamente.

Muitas vezes, essa atribuição de legitimidade vem acompanhada da enunciação de que o interesse tratado no diploma legal deve ser considerado como sendo de interesse social, como acontece no Código de Defesa do Consumidor ${ }^{325}$. Mas ainda que não o faça, está o Ministério Público autorizado a defendê-lo em juízo. Constitui, portanto, outra forma, indireta, de legitimação do órgão ministerial.

Fora desses casos, expressamente previstos em lei, de indisponibilidade dos interesses ou de atribuição expressa de legitimidade, não há legitimação para agir do Ministério Público na tutela de interesses individuais homogêneos.

\footnotetext{
${ }^{322}$ Idem, p. 73.

323 Antonio Cláudio Costa Machado explica que "o legislador distingue duas categorias de interesses juridicizados ou direitos subjetivos. De um lado, os direitos que devam servir, atender diretamente àqueles valores; direitos que correspondem imediatamente a esses interesses maiores e que se identificam com o escopo último da ordem pública, a preservação do próprio Estado. De outro lado, aqueles direitos periféricos aos valores fundamentais que só indireta e mediatamente servem à ordem pública, embora também nela encontrem balizamento.Aos primeiros, pela sua importância, pela maior necessidade de prevalecimento, o legislador outorga o atributo de indisponibilidade no sentido de inalienabilidade a quem quer que seja e a qualquer título. Aos segundos, dispensa o legislador um tratamento mais brando, o que é a regra geral, permitindo a sua disposição" (A intervenção do Ministério Público no processo civil brasileiro. $2^{\mathrm{a}}$ ed. rev. atual. São Paulo: Saraiva, 1998, p. 45-46).

${ }^{324} \mathrm{~V}$. item 4.2.2.

${ }^{325}$ Art. $1^{\circ}$ da Lei n8.078/90.
} 
Resta apenas fazer uma ressalva quanto à atuação do Ministério Público na tutela coletiva de interesses individuais homogêneos. Vimos que essa tutela visa a obtenção de sentença genérica, nos termos do art. 95 do Código de Defesa do Consumidor e que qualquer dos legitimados pode propor a execução coletiva da sentença genérica. Nesse caso, porém, é necessário interpretar a lei em conformidade com a Constituição Federal para concluir que o Ministério Público não está legitimado à propositura dessa execução coletiva, uma vez que a tutela executiva não revela interesse social ${ }^{326}$. Não é que a execução esteja afastada do campo de legitimação do parquet porque não tem caráter coletivo, porque, excepcionalmente, pode ter esse caráter; o problema é que o Ministério Público não pode ir até o ponto em que substitui a vontade dos titulares dos interesses, que são disponíveis, para executar sentença genérica favorável contra a vontade dos interessados. Porém, se esses titulares não manifestarem esse interesse, a execução poderá ser promovida em benefício do fundo de direitos transindividuais, hipótese para a qual, naturalmente, a legitimidade do Ministério Público volta a ser plena, pois também se dirige para a defesa de interesses sociais, tanto quanto no momento da propositura, pois os recursos do fundo predispõem-se à reconstituição dos bens lesados ${ }^{327}$.

5.1.2 - Estudo de caso: indisponibilidade e legitimação do Ministério Público

O acórdão proferido nos Embargos Declaratórios no Agravo Regimental no Recurso Extraordinário n. 470.135-9 $9^{328}$ tratou da alegação de omissão e contradição no acórdão embargado. Para o embargante, a Corte teria deixado de pronunciar-se sobre a alegação de ilegitimidade do Ministério Público para propositura de ação civil pública em defesa de direitos individuais homogêneos, no caso, aqueles decorrentes de contratos de financiamento no âmbito do Sistema Financeiro da Habitação.

\footnotetext{
${ }^{326}$ No mesmo sentido, Teori Albino Zavascki (Ministério Público, ação civil pública e defesa de direitos individuais homogêneos. In: Revista Forense, vol. 92, n. 333, Rio de Janeiro, jan./fev./mar. 1996, p. 133) e Hugo de Brito Machado (O Ministério Público e os direitos individuais homogêneos. In: Repertório IOB de Jurisprudência, vol. III, n. 18, São Paulo, $2^{a}$ quinzena de set. 1996, p. 324). Antonio Gidi sustenta, com razão, que "os direitos individuais homogêneos globalmente considerados são indisponíveis pelo grupo de vítimas. Disponível é, apenas, cada um dos direitos isolada e individualmente considerados, por parte do seu titular individual, e não os direitos individuais homogêneos como um todo (coletivamente considerados)" (Coisa julgada e litispendência em ações coletivas. São Paulo: Saraiva, 1995, p. 50).

${ }^{327}$ Art. 100 do Código de Defesa do Consumidor, c/c art. 13 da Lei n. 7.347/85.

${ }^{328}$ Acórdão de 22/05/2007.
} 
No voto do relator, acompanhado pela totalidade dos ministros da Segunda Turma do Supremo Tribunal Federal, o recurso foi acolhido em parte, apenas para corrigir erro material na ementa do acórdão embargado e para revogar a condenação em litigância de má-fé decorrente de abuso de prerrogativa processual consistente em interposição de recurso manifestamente improcedente. No mérito, o acórdão embargado foi mantido, sob o fundamento de que a questão relativa à legitimidade do Ministério Público foi desatada com base em jurisprudência do próprio tribunal inteiramente aplicável ao caso.

$\mathrm{O}$ voto menciona que o tribunal tem considerado configurada a legitimidade ad causam do Ministério Público para a "proteção de direitos individuais homogêneos, sempre que estes, tomados em conjunto, ostentem dimensão de grande relevo social". Tal dimensão, conforme o voto condutor, ocorrerá quando "estiver ligada a valores e preceitos que sejam pertinentes a toda a coletividade" e estejam "hospedados na Constituição da República Federal". Por outras palavras, a legitimidade do Ministério Público seria extraída da circunstância de os interesses individuais homogêneos terem grande relevo social, que ocorre quando tais interesses digam respeito a toda a coletividade e estejam previstos na Constituição Federal.

$\mathrm{O}$ voto menciona dois acórdãos paradigmas, um considerando presente a legitimidade do parquet quando se trata de abusividade ou ilegalidade na cobrança de mensalidades escolares (RE n. 195.056, mencionando também mais precedentes nesse sentido), outro decidindo pela legitimação do Ministério Público em caso de discussão sobre direitos de mutuários do Sistema Financeiro da Habitação (RE n. 247.134). No primeiro, a fundamentação estaria na circunstância de os interesses (lá com a denominação "direitos") individuais homogêneos constituírem subespécie dos interesses coletivos em sentido estrito. Nesse caso, haveria legitimação expressa no art. 129, inciso III, da Constituição Federal ("outros interesses difusos e coletivos"). No segundo paradigma, o fundamento estaria na previsão da legislação infraconstitucional referente às relações de consumo, pois os mutuários seriam consumidores em sentido largo, além de os interesses individuais homogêneos poderem ser considerados espécie de interesses coletivos e os direitos à moradia constituírem direito social por disposição constitucional $\left(\operatorname{art.} 6^{\circ}\right)$.

A primeira observação sobre a fundamentação adotada no voto, bem como nos julgados que lhe serviram de precedentes, é a falta de um critério objetivo para 
inferir a legitimidade do Ministério Público no caso concreto. O critério adotado é subjetivo e casuístico, isto é, se o interesse é considerado socialmente relevante o bastante para fazer com que a intervenção do parquet pareça necessária e razoável, então ela é admitida, caso contrário não. Isso não quer dizer que, no caso concreto examinado, outro seria o resultado se adotado critério diverso, menos subjetivo. Quer dizer apenas não existir previsibilidade quanto ao posicionamento do tribunal nessa matéria, porque outras matérias, ainda que de relevância social evidente, poderão ser tidas como passíveis de proteção pelo Ministério Público ou não, dependendo de os julgadores entenderem que a relevância social é suficiente para isso.

Como visto, o critério é a presença de grande relevo social; seus indicadores, devem dizer respeito a toda a coletividade e estar previstos na Constituição Federal. Dizer respeito a toda a coletividade pode até ser medida da relevância social, mas qual a coletividade a ser considerada? A população do Estado, no caso do Ministério Público Estadual e a do país, tratando-se de Ministério Público Federal? E se não atingisse toda a coletividade, então teríamos de admitir a ausência de legitimidade ainda que se tratasse da mesma matéria. Por exemplo, se determinada relação de consumo, abstraída a normatização legal expressa existente, não alcançasse toda uma coletividade, ainda que fosse apenas uma região, então ela não teria grande relevância social e não poderia ser defendida pelo Ministério Público.

Haver previsão na Constituição Federal também não parece ser um parâmetro útil. Com efeito, é difícil imaginar interesses individuais homogêneos não previstos na carta constitucional. Todos eles, com certeza, apresentam relevo social. Mas constitui tarefa bem difícil deliberar quais podem ser considerados de grande relevo social, quais seriam de médio relevo e quais os de baixo. Além disso, se o critério é a previsão constitucional, todos os interesses sociais e individuais indisponíveis podem ser defendidos pelo Ministério Público (art. 127), não apenas os de "grande relevo social", caso se entenda que estes são menos abrangentes do que aqueles.

Os precedentes mencionados como paradigmas oferecem um critério menos subjetivo, mas de procedência dificilmente defensável. Trata-se de admitir que os interesses individuais homogêneos são subespécie dos interesses coletivos em sentido estrito, estes cuja defesa foi constitucionalmente atribuída ao Ministério Público. Se os interesses individuais homogêneos pudessem ser assim classificados, efetivamente sua 
defesa poderia ser promovida pelo parquet. Não há dúvida tratar-se de uma tese sedutora para os que pretendem demonstrar essa legitimidade.

Mas aqui não se trata de uma classificação doutrinária ${ }^{329}$, mas de uma interpretação constitucional. Quando escreveu "interesses coletivos", o constituinte quis englobar os que hoje são denominados interesses coletivos em sentido estrito e também os interesses individuais homogêneos, de modo a incluir todos eles na esfera de legitimação do Ministério Público, sem exceção?

Não se afigura uma interpretação razoável, mesmo entendendo que podia não existir ainda a denominação (ou a sua consagração), mas já existia uma preocupação pela sua proteção, como é exemplo a previsão do art. 48 do Ato das Disposições Constitucionais Transitórias, determinando a promulgação de código de defesa do consumidor. Isso porque o constituinte tratou dos interesses individuais quando falou da legitimidade do Ministério Público, especificando os que fossem, ao mesmo tempo, indisponíveis, como mencionado acima.

A última fundamentação a ser destacada, sem dúvida, é a mais pertinente. Consiste em considerar configurada a legitimidade do Ministério Público em decorrência do fato de que as relações jurídicas formadas pelos contratos do Sistema Financeiro da Habitação são consideradas de natureza consumerista ${ }^{330}$. Nesse caso, a relevância social capaz de induzir a legitimação do parquet é expressamente prevista na legislação (art. $1^{\circ}$ do Código de Defesa do Consumidor), ainda que isso não tenha sido destacado no acórdão. Mais uma vez demonstrando que o critério escolhido é subjetivo e casuístico, o acórdão menciona apenas que, neste caso, a legitimação encontraria amparo nos dispositivos constitucionais já mencionados, que, como visto, não especificam quais interesses individuais homogêneos encontram-se dentro do campo de legitimação do Ministério

\footnotetext{
${ }^{329}$ V. capítulo 1 , item 1.3 .

${ }^{330}$ Nesse sentido dispõe o parágrafo $2^{\circ}$ do art. $3^{\circ}$ do Código de Defesa do Consumidor que "serviço é qualquer atividade fornecida no mercado de consumo, mediante remuneração, inclusive as de natureza bancária, financeira, de crédito e securitária, salvo as decorrentes das relações de caráter trabalhista". Não obstante, vigorosa foi a defesa da tese de que, não havendo remuneração paga diretamente pelo poupador ao banco, não se estava diante de relação de consumo (v. Arnoldo Wald, Contratos bancários de depósito em caderneta de poupança. Descabimento de ação civil pública e irretroatividade da lei. In: WALD, Arnoldo. Aspectos polêmicos da ação civil pública. São Paulo: Saraiva, 2003, p. 65). A tese acabou refutada pelo Superior Tribunal de Justiça, que editou a Súmula n. 297, prescrevendo que "o Código de Defesa do Consumidor é aplicável às instituições financeiras".
} 
Público, bem como na cláusula genérica do inciso IX do art. 129 ("exercer outras funções que lhe forem conferidas, desde que compativeis com sua finalidade").

As demais questões processuais tratadas no acórdão fogem ao escopo deste trabalho.

\section{2 - O pedido e a sentença}

\subsection{1 - Aspectos polêmicos}

Em tema de pedido na tutela coletiva, discute-se a possibilidade de ação visando a declaração do direito de não se submeter a determinada obrigação legal, sob o fundamento da sua inconstitucionalidade. São óbvias as ressalvas feitas ao pedido de declaração de inconstitucionalidade de lei ou ato normativo, matéria exclusiva de ação constitucionalmente prevista, a ação direta de inconstitucionalidade, cuja legitimidade encontra previsão expressa também na Constituição Federal (art. 103): a questão da inconstitucionalidade, evidentemente, não pode constituir pedido na ação coletiva, mas tão-somente causa de pedir, qualquer que seja a hipótese.

Mas as restrições não se resumem a essa situação. Se o pedido na ação coletiva depender do conhecimento de questão prejudicial consistente na declaração incidental de inconstitucionalidade de obrigação legal, tal declaração teria efeitos similares aos da ação direta de inconstitucionalidade, uma vez que a coisa julgada tem efeitos erga omnes. Mesmo a limitação dos efeitos da sentença, por força do art. $2^{\circ}$-A da Lei $n$. 9.494/97, não afastaria o problema, porque implicaria estabelecer regulamentação jurídica num Estado em conflito com aquela em vigor no plano nacional, contrariando o princípio da unidade do direito material. Por essa razão, parte da doutrina entende incabível a ação coletiva nessas hipóteses, ressalvando os casos de descabimento de ação direta de inconstitucionalidade, como a impugnação de leis de efeitos concretos, de leis anteriores à carta constitucional atual ou de leis municipais perante a Constituição Federal ${ }^{331}$.

A jurisprudência porém, incluindo a do Supremo Tribunal Federal, tem entendido, com acerto, que é possível o controle difuso de constitucionalidade via de ação

\footnotetext{
${ }^{331}$ Nesse sentido, Pedro da Silva Dinamarco, Ação civil pública. São Paulo: Saraiva, 2001, p. 280.
} 
civil pública, uma vez que não se trata de ação objetiva dissimulada, nem de pedido de fundo declaratório de inconstitucionalidade, nem imune ao controle de constitucionalidade pelo próprio Supremo Tribunal Federal, em sede de recurso extraordinário ${ }^{332}$.

Quanto ao objeto do pedido, questão tormentosa tem sido a possibilidade da veiculação de matéria tributária em ação coletiva para tutela de interesses individuais homogêneos. A questão tem sido confundida com a legitimação do Ministério Público, de maneira que é preciso, antes de tudo, aclará-la.

Como visto no item 5.1.1, a legitimidade do Ministério Público depende da caracterização legal do interesse como sendo de relevância social, seja pela sua indisponibilização, seja pela atribuição expressa de legitimidade do parquet para a sua defesa, seja de declaração específica da lei nesse sentido. Nada disso é encontrado no tocante às relações jurídicas tributárias, de maneira que, partindo-se dessas premissas, é seguro afirmar que o Ministério Público não possui legitimidade para ajuizar ação coletiva nessa seara.

No que respeita à natureza do interesse relacionado com o fato gerador tributário, a seu turno, não há qualquer dúvida de tratar-se de interesses individuais homogêneos, uma vez decorrerem de origem comum, no caso, a norma jurídica que prevê a hipótese imponível ${ }^{333}$. Também fora de discussão a predominância dos elementos homogêneos, afastada a necessidade de comprovação de qualquer causa individualizada. Evidente, por fim, a conveniência da tutela coletiva, tendo em vista as dificuldades de acesso à justiça dos lesados, que sequer têm conhecimento da ilegitimidade de determinada exigência, bem como a importância da prevenção de inúteis processos individuais idênticos. O entendimento de que descabe ação civil pública porque a condição de contribuinte não se confunde com a de consumidor, já observado em acórdão do próprio Supremo Tribunal Federal ${ }^{334}$, é equivocado porque a própria Lei n. 7.347/85, em seu art. 21, prevê a aplicação, à defesa de quaisquer interesses individuais homogêneos, de todos

\footnotetext{
${ }^{332} \mathrm{~V}$. item 5.2.2.

${ }^{333}$ No mesmo sentido, James Marins (Ações coletivas em matéria tributária. In: Revista de Processo n. 76, São Paulo, Editora Revista dos Tribunais, out./dez. 1994, p. 100) e Carlos Mário da Silva Velloso (Processo judicial tributário: medidas judiciais que o integram e a legitimidade do Ministério Público para a ação civil pública que tem por objeto o não pagamento de um tributo. In: Revista de Direito Bancário e do Mercado de Capitais n. 6, São Paulo, Editora Revista dos Tribunais, set./dez. 1999, p. 15).

${ }^{334}$ RE 195.056/PR, Relator Min. Carlos Velloso, DJ de 30/05/2003.
} 
os institutos processuais do Código de Defesa do Consumidor, entre os quais a ação coletiva para a defesa de interesses individuais homogêneos (arts. 91 a 100).

Desse modo, pode-se dizer que, em princípio, uma associação de contribuintes poderia ajuizar ação civil pública para tutela de interesses individuais homogêneos ligados à matéria tributária ${ }^{335}$. Ocorre que sobreveio a nova redação do parágrafo único do art. $1^{\circ}$ da Lei n. 7.347/85, que impede a propositura de ação civil pública em matéria tributária, de contribuições previdenciárias ou de fundos institucionais de beneficiários determináveis ${ }^{336}$. Nesse caso, por mais lamentável que se possa entender tenha sido essa vedação, a tutela coletiva de interesses individuais homogêneos em matéria tributária não é cabível, não porque a ação civil pública não seja instrumento, em tese, compatível com essa tutela, mas porque a adequação processual foi afastada pela lei. Não se vislumbra, também, inconstitucionalidade efetiva no dispositivo, porque se as hipóteses de cabimento da ação civil pública podem ser estendidas pelo legislador, também podem ser restringidas.

Outra exigência legal que tem causado controvérsia é a obrigatoriedade de comprovar, na petição inicial, a autorização dos membros de associação para a propositura de ação coletiva, bem como identificar os membros por nome e endereços na petição inicial (art. $2^{\circ}$-A da Lei n. 9.494/97). Não obstante as duras críticas feitas pela doutrina $^{337}$, muitos tribunais chegaram a acatar a norma, até que a jurisprudência consolidou-se no sentido de que a norma é inaplicável, por inconstitucional, uma vez que as associações possuem legitimidade constitucional para representar seus filiados em juízo, sem a exigência de autorização específica, conforme incisos LXX do art. $5^{\circ}$ e III do art. $8^{\circ}$

\footnotetext{
${ }^{335}$ Também há entendimento institucional do Ministério Público de São Paulo entendendo haver legitimidade do parquet para propor ação civil pública versando essa matéria, de acordo com a Súmula n. 7 de seu Conselho Superior, verbis: "na defesa de interesses individuais homogêneos que tenham expressão para a coletividade, o Ministério Público é parte legítima para ajuizar ação civil pública em matéria tributária".

${ }^{336} \mathrm{~V}$. item 4.3.3.

${ }^{337}$ V. Pedro Lenza, que entende inaplicável por confundir os institutos da representação processual e da legitimação para agir na tutela jurisdicional coletiva, qualificando de esdrúxula a exigência da relação nominal dos associados e grotesca a de indicação dos respectivos endereços (Teoria geral da ação civil pública. São Paulo: Editora Revista dos Tribunais, 2003, p. 279). Também sustentando a evidente atecnia, v. Rodolfo de Camargo Mancuso (Jurisdição coletiva e coisa julgada. São Paulo: Editora Revista dos Tribunais, 2007, p. 279).
} 
da Constituição Federal, normas permissivas que não podem ser restringidas pela legislação ${ }^{338}$.

Matéria muito discutida é a da natureza da sentença genérica do art. 95 do Código de Defesa do Consumidor ("em caso de procedência do pedido, a condenação será genérica”). Forte é a corrente entendendo tratar-se de sentença condenatória, tendo em vista a própria expressão escolhida pelo legislador para apontar o seu conteúdo (“condenação") ${ }^{339}$. Mas também existe o entendimento no sentido de tratar-se de sentença meramente declaratória, sob o fundamento de que, seja qual for a definição adotada para a sentença condenatória, diante das diversas correntes doutrinárias existentes, a sentença genérica não o preenche. Conforme explica Teori Albino Zavascki, a sentença genérica não constitui título executivo, nem constitui a sanção à violação do direito ou tampouco constitui o estado de sujeição do condenado à execução forçada, tendo em vista necessitar de complementação, por meio de liquidação, dos elementos obrigacionais que expressa ${ }^{340}$.

Definir se a sentença genérica é declaratória ou condenatória, porém, apresenta relevância menor. De fato, é possível falar em carga declaratória ou condenatória das sentenças, de maneira que a sentença genérica, não há dúvida, tem ambas, daí a discussão. Se ela visa uma condenação completa, após a liquidação, motivo pelo qual o legislador falou em condenação genérica, não há dúvida de que possui alguma carga condenatória, ainda que, diante dessa mesma incompletude, a carga declaratória seja, realmente, ainda maior.

A relevância maior encontra-se em outra questão, que é a de saber se a sentença pode ser executável diretamente ou se requer a prática de outros atos ou mesmo a instauração de outro processo. Com as reformas efetivadas no Código de Processo Civil nos últimos anos, uma das tendências mais fortes tem sido o sincretismo dos processos de

\footnotetext{
${ }^{338}$ Nesse sentido, acórdão do Superior Tribunal de Justiça no Recurso Especial n. 866350/AL, Relator Min. Arnaldo Esteves Lima, DJE de 01/09/2008, e do Tribunal Regional Federal da Quinta Região nos Embargos de Declaração na Apelação em MS n. 89704/01/PE, DJ de 18/11/2005, Relatora Desembargadora Federal Margarida Cantarelli. V. também item 4.4.2.

339 Pela natureza condenatória, Ada Pellegrini Grinover (Código brasileiro de defesa do consumidor comentado pelos autores do anteprojeto. $5^{\mathrm{a}}$ ed. rev. atual. amp. Rio de Janeiro: Forense Universitária, 1998, p. 687); José Manoel Arruda Alvim (Código do consumidor comentado. 2a ed. São Paulo: Editora Revista dos Tribunais, 1995, p. 432); Rodolfo de Camargo Mancuso (Manual do consumidor em juízo. $3^{\mathrm{a}}$ ed. rev. atual. amp. São Paulo: Saraiva, 2001, p. 128).

340 Ações coletivas, p. 173. V. também Luiz Paulo da Silva Araújo Filho, Ações coletivas: a tutela jurisdicional dos direitos individuais homogêneos. Rio de Janeiro: Forense, 2000, p. 137.
} 
conhecimento e de execução, dispensando-se, após a sentença, a instauração de nova relação jurídico-processual, via de autorização para o juiz impor medidas coercitivas para cumprimento da sentença em face do réu na mesma relação já instaurada. O inciso Ido art. 475-N do Código de Processo Civil, incluído pela Lei n. 11.232/05, dispõe que a sentença que reconheça a existência de qualquer obrigação de fazer, não fazer, entregar coisa ou pagar quantia constitui título executivo judicial. Com base nesse dispositivo, a sentença que declare a existência de determinada relação jurídica obrigacional, antes considerada "meramente declaratória", agora pode ser executada diretamente. Mais ainda, a sentença que negue a declaração de inexistência de uma relação jurídica nesses termos, também pode ser executada pelo réu, que dela é beneficiário, como se tivesse pleiteado a declaração positiva equivalente ${ }^{341}$.

A indagação que se faz, naturalmente, é se tal dispositivo aplica-se à sentença genérica do art. 95 do Código de Defesa do Consumidor. A resposta é negativa porque o novo dispositivo dirige-se para as obrigações perfeitamente determinadas, cuja declaração é suficiente para fazer certa uma obrigação que já é também líquida. E a finalidade do legislador, naturalmente, foi a de evitar a repetição de atos processuais inúteis, apenas para agregar uma carga executiva a um provimento judicial que já é definitivo, imutável e bastante para ensejar cumprimento ${ }^{342}$. Ocorre que a sentença genérica, evidentemente, não é líquida, não basta para possibilitar o cumprimento por parte do réu.

A discussão sobre a natureza da sentença genérica, mais do que nunca, apresenta agora importância apenas relativa, porque, atualmente, as sentenças simplesmente declaratórias de obrigação têm carga executiva igual à das sentenças

\footnotetext{
${ }^{341}$ Em virtude dessas alterações legislativas, a doutrina começa a propor até mesmo nova classificação das sentenças quanto ao tipo de provimento pleiteado. Vicente Greco Filho sugere diferenciar as ações declaratórias puras, nas quais o autor expressamente renuncie expressamente ao efeito executivo, e as declaratórias executivas, com incidência do art. 475-N, inciso I, do Código de Processo Civil (Uma visão atual do sistema processual e da classificação das ações, disponível em <http://www.oabsp.org.br/noticias/2008/11/26/5248/>, acesso em 12/01/2009).

${ }^{342}$ Teori Albino Zavascki, na relatoria do Recurso Especial n. 588202/PR (STJ, Primeira Turma, DJ de 25/02/2004, p. 123), antes ainda da modificação legal, entendeu que "tem eficácia executiva a sentença declaratória que traz definição integral da norma jurídica individualizada. Não há razão alguma, lógica ou jurídica, para submetê-la, antes da execução, a um segundo juízo de certificação, até porque a nova sentença não poderia chegar a resultado diferente do da anterior, sob pena de comprometimento da garantia da coisa julgada, assegurada constitucionalmente. E instaurar um processo de cognição sem oferecer às partes e ao juiz outra alternativa de resultado que não um, já prefixado, representaria atividade meramente burocrática e desnecessária, que poderia receber qualquer outro qualificativo, menos o de jurisdicional".
} 
condenatórias típicas. Porém, se a sentença proferida em ação coletiva em defesa de interesses individuais homogêneos dispensar liquidação ${ }^{343}$, ela constituirá título executivo ainda que se entenda ser declaratória a sua natureza, nesse caso, por força da inovação em exame, trazida com as reformas do Código de Processo Civil.

Outra questão alvo de polêmica é a norma do art. $2^{\circ}$-A da Lei n. 9.494/97, na redação dada pela Medida Provisória n. 2.180-35, de 24/08/2001, estipulando que "a sentença civil prolatada em ação de caráter coletivo proposta por entidade associativa, na defesa dos interesses e direitos dos seus associados, abrangerá apenas os substituídos que tenham, na data da propositura da ação, domicílio no âmbito da competência territorial do órgão prolator". Não obstante as críticas da doutrina a mais essa restrição do âmbito da tutela coletiva ${ }^{344}$, a jurisprudência tem aplicado o dispositivo normalmente (Superior Tribunal de Justiça, Agravo Regimental no Recurso Especial n. 1029223, DJE de 29/09/2008, Relator Min. Paulo Gallotti; Superior Tribunal de Justiça, Recurso Especial n. 665947, DJ de 12/12/2005, Relator Min. José Delgado).

Não há dúvida tratar-se de um enorme retrocesso para a plena utilização da tutela coletiva para os fins a que se vocaciona ${ }^{345}$, "atomizando" conflitos que, a muito custo, foram "molecularizados". Mas a lei pode limitar a competência para o conhecimento de ações coletivas; a inconstitucionalidade da medida, por sua vez, ficaria mais bem configurada se ela impedisse pelo menos o acesso à jurisdição coletiva, mas nem isso pode-se afirmar: os interessados, além da via individual, podem ajuizar ações coletivas, porém tantas quantas forem necessárias para cobrir todos os foros onde estiverem domiciliados os interessados. Além disso, a restrição não se aplica ao Ministério Público, nem aos órgãos públicos. Nesse sentido, a medida constitui mais um desestímulo à iniciativa das associações na defesa dos interesses transindividuais do que um bloqueio ao acesso à justiça.

\footnotetext{
${ }^{343}$ V. capítulo 3, item 3.2.

${ }^{344} \mathrm{~V}$. item 4.3.3.

${ }^{345}$ V. capítulo 2, item 2.4.1.
} 
5.2.2 - Estudo de caso: o controle de constitucionalidade e a tutela coletiva

Tendo sido ajuizada ação civil pública em defesa de interesses individuais homogêneos, cujo objeto era o ressarcimento de prejuízo decorrente de crédito referente a correção monetária em contas de cadernetas de poupança de acordo com dispositivo legal alegadamente inconstitucional, sobreveio sentença de procedência, confirmada em segundo grau. Concomitantemente à interposição dos recursos extraordinário e especial, o banco réu ajuizou a Reclamação n. 600-0/190 ${ }^{346}$ perante o Supremo Tribunal Federal, sustentando que o tribunal local teria estabelecido "uma inconstitucionalidade no plano nacional, em relação a alguns aspectos da Lei $n^{o}$ 8024/1990, que somente ao Supremo Tribunal Federal caberia decretar".

O acórdão decidiu, por maioria de $\operatorname{votos}^{347}$, que não há afronta à competência do tribunal, via da ação direta de inconstitucionalidade, porque a decisão não fica imune ao controle concentrado de constitucionalidade, via de recurso extraordinário, não obstante a eficácia erga omnes da decisão. A ação objeto da reclamação refere-se, segundo o acórdão, à relação jurídica decorrente de contrato expressamente identificado, não a declaração de inconstitucionalidade da lei cuja incidência estaria ferindo o ato jurídico perfeito e o ato adquirido. Em consequência, ainda que a decisão afaste a incidência da lei, o fará mediante declaração de inconstitucionalidade incidenter tantum, constituindo controle difuso de constitucionalidade, possível em ação civil pública como em qualquer outra, diante da convivência dos dois sistemas de controle de constitucionalidade, difuso e concentrado, no sistema brasileiro.

O voto divergente, do Ministro Marco Aurélio $^{348}$, expressou manifestação pela caracterização da usurpação de competência do supremo Tribunal Federal, entendendo que "no caso, esse controle se mostrou abstrato, em face da abrangência do provimento judicial próprio à ação civil pública, e isso somente poderia

\footnotetext{
${ }^{346}$ Julgamento de 03/09/97.

347 Cópias anexas apenas do voto vencedor, do Relator Min. Néri da Silveira. Os demais votos estão disponíveis em <http://www.stf.jus.br/portal/inteiroTeor/obterInteiroTeor.asp?numero=600\&classe=Rcl>, acesso em 02/01/2009. O julgamento foi conjunto com outras duas reclamações semelhantes, também por alegada usurpação de competência por ações civis públicas contra outros bancos em que se visava igualmente condenação ao pagamento de diferenças de correção monetária com base na inconstitucionalidade da mesma lei federal.

${ }^{348}$ Inicialmente, o Ministro Nelson Jobim também se manifestou pelo acolhimento da reclamação, alterando seu voto, posteriormente, para acompanhar o relator.
} 
ocorrer na via própria da ação direta de inconstitucionalidade, da competência do Supremo Tribunal Federal. Submeteu-se ao Judiciário caso linear que, ao menos em relação ao Banco-Reclamante, acabaria por obstaculizar a formalização de outros".

O cerne da questão consiste em saber se a usurpação da competência do Supremo Tribunal Federal no controle concentrado fica caracterizada pela obtenção de efeitos similares por meio de outra ação (ou outras ações) ou se é exigível algo mais para essa finalidade, isto é, que o meio processual utilizado seja vedado pelo ordenamento. Ocorre que a simples obtenção de efeitos similares não pode ser considerada suficiente porque nem mesmo o ajuizamento de inúmeras ações civis públicas, por mais que esvaziem o objeto de eventual ação direta, encontra proibição no ordenamento jurídico. Basta dizer que o mesmo efeito poderia ser obtido com milhares de ações individuais, com mais facilidade se em litisconsórcio, e, nesse caso, não seria sequer possível cogitar em usurpação de competência, ainda que se trate de problema sem solução no Direito comparado, conforme lembrou o Ministro Sepúlveda Pertence em seu voto.

As duas hipóteses de ação propostas em instâncias inferiores, já ocorridas, vedadas pelo ordenamento jurídico e que obteriam efeitos similares à ação direta de inconstitucionalidade, foram também lembradas pelo Ministro Sepúlveda Pertence. A primeira foi uma ação declaratória de inconstitucionalidade de lei estadual que concedia meia-entrada a estudantes, proposta contra a própria unidade federativa, sem que houvesse um litígio concreto, muito menos legitimidade passiva. Tratava-se de evidente ação direta de inconstitucionalidade dissimulada.

A segunda foi uma ação direta de inconstitucionalidade para a qual, em princípio, o Supremo Tribunal Federal não teria competência, porque impugnava lei municipal em face da Constituição Federal. Ocorre que o sistema brasileiro, mesmo nos regimes constitucionais anteriores, não admitia o controle de constitucionalidade concentrado de lei municipal frente à Constituição Federal, nem mesmo perante o Supremo Tribunal Federal, menos ainda perante tribunais locais. O que passou a ser admitido, tãosomente, foi o controle de constitucionalidade de lei municipal, assim como de leis 
estaduais, perante a Constituição Estadual, ainda que a norma constitucional estadual reproduza dispositivo constitucional federal ${ }^{349}$.

Mas nem sequer de obtenção de efeitos semelhantes à ação direta de inconstitucionalidade pode-se cogitar. De fato, não há como sustentar que os efeitos da sentença da ação civil pública seriam os mesmos do controle abstrato, por pelo menos três razões. A primeira é que o provimento pleiteado é condenatório, inconfundível com o pedido na ação direta de inconstitucionalidade, seja a natureza da sentença a ele correspondente considerada declaratória ou constitutiva. A segunda é que, como já referido, somente uma multiplicidade de ações coletivas poderia aproximar-se de obter efeitos semelhantes à ação direta e, no caso, o réu era apenas um banco. A terceira é que a ação civil pública não projetaria efeitos para o futuro da eventual declaração de inconstitucionalidade, seja porque a resolução de questão prejudicial não se insere no dispositivo, não recaindo sobre tal decisão os efeitos da coisa julgada (art 469, inciso I, do Código de Processo Civil) $)^{350}$, seja porque as relações jurídicas objeto da lide não estão inseridas na lei cuja inconstitucionalidade constitui questão prejudicial.

Em resumo, tem-se, na hipótese, ação civil pública que não dissimula ação direta de inconstitucionalidade, não veicula pedido vedado pelo ordenamento, não projeta seus efeitos para o futuro e não escapa ao controle de constitucionalidade do Supremo Tribunal Federal na via difusa. Sendo assim, não há usurpação da competência da corte constitucional, nem qualquer outro impedimento ao seu normal processamento.

Por fim, o relator assentou que não apenas o mérito da causa veiculada na ação civil pública, mas também o próprio cabimento da ação civil pública para a veiculação do pedido ainda poderiam ser objeto de discussão, em sede de recurso extraordinário, que efetivamente já tinha sido interposto, àquela altura.

\footnotetext{
${ }^{349}$ Nesse sentido, a Reclamação n. 338 (Relator Min. Moreira Alves, RTJ 147/404) e a Medida Cautelar em Recurso Extraordinário n. 161390/AL (Relator Min. Sepúlveda Pertence, DJ de 23/04/93, p. 6928).

${ }^{350}$ Nesse sentido, v. José Adonis Callou de Araújo Sá, Ação civil pública e controle de constitucionalidade. Belo Horizonte: Del Rey, 2002, p. 130.
} 
5.3 - A coisa julgada

\subsection{1 - Aspectos polêmicos}

A limitação territorial da coisa julgada também constitui matéria em relação à qual a doutrina tem dirigido duras críticas, seja por sua inconveniência, seja por sua inutilidade $\mathrm{e}^{351}$ ou mesmo inconstitucionalidade ${ }^{352}$. Todavia, da mesma forma que ocorre com a restrição da abrangência da sentença nas ações propostas por associações ${ }^{353}$, o posicionamento doutrinário não tem conseguido convencer os tribunais que têm aplicado normalmente a limitação, inclusive nas ações coletivas versando direitos de consumidores (Superior Tribunal de Justiça, Embargos de Declaração no Agravo Regimental nos Embargos de Divergência no Recurso Especial, Corte Especial, DJE de 20/10/2008, Relator Min. Luiz Fux; Superior Tribunal de Justiça, Agravo Regimental nos Embargos de Divergência no Recurso Especial n. 253589, Corte Especial, DJE de 01/07/2008, Relator Min. Luiz Fux).

Essa restrição, evidentemente, constitui outro enorme retrocesso para a plena utilização da tutela coletiva: também aqui a consequência é "atomizar" conflitos que foram "molecularizados" a duras penas, exatamente o oposto do que se pretende para ampliar o acesso à justiça e evitar o acúmulo de causas repetitivas nos tribunais ${ }^{354}$. Mas a limitação subjetiva da coisa julgada é típica matéria de lei, ainda que o critério escolhido não apenas contrarie o objetivo de disseminação da tutela coletiva mas também enseje a contrariedade de decisões sobre o mesmo tema, ao utilizar, estranhamente, critérios de

\footnotetext{
${ }^{351}$ V. Ada Pellegrini Grinover (Código brasileiro de defesa do consumidor comentado pelos autores do anteprojeto. $5^{\mathrm{a}}$ ed. rev. atual. amp. Rio de Janeiro: Forense Universitária, 1998, p. 722-726) ; v. também Nelson Nery Júnior e Rosa Maria de Andrade Nery (Código de processo civil comentado e legislação extravagante. $7^{\mathrm{a}}$ ed. rev. amp. São Paulo: Editora Revista dos Tribunais, 2003, p. 1541).

${ }^{352}$ V. Pedro Lenza (Teoria geral da ação civil pública. São Paulo: Editora Revista dos Tribunais, 2003, p. 270-276); v. também José Marcelo Menezes Vigliar (Ação civil pública. $5^{\mathrm{a}}$ ed. rev. amp. São Paulo: Atlas, 2001, p. 120-122).

${ }^{353} \mathrm{~V}$. item 5.2.1.

354 Todavia, também há argumentos na doutrina em favor da restrição. Pedro da Silva Dinamarco aponta cinco deles, a saber: (a) trata-se de opção política do legislador; (b) há necessidade de respeitar o princípio federativo; (c) a lei privilegiou a proximidade do dano como critério de fixação da competência; (d) a lei afastou o obstáculo ao acesso à justiça, em desfavor do autor coletivo ou do litisconsorte individual, representado pelo eventual ajuizamento, em foro distante, de ação coletiva conexa à causa do co-legitimado ou de seu interesse; (e) a lei afastou o possível cerceamento do direito de defesa consistente na possibilidade de o réu, em ação de repercussão nacional, ter de defender-se longe de sua sede (Competência, conexão e prevenção nas ações coletivas. In: MILARÉ, Édis (coord.). A ação civil pública - Após 20 anos: efetividade e desafios. São Paulo: Editora Revista dos Tribunais, 2005, p. 507-508).
} 
competência para instituir tal limitação ${ }^{355}$. Assim, tal restrição também tem sido aplicada pelos tribunais.

Mas a aplicabilidade da norma merece reparos. Quanto à defesa de interesses individuais homogêneos de consumidores, a crítica refere-se também ao fato de não ter sido alterado o art. 103 do Código de Defesa do Consumidor, que regula precisamente os limites subjetivos da coisa julgada na tutela coletiva consumerista. Mesmo entendendo-se que as ações previstas na Lei da Ação Civil Pública e no Código de Defesa do Consumidor sejam uma só, se existe uma disciplina específica na lei especial, ela deve prevalecer $^{356}$. Assim, os limites subjetivos da coisa julgada para esse tipo de ação são os dispostos no inciso III do art. 103, ou seja, "erga omnes, apenas no caso de procedência do pedido, para beneficiar todas as vítimas e seus sucessores", sem qualquer limitação de natureza territorial.

Quanto às ações em defesa de outros interesses individuais homogêneos, a redação original do art. 16 da Lei n. 7.347/85 permitia estender a aplicação do art. 103, inciso III e parágrafo $2^{\circ}$, do Código de Defesa do Consumidor também às ações que não tratassem de relações de consumidores, uma vez que na época da sua edição a Lei da Ação Civil Pública sequer tratava de interesses individuais e a Lei n. 8.078/90 inseriu naquela a norma de extensão (art. 21). Porém, a situação mudou após a alteração imposta pela Lei n. 9.494/97, uma vez que a utilização das normas do CDC às ações em defesa de interesses individuais não consumeristas só pode ser feita "quando cabível", isto é, quando não houver norma específica na própria Lei da Ação Civil Pública. Entender que a modificação só atinge as ações em defesa de interesses difusos e coletivos é considerar que não existe hipótese de a Lei n. 7.347/85 incidir sobre as ações em defesa de interesses individuais homogêneos, o que não pode ser aceito.

Partindo-se dessa premissa, temos que, nas ações em defesa de interesses individuais homogêneos propostas com base na Lei n. 7.347/85, a coisa julgada opera

\footnotetext{
${ }^{355}$ Rodolfo de Camargo Mancuso fala do absurdo a que essa situação pode levar: ações coletivas diversas pleiteando o reconhecimento de danos causados por um medicamento utilizado em vários Estados poderiam resultar em decisões conflitantes, de modo a que teríamos o reconhecimento de que a saúde humana difere de um lugar para outro: a saúde dos gaúchos usuários poderia estar sendo atingida, mas não a dos mineiros (Manual do consumidor em juízo. $3^{\mathrm{a}}$ ed. rev. atual. amp. São Paulo: Saraiva, 2001, p. 166). Não obstante, a situação não parece, considerada em si mesma (abstraída a repercussão entre os jurisdicionados), mais inconveniente do que qualquer outra em relação à qual sobrevenham sentenças conflitantes.

${ }^{356}$ V. capítulo 4, item 4.2.2.
} 
efeitos erga omnes, secundum eventum litis, porém restritos aos limites territoriais do órgão prolator. Se tal conclusão implica uma desvantagem, decorrente da restrição territorial, implica também um benefício, derivado do efeito secundum eventum litis, não estendido aos interesses individuais homogêneos pelo legislador no art. 103 do Código de Defesa do Consumidor em virtude da norma do art. 94, que possibilita a participação dos interessados na ação coletiva ${ }^{357}$, ainda que tal motivação pareça francamente insuficiente para parte da doutrina, como resultado da total ineficiência prática da comunicação ali prevista $^{358}$. Com a nova redação do art. 16, esse efeito foi estendido também aos interesses individuais homogêneos, desde que não decorrentes das relações de consumo.

O regime de extensão dos efeitos da coisa julgada secundum eventum litis sofre inúmeras críticas da doutrina, uma vez que impõe tratamento diferenciado ao réu do processo coletivo, que suporta os prejuízos de eventual sentença de procedência, mas não se beneficia em praticamente nada com a sentença de improcedência ${ }^{359}$.

Evidentemente, tudo depende de o tratamento diferenciado, imposto pelo legislador, não ofender ao princípio da isonomia justamente em virtude dos objetivos por ele buscados, ou seja, promover o acesso à justiça por meio do estímulo à tutela coletiva. Nesse sentido, conforme sustenta Antonio Gidi, a manutenção da possibilidade da via individual mostra-se uma vantagem ilusória, no mais das vezes, porque a tutela coletiva seria a única viável, na prática; além disso, de acordo com o mesmo autor, o desestímulo à participação dos interessados, provocado pela extensão da coisa julgada nas sentenças coletivas de improcedência para os interessados intervenientes, acaba vindo ao encontro da própria razão de ser da tutela coletiva, porque incentivar ampla participação equivaleria a promover o litisconsórcio multitudinário, uma das razões que pode tornar essa forma de

\footnotetext{
357 Cf. José Manoel Arruda Alvim et al. (Código do consumidor comentado. $2^{\mathrm{a}}$ ed. São Paulo: Editora Revista dos Tribunais, 1995, p. 468); também Vicente Greco Filho (In: OLIVEIRA, Juarez de (coord.) Comentários ao Código de Proteção ao Consumidor. São Paulo: Saraiva, 1991, p. 364).

${ }^{358}$ V. José Marcelo Menezes Vigliar, Alguns aspectos sobre a ineficácia do procedimento especial destinado aos interesses individuais homogêneos. In: MILARÉ, Édis. A ação civil pública após 20 anos: efetividade e desafios. São Paulo: Editora Revista dos Tribunais, 2005, p. 328.

${ }^{359}$ Nesse sentido, José Rogério Cruz e Tucci (Limites subjetivos da eficácia da sentença e da coisa julgada nas ações coletivas. In: Revista do Advogado da AASP, n. 89, dez. 2006, p. 75), apoiando-se também no entendimento de José Inácio Botelho de Mesquita. No mesmo sentido, Marcio Flávio Mafra Leal (Ações Coletivas: história, teoria e prática. Porto Alegre: Sergio Antonio Fabris Editor, 1998, p. 211). Para uma visão ampla sobre o desenvolvimento e as discussões envolvendo a coisa julgada secundum eventum litis, v. também Rodolfo de Camargo Mancuso (Ação popular. $5^{\mathrm{a}}$ ed. rev. atual. amp. São Paulo: Editora Revista dos Tribunais, 2003, p. 302-307).
} 
tutela jurisdicional não apenas conveniente como também indispensável ${ }^{360}$. Além disso, não é verdade que o réu vencido na ação coletiva sofre, em relação a cada interessado, o mesmo prejuízo que sofreria na ação individual proposta por este, sem poder obter, em contrapartida, equivalente benefício caso vença na jurisdição coletiva. Conforme justifica Ada Pelegrini Grinover, a ação de liquidação e execução da sentença genérica vai implicar em reabertura de contraditório pleno em relação à própria existência do dano individual, do nexo de causalidade entre sua conduta e esse dano e da extensão dos prejuízos sofridos, podendo resultar, naturalmente, em sentença que negue qualquer indenização em cada caso concreto $^{361}$.

Por outro lado, esse desestímulo à participação pessoal dos interessados não deixa de funcionar como contraponto ao tratamento desfavorável ao réu. Como os próprios críticos reconhecem, os interessados que intervierem na ação coletiva ficarão numa posição mais desfavorável do que ficariam se o regime da coisa julgada fosse o do Código de Processo Civil. De fato, considerando inexistir identidade de partes ou de pedido na ação coletiva e nas ações individuais, não haveria impedimento para qualquer interessado propor ação individual após o insucesso na ação coletiva, ainda que dela tivesse participado, se o regramento fosse o do processo civil comum, pois inexistiria coisa julgada a impedir esse ajuizamento, nos termos dos arts. 267 , inciso $\mathrm{V}^{362}$, e 301 , parágrafos $1^{\circ}, 2^{\circ}$ e $3^{\circ}$.

Outra questão relevante é a concomitância de uma ação coletiva versando interesses individuais homogêneos e uma ação individual pleiteando a mesma tutela, bem como a coexistência de duas ações coletivas. A litispendência tratada no art. 104 do Código de Defesa do Consumidor também rende polêmica em razão até mesmo de remissões a outros artigos que sugerem erro de redação.

É que o art. 104 afasta, expressamente, a litispendência entre ações individuais e ações coletivas em defesa de interesses difusos e coletivos, omitindo-se

${ }^{360}$ Coisa julgada e litispendência em ações coletivas. São Paulo: Saraiva, 1995, p. 147. V. também capítulo 4, item 4.1.

${ }^{361}$ Código brasileiro de defesa do consumidor comentado pelos autores do anteprojeto. $5^{\mathrm{a}}$ ed. rev. atual. amp. Rio de Janeiro: Forense Universitária, 1998, p. 712.

${ }^{362}$ V. José Inácio Botelho de Mesquita (A coisa julgada. São Paulo: Forense, 2006, p. 36). No mesmo sentido, José Rogério Cruz e Tucci (Limites subjetivos da eficácia da sentença e da coisa julgada nas ações coletivas. In: Revista do Advogado da AASP, n. 89, dez. 2006, 77). 
quanto aos interesses individuais homogêneos ("as ações coletivas, previstas nos incisos I e II do parágrafo único do art. 81, não induzem litispendência para as ações individuais ...”), para depois impor a obrigação de suspensão da ação individual para preservação do direito de beneficiar-se da coisa julgada formada nas ações coletivas em defesa de interesses coletivos e individuais homogêneos, ignorando os interesses difusos (“... mas os efeitos da coisa julgada erga omnes ou ultra partes a que aludem os incisos II e III do artigo anterior não beneficiarão os autores das ações individuais, se não for requerida sua suspensão ...”).

Vicente Greco Filho entende que ambas as remissões devem ser entendidas como sendo feitas exclusivamente aos interesses individuais homogêneos, porque só nesse caso elas apresentam utilidade ${ }^{363}$. O autor afirma que os interesses difusos ou coletivos diferem dos interesses individuais que possam ser buscados na via coletiva ou individual, de maneira que não haveria mesmo porque cogitar de litispendência. Chega a sustentar que num único caso pode haver litispendência, mesmo entendendo que o dispositivo só se refere a interesses individuais homogêneos: quando houver uma ação coletiva e todos os interessados ingressaram com ações individuais, pois nesse caso a tutela coletiva seria inútil.

Ada Pellegrini Grinover sustenta que as remissões devem ser corrigidas apenas incluindo-se, na obrigação de suspensão da ação individual para poder beneficiar-se dos efeitos da coisa julgada, a hipótese de sentença versando interesses difusos, mesmo entendendo pela exclusão, nesse caso, dos interesses individuais homogêneos ${ }^{364}$. Explica a autora que, com ou sem a referência aos interesses individuais homogêneos, a interpretação do dispositivo não muda. Aduz que pode haver continência entre os pedidos individuais e o coletivo envolvendo interesses individuais homogêneos, devendo as causas ser reunidas nos termos do art. 105 do Código de Processo Civil.

Rodolfo de Camargo Mancuso também entende que a remissão correta seria aquela excluindo os interesses individuais homogêneos e incluindo os interesses

\footnotetext{
${ }^{363}$ In: OLIVEIRA, Juarez de (coord.), Comentários ao Código de Proteção ao Consumidor. São Paulo: Saraiva, 1991, p. 366.

${ }^{364}$ Código brasileiro de defesa do consumidor comentado pelos autores do anteprojeto. $5^{\mathrm{a}}$ ed. rev. atual. amp. Rio de Janeiro: Forense Universitária, 1998, p. 733.
} 
difusos $^{365}$. Já Antonio Gidi discorda, defendendo que ambas as remissões deveriam ser aos três tipos de interesses disciplinados no Código de Defesa do Consumidor ${ }^{366}$, posição compartilhada por Arruda Alvim ${ }^{367}$.

Em primeiro lugar, o objetivo maior do art. 104 não é o de afastar litispendência entre a ação coletiva e as ações individuais, mesmo na hipótese de ação coletiva em defesa de interesses individuais, como parece à primeira vista, tendo em conta a parte inicial do dispositivo. É que não há mesmo como considerar a existência de litispendência entre ação coletiva e individual se o pedido é diferente não apenas subjetivamente (numa ação o pedido abrange uma coletividade indeterminada, noutra, uma ou algumas pessoas determinadas), mas também objetivamente (numa ação pede-se a condenação à reparação de interesses difusos, coletivos ou uma condenação genérica, noutra pede-se uma condenação específica), havendo, no máximo, identidade de causas de pedir.

O verdadeiro objetivo é a regulação dos limites do exercício do direito ao transporte da coisa julgada in utilibus para as ações individuais, ou seja, quando esse direito estará assegurado a cada interessado e quando não mais poderá ser exercido. Por outras palavras, o art. 104 só confirma que a coexistência de ações individuais concomitantes à ação coletiva é sempre permitida ${ }^{368}$; já o transporte da coisa julgada, fica estipulado que nem sempre será possível.

Sob esse ponto de vista, é mais consistente o posicionamento de que as remissões do art. 104 devem ser entendidas como englobando todas as espécies de interesses transindividuais, isto é, mencionando os incisos I, II e III tanto do art. 81 como do art. 103 do Código de Defesa do Consumidor. Inexiste litispendência mesmo na hipótese de ação coletiva em defesa de interesses individuais homogêneos e ações individuais movidas por todos os interessados, simplesmente porque não há amparo legal para assim ser considerado, descartado considerar a falta de utilidade, uma vez não ser

\footnotetext{
${ }^{365}$ Defesa do Consumidor. Reflexões acerca da eventual concomitância de ações coletivas e individuais. In: Revista dos Tribunais, vol. 676, São Paulo, Editora Revista dos Tribunais, fev. 1992, p. 36.

${ }^{366}$ Coisa julgada e litispendência em ações coletivas. São Paulo: Saraiva, 1995, p. 193.

${ }^{367}$ Código do consumidor comentado. $2^{\mathrm{a}}$ ed. São Paulo: Editora Revista dos Tribunais, 1995, p. 487.

${ }^{368}$ Nesse sentido, José Manoel Arruda Alvim, Código do consumidor comentado. $2^{\mathrm{a}}$ ed. São Paulo: Editora Revista dos Tribunais, 1995, p. 489.
} 
possível aferir qual das vias será mais rápida, qual poderá ser inviabilizada por uma sentença terminativa ou qual poderá ser obstada por vicissitudes do processo (perícias complexas, provas demoradas etc.). Além disso, como vimos, a soma dos pedidos individuais não é igual ao pedido coletivo ${ }^{369}$, de maneira que também não se pode cogitar de continência, conforme também defende Antonio Gidi ${ }^{370}$.

Já quanto ao transporte in utilibus, é evidente que a ação coletiva em defesa de interesses difusos não pode ficar de fora dessa regulação, uma vez que os mesmos fatos podem ensejar a violação geradora de interesses individuais. Além disso, não há razão para que tais interesses mereçam tratamento jurídico diverso do dedicado aos interesses coletivos em sentido estrito e individuais homogêneos.

Ao requerer a suspensão da sua ação individual, o interessado assegura o direito de utilizar-se do transporte da coisa julgada favorável da sentença na ação coletiva, devendo fazê-lo no prazo de trinta dias a partir da ciência do ajuizamento $\operatorname{desta}^{371}$. Se requerer tal suspensão para atender ao convite de intervenção na ação coletiva, previsto no art. 94 do Código, o interessado ficará vinculado aos efeitos da coisa julgada na sua ação individual, caso a sentença coletiva seja desfavorável. A suspensão, no caso de ação coletiva para tutela de interesses individuais homogêneos, será por prazo indeterminado, pois a lei não prevê limitação ${ }^{372}$.

Tratando-se de litispendência entre ações coletivas, pode haver, nesse caso sim, identidade quanto aos seus elementos constitutivos. E a parte a ser considerada,

\footnotetext{
${ }^{369}$ V. capítulo 1, item 1.5.

${ }^{370} \mathrm{O}$ autor lembra que no litisconsórcio, sim, é possível dizer que o pedido dos autores litisconsorciados é igual à soma dos pedidos das ações individuais (Coisa julgada e litispendência em ações coletivas. São Paulo: Saraiva, 1995, p. 210). Também descartando a identidade de ações entre ação coletiva e individual, por possuírem pedidos diversos, v. Ibraim Rocha (Litisconsórcio, efeitos da sentença e coisa julgada na tutela coletiva. Rio de Janeiro: Forense, 2002, p. 154).

${ }^{371}$ É o que mais se aproxima, no direito brasileiro, ao right to opt out do sistema norte-americano, mas com ele não se confunde: lá, o interessado é intimado para exercer o direito de se excluir da coletividade que vai litigar em juízo e submeter-se à coisa julgada coletiva daí resultante; aqui, o interessado é intimado da existência da ação coletiva para exercer o direito de preservar o benefício de extensão ao seu processo individual da coisa julgada a ser formada no processo coletivo, em troca da paralisação do primeiro (v. capítulo 4, item 4.2.1).

${ }^{372}$ Em sentido contrário, Ada Pellegrini Grinover, sustentando que, se não houver a reunião das ações em razão da continência, a suspensão que incidirá será compulsória, em decorrência de prejudicialidade, por força do art. 265, inciso IV, alínea "a", do Código de Processo Civil, não podendo ultrapassar um ano (Código brasileiro de defesa do consumidor comentado pelos autores do anteprojeto. $5^{\mathrm{a}}$ ed. rev. atual. amp. Rio de Janeiro: Forense Universitária, 1998, p. 737-738).
} 
naturalmente, não é o autor coletivo, mero representante, mas a coletividade substituída; por outras palavras, o que importa é a qualidade com a qual o autor coletivo está agindo, de acordo com amplo entendimento doutrinário ${ }^{373}$. Pouco importa também que a propositura tenha ocorrido com a denominação de ação civil pública ou ação coletiva.

Seja como for, a questão perdeu relevância, relativamente, com a limitação territorial da coisa julgada e a limitação da abrangência da sentença na ação proposta por associação (arts. $2^{\circ}$ e $2^{\circ}$-A da Lei n. 9.494/97, já comentados). Acolhendo-se tais limitações territoriais, seria não apenas cabível mas também necessária a propositura de diversas ações coletivas, desde que em foros diversos, para tutelar os interesses individuais homogêneos de todos os que sofreram dano, tantos quantos forem necessários para abranger todos os domicílios destes ${ }^{374}$.

5.3.2 - Estudo de caso: coisa julgada e tutela coletiva

No julgamento do Recurso Especial n. 411.529-SP ${ }^{375}$, a discussão envolveu a incidência do art. 16 da Lei da Ação Civil Pública, na nova redação dada pelo art. $2^{\circ}$ da Lei n. 9.494/97, para disciplinar ação coletiva para tutela de interesses individuais homogêneos de consumidores. Alega o recorrente que o acórdão recorrido violou o art. 103, inciso III, do Código de Defesa do Consumidor.

No voto condutor do acórdão foi consignado que, após a edição do Código de Defesa do Consumidor, "a ordem jurídica brasileira passou a contar com uma disciplina específica, independente da disciplina da ação civil pública, para a tutela dos direitos transindividuais dos consumidores em juízo e, dentro dessa disciplina, normas ainda mais específicas regulando a tutela de direitos individuais homogêneos". Assim, continua, "resulta que o ordenamento jurídico brasileiro contém: (i) uma disciplina geral, a ser aplicada para a tutela dos interesses relativos ao meio ambiente, bens e direitos de

\footnotetext{
${ }^{373}$ Nesse sentido, Luiz Paulo da Silva Araújo Filho (Ações coletivas: a tutela jurisdicional dos direitos individuais homogêneos. Rio de Janeiro: Forense, 2000, p. 161) e Antonio Gidi (Coisa julgada e litispendência em ações coletivas. São Paulo: Saraiva, 1995, p. 219).

${ }^{374}$ Existe entendimento do Superior Tribunal de Justiça no sentido de que os limites territoriais aos quais ficaria restrita a extensão da eficácia da coisa julgada seriam aqueles do tribunal competente para julgar o recurso ordinário (REsp n. 293407, DJ de 07/04/2003, p. 290, Relator Min. Barros Monteiro; REsp n. 253589, DJ de 18/03/2002, p. 255, Relator Min. Ruy Rosado de Aguiar). Sobre o tema, v. item 5.3.2.

375 Acórdão de 24/06/2008.
} 
valor artístico, estético e afins, infração à ordem econômica ou urbanística e demais interesses difusos ou coletivos (Lei $n^{o} 7.347 / 85$, art. $1^{o}$ e seus incisos, excetuado o inciso II); (ii) uma disciplina específica para a tutela de direitos e interesses difusos e coletivos ligados a relações de consumo, cuja regulação se dá pelos arts. 81 a 90 do CDC e, subsidiariamente, pelos dispositivos da LACP; (iii) uma disciplina ainda mais específica, contida nos arts. 91 a 100 do CDC, aplicável somente aos direitos individuais homogêneos". Por essa razão, o art. 16 não se aplica às ações envolvendo consumidores.

Subsidiariamente, sustenta-se no acórdão que, mesmo entendendo-se aplicáveis às ações de consumidores, os efeitos do art. 16 só alcançam à tutela de direitos difusos e coletivos de consumidores, jamais os direitos individuais homogêneos, já que somente os incisos I e II do art. 103, que tratam de interesses difusos e coletivos, preveem a coisa julgada erga omnes. Mais uma vez de forma subsidiária, aduz-se no julgado que, ainda na hipótese de considerar-se possível aplicar o art. 16 à tutela de interesses individuais de consumidores, tal restrição consistiria não em deixar de submeter todos os interessados aos efeitos da sentença, mas apenas em não incidir sobre a sentença a imutabilidade desses efeitos senão dentro dos limites territoriais do órgão prolator, conforme lição de Liebman. Assim, os efeitos da sentença, principais (comando do julgado) e secundários (criação do título judicial), estendem-se a todos, sem qualquer limitação.

Antes de adentrar nos fundamentos do acórdão, convém assentar entendimento sobre a aplicação do art. 16 da Lei n. 7.347/85. É insustentável a tese no sentido de que a alteração desse dispositivo pela Lei n. 9.494/97 tenha sido inócua porque ele já estaria revogado pelo art. 103 do Código de Defesa do Consumidor. Em primeiro lugar, porque não houve revogação: o art. 103 é norma específica, enquadrando-se na hipótese do parágrafo $2^{\circ}$ do art. $2^{\circ}$ da Lei de Introdução ao Código Civil (DL n. 4.657/42), ou seja, "a lei nova, que estabeleça disposições gerais ou especiais a par das já existentes, não revoga nem modifica a lei anterior". Em segundo lugar, porque, ainda que isso tivesse sucedido, a alteração só poderia ser considerada lei nova, surtindo efeitos no âmbito de aplicação do diploma legal no qual está inserido.

Também o entendimento de que os limites territoriais do órgão prolator seriam os do tribunal julgador do recurso ordinário ou todo o país, no caso de recurso 
especial ou extraordinário ${ }^{376}$, tornando inócua a restrição, é inaceitável. De um lado, porque o dispositivo estabelece claramente que os limites a que alude são os do órgão prolator da sentença, imodificáveis pelo mero efeito devolutivo de eventual recurso. De outro lado, seria mesmo muito estranho que os limites subjetivos da coisa julgada a ser formada fossem sendo alterados conforme o processo fosse mudando de instância, numa espécie de efeito "ampliativo" do recurso. Por fim, a exegese legal de que, ao chegar à via extraordinária, não haveria mais qualquer limitação, consiste em escolher a interpretação que confere a mínima efetividade ao texto da lei, contrária aos ensinamentos hermenêuticos mais elementares ${ }^{377}$.

Comecemos pelo final da fundamentação do acórdão. É perfeito o entendimento de que o art. 16 não trata dos efeitos da sentença, isto é, da sua eficácia (natural, na concepção de Liebman ${ }^{378}$ ), ou da extensão subjetiva desses efeitos. O art. 16 trata dos limites subjetivos da coisa julgada, quer dizer, da extensão da eficácia da coisa julgada, ou da imutabilidade dos efeitos da sentença ${ }^{379}$. Sendo assim, o art. 16 estipula que todos os que estiverem fora dos limites territoriais do órgão prolator poderão questionar a decisão contida na sentença, ainda que venham a subordinar-se aos seus efeitos. Resta saber se uma sentença assim, desacobertada da autoridade da coisa julgada, será útil para os interessados domiciliados fora dos limites apontados no dispositivo.

Já a afirmação de que o art. 16 aplica-se apenas aos interesses difusos e coletivos dos consumidores, porque a Lei da Ação Civil Pública só tutela direitos difusos e coletivos e porque dispõe sobre julgamento de improcedência por falta de provas, carece de amparo na legislação apontada. O art. 90 do Código de Defesa do Consumidor é claro: “aplicam-se às ações previstas neste título" (título III, da defesa do consumidor em juízo, cujo art. 81 autoriza a defesa em juízo dos consumidores individualmente ou a título coletivo quando se tratar de interesses difusos, coletivos e individuais homogêneos) "as normas do Código de Processo Civil e da Lei $n^{\circ}$ 7.347, de 24 de julho de 1985”. Da

\footnotetext{
${ }^{376}$ V. nota 249.

377 "Prefira-se a inteligência dos textos que torne viável o seu objeto, ao invés da que os reduza à inutilidade" (Digesto, liv. 34, tit. 5, frag. 12, apud Carlos Maximiliano, Hermenêutica e aplicação do direito. Rio de Janeiro: Forense, 1998, p. 249).

${ }^{378}$ Cf. Cândido Rangel Dinamarco (Instituições de direito processual civil - vol. III. $4^{\mathrm{a}}$ ed. rev. atual. São Paulo: Malheiros, 2004, p. 207).

${ }^{379}$ Nesse sentido, Antonio Gidi, Coisa julgada e litispendência em ações coletivas. São Paulo: Saraiva, 1995 , p. 107.
} 
mesma forma, segundo o art. 21 da Lei n. 7.347/90, "aplicam-se à defesa dos direitos $e$ interesses difusos, coletivos e individuais, no que for cabível, os dispositivos do Título III da lei que instituiu o Código de Defesa do Consumidor". Portanto, a Lei da Ação Civil Pública também tutela interesses individuais homogêneos. Ao mesmo tempo, pouco importa que haja coincidência parcial entre os regimes da coisa julgada em ambos os diplomas legais; diante das diferenças inconciliáveis, prevalecerá a previsão do Código quando se tratar de consumidores, preponderando a Lei da Ação Civil Pública em caso contrário.

A conclusão é que o art. 16 não se aplica a quaisquer interesses dos consumidores, sejam difusos, coletivos ou individuais homogêneos, mas não pelos motivos apontados, e sim porque há regulação própria no Código de Defesa do Consumidor, incompatível e prevalecente.

Esse mesmo entendimento, não obstante, é apontado na parte inicial da fundamentação, quando se afirma que o art. 16 da Lei n. 7.347/85 não se aplica ao caso porque essa aplicação não pode contrariar as disposições do Código de Defesa do Consumidor, cujo art. 103 e parágrafos contêm disciplina expressa sem qualquer limitação territorial. Conclui que o art. 16 aplica-se a outros interesses transindividuais que não o de consumidores, coincidindo com o entendimento demonstrado acima.

Também o panorama da legislação de tutela dos interesses transindividuais não encontra suporte na integração entre as Leis n. 7.347/85 e 8.078/90. Não há três disciplinas legais, há uma disciplina geral, da Lei da Ação Civil Pública, e outra específica, do Código, válida para os interesses dos consumidores, mas que incide na tutela de outros interesses transindividuais, incluindo individuais homogêneos, sempre que não contrariar a Lei n.7.347/85.

Por fim, a decisão quanto à impossibilidade de restrição dos efeitos da sentença com base no art. $2^{\circ}$-A da Lei n. 9.494/97, que efetivamente trata da eficácia da sentença, não da imutabilidade do seu comando, encontra-se acertadamente fundamentada. Tendo o pedido da autora, então recorrente, sido dirigido a todos os que fossem titulares de caderneta de poupança, não apenas aos seus associados, não há incidência da norma, que aplica-se apenas à ação movida por associação em defesa exclusivamente dos direitos e interesses dos seus associados. Não é o caso daqueles autos. 


\section{4 - A execução}

\subsection{1 - Aspectos Polêmicos}

A liquidação e a execução da sentença genérica encontram previsão nos arts. 97 a 100 do Código de Defesa do Consumidor. Ao contrário do que, em princípio, possa parecer, os arts. 97 e 98 não tratam, respectivamente, da liquidação e execução individual e coletiva. Ambos tratam da execução em caráter geral, regulando aspectos das duas formas pelas quais ela pode ocorrer.

Na primeira parte do art. 97, quando é atribuída legitimidade às vítimas e sucessores, está-se falando do tratamento individual da sentença genérica; na parte final, quando recebem legitimação os mesmos legitimados para a propositura da ação coletiva, de acordo com o art. 82 (Ministério Público, órgãos públicos e associações), o tema é o tratamento coletivo ${ }^{380}$. No primeiro caso, temos legitimação ordinária; no segundo, legitimação extraordinária ${ }^{381}$.

Parte da doutrina entende versar o art. 97 somente sobre liquidação e execução individuais (assim como o art. 98 trataria exclusivamente sobre execução coletiva); nesse caso, a autorização legal parece conformar-se com outorga de poderes de representação, por meio da qual os legitimados do art. 82 agiriam em nome e no interesse das vítimas e sucessores ${ }^{382}$. Porém, desnecessário seria conceder poderes de representação

\footnotetext{
${ }^{380}$ Para José Manoel Arruda Alvim, “a legitimidade dos primeiros é preferencial, e, correlatamente, a dos do art. 82 é, em certo sentido, subsidiária e a liquidação a que possam proceder diz respeito ao que consta do art. 100" (Código do consumidor comentado. $2^{\mathrm{a}}$ ed. São Paulo: Editora Revista dos Tribunais, 1995, p. 435). No entanto, as associações, excepcionalmente, podem proceder à liquidação individual valendo-se dos poderes conferidos pelo art. $5^{\circ}$, inciso XXI.

381 Nesse sentido, Rodolfo de Camargo Mancuso (In: OLIVEIRA, Juarez de (coord.), Comentários ao Código de Proteção ao Consumidor. São Paulo: Saraiva, 1991, p. 336) e Nelson Nery Júnior e Rosa Maria Andrade Nery (Código de processo civil comentado e legislação extravagante. $4^{\mathrm{a}}$ ed. rev. amp. São Paulo: Editora Revista dos Tribunais, 1999, p. 1.877).

382 Entendendo tratar-se de representação, v. Ada Pellegrini Grinover (Código brasileiro de defesa do consumidor comentado pelos autores do anteprojeto. $5^{\mathrm{a}}$ ed. rev. atual. amp. Rio de Janeiro: Forense Universitária, 1998, p. 691), Flavio LuizYarshell (Observações a propósito da liquidação na tutela de direitos individuais homogêneos. In: WAMBIER, Teresa Arruda Alvim (coord.). Repertório de Jurisprudência e Doutrina - Atualidades sobre liquidação de sentença. São Paulo: Editora Revista dos Tribunais, 1997, p. 159) e Paulo Henrique dos Santos Lucon e Érica Barbosa e Silva (Análise crítica da liquidação e execução na tutela coletiva, in LUCON, Paulo Henrique dos Santos (org.). Tutela coletiva. São Paulo: Atlas, 2006, p. 178).
} 
às associações, que já o receberam da Constituição Federal (art. $5^{\circ}$, inciso XXI) ${ }^{383}$. Quanto ao Ministério Público e órgãos públicos, não se vislumbra circunstância na qual tais entes teriam algum interesse em promover liquidação e execução específicas em favor de particulares, ainda mais mediante representação. Em consequência, é certo não possuir o Ministério Público legitimidade para promover o tratamento individualizado da sentença genérica, mas não porque ele não tem poderes para agir em nome próprio em favor das vítimas e sucessores e sim porque, nessa hipótese, não se trata de defesa de interesses sociais ou individuais indisponíveis ${ }^{384}$.

Também há divergência sobre a competência para o julgamento da liquidação e execução da sentença genérica, tendo em vista o veto ao parágrafo único do art. 97 do Código de Defesa do Consumidor, que autorizava o ajuizamento da execução também no juízo do domicílio do liquidante, concorrentemente com aquele do processo de conhecimento. Rodolfo de Camargo Mancuso ${ }^{385}$ e Arruda Alvim ${ }^{386}$ entendem que, com o veto, impossível cogitar de competência do juízo do domicílio do liquidante, de maneira que a competência única é aquela resultante do critério funcional por conexão sucessiva, isto é, o foro da ação de conhecimento. Para Ada Pellegrini Grinover ${ }^{387}$ e Nelson Nery Júnior $^{388}$ o veto foi inócuo, uma vez que permaneceu o disposto no inciso I do parágrafo $2^{\circ}$ do art. 98, prevendo a competência para execução do juízo "da liquidação ou o da ação condenatória", bem como a norma do inciso I do art. 101, autorizando a propositura da ação de responsabilidade civil do fornecedor no domicílio do autor, podendo ser aplicada por analogia.

\footnotetext{
${ }^{383} \mathrm{~V}$. item 4.4.2, em especial a nota 293.

384 Também entendendo que falta legitimidade para o Ministério Público propor a liquidação e execuçãoindividuais por ser atividade incompatível com suas missões constitucionais, Elton Venturi (Execução da tutela coletiva. São Paulo: Malheiros, 2000, p. 132).

385 In: OLIVEIRA, Juarez de (coord.), Comentários ao Código de Proteção ao Consumidor. São Paulo: Saraiva, 1991, p. 339.

${ }^{386}$ Código do consumidor comentado. $2^{\mathrm{a}}$ ed. São Paulo: Editora Revista dos Tribunais, 1995, p. 442.

${ }^{387}$ Código brasileiro de defesa do consumidor comentado pelos autores do anteprojeto. $5^{\mathrm{a}} \mathrm{ed}$. rev. atual. amp. Rio de Janeiro: Forense Universitária, 1998, p. 692-693.

${ }^{388}$ Código de processo civil comentado e legislação extravagante. $7^{\mathrm{a}}$ ed. rev. amp. São Paulo: Editora Revista dos Tribunais, 2003, p. 1.877.
} 
Todavia, não há como considerar inútil o veto ${ }^{389}$. Insustentável deixar sequer de considerar a exposição de motivos correspondente ${ }^{390}$ : se o conteúdo da exposição de motivos do projeto de lei apresenta, indiscutivelmente, valor interpretativo dos dispositivos que vierem a constituir direito posto, inegável que não pode ser ignorada a justificação do veto, produzida por órgão igualmente dotado de legitimidade constitucional para participar do processo legislativo. Além disso, o inciso I do parágrafo $2^{\circ}$ do art. 98 sequer fala em foro do domicílio do liquidante, mas em foro da liquidação, que, se for o mesmo da ação de conhecimento, não abre mesmo nenhuma possibilidade de escolha. Ora, com o veto, não há qualquer autorização para promover a liquidação no foro do domicílio do liquidante.

Não é verdade que a lei não possa conter dispositivos inúteis; ao contrário, frequentemente contém. A regra hermenêutica consiste na proibição de presunção da inutilidade de palavras e frases no texto legal. Por outras palavras, a operação interpretativa não pode iniciar-se com a atribuição de significado nulo para qualquer parte do texto a ser interpretado, mas pode perfeitamente terminar com esse resultado ${ }^{391}$.

No caso, não há qualquer dúvida sobre os motivos pelos quais a previsão dupla quanto à competência para a execução restou inútil: o veto. Portanto, não há qualquer motivo para sair buscando na lei uma explicação para dispositivo cuja utilidade todos sabem como e por qual razão foi retirada. A utilização da analogia para aplicar a norma do inciso I do art. 101 é ainda mais insustentável. A analogia é processo de integração do ordenamento; só cabe quando há lacuna. No caso da fixação de competência para a liquidação da sentença genérica não cabe qualquer analogia porque não há nenhuma lacuna: a aplicação subsidiária do Código de Processo Civil está expressamente prevista no

\footnotetext{
${ }^{389}$ Como sustenta Ada Pellegrini Grinover, Código brasileiro de defesa do consumidor comentado pelos autores do anteprojeto. $5^{\mathrm{a}}$ ed. rev. atual. amp. Rio de Janeiro: Forense Universitária, 1998, p. 693.

${ }^{390}$ Conforme sustenta Elton Venturi (Execução da tutela coletiva. São Paulo: Malheiros, 2000, p. 134).

${ }^{391}$ Sobre o tema, ensina Carlos Maximiliano que "o preceito não é absoluto. Se de um trecho se não colige sentido apreciável para o caso, ou transparece a evidência de que as palavras foram insertas por inadvertência ou engano, não se apega o julgador à letra morta, inclina-se para o que decorre do emprego de outros recursos aptos a dar o verdadeiro alcance da norma (...) bem avisados, os norte-americanos formulam a regra de Hermenêutica nestes termos: 'deve-se atribuir, quando for possível, algum efeito a toda palavra, cláusula, ou sentença' (...) não se presume a existência de expressões supérfluas; em regra, supõese que leis e contratos foram redigidos com atenção e esmero; de sorte que traduzam o objetivo dos seus autores. Todavia é possível, e não muito raro, suceder o contrário; e na dúvida entre a letra e o espírito, prevalece o último" (Hermenêutica e aplicação do direito. Rio de Janeiro: Forense, 1998, p. 251).
} 
Código de Defesa do Consumidor (art. 90), cuja regra geral fixa a competência para o juízo que decidiu a causa em primeiro grau de jurisdição (inciso II do art. 575) ${ }^{392}$.

O mesmo parágrafo único também dispunha que a liquidação seria por artigos. O objetivo do veto, de acordo com a exposição de motivos, foi apenas de impedir a fixação de competência concorrente, não de alterar a forma pela qual a liquidação seria processada, cuja menção acabou vetada por força da norma constitucional que impede o veto de parte de artigo, parágrafo, inciso ou alínea (parágrafo $2^{\circ}$ do art. 66). Assim, nada impede que a interpretação da legislação aplicável resulte na conclusão de que a forma cabível de liquidação é por artigos.

E é isso que resulta também da aplicação subsidiária do Código de Processo Civil, nos termos do art. 90 do Código de Defesa do Consumidor. Tratando-se de liquidação na qual, como regra, será necessária a alegação e prova de fatos novos, não tratados na fase inicial, consistentes no dano sofrido, sua quantificação e o nexo de causalidade entre o ato lesivo praticado pelo devedor e esse dano, aplica-se o art. 475-E e 475-F do estatuto processual civil, ou seja, a forma será mesmo por artigos ${ }^{393}$. Excepcionalmente, de acordo com as peculiaridades do caso concreto, poderá haver liquidação por cálculo aritmético apresentado pelo credor (por exemplo, quando não houver questionamento sobre a qualidade do credor e a sentença genérica trouxer fórmula matemática para apuração dos danos sofridos) ou por arbitramento (por exemplo, quando houver necessidade de perícia médica para quantificar os danos provocados a determinado liquidante).

\footnotetext{
${ }^{392}$ Nesse sentido, José Manoel Arruda Alvim, Código do consumidor comentado. $2^{\mathrm{a}}$ ed. São Paulo: Editora Revista dos Tribunais, 1995, p. 442). Em sentido contrário, admitindo o ajuizamento da execução no foro do domicílio do autor, Rodolfo de Camargo Mancuso (Manual do consumidor em juízo. $3^{\mathrm{a}}$ ed. rev. atual. amp. São Paulo: Saraiva, 2001, p. 194) e Elton Venturi (Execução da tutela coletiva. São Paulo: Malheiros, 2000, p. 152).

${ }^{393}$ Nesse sentido, Rodolfo de Camargo Mancuso (In: OLIVEIRA, Juarez de (coord.), Comentários ao Código de Proteção ao Consumidor. São Paulo: Saraiva, 1991, p. 336) e Ada Pellegrini Grinover (Código brasileiro de defesa do consumidor comentado pelos autores do anteprojeto. $5^{\mathrm{a}}$ ed. rev. atual. amp. Rio de Janeiro: Forense Universitária, 1998, p. 692).
} 
5.4.2 - Estudo de caso: a liquidação da sentença coletiva

O Recurso Especial n. 880.385-SP ${ }^{394}$ foi interposto com o objetivo de reforma da decisão que entendeu pela legitimidade da associação autora para também proceder à execução provisória do julgado (já que pendentes recursos extraordinário e especial, impugnando a decisão pela extensão erga omnes dos limites subjetivos da coisa julgada), desnecessidade de liquidação prévia e cabimento de penhora de dinheiro, tratando-se de instituição financeira com numerário disponível em caixa. A ação civil pública visava a condenação do ora recorrente a pagar aos associados do autor diferenças de correção monetária sobre saldos de cadernetas de poupança.

A fundamentação começa pela delimitação do pedido recursal e caracterização da tutela de que se trata, de execução provisória de sentença que tutela interesses individuais homogêneos de poupadores. A sentença, segundo o acórdão, "envolve um total de $R \$ 815.562,92$, mas, entre as pessoas representadas pelo exeqüente, há algumas que detêm contas com crédito inferior a $R \$ 100,00$ ".

Afirma não se sustentar o argumento de que a execução coletiva só poderia ocorrer de acordo com o art. 100 do Código de Defesa do Consumidor. É evidente que o estatuto consumerista prevê duas formas de execução coletiva, quer dizer, uma referida aos prejuízos causados e destinada ao fundo de direitos difusos, conforme o art. 100, outra relativa aos prejuízos sofridos e destinada aos lesados, de acordo com o art. 98, caput e parágrafo $1^{\circ}$. Assim, correta a fundamentação no sentido de que não se trata da execução em favor do fundo de direitos difusos, restando saber se a associação pode representar seus filiados nessa fase processual.

O entendimento expresso no acórdão é que a execução é promovida por associações por meio de representação, a depender de autorização expressa, nos termos do art. 97 do Código de Defesa do Consumidor, em consonância com a previsão do inciso XXI do art. $5^{\circ}$ da Constituição Federal ("as entidades associativas, quando expressamente autorizadas, têm legitimidade para representar seus filiados judicial ou

\footnotetext{
${ }^{394}$ Acórdão de 02/09/2008.
} 
extrajudicialmente ${ }^{, 395}$ ). Conclui daí que a existência de autorização, qualquer que seja a sua forma, constitui matéria fática, vedada na via extraordinária.

Porém, como visto anteriormente ${ }^{396}$, não se trata de representação, mas de legitimação extraordinária. Sendo assim, tendo recebido a outorga legal de legitimidade para propor, em nome próprio, a execução coletiva em favor de seus associados, a questão é exclusivamente de direito e resolve-se em favor da recorrida. Naturalmente que essa legitimidade, que se estende mesmo a outras associações que não a responsável pelo ajuizamento, diante de seu caráter concorrente, fica restrita à execução em favor dos próprios associados, já que a atribuição de legitimação para agir é condicionada aos interesses próprios de cada legitimado ${ }^{397}$.

Quanto à forma de liquidação, correta a fundamentação ao admitir, no caso, a liquidação mediante simples cálculo aritmético ${ }^{398}$, uma vez que a sentença não exige processo de liquidação para comprovação de condição de vítimas nem extensão dos danos. Considerando que o autor juntou comprovação suficiente da identidade dos lesados e da extensão dos danos, representada pelos extratos da época do depósito insuficiente de rendimentos, o réu não necessita qualquer outra informação para efetuar o cumprimento da sentença, sendo correto que até mesmo seja o autor dispensado da juntada de memórias de cálculos, que podem ser efetivadas, com maior vantagem e facilidade, pelo próprio réu. Ademais, o acórdão ressalvou que o executado poderá, caso queira, impugnar a execução contestando a documentação acostada, na via dos embargos.

Finalmente, quanto à penhora sobre numerário disponível nos caixas do banco executado, cabível a fundamentação pela improcedência da impugnação no sentido da substituição por títulos públicos. O procedimento da execução é o do Código de Processo Civil, aplicado subsidiariamente por força do art. 90 do Código de Defesa do Consumidor. Nesse caso, tem plena aplicação a norma do art. 655 do estatuto processual, inadmissível a invocação do art. 620 para justificar a inversão da ordem legal de

\footnotetext{
${ }^{395}$ V. capítulo 4, item 4.4.2.

${ }^{396}$ V. capítulo 5, item 5.4.1.

${ }^{397}$ Por essa razão, está vedado ao Ministério Público e aos órgãos públicos promover execução que não seja coletiva e em favor do fundo de defesa dos direitos difusos (art. 100 do Código de Defesa do Consumidor).

${ }^{398}$ Na época, art. 604 do Código de Processo Civil; hoje, art. 475-B.
} 
preferência dos bens sobre os quais será efetivada a penhora, já que não se trata de meios igualmente passíveis de incidência da constrição, mas desequiparados pela própria lei. 


\section{CONSIDERAÇÕES CONCLUSIVAS}

1 - Por maior que seja a semelhança conceitual, interesse é nomenclatura melhor ajustada ao objeto da tutela coletiva do que direito, por referir-se a posições jurídicas tradicionalmente descuradas, em virtude da ausência de um titular a quem pudessem ser atribuídas para fins de defesa judicial. Além disso, trata-se de termo consagrado na prática e utilizado pelos textos normativos referentes a essa matéria, a começar da Constituição Federal. Os interesses transindividuais sofreram maiores vicissitudes com a evolução das sociedades do que os individuais, gerando problemas de solução difícil até hoje, como a representação em juízo de grupos numerosos e diversificados. Desses interesses referidos a uma coletividade, os denominados difusos e os coletivos em sentido estrito são coletivos na sua essência, enquanto que os individuais homogêneos o são pela circunstância de admitirem defesa em grupo, ainda que a classificação dessas posições jurídicas seja polêmica e influenciada pela necessidade da sua tutela em forma coletiva.

2 - Os interesses individuais homogêneos são individuais na sua essência e coletivos quando comparados entre si, mostrando-se divisíveis, apropriáveis individualmente, disponíveis na perspectiva individual, transmissíveis, representados em juízo pelo próprio titular, episodicamente transindividuais, subjetivamente determinados, diretamente reparáveis, decorrentes de uma origem comum e referidos a uma só ordem de obrigados. Considerando que não existe um interesse individual homogêneo isoladamente considerado, mas sempre tomado em referência a outros com os quais apresente homogeneidade, esses interesses apresentam também uma dimensão coletiva, porque se referem a uma coletividade, são lesados mediante um único ato, ainda que desdobrado no tempo ou no espaço, cujo resultado é maior do que a soma das lesões individuais, exige uma resposta estatal mais eficaz e complexa e está conectado com os demais interesses essencialmente coletivos. É essa face coletiva que os torna suscetíveis de receberem tutela judicial na jurisdição coletiva, não a mera vontade do legislador, e é em função dela que apresentam a nota da relevância social e, nessa perspectiva, da indisponibilidade.

3 - A sociedade moderna, marcada por relações jurídicas massificadas, gera relações de troca e consumo de massa das quais resultam violações de direitos e litígios também de massa. Esse desenvolvimento social propiciou não apenas a revelação, mas a proliferação dos interesses individuais homogêneos. Também representou um paradoxo, pois primeiro 
separou os indivíduos por meio da diferenciação do seu modo de vida e depois estimulou a sua união para melhor defender os mesmos interesses que fez surgir. No Brasil, a esse fenômeno somaram-se os reflexos do movimento mundial de reconhecimento dos direitos humanos de terceira geração e o despertar da consciência de cidadania resultante da redemocratização, provocando forte demanda por justiça. Essas tendências têm provocado um aumento do volume processual que pode não corresponder a um efetivo aumento do acesso à justiça, porque boa parte das novas demandas, aparentemente, é constituída de litígios precariamente configurados, que sequer deveriam ser objeto de processo judicial, podendo ser mais convenientemente resolvidos, do ponto de vista social, pelos meios extrajudiciais de solução de controvérsias.

4 - O individualismo, que tradicionalmente marcou o desenvolvimento dos institutos processuais, tem dificultado a consolidação da jurisdição coletiva. Os obstáculos inerentes a essa jurisdição provocam atrasos no desenvolvimento processual que induzem certa aversão ao processo coletivo por parte dos integrantes do Judiciário, assim como os advogados não se sentem atraídos pela ideia de molecularização de conflitos que pode reduzir o seu campo de atuação. A chamada Crise do Judiciário, no sentido do recrudescimento do problema do descompasso entre a demanda e a oferta de serviços judiciários à população, tem exigido a adoção de soluções discutíveis do ponto de vista da qualidade da prestação. Nesse contexto, a tutela coletiva, em especial dos interesses individuais homogêneos, surge como uma das soluções com maior potencial para, sem perda de qualidade, otimizar o trabalho jurisdicional no Brasil, um país que talvez não tenha recursos para montar uma estrutura judiciária cara como é a necessária para fazer frente à litigiosidade apenas por meio da jurisdição singular.

5 - A tutela de interesses individuais homogêneos na jurisdição coletiva caracteriza-se pela presença das condições da ação coletiva, em especial pela aferição da sua conveniência, decorrente da superioridade que possa apresentar em relação à jurisdição singular, em tese uma opção. A possibilidade dessa tutela decorre da existência dos elementos homogêneos que caracterizam tais interesses, devendo formar um núcleo, passível de definição na sentença do processo coletivo, composto pela existência da obrigação, a identidade do devedor e a natureza da prestação, no mínimo. A prevalência dos aspectos homogêneos não afeta a própria homogeneidade, que decorre exclusivamente da origem comum; afeta a utilidade da tutela coletiva desses interesses, que ficará comprometida se houver controvérsia sobre o próprio núcleo mínimo de homogeneidade, não resolvível de plano. 
Existe utilidade na tutela coletiva de interesses individuais homogêneos surgidos em decorrência de dano provocado pelo contato com substâncias cuja nocividade potencial careça de comprovação (fumo, asbesto etc.), porque é possível definir o núcleo mínimo de homogeneidade na sentença genérica sem precisar decidir controvérsias envolvendo questões de caráter individual, que podem e devem ser relegadas para a liquidação individual.

6 - A conveniência da tutela coletiva de interesses individuais homogêneos depende da relevância social por eles apresentada e da dificuldade da superação dos obstáculos ao acesso à justiça que a eles sejam apresentados. Alguns bens jurídicos têm a sua relevância indicada pelas garantias constitucionais que mereceram, outros pela nota da indisponibilidade agregada pelo legislador ordinário. Determinadas lesões também aumentam a importância da sua tutela em razão da ampla insatisfação social que geram, sejam elas causadas pela inação estatal ou pela ganância privada, cuja impunidade só serve para estimular a multiplicação e o agravamento das violações. Alguns dos principais obstáculos ao acesso à justiça dos titulares de interesses individuais homogêneos particularmente superáveis na tutela coletiva são a hipossuficiência (econômica, técnica ou cultural), a dispersão dos lesados e a insignificância dos prejuízos individuais. Está presente a conveniência da tutela coletiva de todos os interesses individuais homogêneos constitucionalmente garantidos, legalmente indisponíveis ou gravemente violados; as situações de dúvida sobre a conveniência devem ser resolvidas em favor da preferência pela tutela coletiva, diante das suas enormes vantagens.

7 - Os interesses individuais homogêneos podem ser tutelados na jurisdição singular não apenas em lides individuais, mas também em lides plurais, por meio de litisconsórcio, mas isso constitui uma solução limitada porque exige a definição completa das obrigações a serem impostas, não apenas do seu núcleo comum, o que inviabiliza uma demanda formada por um número muito grande de partes. Não há como estipular um número fixo a partir do qual a opção do litisconsórcio deixe de ser interessante e a tutela coletiva passe a ser conveniente, porque as dificuldades processuais que determinam essa escolha variam de caso a caso, mas isso ocorrerá toda vez que for necessário limitar o litisconsórcio e a tutela coletiva mostrar-se possível. Conforme a espécie de litisconsórcio do qual resultaria a tutela desses interesses na jurisdição singular, a homogeneidade poderá estar presente (litisconsórcio comum) ou necessariamente estará presente (litisconsórcio unitário), sendo 
a tutela coletiva, sempre que possível, a melhor alternativa, se facultativo, ou a única alternativa, se necessário e numeroso.

8 - A class action é a ação coletiva no Direito norte-americano, com fundas raízes no sistema da commom law. Não existe uma correspondência entre as espécies admitidas naquele ordenamento e no nosso, mas uma delas serviu de inspiração ao legislador brasileiro para a tutela de interesses individuais homogêneos, a "class action for damages", voltada a pretensões indenizatórias por danos individualmente sofridos com base na responsabilidade civil, exigindo-se a predominância de questões comuns sobre as individuais e a superioridade em relação aos diversos métodos alternativos à ação coletiva lá existentes, judiciais e extrajudiciais. O processamento de demanda na jurisdição coletiva do Direito norte-americano é autorizado mediante decisão interlocutória denominada certificação, de grande importância prática, porque aumenta muito o poder de negociação do grupo perante o réu. Para essa autorização exige-se, de forma cumulada, que o litisconsórcio seja impraticável, que existam questões comuns, que a pretensão do autor coletivo seja típica do grupo e que este seja um representante adequado. Este último é o mais importante requisito porque dele decorre o respeito à cláusula do devido processo legal, pois a decisão vinculará todos os membros do grupo, incluindo os ausentes; por esse motivo, pode ser objeto de controle judicial também no sistema brasileiro, embora aqui com muito menor amplitude.

9 - O marco da consagração da tutela coletiva no Brasil foi a Lei da Ação Civil Pública, de 1985, embora houvesse outras previsões anteriores, menos abrangentes. Porém, nela não havia a previsão da tutela de interesses individuais homogêneos, que foi introduzida pelo Código de Defesa do Consumidor, de 1990, que também definiu os demais interesses transindividuais e sistematizou melhor a tutela coletiva em geral. Ambos os diplomas são integrados, formando um sistema legal de tutela coletiva brasileiro, com o Código de Processo Civil funcionando como norma geral subsidiária. As ações em defesa de interesses individuais homogêneos de consumidores serão reguladas pelo Código de Defesa do Consumidor, aplicando-se a Lei da Ação Civil Pública subsidiariamente, naquilo que não contrariar aquele; para as ações de tutela de interesses individuais homogêneos não referidos às relações de consumo, a regulação será com base na Lei da Ação Civil Pública, aplicando-se o Código de Defesa do Consumidor apenas nas omissões. 10 - No sistema brasileiro, a legitimidade para a ação coletiva é relativamente presumida pela lei, em favor de entes contidos em previsão exaustiva, sendo do tipo concorrente e 
disjuntiva, isto é, cada legitimado pode atuar juntamente com os outros e também na falta dos outros. No regime do Código de Defesa do Consumidor, a sentença na ação para tutela de interesses individuais homogêneos faz coisa julgada erga omnes no plano coletivo, pro et contra; no plano individual a sentença coletiva não faz coisa julgada, se desfavorável, e pode ser transportada, se favorável. No regime da Lei da Ação Civil Pública, a coisa julgada é secundum eventum litis condicionada, ou seja, não faz coisa julgada a sentença de improcedência fundamentada em ausência de prova. Diversas leis têm sido aprovadas por iniciativa do Poder Executivo com o propósito de restringir a tutela coletiva. As muitas críticas da doutrina não têm servido para convencer os tribunais acerca da aptidão dessas normas para produzir efeitos, ainda que se possa entender serem contrárias ao interesse comum de desenvolvimento da tutela coletiva para propiciar mais acesso à justiça e maior racionalização do trabalho judiciário.

11 - É forte a convicção da comunidade jurídica sobre a necessidade de reforma completa do sistema legal da tutela coletiva no Brasil, com revogação da Lei da Ação Civil Pública e dos dispositivos processuais do Código de Defesa do Consumidor. Diversos projetos de lei nesse sentido têm sido apresentados e discutidos, como o Código Modelo de Processos Coletivos para Ibero-América, os anteprojetos de Código Brasileiro de Processos Coletivos da USP e o da UERJ/Unesa e, mais recentemente, o anteprojeto de nova Lei da Ação Civil Pública, denominado "Sistema Único Coletivo". A maioria apresenta avanços importantes, como a aferição expressa da representatividade adequada, a ampliação da legitimidade e a unificação das normas para boa parte das ações coletivas em sentido amplo. Alguns graves problemas verificados ultimamente, porém, não receberam encaminhamento de solução efetiva nessas propostas, como a proliferação de ações individuais e coletivas tratando de interesses individuais homogêneos, a possibilidade de ações assemelhadas às coletivas na jurisdição singular, com todos os inconvenientes daí decorrentes, e o acúmulo de ações versando matérias repetitivas nos juizados especiais, que não podem ser coletivizadas.

12 - A legitimação na tutela coletiva não pode ser classificada pelos critérios tradicionais porque não é definida de acordo com a titularidade do interesse, mas a partir da idoneidade social do portador. O Ministério Público será legitimado a propor ação em defesa de interesses individuais homogêneos sempre que a lei definir esses interesses como indisponível, como tutelável pelo parquet ou socialmente relevante, expressamente. Essa legitimidade, evidentemente, só prevalece enquanto tais interesses são tratados coletivamente e na perspectiva da relevância social que apresentam, de modo que não cabe 
ao Ministério Público promover a execução da sentença genérica em favor de particulares, ainda que na forma coletiva.

13 - Nada impede o controle de constitucionalidade em ações coletivas, não obstante eventual eficácia erga omnes da coisa julgada, desde que se trate de questão incidente (controle difuso), não fique afastado o acesso ao Supremo Tribunal Federal mediante recurso extraordinário e não se trate de ação objetiva dissimulada. A veiculação de matéria tributária em ação coletiva, embora constitui origem propícia para formação de interesses individuais homogêneos e o seu tratamento coletivo trouxesse todas as vantagens dessa espécie de tutela, está impedida por disposição legal válida. A exigência de que as associações comprovem autorização específica de seus membros para propor ação coletiva, porém, é inaplicável, porque contraria autorização constitucional expressa. A sentença genérica, seja considerada meramente declaratória ou condenatória, não constitui título executivo judicial, mesmo diante da norma do inciso I do art. 475-N do Código de Processo Civil, porque não define completamente a obrigação geral a que se refere, dependente de liquidação de que poderá resultar a inexistência da obrigação no caso específico. Se a liquidação for dispensável, porém, a sentença poderá ser executada diretamente sem qualquer outro provimento na fase de conhecimento. A restrição territorial da competência para as ações propostas por entidade associativa (art. $2^{\circ}$-A da Lei n. 9.494/97), ainda que se trate de retrocesso no desenvolvimento da jurisdição coletiva, não pode ser considerada inconstitucional.

14 - A limitação territorial da eficácia da coisa julgada, embora constitua outra restrição indesejável à consolidação da molecularização dos conflitos, não é inconstitucional, mas aplica-se apenas às ações coletivas propostas com base na Lei da Ação Civil Pública (cuja eficácia será também erga omnes e secundum eventum litis condicionada), não às propostas a partir das disposições do Código de Defesa do Consumidor (cuja eficácia será, no caso dos interesses individuais homogêneos, erga omnes). Não há litispendência entre ações individuais e coletivas versando interesses individuais homogêneos, o que existe é o direito de transporte para a ação individual da sentença coletiva, caso favorável, que poderá ser extinto se o autor da ação individual não suspendê-la após notícia, nos autos, do ajuizamento da ação coletiva. A litispendência entre ações coletivas deve ser verificada a partir da identidade da coletividade substituída, não do autor coletivo.

15 - A legitimação do Ministério Público para promover a execução da sentença genérica é extraordinária, mas a autorização legal restringe-se à execução coletiva e em favor do 
fundo de defesa dos direitos difusos. A competência para promover a liquidação é do juízo da fase de conhecimento, em virtude do veto ao dispositivo que autorizaria a liquidação também no foro do domicílio do liquidante. A liquidação será por artigos, como regra, podendo, excepcionalmente, ser também por cálculo aritmético (se não houver discussão sobre a qualidade do credor e a sentença trouxer fórmula matemática para apuração dos danos sofridos) ou por arbitramento (se necessário comprovar os danos mediante perícia). 


\section{BIBLIOGRAFIA ${ }^{399}$}

\section{A - LIVROS E PERIÓDICOS}

AGUIAR, Leandro Katscharowski. Tutela coletiva de direitos individuais e sua execução. São Paulo: Dialética, 2002.

ALMEIDA, Gregório Assagra de. Direito processual coletivo brasileiro. São Paulo: Saraiva, 2003.

ALMEIDA, João Batista de. Aspectos controvertidos da ação civil pública. São Paulo: Editora Revista dos Tribunais, 2001.

ALVES, Rogério Pacheco. As prerrogativas da administração pública nas ações coletivas. Dissertação de Mestrado em Sociologia e Direito da Universidade Federal Fluminense. Rio de Janeiro 2005. Disponível em <http://www.uff.br/ppgsd/Dissertacoes/rogerio2005.pdf>. Acesso em 19/05/2008.

ARAÚJO FILHO, Luis Paulo da Silva. Ações coletivas: a tutela jurisdicional dos direitos individuais homogêneos. Rio de Janeiro: Forense, 2000.

. Tutela jurisdicional dos direitos individuais homogêneos. In: Revista Forense, São Paulo, mar./abr. 2002, p. 363-368.

ARAÚJO, Rodrigo Souza Mendes de. A ação para a tutela dos interesses individuais homogêneos: a class action for damages brasileira? In: MAZZEI, Rodrigo; NOLASCO, Rita (org.). Processo civil coletivo. São Paulo: Quartier Latin, 2005.

ARRUDA ALVIM, José Manoel et al. Código do consumidor comentado. $2^{\mathrm{a}}$ ed. São Paulo: Editora Revista dos Tribunais, 1995.

BARBOSA MOREIRA, José Carlos. A ação popular do Direito brasileiro como instrumento de tutela coletiva dos chamados "interesses difusos". In: Revista de Processo n. 28, São Paulo, Editora Revista dos Tribunais, out./dez. 1982, p. 7-19. . Ações coletivas na constituição federal de 1988. In: Revista de Processo n. 61, São Paulo, Editora Revista dos Tribunais, jan./mar. 1991, p. 188.

\footnotetext{
${ }^{399}$ De acordo com: Associação Brasileira de Normas Técnicas. NBR 6023: informação e documentação: referências: elaboração. Rio de Janeiro, 2002.
} 
BARROSO, Luis Roberto. A proteção coletiva dos direitos no Brasil e alguns aspectos da class action norte-americana. In: Revista de Processo n. 130, São Paulo, Editora Revista dos Tribunais, dez. 2005, p. 131-153.

BEDAQUE, José Roberto dos Santos. Direito e processo: influência do direito material sobre o processo. $4^{\mathrm{a}}$ ed. rev. amp. São Paulo: Malheiros, 2006.

BENJAMIN, Antonio Herman de Vasconcellos. A Insurreição da Aldeia Global contra o Processo Civil Clássico: apontamentos sobre a opressão e a libertação judiciais do meio ambiente e do consumidor. Biblioteca Digital do Superior Tribunal de Justiça, disponível em <http://bdjur.stj.gov.br/dspace/handle/2011/8688>.Acesso em $30 / 10 / 2008$.

BOBBIO, Norberto. A era dos direitos. Tradução de Carlos Nelson Coutinho. Rio de Janeiro: Campus, 1992.

BRANCO, Letícia Rezende Castelo. Legitimidade ativa do Ministério Público nas ações coletivas para a defesa dos interesses individuais homogêneos. In: Repertório de Jurisprudência IOB, vol. III, n. 10, São Paulo, 2a quinzena de maio de 2007, p. 296290.

BUENO, Cássio Scarpinella. As class actions norte-americanas e as ações coletivas brasileiras: pontos para um reflexão conjunta. In: Revista de Processo n. 82, São Paulo, Editora Revista dos Tribunais, abr./jun. 1996, p. 92-151.

BULOS, Uadi Lammêgo. Constituição federal anotada. $7^{a}$ ed. rev. atual. São Paulo: Saraiva, 2007.

BURNS, Edward MacNall. História da civilização ocidental. $3^{\mathrm{a}}$ ed. Porto Alegre: Globo, 1975.

CALDAS AULETE. Dicionário contemporâneo da língua portuguesa. $3^{\mathrm{a}}$ ed. Rio de Janeiro: Delta, 1980.

CAPPELLETTI, Mauro. Formações sociais e interesses coletivos diante da justiça civil. In: Revista de Processo n. 05, São Paulo, Editora Revista dos Tribunais, jan./mar. 1977, p. 128-159.

CAPPELLETTI, Mauro; GARTH, Bryant. Acesso à justiça. Porto Alegre: Sergio Antonio Fabris Editor, 1988. 
CARNEIRO, Athos Gusmão. O mandado de segurança coletivo como garantia dos cidadãos. In: TEIXEIRA, Sálvio de Figueiredo (org.). As garantias do cidadão na justiça. São Paulo: Saraiva, 1993.

CASTILHO, Ricardo. Acesso à justiça. São Paulo: Atlas, 2006.

COSTA MACHADO, Antonio Cláudio. A intervenção do Ministério Público no processo civil brasileiro. $2^{\mathrm{a}}$ ed. rev. atual. São Paulo: Saraiva, 1998.

CRUZ E TUCCI, José Rogério. “Class action” e mandado de segurança coletivo. São Paulo: Saraiva, 1990.

. Limites subjetivos da eficácia da sentença e da coisa julgada nas ações coletivas. In: Revista do Advogado da AASP, n. 89, dez. 2006, p. 67-84.

DAVID, René. Os grandes sistemas do Direito contemporâneo. São Paulo: Martins Fontes, 2002.

DI LORENZO, Thomas. Cato Handbook for Congress - 105th Congress. Disponível em <www.cato.org/pubs/handbook/hb105-39.html>. Acesso em 18/09/2008.

DINAMARCO, Cândido Rangel. Instituições de Direito processual civil - vol I. $4^{\mathrm{a}}$ ed. rev. atual. São Paulo: Malheiros, 2004.

. Instituições de Direito Processual Civil - vol II. $4^{\mathrm{a}}$ ed. rev. atual. São Paulo: Malheiros, 2004.

. Instituições de Direito Processual Civil - vol III. $4^{\mathrm{a}}$ ed. rev. atual. São Paulo: Malheiros, 2004.

. Instrumentalidade do processo. $13^{\mathrm{a}}$ ed. rev. atual. São Paulo: Malheiros, 2008.

. Litisconsórcio. $7^{\mathrm{a}}$ ed. rev. atual. amp. São Paulo: Malheiros, 2002.

DINAMARCO, Pedro da Silva. Ação civil pública. São Paulo: Saraiva, 2001.

Competência, conexão e prevenção nas ações coletivas. In: MILARÉ, Édis (coord.). A ação civil pública - Após 20 anos: efetividade e desafios. São Paulo: Editora Revista dos Tribunais, 2005.

ECO, Humberto. Como se faz uma tese. 18 a ed. São Paulo: Perspectiva, 2003.

FAUSTO, Boris. História do Brasil. $2^{a}$ ed. São Paulo: EDUSP, 1995. 
FREIRE JÚNIOR, Américo Bedê. Os poderes do juiz nas ações coletivas e breves sugestões de lege ferenda ao aprimoramento do processo coletivo. In: Revista de Processo n. 117, São Paulo, Editora Revista dos Tribunais, set./out. 2004, p. 129134.

FREITAS, Vladimir Passos de. A perícia como requisito da administração da justiça ambiental. Disponível em $<$ http://www.abdir.com.br/doutrina/ver.asp?art_id=\&categoria=Tutela Processual ambiental>. Acesso em 10/12/2008.

GAJARDONI, Fernando da Fonseca. Técnicas de aceleração do processo. São Paulo: Lemos \& Cruz, 2003.

GIDI, Antonio. A class action como instrumento de tutela coletiva dos direitos. São Paulo: Editora Revista dos Tribunais, 2007.

. Código de processo civil coletivo - um modelo para países de direito escrito. In: MAZZEI, Rodrigo; NOLASCO, Rita (coord.). Processo civil coletivo. São Paulo: Quartier Latin, 2005.

. Coisa julgada e litispendência em ações coletivas. São Paulo: Saraiva, 1995.

GRECO FILHO, Vicente. Direito processual civil brasileiro - $1^{\mathrm{o}}$ vol. $9^{\mathrm{a}}$ ed. São Paulo: Saraiva, 1994.

GRINOVER, Ada Pellegrini. A tutela jurisdicional dos interesses difusos. In: Revista Brasileira de Direito Processual n. 16, Rio de Janeiro, Forense, 1978, p. 13-42. - Ações coletivas ibero-americanas: novas questões sobre a legitimidade e a coisa julgada. In: Revista Forense vol. 361, São Paulo, maio/jun. 2002, p. 3-12.

- Da class action for damages à ação de classe brasileira: os requisitos de admissibilidade. In: Revista Forense n. 352, Rio de Janeiro, out./nov./dez. 2000, p. $03 / 14$.

GRINOVER, Ada Pellegrini et al. Código brasileiro de defesa do consumidor comentado pelos autores do anteprojeto. $5^{\mathrm{a}}$ ed. rev. atual. amp. Rio de Janeiro: Forense Universitária, 1998. 
GRINOVER, Ada Pellegrini; MENDES, Aloísio Gonçalves de Castro; WATANABE, Kazuo. Direito processual coletivo e o anteprojeto de código brasileiro de processos coletivos. São Paulo: Editora Revista dos Tribunais, 2007.

KLONNOFF, Robert H. Class actions and other multi-party litigation. St. Paul: West Group, 1999.

KOMATSU, Roque. A tentativa de conciliação no processo civil. Dissertação de Mestrado em Direito da Universidade de São Paulo. São Paulo, 1978.

LAZZARINI, Marilena. As investidas contra as ações civis públicas. In: LUCON, Paulo Henrique dos Santos (org.). Tutela coletiva. São Paulo: Atlas, 2006.

LEAL, Márcio Flávio Mafra. Ações Coletivas: história, teoria e prática. Porto Alegre: Sergio Antonio Fabris Editor, 1998.

LENZA, Pedro. Teoria geral da ação civil pública. São Paulo: Editora Revista dos Tribunais, 2003.

LEONEL, Ricardo de Barros. Manual do processo coletivo. São Paulo: Editora Revista dos Tribunais, 2002.

MACHADO, Hugo de Brito. O Ministério Público e os direitos individuais homogêneos. In: Repertório IOB de Jurisprudência, vol. III, n. 18, São Paulo, 2a quinzena de set. 1996, p. 324-323.

MANCUSO, Rodolfo de Camargo. Ação civil pública para tutela dos interesses dos titulares de valores mobiliários e investidores do mercado. In: Revista dos Tribunais, vol. 650, São Paulo, Editora Revista dos Tribunais, dez. 1989, p. 31-39. . Ação civil pública trabalhista: análise de alguns pontos controvertidos. In: Revista dos Tribunais n. 732, São Paulo, Editora Revista dos Tribunais, out. 1996, p. 11-37. - Ação civil pública. $5^{\mathrm{a}}$ ed. rev. atual. amp. São Paulo: Editora Revista dos Tribunais, 1997.

. Ação popular. $5^{\mathrm{a}}$ ed. rev. atual. amp. São Paulo: Editora Revista dos Tribunais, 2003.

. Defesa do Consumidor. Reflexões acerca da eventual concomitância de ações coletivas e individuais. In: Revista dos Tribunais, vol. 676, São Paulo, Editora Revista dos Tribunais, fev. 1992, p. 34-38. 
MANCUSO, Rodolfo de Camargo. Interesses difusos. $6^{\text {a }}$ ed. rev. atual. amp. São Paulo: Editora Revista dos Tribunais, 2004.

. Jurisdição coletiva e coisa julgada. São Paulo: Editora Revista dos Tribunais, 2007.

. Manual do consumidor em juízo. $3^{\mathrm{a}}$ ed. rev. atual. amp. São Paulo: Saraiva, 2001.

Sobre a legitimação do Ministério Público em matéria de interesses individuais homogêneos. In: MILARÉ, Edis. Ação civil pública (Lei 7.347/85 - Reminiscências e reflexões após dez anos de aplicação). São Paulo: Editora Revista dos Tribunais, 1995.

MARCATO, Antonio Carlos (coord.). Código de processo civil interpretado. $2^{\mathrm{a}}$ ed. São Paulo: Atlas, 2005.

MARINS, James. Ações coletivas em matéria tributária. In: Revista de Processo n. 76, São Paulo, Editora Revista dos Tribunais, out./dez. 1994, p. 97-103.

MARTINS, Ives Gandra da Silva. Ação civil pública para defesa de direitos individuais. In: WALD, Arnoldo. Aspectos polêmicos da ação civil pública. São Paulo: Saraiva, 2003.

. Ministério Público - direitos individuais disponíveis e ação civil pública. In: Revista Forense, vol. 330, Rio de Janeiro, abr./maio/jun. 1995, p. 251-260.

MAXIMILIANO, Carlos. Hermenêutica e aplicação do Direito. Rio de Janeiro: Forense, 1998.

MAZZILLI, Hugo Nigro. A defesa dos interesses difusos em juízo. $15^{\mathrm{a}}$ ed. rev. amp. atual. São Paulo: Saraiva, 2002.

MENDES, Aloísio Gonçalves de Castro. Ações coletivas: no Direito comparado e nacional. São Paulo: Editora Revista dos Tribunais, 2002.

. Sentença, Liquidação e Execução nos Processos Coletivos para a tutela dos direitos individuais homogêneos. In: SANTOS, Ernane Fidélis dos; WAMBIER, Luiz Rodrigues; NERY JÚNIOR, Nelson; WAMBIER, Teresa Arruda Alvim (coord.). Execução Civil - Estudos em homenagem ao professor Humberto Theodoro Júnior. São Paulo: Editora Revista dos Tribunais, 2007.

MESQUITA, José Inácio Botelho de. A coisa julgada. Rio de Janeiro: Forense, 2006. 
MIRRA, Álvaro Luiz Valery. Ação civil pública e a reparação do dano ao meio ambiente. São Paulo: Juarez de Oliveira, 2002.

MONTENEGRO FILHO, Misael. Importância da ação civil pública no panorama da abarrotada justiça brasileira: vicissitudes e perigos da ação em estudo. In: MAZZEI, Rodrigo; NOLASCO, Rita (coord.). Processo civil coletivo. São Paulo: Quartier Latin, 2005.

NERY JÚNIOR, Nelson. A ação civil pública no processo do trabalho. In: MILARÉ, Edis (coord.). Ação civil pública, lei 7.347/1985 - 15 anos. 2a ed. São Paulo: Editora Revista dos Tribunais, 2002.

. Ação civil pública trabalhista e os direitos individuais homogêneos. In: DIDIER JÚNIOR, Fredie. Execução Civil - Estudos em homenagem ao professor Paulo Furtado. Rio de Janeiro: Lúmen Júris, 2006.

. Princípios do processo civil na constituição federal. $8^{\mathrm{a}}$ ed. São Paulo: Editora Revista dos Tribunais, 2004.

NERY JÚNIOR, Nelson; NERY, Rosa Maria de Andrade. Código de processo civil comentado e legislação extravagante. $7^{\mathrm{a}}$ ed. rev. amp. São Paulo: Editora Revista dos Tribunais, 2003.

. Código de processo civil comentado e legislação extravagante. $4^{\mathrm{a}}$ ed. rev. amp. São Paulo: Editora Revista dos Tribunais, 1999.

NUNES, Rizzato. As ações coletivas e as definições de direito difuso, coletivo e individual homogêneo. In: MAZZEI, Rodrigo; NOLASCO, Rita (coord.). Processo civil coletivo. São Paulo: Quartier Latin, 2005.

. Manual da monografia jurídica. $4^{\mathrm{a}}$ ed. São Paulo: Saraiva, 2002.

OLIVEIRA, Juarez de (coord.). Comentários ao Código de Proteção ao Consumidor. São Paulo: Saraiva, 1991.

PRUDENTE, Antonio de Souza. A tutela coletiva e de evidência no Juizado Especial Federal Cível e o acesso pleno à justiça. In: Revista da Escola de Magistratura Federal da $5^{\text {a }}$ Região, n. 15, Recife, 2007, p. 47-56.

RAO, Vicente. O Direito e a vida dos direitos - vol. 1, tomo I. $2^{\mathrm{a}}$ ed. São Paulo: Editora Resenha Universitária, 1976. 
ROCHA, Ibraim. Litisconsórcio, efeitos da sentença e coisa julgada na tutela coletiva. Rio de Janeiro: Forense, 2002.

RODRIGUES, Francisco Cesar Pinheiro. Progressos profissionais que se voltam contra os profissionais. Disponível em $<$ http://www.amb.com.br/?secao=artigo_detalhe\&art_id=660\&>. Acesso em $12 / 08 / 2008$.

SÁ, José Adonis Callou de Araújo. Ação civil pública e controle de constitucionalidade. Belo Horizonte: Del Rey, 2002.

SADEK, Maria Teresa. Poder Judiciário: Perspectivas de Reforma. Opinião Pública, Campinas, vol. X, n. 1, maio de 2004, p. 12. Disponível em <http://www.scielo.br/pdf/op/v10n1/20314.pdf>. Acesso em 25/05/2008.

SALLES, Carlos Alberto. Execução judicial em matéria ambiental. São Paulo: Editora Revista dos Tribunais, 1999.

. O Direito do Consumidor e suas influências sobre os mecanismos de regulação do mercado. In: Revista de Direito do Consumidor, n. 17, jan./mar. 1999, p. 85-96.

SARAIVA, José Hermano. História concisa de Portugal. $18^{\mathrm{a}}$ ed. Mem Martins Codex: Europa-América, 1996.

SHIMURA, Sergio Seiji. Tutela coletiva e sua efetividade. São Paulo: Método, 2006.

SILVA, José Afonso da. Curso de Direito Constitucional positivo. $19^{\mathrm{a}}$ ed. rev. atual. São Paulo: Malheiros, 2001.

SOARES, Guido Fernando da Silva. Common Law - Introdução ao Direito dos EUA. $2^{\text {a }}$ ed. São Paulo: Editora Revista dos Tribunais, 2000.

TAVARES, André Ramos. Apontamentos acerca do princípio constitucional do acesso à justiça. In: Boletim Científico da Escola Superior do Ministério Público da União, ESMPU, Ano II, n. 6, Brasília, jan./mar. 2003, p. 9-36.

THEODORO JÚNIOR, Humberto. Algumas observações sobre a ação civil pública e outras ações coletivas. In: Revista Síntese de Direito Civil e Processual Civil n. 9, Porto Alegre, jan./fev. 2001, p. 139-161.

VELOSO, Carlos Mário da Silva. Processo judicial tributário: medidas judiciais que o integram e a legitimidade do Ministério Público para a ação civil pública que tem 
por objeto o não pagamento de um tributo. In: Revista de Direito Bancário e do Mercado de Capitais n. 6, São Paulo, Editora Revista dos Tribunais, set./dez. 1999, p. 13-20.

VENTURI, Elton. Execução da tutela coletiva. São Paulo: Malheiros, 2000.

VIGLIAR, José Marcelo Menezes. Ação civil pública ou ação coletiva? In: MILARÉ, Edis (coord.). Ação civil pública, lei 7.347/1985 - 15 anos. 2a ed. São Paulo: Editora Revista dos Tribunais, 2002. . Ação civil pública. $5^{\mathrm{a}}$ ed. rev. amp. São Paulo: Atlas, 2001.

Alguns aspectos sobre a ineficácia do procedimento especial destinado aos interesses individuais homogêneos. In: MILARÉ, Édis. A ação civil pública após 20 anos: efetividade e desafios. São Paulo: Editora Revista dos Tribunais, 2005.

. Interesses individuais homogêneos e seus aspectos polêmicos. São Paulo: Saraiva, 2003.

Tutela jurisdicional coletiva. $3^{\mathrm{a}}$ ed. São Paulo: Atlas, 2001.

VIGORITI, Vincenzo. Interessi collettivi e proceso. La legittimazaione ad agire. Milano: Dott A. Giuffré Editore, 1979.

WALD, Arnoldo. Contratos bancários de depósito em caderneta de poupança. Descabimento de ação civil pública e irretroatividade da lei. In: WALD, Arnoldo. Aspectos polêmicos da ação civil pública. São Paulo: Saraiva, 2003.

WATANABE, Kazuo. Acesso à justiça e sociedade moderna. In: GRINOVER, Ada Pellegrini; DINAMARCO, Cândido Rangel; WATANABE, Kazuo. Participação e processo. São Paulo: Editora Revista dos Tribunais, 1988.

. Cultura da sentença e cultura da pacificação. In: YARSHELL, Flavio Luiz; MORAES, Maurício Zanoide. Estudos em homenagem à professora Ada Pellegrini Grinover. São Paulo: DPJ Editora, 2005.

. Demandas coletivas e os problemas emergentes da práxis forense. In: Revista de Processo n. 67, São Paulo, Editora Revista dos Tribunais, jul./set. 1992, p. 15-25. . Finalidade maior dos juizados especiais cíveis. In: Cidadania e Justiça, ano 3, n. 7 , Rio de Janeiro, $2^{\circ}$ semestre de 1999, p. 32-37. 
WATANABE, Kazuo. Relação entre demanda coletiva e demandas individuais. In: Revista de Processo n. 139, São Paulo, Editora Revista dos Tribunais, set. 2006, p. 28-35.

YARSHELL, Flavio Luiz. Brevíssimas reflexões a propósito da legitimidade passiva nas ações civis públicas envolvendo atividades sujeitas a regulação. In: LUCON, Paulo Henrique dos Santos (org.). Tutela coletiva. São Paulo: Atlas, 2006.

- Observações a propósito da liquidação na tutela de direitos individuais homogêneos. In: WAMBIER, Teresa Arruda Alvim (coord.). Repertório de Jurisprudência e Doutrina - Atualidades sobre liquidação de sentença. São Paulo: Editora Revista dos Tribunais, 1997.

ZANELLATO, Marco Antonio. A defesa dos interesses individuais homogêneos dos consumidores pelo Ministério Público. In: Revista do Advogado n. 89, São Paulo, dez. 2006, p. 96-106.

ZAVASCKI, Teori Albino. Ministério Público, ação civil pública e defesa de direitos individuais homogêneos. In: Revista Forense, vol. 92, n. 333, Rio de Janeiro, jan./fev./mar. 1996, p. 123/137.

. Processo Coletivo - Tutela de direitos coletivos e tutela coletiva de direitos. $2^{\mathrm{a}}$ ed. rev. atual. São Paulo: Editora Revista dos Tribunais, 2007. 


\section{B - DOCUMENTOS}

Acesso à Justiça por Sistemas Alternativos de Administração de Conflitos - Mapeamento nacional de programas públicos e não governamentais. Brasília: Secretaria Especial de $\begin{array}{lllll}\text { Reforma do } & \text { Judiciário, } & \text { Disponível }\end{array}$ $<$ http://www.direitos.org.br/index.php?option=com_remository\&Itemid=99\&func=fileinfo \&id=259> . Acesso em 18/11/2008.

Boletim de Notícias da página do Instituto de Mediação e Arbitragem do Estado de São Paulo. Disponível em <http://www.imaesp.com.br>. Acesso em 21/05/2008.

Desabamento do Palace II completa dez anos; vítimas buscam indenização. Folha Online. Disponível em <www1.folha.uol.com.br/folha/cotidiano/ult95u374662.shtml>. Acesso em $31 / 07 / 2008$.

Diagnóstico do Poder Judiciário. Brasília: Secretaria Especial de Reforma do Judiciário, $\begin{array}{llllll}\text { agosto de } & \text { 2004, } & \text { p. } & \text { Disponível em }\end{array}$ $<$ http://www.direitos.org.br/index.php?option=com_remository\&Itemid=99\&func=fileinfo \&id=156> . Acesso em 10/10/2008.

Memória: 55 pessoas morreram no Bateau Mouche.Globo Online. Disponível em <www.oglobo.globo.com/rio/mat/2006/10/16/286116874.asp>. Acesso em 31/07/2008.

Prazo para revisão da caderneta de poupança está no fim. Disponível em <http://www1.folha.uol.com.br/folha/dinheiro/ult91u480413.shtml>. Acesso em 20/12/2008.

Mensagem n. 664, de 11/09/90, da Subchefia para Assuntos Jurídicos da Casa Civil da Presidência da República. Disponível em<www.planalto.gov.br/ccivil_03/Leis/Mensagem_Veto/anterior_98/vep664-L807890.htm>. Acesso em 14/10/2008.

Queda do avião da TAM deixou 99 mortos há dez anos. Folha Online. Disponível em <www1.folha.uol.com.br/folha/cotidiano/ult95u126501.shtml>. Acesso em 31/07/2008.

Relatório Final do Projeto de Pesquisa Tutela Judicial dos Interesses Metaindividuais Ações Coletivas, Coordenação Executiva de Leslie Shérida Ferraz, Pesquisador Responsável Marcos Paulo Veríssimo. Brasília: Ideal Gráfica e Editora, 2007. Disponível em <http://www.mp.pr.gov.br/gabinete/pesqaccol.pdf>. Acesso em 29/11/2008. 


\title{
ANEXOS
}

\author{
A - Código modelo de processos coletivos para Ibero-América \\ B - Anteprojeto de Código Brasileiro de Processos Coletivos (UERJ/Unesa) \\ C - Anteprojeto de Código Brasileiro de Processos Coletivos (USP) \\ D - Anteprojeto de Lei da Ação Civil Pública (Sistema Único Coletivo) \\ E - Acórdão do Supremo Tribunal Federal: ED no AgR no RE 470.135-9/MT, de 22/05/07 \\ F - Acórdão do Supremo Tribunal Federal: Reclamação 600-0/190/SP, de 03/09/97 \\ G - Acórdão do Superior Tribunal de Justiça: Recurso Especial 411.529/SP, de 24/06/08 \\ H - Acórdão do Superior Tribunal de Justiça: Recurso Especial 880.385/SP, de 02/09/08
}




\section{ANEXO A \\ CÓDIGO MODELO DE PROCESSOS COLETIVOS PARA IBERO-AMÉRICA}

\section{Capítulo I - Disposições gerais}

Art $1^{0}$. Cabimento da aç̃o coletiva - A ação coletiva será exercida para a tutela de:

I - interesses ou direitos difusos, assim entendidos os transindividuais, de natureza indivisível, de que seja titular um grupo, categoria ou classe de pessoas ligadas por circunstâncias de fato ou vinculadas, entre si ou com a parte contrária, por uma relação jurídica base;

II - interesses ou direitos individuais homogêneos, assim entendido o conjunto de direitos subjetivos individuais, decorrentes de origem comum, de que sejam titulares os membros de um grupo, categoria ou classe.

Art $2^{\circ}$. Requisitos da acão coletiva - São requisitos da demanda coletiva:

I - a adequada representatividade do legitimado;

II - a relevância social da tutela coletiva, caracterizada pela natureza do bem jurídico, pelas características da lesão ou pelo elevado número de pessoas atingidas.

Par. $1^{\circ}$. Para a tutela dos interesses ou direitos individuais homogêneos, além dos requisitos indicados nos n. I e II deste artigo, é também necessária a aferição da predominância das questões comuns sobre as individuais e da utilidade da tutela coletiva no caso concreto.

Par. $2^{\circ}$. Na análise da representatividade adequada o juiz deverá analisar dados como:

a - a credibilidade, capacidade, prestígio e experiência do legitimado;

b - seu histórico na proteção judicial e extrajudicial dos interesses ou direitos dos membros do grupo, categoria ou classe;

c - sua conduta em outros processos coletivos;

(suprimir: d - sua capacidade financeira para a condução do processo coletivo;)

$\mathrm{d}$ - a coincidência entre os interesses dos membros do grupo, categoria ou classe e o objeto da demanda;

e - o tempo de instituição da associação e a representatividade desta ou da pessoa física perante o grupo, categoria ou classe.

Par. $3^{0}$ - $O$ juiz analisará a existência do requisito da representatividade adequada a qualquer tempo e em qualquer grau do procedimento, aplicando, se for o caso, o disposto no parágrafo $4^{\circ}$ do artigo $3^{\circ}$.

Art. $3^{\circ}$. Legitimação ativa. São legitimados concorrentemente à ação coletiva:

I - qualquer pessoa física, para a defesa dos interesses ou direitos difusos de que seja titular um grupo, categoria ou classe de pessoas ligadas por circunstâncias de fato;

II - o membro do grupo, categoria ou classe, para a defesa dos interesses ou direitos difusos de que seja titular grupo, categoria ou classe de pessoas ligadas entre si ou com a parte contrária por uma relação jurídica base e para a defesa de interesses ou direitos individuais homogêneos;

III - o Ministério Público, o Defensor do Povo e a Defensoria Pública;

IV - as pessoas jurídicas de direito público interno;

V - as entidades e órgãos da Administração Pública, direta ou indireta, ainda

que sem personalidade jurídica, especificamente destinados à defesa dos

interesses e direitos protegidos por este código;

VI - as entidades sindicais, para a defesa dos interesses e direitos da categoria; 
VII - as associações legalmente constituídas há pelo menos um ano e que incluam entre seus fins institucionais a defesa dos interesses e direitos protegidos neste código, dispensada a autorização assemblear.

VIII - os partidos políticos, para a defesa de direitos e interesses ligados a seus fins institucionais.

Par. $1^{\circ}$. O requisito da pré-constituição pode ser dispensado pelo juiz, quando haja manifesto interesse social evidenciado pela dimensão ou característica do dano, ou pela relevância do bem jurídico a ser protegido.

Par. $2^{\circ}$. Será admitido o litisconsórcio facultativo entre os legitimados.

Par. $3^{\circ}$. Em caso de relevante interesse social, o Ministério Público, se não ajuizar a ação ou não intervier no processo como parte, atuará obrigatoriamente como fiscal da lei.

Par. $4^{\circ}$. Em caso de inexistência do requisito da representatividade adequada, de desistência infundada ou abandono da ação por pessoa física, entidade sindical ou associação legitimada, o juiz notificará o Ministério Público e, na medida do possível, outros legitimados adequados para o caso a fim de que assumam, querendo, a titularidade da ação.

Par. $5^{\circ}$. O Ministério Público e os órgãos públicos legitimados poderão tomar dos interessados compromisso administrativo de ajustamento de sua conduta às exigências legais, mediante cominações, que terá eficácia de título executivo extrajudicial.

\section{Capítulo II - Dos provimentos jurisdicionais}

Art. $4^{\mathbf{0}}$. Efetividade da tutela jurisdicional - Para a defesa dos direitos e interesses protegidos por este código são admissíveis todas as espécies de ações capazes de propiciar sua adequada e efetiva tutela.

Art. 5 . Tutela jurisdicional antecipada - O juiz poderá, a requerimento da parte, antecipar, total ou parcialmente, os efeitos da tutela pretendida no pedido inicial, desde que, com base em prova consistente, se convença da verossimilhança da alegação e

I - haja fundado receio de ineficácia do provimento final ou

II - fique caracterizado o abuso de direito de defesa ou manifesto propósito protelatório do demandado.

Par. $1^{\circ}$. Não se concederá a antecipação da tutela se houver perigo de irreversibilidade do provimento antecipado, a menos que, num juízo de ponderação dos valores em jogo, a denegação da medida signifique sacrifício irrazoável de bem jurídico relevante.

Par. $2^{\circ}$. Na decisão que antecipar a tutela, o juiz indicará, de modo claro e preciso, as razões de seu convencimento.

Par. $3^{\circ}$. A tutela antecipada poderá ser revogada ou modificada a qualquer tempo, em decisão fundamentada.

Par. $4^{\circ}$. Se não houver controvérsia quanto à parte antecipada na decisão liminar, após a oportunidade de contraditório esta se tornará definitiva e fará coisa julgada, prosseguindo o processo, se for o caso, para julgamento dos demais pontos ou questões postos na demanda.

Art. $6^{0}$. Obrigaç̃es de fazer e não fazer - Na ação que tenha por objeto o cumprimento da obrigação de fazer ou não fazer, o juiz concederá a tutela específica da obrigação ou determinará providências que assegurem o resultado prático equivalente ao do adimplemento.

Par. $1^{\circ}$. O juiz poderá, na hipótese de antecipação de tutela ou na sentença, impor multa diária ao demandado, independentemente de pedido do autor, se for suficiente ou compatível com a obrigação, fixando prazo razoável para o cumprimento do preceito.

Par. $2^{\circ}$. O juiz poderá, de ofício, modificar o valor ou a periodicidade da multa, caso verifique que se tornou insuficiente ou excessiva.

Par. $3^{\circ}$. Para a tutela específica ou para a obtenção do resultado prático equivalente, poderá o juiz determinar as medidas necessárias, tais como busca e apreensão, remoção de coisas e pessoas, desfazimento de obra, impedimento de atividade nociva, além de requisição de força policial.

Par. $4^{\circ}$. A conversão da obrigação em perdas e danos somente será admissível se por elas optar o autor ou se impossível a tutela específica ou a obtenção do resultado prático correspondente.

Par. $5^{\circ}$. A indenização por perdas e danos se fará sem prejuízo da multa. 
Art. $7^{0}$. Obrigacões de dar - $\mathrm{Na}$ ação que tenha por objeto a obrigação de entregar coisa, determinada ou indeterminada, aplicam-se, no que couber, as disposições do artigo anterior.

Art. $\mathbf{8}^{\mathbf{0}}$. Ação indenizatória - Na ação condenatória à reparação dos danos provocados ao bem indivisivelmente considerado, a indenização reverterá ao Fundo dos Direitos Difusos e Individuais Homogêneos, administrado por um Conselho Gestor governamental, de que participarão necessariamente membros do Ministério Público, juízes e representantes da comunidade, sendo seus recursos destinados à reconstituição dos bens lesados ou, não sendo possível, à realização de atividades tendentes a minimizar a lesão ou a evitar que se repita, dentre outras que beneficiem o bem jurídico prejudicado.

Par. $1^{\circ}$. O Fundo será notificado da propositura de toda ação coletiva e sobre as decisões mais importantes do processo e poderá intervir nos processos coletivos em qualquer tempo e grau de jurisdição para demonstrar a inadequação do representante ou auxiliá-lo na tutela dos interesses ou direitos do grupo, categoria ou classe;

Par. $2^{\circ}$. O Fundo manterá registros que especifiquem a origem e a destinação dos recursos e indicará a variedade dos bens jurídicos a serem tutelados e seu âmbito regional;

Par. $3^{0}$. Dependendo da especificidade do bem jurídico afetado, da extensão territorial abrangida e de outras circunstâncias consideradas relevantes, o juiz poderá especificar, em decisão fundamentada, a destinação da indenização e as providências a serem tomadas para a reconstituição dos bens lesados, podendo indicar a realização de atividades tendentes a minimizar a lesão ou a evitar que se repita, dentre outras que beneficiem o bem jurídico prejudicado;

Par. $4^{\circ}$. A decisão que especificar a destinação da indenização indicará, de modo claro e preciso, as medidas a serem tomadas pelo Conselho Gestor do Fundo, bem como um prazo razoável para que tais medidas sejam concretizadas;

Par. $5^{\circ}$. Vencido o prazo fixado pelo juiz, o Conselho Gestor do Fundo apresentará relatório das atividades realizadas, facultada, conforme o caso, a solicitação de sua prorrogação, para complementar as medidas determinadas na decisão judicial.

\section{Capítulo III - Dos processos coletivos em geral}

Art. $9^{\circ}$. Competência territorial - É competente para a causa o foro:

I - do lugar onde ocorreu ou deva ocorrer o dano, quando de âmbito local;

II - da Capital, para os danos de âmbito regional ou nacional, aplicando-se as regras pertinentes de organização judiciária.

Art. 10. Pedido e causa de pedir - Nas ações coletivas, o pedido e a causa de pedir serão interpretados extensivamente.

Par. $1^{\circ}$. Ouvidas as partes, o juiz permitirá a emenda da inicial para alterar ou ampliar o objeto da demanda ou a causa de pedir.

Par. $2^{\circ}$. O juiz permitirá a alteração do objeto do processo a qualquer tempo e em qualquer grau de jurisdição, desde que seja realizada de boa-fé, não represente prejuízo injustificado para a parte contrária e o contraditório seja preservado.

Art. 11. Audiência preliminar - Encerrada a fase postulatória, o juiz designará audiência preliminar, à qual comparecerão as partes ou seus procuradores, habilitados a transigir.

Par. $1^{\circ}$. O juiz ouvirá as partes sobre os motivos e fundamentos da demanda e tentará a conciliação, sem prejuízo de sugerir outras formas adequadas de solução do conflito, como a mediação, a arbitragem e a avaliação neutra de terceiro.

Par. $\mathbf{2}^{\mathbf{0}}$ - A avaliação neutra de terceiro, obtida no prazo fixado pelo juiz, é sigilosa, inclusive para este, e não vinculante para as partes, sendo sua finalidade exclusiva a de orientá-las na tentativa de composição amigável do conflito.

Par. $3^{\circ}$. Preservada a indisponibilidade do bem jurídico coletivo, as partes poderão transigir sobre o modo de cumprimento da obrigação. 
Par. $4^{\circ}$. Obtida a transação, será homologada por sentença, que constituirá título executivo judicial.

Par. $5^{\circ}$. Não obtida a conciliação, sendo ela parcial, ou quando, por qualquer motivo, não for adotado outro meio de solução do conflito, o juiz, fundamentadamente:

I - decidirá se a ação tem condições de prosseguir na forma coletiva;

II - poderá separar os pedidos em ações coletivas distintas, voltadas à tutela, respectivamente, dos interesses ou direitos difusos e individuais homogêneos, desde que a separação represente economia processual ou facilite a condução do processo;

III - fixará os pontos controvertidos, decidirá as questões processuais pendentes e determinará as provas a serem produzidas, designando audiência de instrução e julgamento, se for o caso;

IV - esclarecerá os encargos das partes quanto à distribuição do ônus da prova, de acordo com o disposto no parágrafo $1^{\circ}$ do artigo 12 .

Art. 12. Provas - São admissíveis em juízo todos os meios de prova, desde que obtidos por meios lícitos, incluindo a prova estatística ou por amostragem.

Par. $1^{\circ}$. O ônus da prova incumbe à parte que detiver conhecimentos técnicos ou informações específicas sobre os fatos, ou maior facilidade em sua demonstração. Não obstante, se por razões de ordem econômica ou técnica, o ônus da prova não puder ser cumprido, o juiz determinará o que for necessário para suprir à deficiência e obter elementos probatórios indispensáveis para a sentença de mérito, podendo requisitar perícias à entidade pública cujo objeto estiver ligado à matéria em debate, condenado-se o demandado sucumbente ao reembolso. Se assim mesmo a prova não puder ser obtida, o juiz poderá ordenar sua realização, a cargo ao Fundo de Direitos Difusos e Individuais Homogêneos.

Par. $2^{\circ}$ - Durante a fase instrutória, surgindo modificação de fato ou de direito relevante para o julgamento da causa, o juiz poderá rever, em decisão motivada, a distribuição do ônus da prova, concedido à parte a quem for atribuída a incumbência prazo razoável para a produção da prova, observado o contraditório em relação à parte contrária.

Par. $3^{\circ}$ - O juiz poderá determinar de ofício a produção de provas, observado o contraditório.

Art.13. Julgamento antecipado do mérito - O juiz decidirá desde logo a demanda pelo mérito, quando não houver necessidade de produção de prova.

Parágrafo único. O juiz poderá decidir desde logo parte da demanda, quando não houver necessidade de produção de prova, sempre que isso não importe em prejulgamento direto ou indireto do litígio que continuar pendente de decisão, prosseguindo o processo para a instrução e julgamento em relação aos demais pedidos nos autos principais e a parte antecipada em autos complementares.

Art. 14. Legitimação à liqüidação e execução da sentença condenatória - Decorridos 60 (sessenta) dias da passagem em julgado da sentença de procedência, sem que o autor promova a liquidação ou execução, deverá fazê-lo o Ministério Público, quando se tratar de interesse público relevante, facultada igual iniciativa, em todos os casos, aos demais legitimados.

Art. 15. Custas e honorários - Nas ações coletivas de que trata este código, a sentença condenará o demandado, se vencido, nas custas, emolumentos, honorários periciais e quaisquer outras despesas, bem como em honorários de advogados.

Par. $1^{\circ}$. No cálculo dos honorários, o juiz levará em consideração a vantagem para o grupo, categoria ou classe, a quantidade e qualidade do trabalho desenvolvido pelo advogado e a complexidade da causa.

Par. $2^{\circ}$. Se o legitimado for pessoa física, sindicato ou associação, o juiz poderá fixar gratificação financeira quando sua atuação tiver sido relevante na condução e êxito da ação coletiva.

Par. $3^{\circ}$ - Os autores da ação coletiva não adiantarão custas, emolumentos, honorários periciais e quaisquer outras despesas, nem serão condenados, salvo comprovada má-fé, em honorários de advogados, custas e despesas processuais.

Par. $4^{\circ}$. O litigante de má-fé e os responsáveis pelos respectivos atos serão solidariamente condenados ao pagamento das despesas processuais, em honorários advocatícios e no décuplo das custas, sem prejuízo da responsabilidade por perdas e danos. 
Art. 16. Prioridade de processamento - O juiz deverá dar prioridade ao processamento da ação coletiva, quando haja manifesto interesse social evidenciado pela dimensão do dano ou pela relevância do bem jurídico a ser protegido.

Art. 17. Interrupcão da prescricão - A citação valida para ação coletiva interrompe o prazo de prescrição das pretensões individuais e transindividuais direta ou indiretamente relacionadas com a controvérsia, retroagindo o efeito à data da propositura da demanda.

Art.18. Efeitos da apelação - A apelação da sentença definitiva tem efeito meramente devolutivo, salvo quando a fundamentação for relevante e puder resultar à parte lesão grave e de difícil reparação, hipótese em que o juiz pode atribuir ao recurso efeito suspensivo.

Art.19. Execução definitiva e execuçaõ provisória - A execução é definitiva quando passada em julgado a sentença; e provisória, na pendência dos recursos cabíveis.

Par. $1^{0}$ - A execução provisória corre por conta e risco do exeqüente, que responde pelos prejuízos causados ao executado, em caso de reforma da sentença recorrida.

Par. $2^{\circ}$ - A execução provisória permite a prática de atos que importem em alienação do domínio ou levantamento do depósito em dinheiro.

Par. $3^{0}$ - A pedido do executado, o juiz pode suspender a execução provisória quando dela puder resultar lesão grave e de difícil reparação.

\section{Capítulo IV - Da ação coletiva para a defesa de interesses ou direitos individuais homogêneos}

Art 20. Acão coletiva de responsabilidade civil - Os legitimados poderão propor, em nome próprio e no interesse das vítimas ou seus sucessores, dentre outras (art. $4^{\circ}$ ), ação civil coletiva de responsabilidade pelos danos individualmente sofridos, de acordo com o disposto nos artigos seguintes.

Parágrafo único. A determinação dos interessados poderá ocorrer no momento da liquidação ou execução do julgado, não havendo necessidade de a petição inicial estar acompanhada da relação de membros do grupo, classe ou categoria. Conforme o caso, o juiz poderá determinar, ao réu ou a terceiro, a apresentação da relação e dados de pessoas que se enquadram no grupo, categoria ou classe.

Art. 21. Citacão e notificacões - Estando em termos a petição inicial, o juiz ordenará a citação do réu e a publicação de edital no órgão oficial, a fim de que os interessados possam intervir no processo como assistentes ou coadjuvantes.

Par. $1^{\circ}$ - Sem prejuízo da publicação do edital, o juiz determinará sejam os órgãos e entidades de defesa dos interesses ou direitos protegidos neste Código notificados da existência da demanda coletiva e de seu trânsito em julgado a fim de que cumpram o disposto no caput deste artigo.

Par. $2^{\circ}$ - Quando for possível a execução do julgado, ainda que provisória, ou estiver preclusa a decisão antecipatória dos efeitos da tutela pretendida, o juiz determinará a publicação de edital no órgão oficial, às custas do demandado, impondo-lhe, também, o dever de divulgar nova informação pelos meios de comunicação social, observado o critério da modicidade do custo. Sem prejuízo das referidas providências, o juízo providenciará a comunicação aos órgãos e entidades de defesa dos interesses ou direitos protegidos neste código, para efeito do disposto no parágrafo anterior.

Par. $3^{\circ}$-. Os intervenientes não poderão discutir suas pretensões individuais no processo coletivo de conhecimento.

Art. 22. Sentenca condenatória - Em caso de procedência do pedido, a condenação poderá ser genérica, fixando a responsabilidade do demandado pelos danos causados e o dever de indenizar.

Par. $1^{\mathbf{0}}$. Sempre que possível, o juiz calculará o valor da indenização individual devida a cada membro do grupo na própria ação coletiva

Par. $2^{\circ}$. Quando o valor dos danos individuais sofridos pelos membros do grupo for uniforme, prevalentemente uniforme ou puder ser reduzido a uma fórmula matemática, a sentença coletiva indicará o valor ou a fórmula de cálculo da indenização individual.

Par. $3^{\circ}$ - O membro do grupo que considerar que o valor da indenização individual ou a fórmula para seu cálculo diverso do estabelecido na sentença coletiva, poderá propor ação individual de liquidação. 
Art. 23. Liquidacão e execucão individuais - A liquidação e a execução de sentença poderão ser promovidas pela vítima e seus sucessores, assim como pelos legitimados à ação coletiva.

Parágrafo único. Na liquidação da sentença, que poderá ser promovida no foro do domicílio do liquidante, caberá a este provar, tão só, o dano pessoal, o nexo de causalidade e o montante da indenização.

Art 24. Execucão coletiva - A execução poderá ser coletiva, sendo promovida pelos legitimados à ação coletiva, abrangendo as vítimas cujas indenizações já tiverem sido fixadas em liquidação, sem prejuízo do ajuizamento de outras execuções.

Parágrafo único. A execução coletiva far-se-á com base em certidão das decisões de liquidação, da qual constará a ocorrência , ou não, do trânsito em julgado.

Art. 25. Do pagamento. O pagamento das indenizações ou o levantamento do depósito será feito pessoalmente aos beneficiários.

Artigo 26. Competência para a execução. É competente para a execução o juízo:

I - da liquidação da sentença ou da ação condenatória, no caso de execução individual;

II - da ação condenatória, quando coletiva a execução.

Art 27. Liquidação e execução pelos danos globalmente causados - Decorrido o prazo de um ano sem habilitação de interessados em número compatível com a gravidade do dano, poderão os legitimados do artigo $3^{\circ}$ promover a liquidação e execução coletiva da indenização devida pelos danos causados.

Parágrafo único. O valor da indenização será fixado de acordo com o dano globalmente causado, que será demonstrado por todas as provas admitidas em direito. Sendo a produção de provas difícil ou impossível, em razão da extensão do dano ou de sua complexidade, o valor da indenização será fixado por arbitramento.

(Suprimir - Par. $2^{\circ}$. Quando não for possível a identificação dos interessados, o produto da indenização reverterá para o Fundo de Direitos Difusos e Individuais Homogêneos.)

Art 28. Concurso de créditos - Em caso de concurso de créditos decorrentes de condenação de que trata o artigo $6^{\circ}$ e de indenizações pelos prejuízos individuais resultantes do mesmo evento danoso, estas terão preferência no pagamento.

Parágrafo único. Para efeito do disposto neste artigo, a destinação da

importância recolhida ao fundo ficará sustada enquanto pendentes de decisão de segundo grau as ações de indenização pelos danos individuais, salvo na hipótese de o patrimônio do devedor ser manifestamente suficiente para responder pela integralidade das dívidas.

Par. $2^{\circ}$. O produto da indenização reverterá para o fundo previsto no artigo $6^{\circ}$.

\section{Capítulo V - Da conexão, da litispendência e da coisa julgada}

Art. 29. Conexão - Se houver conexão entre as causas coletivas, ficará prevento o juízo que conheceu da primeira ação, podendo ao juiz, de ofício ou a requerimento da parte, determinar a reunião de todos os processos, mesmo que nestes não atuem integralmente os mesmos sujeitos processuais.

Art. 30. Litispendência - A primeira ação coletiva induz litispendência para as demais ações coletivas que tenham por objeto controvérsia sobre o mesmo bem jurídico, mesmo sendo diferentes o legitimado ativo e a causa de pedir.

Art. 31. Relacão entre acão coletiva e acões individuais - A ação coletiva não induz litispendência para as ações individuais, mas os efeitos da coisa julgada coletiva (art. 33) não beneficiarão os autores das ações individuais, se não for requerida sua suspensão no prazo de 30 (trinta) dias, a contar da ciência efetiva da ação coletiva.

Parágrafo único - Cabe ao demandado informar o juízo da ação individual sobre a existência de ação coletiva com o mesmo fundamento, sob pena de, não o fazendo, o autor individual beneficiar-se da coisa julgada coletiva mesmo no caso da demanda individual ser rejeitada.

Art. 32 - Conversão de acões individuais em acão coletiva - $O$ juiz, tendo conhecimento da existência de diversos processos individuais correndo contra o mesmo demandado, com o mesmo fundamento, notificará o 
Ministério Público e, na medida do possível, outros representantes adequados, a fim de que proponham, querendo, ação coletiva, ressalvada aos autores individuais a faculdade prevista no artigo anterior.

Art. 33. Coisa julgada - Nas ações coletivas de que trata este código, a sentença fará coisa julgada erga omnes, exceto se o pedido for julgado improcedente por insuficiência de provas, hipótese em que qualquer legitimado poderá intentar outra ação, com idêntico fundamento valendo-se de nova prova.

Par. $1^{\circ}$. Mesmo na hipótese de improcedência fundada nas provas produzidas, qualquer legitimado poderá intentar outra ação, com idêntico fundamento, quando surgir prova nova, superveniente, que não poderia ter sido produzida no processo.

Par. $2^{\circ}$ - Tratando-se de interesses ou direitos individuais homogêneos, em caso de improcedência do pedido, os interessados poderão propor ação de indenização a título individual.

Par. $3^{\circ}$. Os efeitos da coisa julgada nas ações em defesa de interesses ou direitos difusos não prejudicarão as ações de indenização por danos pessoalmente sofridos, propostas individualmente ou na forma prevista neste código, mas, se procedente o pedido, beneficiarão as vítimas e seus sucessores, que poderão proceder à liquidação e à execução, nos termos dos artigos 22 a 24.

Par. $4^{\circ}$. Aplica-se o disposto no parágrafo anterior à sentença penal condenatória.

Par. $5^{\circ}$. A competência territorial do órgão julgador não representará limitação para a coisa julgada erga omnes.

Art. 34. Relaç̃oes jurídicas continuativas - Nas relações jurídicas continuativas, se sobrevier modificação no estado de fato ou de direito, a parte poderá pedir a revisão do que foi estatuído por sentença.

\section{Capítulo VI - Da ação coletiva passiva}

Art. 35. Aç̃es contra o grupo, categoria ou classe - Qualquer espécie de ação pode ser proposta contra uma coletividade organizada ou que tenha representante adequado, nos termos do parágrafo $2^{\circ}$ do artigo $2^{\circ}$ deste código, e desde que o bem jurídico a ser tutelado seja transindividual (artigo $1^{\circ}$ ) e se revista de interesse social.

Art. 36 -Coisa julgada passiva: interesses ou direitos difusos - Quando se tratar de interesses ou direitos difusos, a coisa julgada atuará erga omnes, vinculando os membros do grupo, categoria ou classe.

Art. 37. Coisa julgada passiva: interesses ou direitos individuais homogêneos - Quando se tratar de interesses ou direitos individuais homogêneos, a coisa julgada atuará erga omnes no plano coletivo, mas a sentença de procedência não vinculará os membros do grupo, categoria ou classe, que poderão mover ações próprias ou defender-se no processo de execução para afastar a eficácia da decisão na sua esfera jurídica individual.

Parágrafo único - Quando a ação coletiva passiva for promovida contra o sindicato, como substituto processual da categoria, a coisa julgada terá eficácia erga omnes, vinculando individualmente todos os membros, mesmo em caso de procedência do pedido.

Art. 38 - Aplicacão complementar às acões passivas - Aplica-se complementariamente às ações coletivas passivas o disposto neste Código quanto às ações coletivas ativas, no que não for incompatível.

\section{Capítulo VII - Disposições finais}

Art. 39. Princípios de interpretacão - Este código será interpretado de forma aberta e flexível, compatível com a tutela coletiva dos interesses e direitos de que trata.

Art. 40. Especialização dos magistrados - Sempre que possível, as ações coletivas serão processadas e julgadas por magistrados especializados.

Art. 41. Aplicação subsidiárias das normas processuais gerais e especiais - Aplicam-se subsidiariamente, no que não forem incompatíveis, as disposições do Código de Processo Civil e legislação especial pertinente. 


\title{
ANEXO B \\ ANTEPROJETO DE CÓDIGO BRASILEIRO DE PROCESSOS COLETIVOS (UERJ/Unesa)
}

\author{
PARTE I - DAS AÇÕES COLETIVAS EM GERAL \\ Capítulo I - Da tutela coletiva
}

Art. $1^{\circ}$. Da tutela jurisdicional coletiva Para a defesa dos direitos e interesses difusos, coletivos e individuais homogêneos são admissíveis, além das previstas neste Código, todas as espécies de ações e provimentos capazes de propiciar sua adequada e efetiva tutela.

Art. $2^{\mathbf{0}}$. Objeto da tutela coletiva A ação coletiva será exercida para a tutela de:

I - interesses ou direitos difusos, assim entendidos os transindividuais, de natureza indivisível, de que sejam titulares pessoas indeterminadas e ligadas por circunstâncias de fato;

II - interesses ou direitos coletivos, assim entendidos os transindividuais, de natureza indivisível, de que seja titular um grupo, categoria ou classe de pessoas ligadas entre si ou com a parte contrária por uma relação jurídica base;

III - interesses ou direitos individuais homogêneos, assim entendidos os direitos subjetivos decorrentes de origem comum.

Parágrafo único - Não se admitirá ação coletiva que tenha como pedido a declaração de inconstitucionalidade, mas esta poderá ser objeto de questão prejudicial, pela via do controle difuso.

\section{Capítulo II - Dos pressupostos processuais e das condições da ação \\ Seção I - Do órgão judiciário}

Art. $3^{\mathbf{o}}$. Competência territorial É competente para a causa o foro do lugar onde ocorreu ou deva ocorrer o dano.

$\S 1^{\circ}$. Em caso de abrangência de mais de um foro, determinar-se-á a competência pela prevenção, aplicandose as regras pertinentes de organização judiciária.

$\S 2^{\circ}$. Em caso de dano de âmbito nacional, serão competentes os foros das capitais dos estados e do distrito federal.

Redação aprovada na UNESA: Art. $3^{\circ}$. Competência territorial É competente para a causa o foro do lugar onde ocorreu ou deva ocorrer o dano.

Parágrafo único. Em caso de abrangência de mais de um foro, determinar-se-á a competência pela prevenção, aplicando-se as regras pertinentes de organização judiciária.

Art. $4^{\mathbf{0}}$. Prioridade de processamento O juiz dará prioridade ao processamento da ação coletiva.

Art. $5^{0}$. Juízos especializados As ações coletivas serão processadas e julgadas em juízos especializados, quando existentes.

Art. $6^{\mathbf{0}}$. Conexão Se houver conexão entre causas coletivas, de qualquer espécie, ficará prevento o juízo perante o qual a demanda foi distribuída em primeiro lugar, devendo o juiz, de ofício ou a requerimento da parte, determinar a reunião de todos os processos, mesmo que nestes não atuem integralmente os mesmos sujeitos processuais.

\section{Seção II - Da litispendência e da continência}

Art. $\mathbf{7}^{\mathbf{0}}$. Litispendência e continência A primeira ação coletiva induz litispendência para as demais ações coletivas que tenham o mesmo pedido, causa de pedir e interessados.

$\S 1^{\circ}$. Estando o objeto da ação posteriormente proposta contido no da primeira, será extinto o processo ulterior sem o julgamento do mérito.

$\S 2^{\circ}$. Sendo o objeto da ação posteriormente proposta mais abrangente, o processo ulterior prosseguirá tão somente para a apreciação do pedido não contido na primeira demanda, devendo haver a reunião dos processos perante o juiz prevento em caso de conexão.

$\S 3^{\circ}$. Ocorrendo qualquer das hipóteses previstas neste artigo, as partes poderão requerer a extração ou remessa de peças processuais, com o objetivo de instruir o primeiro processo instaurado.

Seção III - Das condições específicas da ação coletiva e da legitimação ativa

Art. $8^{\circ}$. Requisitos específicos da ação coletiva São requisitos específicos da ação coletiva, a serem aferidos em decisão especificamente motivada pelo juiz: 
I - a adequada representatividade do legitimado;

II - a relevância social da tutela coletiva, caracterizada pela natureza do bem jurídico, pelas características da lesão ou pelo elevado número de pessoas atingidas.

$\S 1^{\circ}$. Na análise da representatividade adequada o juiz deverá examinar dados como:

a) a credibilidade, capacidade e experiência do legitimado;

b) seu histórico de proteção judicial e extrajudicial dos interesses ou direitos dos membros do grupo, categoria ou classe;

c) sua conduta em outros processos coletivos;

d) a coincidência entre os interesses do legitimado e o objeto da demanda;

e) o tempo de instituição da associação e a representatividade desta ou da pessoa física perante o grupo, categoria ou classe.

$\S 2^{\circ}$. O juiz analisará a existência do requisito da representatividade adequada a qualquer tempo e em qualquer grau do procedimento, aplicando, se for o caso, o disposto no parágrafo $3^{\circ}$. do artigo seguinte.

Art. $9^{0}$. Legitimação ativa. São legitimados concorrentemente à ação coletiva:

I - qualquer pessoa física, para a defesa dos direitos ou interesses difusos;

II - o membro do grupo, categoria ou classe, para a defesa dos direitos ou interesses coletivos e individuais homogêneos;

III - o Ministério Público, para a defesa dos direitos ou interesses difusos, coletivos e individuais homogêneos de interesse social;

IV - a Defensoria Pública, para a defesa dos direitos ou interesses difusos, coletivos e individuais homogêneos;

$\mathrm{V}$ - as pessoas jurídicas de direito público interno, para a defesa dos direitos ou interesses difusos e coletivos relacionados às suas funções;

VI - as entidades e órgãos da Administração Pública, direta ou indireta, ainda que sem personalidade jurídica, especificamente destinados à defesa dos direitos ou interesses protegidos por este código;

VII - as entidades sindicais, para a defesa dos direitos ou interesses difusos, coletivos e individuais homogêneos ligados à categoria;

VIII - os partidos políticos com representação no Congresso Nacional, nas Assembléias Legislativas ou nas Câmaras Municipais, conforme o âmbito do objeto da demanda, para a defesa de direitos e interesses ligados a seus fins institucionais;

IX - as associações legalmente constituídas e que incluam entre seus fins institucionais a defesa dos direitos ou interesses protegidos neste código, dispensada a autorização assemblear.

$\S 1^{\circ}$. Será admitido o litisconsórcio facultativo entre os legitimados.

$\S 2^{\circ}$. Em caso de interesse social, o Ministério Público, se não ajuizar a ação ou não intervier no processo como parte, atuará obrigatoriamente como fiscal da lei.

$\S 3^{\circ}$. Em caso de inexistência inicial ou superveniente do requisito da representatividade adequada, de desistência infundada ou abandono da ação, o juiz notificará o Ministério Público, observado o disposto no inciso III, e, na medida do possível, outros legitimados adequados para o caso, a fim de que assumam, querendo, a titularidade da ação. Havendo inércia do Ministério Público, aplica-se o disposto no parágrafo único do artigo 10 deste código.

Capítulo III - Da comunicação sobre processos repetitivos, do inquérito civil e do compromisso de ajustamento de conduta

Art. 10 Comunicação sobre processos repetitivos $\mathrm{O}$ juiz, tendo conhecimento da existência de diversos processos individuais correndo contra o mesmo demandado, com idêntico fundamento, comunicará o fato ao Ministério Público e, na medida do possível, a outros legitimados (art. $9^{\circ}$ ), a fim de que proponham, querendo, ação coletiva.

Parágrafo único - Caso o Ministério Público não promova a ação coletiva, no prazo de 90 (noventa) dias, fará a remessa do expediente recebido ao órgão com atribuição para a homologação ou rejeição da promoção de arquivamento do inquérito civil, para que, do mesmo modo, delibere em relação à propositura ou não da ação coletiva.

Art.11 Inquérito civil. O Ministério Público poderá instaurar, sob sua presidência, inquérito civil, nos termos do disposto em sua Lei Orgânica. 
$\S 1^{\circ}$. Se o órgão do Ministério Público, esgotadas todas as diligências, se convencer da inexistência de fundamento para a propositura da ação, promoverá o arquivamento dos autos do inquérito civil ou das peças informativas, fazendo-o fundamentadamente.

$\S 2^{\circ}$. Os autos do inquérito civil ou das peças informativas arquivadas serão remetidos, sob pena de se incorrer em falta grave, no prazo de 10 (dez) dias, ao órgão com atribuição para homologação, na forma da Lei Orgânica.

$\S 3^{\circ}$. Até que, em sessão do órgão com atribuição para homologação, seja homologada ou rejeitada a promoção, poderão os interessados apresentar razões escritas e documentos, que serão juntados aos autos do inquérito ou anexados às peças de informação.

$\S 4^{\circ}$. Deixando o órgão com atribuição de homologar a promoção de arquivamento, designará, desde logo, outro membro do Ministério Público para o ajuizamento da ação.

Art. 12 Compromisso de ajustamento de conduta O Ministério Público e os órgãos públicos legitimados poderão tomar dos interessados compromisso de ajustamento de conduta às exigências legais, mediante cominações, que terá eficácia de título executivo extrajudicial, sem prejuízo da possibilidade de homologação judicial do compromisso, se assim requererem as partes.

Parágrafo único - Quando o compromisso de ajustamento for tomado por legitimado que não seja o Ministério Público, este deverá ser cientificado para que funcione como fiscal.

\section{Capítulo IV - Da postulação}

Art. 13 Custas e honorários Os autores da ação coletiva não adiantarão custas, emolumentos, honorários periciais e quaisquer outras despesas, nem serão condenados, salvo comprovada má-fé, em honorários de advogados, custas e despesas processuais.

$\S 1^{\circ}$. Nas ações coletivas de que trata este código, a sentença condenará o demandado, se vencido, nas custas, emolumentos, honorários periciais e quaisquer outras despesas, bem como em honorários de advogados.

$\S 2^{\circ}$. No cálculo dos honorários, o juiz levará em consideração a vantagem para o grupo, categoria ou classe, a quantidade e qualidade do trabalho desenvolvido pelo advogado e a complexidade da causa.

$\S 3^{\circ}$. Se o legitimado for pessoa física, sindicato ou associação, o juiz poderá fixar gratificação financeira quando sua atuação tiver sido relevante na condução e êxito da ação coletiva.

$\S 4^{\circ}$ O litigante de má-fé e os responsáveis pelos respectivos atos serão solidariamente condenados ao pagamento das despesas processuais, em honorários advocatícios e até o décuplo das custas, sem prejuízo da responsabilidade por perdas e danos.

Art. 14 Da instrução da inicial Para instruir a inicial, o legitimado, sem prejuízo das prerrogativas do Ministério Público, poderá requerer às autoridades competentes as certidões e informações que julgar necessárias.

$\S 1^{\circ}$. As certidões e informações deverão ser fornecidas dentro de 15 (quinze) dias da entrega, sob recibo, dos respectivos requerimentos, e só poderão ser utilizadas para a instrução da ação coletiva.

$\S 2^{\circ}$. Somente nos casos em que o sigilo for exigido para a defesa da intimidade ou do interesse social poderá ser negada a certidão ou informação.

$\S 3^{\circ}$. Ocorrendo a hipótese do parágrafo anterior, a ação poderá ser proposta desacompanhada das certidões ou informações negadas, cabendo ao juiz, após apreciar os motivos do indeferimento, requisitá-las; feita a requisição, o processo correrá em segredo de justiça.

Art. 15 Pedido O juiz permitirá, até a decisão saneadora, a ampliação ou adaptação do objeto do processo, desde que, realizada de boa-fé, não represente prejuízo injustificado à parte contrária, à celeridade e ao bom andamento do processo e o contraditório seja preservado.

Art 16 Contraditório para as medidas antecipatórias Para a concessão de liminar ou de tutela antecipada nas ações coletivas, o juiz poderá ouvir, se entender conveniente e não houver prejuízo para a efetividade da medida, a parte contrária, que deverá se pronunciar no prazo de 72 (setenta e duas) horas.

Art. 17 Efeitos da citação A citação válida para a ação coletiva interrompe o prazo de prescrição das pretensões individuais e transindividuais relacionadas com a controvérsia, retroagindo o efeito à data da propositura da demanda.

Art. 18 Audiência preliminar Encerrada a fase postulatória, o juiz designará audiência preliminar, à qual comparecerão as partes ou seus procuradores, habilitados a transigir.

$\S 1^{\circ}$. O juiz ouvirá as partes sobre os motivos e fundamentos da demanda e tentará a conciliação, sem prejuízo de sugerir outras formas adequadas de solução do conflito, como a mediação, a arbitragem e a avaliação neutra de terceiro. 
$\S 2^{\circ}$. A avaliação neutra de terceiro, de confiança das partes, obtida no prazo fixado pelo juiz, é sigilosa, inclusive para esse, e não vinculante para as partes, sendo sua finalidade exclusiva a de orientá-las na tentativa de composição amigável do conflito.

$\S 3^{\circ}$. Preservada a indisponibilidade do bem jurídico coletivo, as partes poderão transigir sobre o modo de cumprimento da obrigação.

$\S 4^{\circ}$. Obtida a transação, será homologada por sentença, que constituirá título executivo judicial.

$\S 5^{\circ}$. Não obtida a conciliação, sendo ela parcial, ou quando, por qualquer motivo, não for adotado outro meio de solução do conflito, o juiz, fundamentadamente:

I - decidirá se a ação tem condições de prosseguir na forma coletiva, certificando-a como coletiva;

II - poderá separar os pedidos em ações coletivas distintas, voltadas à tutela, respectivamente, dos interesses ou direitos difusos, coletivos e individuais homogêneos, desde que a separação represente economia processual ou facilite a condução do processo;

III - fixará os pontos controvertidos, decidirá as questões processuais pendentes e determinará as provas a serem produzidas, designando audiência de instrução e julgamento, se for o caso;

IV - esclarecerá os encargos das partes quanto à distribuição do ônus da prova, de acordo com o disposto no parágrafo $1^{\circ}$. do artigo seguinte.

\section{Capítulo V - Da prova}

Art. 19 Provas São admissíveis em juízo todos os meios de prova, desde que obtidos por meios lícitos, incluindo a prova estatística ou por amostragem.

$\S 1^{\circ}$. O ônus da prova incumbe à parte que detiver conhecimentos técnicos ou informações específicas sobre os fatos, ou maior facilidade em sua demonstração, cabendo ao juiz deliberar sobre a distribuição do ônus da prova por ocasião da decisão saneadora.

$\S 2^{\circ}$. Durante a fase instrutória, surgindo modificação de fato ou de direito relevante para o julgamento da causa, o juiz poderá rever, em decisão motivada, a distribuição do ônus da prova, concedendo à parte a quem for atribuída a incumbência prazo razoável para a produção da prova, observado o contraditório em relação à parte contrária.

$\S 3^{\circ}$. O juiz poderá determinar de ofício a produção de provas, observado o contraditório.

\section{Capítulo VI - Do julgamento, do recurso e da coisa julgada}

Art. 20 Motivação das decisões judiciárias Todas as decisões deverão ser especificamente fundamentadas, especialmente quanto aos conceitos jurídicos indeterminados.

Parágrafo único Na sentença de improcedência, o juiz deverá explicitar, no dispositivo, se rejeita a demanda por insuficiência de provas.

Art. 21 Efeitos do recurso da sentença $O$ recurso interposto contra a sentença tem efeito meramente devolutivo, salvo quando a fundamentação for relevante e puder resultar à parte lesão grave e de difícil reparação, hipótese em que o juiz pode atribuir ao recurso efeito suspensivo.

Art. 22 Coisa julgada Nas ações coletivas a sentença fará coisa julgada erga omnes, salvo quando o pedido for julgado improcedente por insuficiência de provas.

$\S 1^{\circ}$. Os efeitos da coisa julgada para a defesa de interesses difusos e coletivos em sentido estrito ficam adstritos ao plano coletivo, não prejudicando interesses e direitos individuais homogêneos reflexos.

$\S 2^{\circ}$. Os efeitos da coisa julgada em relação aos interesses ou direitos difusos e coletivos não prejudicarão as ações de indenização por danos pessoalmente sofridos, propostas coletiva ou individualmente, mas, se procedente o pedido, beneficiarão as vítimas e seus sucessores, que poderão proceder à liquidação e à execução, nos termos do art.37 e seguintes.

$\S 3^{\circ}$. Na hipótese dos interesses ou direitos individuais homogêneos, apenas não estarão vinculados ao pronunciamento coletivo os titulares de interesses ou direitos que tiverem exercido tempestiva e regularmente o direito de ação ou exclusão.

$\S 4^{\circ}$. A competência territorial do órgão julgador não representará limitação para a coisa julgada erga omnes.

\section{Capítulo VII - Das obrigações específicas}

Art. 23 Obrigações de fazer e não fazer Na ação que tenha por objeto o cumprimento da obrigação de fazer ou não fazer, o juiz concederá a tutela específica da obrigação ou determinará providências que assegurem o resultado prático equivalente ao do adimplemento. 
$\S 1^{\circ}$. O juiz poderá, na hipótese de antecipação de tutela ou na sentença, impor multa diária ao demandado, independentemente de pedido do autor, se for suficiente ou compatível com a obrigação, fixando prazo razoável para o cumprimento do preceito.

$\S 2^{\circ}$. O juiz poderá, de ofício, modificar o valor ou a periodicidade da multa, caso verifique que se tornou insuficiente ou excessiva.

$\S 3^{\circ}$. Para a tutela específica ou para a obtenção do resultado prático equivalente, poderá o juiz determinar as medidas necessárias, tais como busca e apreensão, remoção de coisas e pessoas, desfazimento de obra, impedimento de atividade nociva, além da requisição de força policial.

$\S 4^{\circ}$. A conversão da obrigação em perdas e danos somente será admissível se por elas optar o autor ou se impossível a tutela específica ou a obtenção do resultado prático correspondente.

$\S 5^{\circ}$. A indenização por perdas e danos se fará sem prejuízo da multa.

Art. 24 Obrigações de dar $\mathrm{Na}$ ação que tenha por objeto a obrigação de entregar coisa, determinada ou indeterminada, aplicam-se, no que couber, as disposições do artigo anterior.

Art. 25 Ação indenizatória Na ação condenatória à reparação dos danos provocados ao bem indivisivelmente considerado, a indenização reverterá ao Fundo dos Direitos Difusos, Coletivos e Individuais Homogêneos, de natureza federal ou estadual, de acordo com o bem ou interesse afetado.

$\S 1^{\circ}$. Dependendo da especificidade do bem jurídico afetado, da extensão territorial abrangida e de outras circunstâncias consideradas relevantes, o juiz poderá especificar, em decisão fundamentada, a destinação da indenização e as providências a serem tomadas para a reconstituição dos bens lesados, podendo indicar a realização de atividades tendentes a minimizar a lesão ou a evitar que se repita, dentre outras que beneficiem o bem jurídico prejudicado.

$\S 2^{\circ}$. A decisão que especificar a destinação da indenização indicará, de modo claro e preciso, as medidas a serem tomadas pelo Conselho Gestor do Fundo, bem como um prazo razoável para que tais medidas sejam concretizadas.

$\S 3^{\circ}$. Vencido o prazo fixado pelo juiz, o Conselho Gestor do Fundo apresentará relatório das atividades realizadas, facultada, conforme o caso, a solicitação de sua prorrogação, para completar as medidas determinadas na decisão judicial.

$\S 4^{\circ}$. Aplica-se ao descumprimento injustificado dos parágrafos $2^{\circ}$. e $3^{\circ}$. o disposto no parágrafo $2^{\circ}$. do artigo 29.

\section{Capítulo VIII - Da liquidação e da execução}

Art. 26 Legitimação à liquidação e execução da sentença condenatória Decorridos 60 (sessenta) dias da passagem em julgado da sentença de procedência, sem que o autor da ação coletiva promova a liquidação ou execução coletiva, deverá fazê-lo o Ministério Público, quando se tratar de interesse público, facultada igual iniciativa, em todos os casos, aos demais legitimados.

Art. 27 Execução definitiva e execução provisória A execução é definitiva quando passada em julgado a sentença; e provisória, na pendência dos recursos cabíveis.

$\S 1^{\circ}$. A execução provisória corre por conta e risco do exeqüente, que responde pelos prejuízos causados ao executado, em caso de reforma da sentença recorrida.

$\S 2^{\circ}$. A execução provisória não impede a prática de atos que importem em alienação do domínio ou levantamento do depósito em dinheiro.

$\S 3^{\circ}$. A pedido do executado, o juiz pode suspender a execução provisória quando dela puder resultar lesão grave e de difícil reparação.

Capítulo IX - Do cadastro nacional de processos coletivos e do Fundo de Direitos Difusos, Coletivos e Individuais Homogêneos

Art. 28 Cadastro nacional de processos coletivos O Conselho Nacional de Justiça organizará e manterá o cadastro nacional de processos coletivos, com a finalidade de permitir que todos os órgãos do Poder Judiciário e todos os interessados tenham conhecimento da existência das ações coletivas, facilitando a sua publicidade e o exercício do direito de exclusão.

$\S 1^{\circ}$. Os órgãos judiciários aos quais forem distribuídas ações coletivas remeterão, no prazo de dez dias, cópia da petição inicial ao cadastro nacional de processos coletivos.

$\S 2^{\circ}$. O Conselho Nacional de Justiça editará regulamento dispondo sobre o funcionamento do cadastro nacional de processos coletivos, em especial a forma de comunicação pelos juízos quanto à existência das ações coletivas e aos atos processuais mais relevantes, como a concessão de antecipação de tutela, a sentença 
e o trânsito em julgado; disciplinará, ainda, sobre os meios adequados a viabilizar o acesso aos dados e o acompanhamento daquelas por qualquer interessado.

Art. 29 Fundo dos Direitos Difusos, Coletivos e Individuais Homogêneos O fundo será administrado por um Conselho Federal ou por Conselhos Estaduais, de que participarão necessariamente membros do Ministério Público, juízes e representantes da comunidade, sendo seus recursos destinados à reconstituição dos bens lesados ou, não sendo possível, à realização de atividades tendentes a minimizar a lesão ou a evitar que se repita, dentre outras que beneficiem o bem jurídico prejudicado.

$\S 1^{\circ}$. Além da indenização oriunda de sentença condenatória, nos termos do disposto no caput do art. 25 , constituem também receitas do Fundo o produto da arrecadação de multas judiciais e da indenização devida quando não for possível o cumprimento da obrigação pactuada em termo de ajustamento de conduta.

$\S 2^{\circ}$. O representante legal do Fundo, considerado servidor público para efeitos legais, responderá por sua atuação nas esferas administrativa, penal e civil.

$\S 3^{\circ}$. O Fundo será notificado da propositura de toda ação coletiva e da decisão final do processo.

$\S 4^{\circ}$. O Fundo manterá e divulgará registros que especifiquem a origem e a destinação dos recursos e indicará a variedade dos bens jurídicos a serem tutelados e seu âmbito regional.

$\S 5^{\circ}$. Semestralmente, o Fundo dará publicidade às suas demonstrações financeiras e atividades desenvolvidas.

\section{PARTE II - DAS AÇÕES COLETIVAS PARA A DEFESA DOS DIREITOS OU INTERESSES INDIVIDUAIS HOMOGÊNEOS}

Art. 30 Da ação coletiva para a defesa dos direitos ou interesses individuais homogêneos Para a tutela dos interesses ou direitos individuais homogêneos, além dos requisitos indicados no art. $8^{\circ}$. deste Código, é necessária a aferição da predominância das questões comuns sobre as individuais e da utilidade da tutela coletiva no caso concreto.

Art. 31 Determinação dos interessados A determinação dos interessados poderá ocorrer no momento da liquidação ou execução do julgado, não havendo necessidade de a petição inicial estar acompanhada da relação dos membros do grupo, classe ou categoria. Conforme o caso, poderá o juiz determinar, ao réu ou a terceiro, a apresentação da relação e dados de pessoas que se enquadram no grupo, categoria ou classe.

Art. 32 Citação e notificações Estando em termos a petição inicial, o juiz ordenará a citação do réu, a publicação de edital no órgão oficial e a comunicação dos interessados, titulares dos direitos ou interesses individuais homogêneos objeto da ação coletiva, para que possam exercer no prazo fixado seu direito de exclusão em relação ao processo coletivo, sem prejuízo de ampla divulgação pelos meios de comunicação social.

$\S 1^{\circ}$. Não sendo fixado pelo juiz o prazo acima mencionado, o direito de exclusão poderá ser exercido até a publicação da sentença no processo coletivo.

$\S 2^{\circ}$. A comunicação prevista no caput poderá ser feita pelo correio, por oficial de justiça, por edital ou por inserção em outro meio de comunicação ou informação, como contracheque, conta, fatura, extrato bancário e outros, sem obrigatoriedade de identificação nominal dos destinatários, que poderão ser caracterizados enquanto titulares dos mencionados interesses, fazendo-se referência à ação e às partes, bem como ao pedido e à causa de pedir, observado o critério da modicidade do custo.

Art. 33 Relação entre ação coletiva e ações individuais $\mathrm{O}$ ajuizamento ou prosseguimento da ação individual versando sobre direito ou interesse que esteja sendo objeto de ação coletiva pressupõe a exclusão tempestiva e regular desta.

$\S 1^{\circ}$. O ajuizamento da ação coletiva ensejará a suspensão, por trinta dias, a contar da ciência efetiva desta, dos processos individuais em tramitação que versem sobre direito ou interesse que esteja sendo objeto no processo coletivo.

$\S 2^{\circ}$. Dentro do prazo previsto no parágrafo anterior, os autores das ações individuais poderão requerer, nos autos do processo individual, sob pena de extinção sem julgamento do mérito, que os efeitos das decisões proferidas na ação coletiva não lhes sejam aplicáveis, optando, assim, pelo prosseguimento do processo individual.

$\S 3^{\circ}$. Os interessados que, quando da comunicação, não possuírem ação individual ajuizada e não desejarem ser alcançados pelos efeitos das decisões proferidas na ação coletiva poderão optar entre o requerimento de exclusão ou o ajuizamento da ação individual no prazo assinalado, hipótese que equivalerá à manifestação expressa de exclusão. 
$\S 4^{\circ}$. Não tendo o juiz deliberado acerca da forma de exclusão, esta ocorrerá mediante simples manifestação dirigida ao juiz do respectivo processo coletivo ou ao órgão incumbido de realizar a nível nacional o registro das ações coletivas, que poderão se utilizar eventualmente de sistema integrado de protocolo.

$\S 5^{\circ}$. O requerimento de exclusão, devida e tempestivamente protocolizado, consistirá em documento indispensável para a propositura de ulterior demanda individual.

Art. 34 Assistência Os titulares dos direitos ou interesses individuais homogêneos poderão intervir no processo como assistentes, sendo-lhes vedado discutir suas pretensões individuais no processo coletivo de conhecimento.

Art. 35 Efeitos da transação As partes poderão transacionar, ressalvada aos membros do grupo, categoria ou classe a faculdade de se desvincularem da transação, dentro do prazo fixado pelo juiz.

Parágrafo único - Os titulares dos direitos ou interesses individuais homogêneos serão comunicados, nos termos do art. 32, para que possam exercer o seu direito de exclusão, em prazo não inferior a 60 (sessenta) dias.

Art. 36 Sentença condenatória Sempre que possível, em caso de procedência do pedido, o juiz fixará na sentença do processo coletivo o valor da indenização individual devida a cada membro do grupo, categoria ou classe.

$\S 1^{\circ}$. Quando o valor dos danos sofridos pelos membros do grupo, categoria ou classe for uniforme, prevalentemente uniforme ou puder ser reduzido a uma fórmula matemática, a sentença coletiva indicará o valor ou a fórmula do cálculo da indenização individual.

$\S 2^{\circ}$. Não sendo possível a prolação de sentença coletiva líquida, a condenação poderá ser genérica, fixando a responsabilidade do demandado pelos danos causados e o dever de indenizar.

Art. 37 Competência para a liquidação e a execução É competente para a liquidação e a execução o juízo:

I - da ação condenatória, quando coletiva a liquidação ou a execução;

II - do domicílio do demandado ou do demandante individual, no caso de liquidação ou execução individual.

Art. 38 Liquidação e execução coletivas Sempre que possível, a liquidação e a execução serão coletivas, sendo promovidas pelos legitimados à ação coletiva.

Art. 39 Pagamento Quando a execução for coletiva, os valores destinados ao pagamento das indenizações individuais serão depositados em instituição bancária oficial, abrindo-se conta remunerada e individualizada para cada beneficiário; os respectivos saques, sem expedição de alvará, reger-se-ão pelas normas aplicáveis aos depósitos bancários e estarão sujeitos à retenção de imposto de renda na fonte, nos termos da lei.

Art. 40 Liquidação e execução individuais Quando não for possível a liquidação coletiva, a fixação dos danos e respectiva execução poderão ser promovidas individualmente.

$\S 1^{\circ}$. Na liquidação de sentença, caberá ao liquidante provar, tão só, o dano pessoal, o nexo de causalidade e o montante da indenização.

$\S 2^{\circ}$. Decorrido o prazo de um ano sem que tenha sido promovido um número de liquidações individuais compatível com a gravidade do dano, poderão os legitimados coletivos promover a liquidação e a execução coletiva da indenização devida pelos danos causados, hipótese em que:

I - O prazo previsto neste parágrafo prevalece sobre os prazos prescricionais aplicáveis à execução da sentença;

II - O valor da indenização será fixado de acordo com o dano globalmente causado, que será demonstrado por todas as provas admitidas em direito. Sendo a produção de provas difícil ou impossível, em razão da extensão do dano ou de sua complexidade, o valor da indenização será fixado por arbitramento;

III - Quando não for possível a identificação dos interessados, o produto da indenização reverterá para o Fundo dos Direitos Difusos, Coletivos e Individuais Homogêneos.

Art. 41 Concurso de créditos Em caso de concurso de créditos decorrentes de condenação de que trata o artigo 25 e de indenizações pelos prejuízos individuais resultantes do mesmo evento danoso, estes terão preferência no pagamento.

Parágrafo único - Para efeito do disposto neste artigo, a destinação da importância recolhida ao Fundo ficará sustada enquanto pendentes de decisão de segundo grau as ações de indenização pelos danos individuais, salvo na hipótese de o patrimônio do devedor ser manifestamente suficiente para responder pela integralidade das dívidas. 


\section{PARTE III - DA AÇÃO COLETIVA PASSIVA}

Art. 42 Ação contra o grupo, categoria ou classe Qualquer espécie de ação pode ser proposta contra uma coletividade organizada ou que tenha representante adequado, nos termos do parágrafo $1^{\circ}$. do artigo $8^{\circ}$, e desde que o bem jurídico a ser tutelado seja transindividual (art. $2^{\circ}$.) e se revista de interesse social.

Art. 43 Coisa julgada passiva A coisa julgada atuará erga omnes, vinculando os membros do grupo, categoria ou classe.

Art. 44 Aplicação complementar à ação coletiva passiva Aplica-se complementarmente à ação coletiva passiva o disposto neste código quanto à ação coletiva ativa, no que não for incompatível.

\section{PARTE IV - PROCEDIMENTOS ESPECIAIS}

\section{Capítulo I - Do mandado de segurança coletivo}

Art. 45 Cabimento Conceder-se-á mandado de segurança coletivo, nos termos dos incisos LXIX e LXX do artigo $5^{\circ}$. da Constituição Federal, para proteger direito líquido e certo relativo a interesses ou direitos difusos, coletivos ou individuais homogêneos (art. $2^{\circ}$.).

Art. 46 Disposições aplicáveis Aplica-se ao mandado de segurança coletivo o disposto neste código, inclusive no tocante às custas e honorários (art. 16), e na lei 1533/51, no que não for incompatível.

\section{Capítulo II - Do mandado de injunção coletivo}

Art. 47 Cabimento Conceder-se-á mandado de injunção coletivo sempre que a falta de norma regulamentadora torne inviável o exercício dos direitos e liberdades constitucionais e das prerrogativas inerentes à nacionalidade, à soberania, à cidadania, relativamente a direitos ou interesses difusos, coletivos e individuais homogêneos.

Art. 48 Competência É competente para processar e julgar o mandado de injunção coletivo:

I - o Supremo Tribunal Federal, quando a elaboração da norma regulamentadora for atribuição do Presidente da República, do Congresso Nacional, da Câmara dos Deputados, do Senado Federal, da Mesa de uma dessas Casas Legislativas, do Tribunal de Contas da União, de um dos Tribunais Superiores, ou do próprio Supremo Tribunal Federal.

Parágrafo Único - Compete também ao Supremo Tribunal Federal julgar, em recurso ordinário, o mandado de injunção decidido em única ou última instância pelos Tribunais Superiores, se denegatória a decisão.

II - o Superior Tribunal de Justiça, quando a elaboração da norma regulamentadora for atribuição de órgão, entidade ou autoridade federal, da administração direta ou indireta, excetuados os casos de competência do Supremo Tribunal Federal e dos órgãos da Justiça Militar, da Justiça Eleitoral, da Justiça do Trabalho e da Justiça Federal.

III - O Tribunal de Justiça dos Estados e do Distrito Federal, quando a elaboração da norma regulamentadora for atribuição de Governador, Assembléia Legislativa, Tribunal de Contas local, do próprio Tribunal de Justiça, de órgão, entidade ou autoridades estadual ou distrital, da administração direta ou indireta.

Art. 49 Legitimação passiva $\mathrm{O}$ mandado de injunção coletivo será impetrado, em litisconsórcio obrigatório, em face da autoridade ou órgão público competente para a edição da norma regulamentadora; e ainda da pessoa física ou jurídica, de direito público ou privado, que, por inexistência de norma regulamentadora, impossibilite o exercício dos direitos e liberdades constitucionais relativos a interesses ou direitos difusos, coletivos ou individuais homogêneos.

Art. 50 Edição superveniente da norma regulamentadora Se a norma regulamentadora for editada no curso do mandado de injunção coletivo, o órgão jurisdicional apurará acerca da existência ainda de matéria não regulada, referente a efeitos pretéritos do dispositivo constitucional tardiamente regulado, prosseguindo, se for a hipótese, para julgamento da parte remanescente.

$\S 1^{\circ}$ Dispondo a norma regulamentadora editada no curso do mandado de injunção coletivo inclusive quanto ao período em que se verificara a omissão legislativa constitucionalmente relevante, o processo será extinto sem julgamento do mérito, nos termos do art. 267, VI do Código de Processo Civil, ficando o autor coletivo dispensando do pagamento de custas, despesas e honorários advocatícios.

$\S 2^{\circ}$ A norma regulamentadora, editada após o ajuizamento do mandado de injunção coletivo, respeitará os efeitos de eventual decisão judicial provisória ou definitiva proferida, mas será aplicada às projeções futuras da relação jurídica objeto de apreciação jurisdicional.

Art. 51 Sentença A sentença que conceder o mandado de injunção coletivo:

I - comunicará a caracterização da mora legislativa constitucionalmente qualificada ao Poder competente, para a adoção, no prazo que fixar, das providências necessárias; 
II - formulará, com base na equidade, a norma regulamentadora e, no mesmo julgamento, a aplicará ao caso concreto, determinando as obrigações a serem cumpridas pelo legitimado passivo para o efetivo exercício das liberdades e prerrogativas constitucionais dos integrantes do grupo, categoria ou classe.

$\S 1^{\circ}$ A parcela do dispositivo que se revista do conteúdo previsto no inciso II se prolata sob condição suspensiva, a saber, transcurso in albis do prazo assinalado a teor do inciso I, para superação da omissão legislativa constitucionalmente relevante reconhecida como havida.

$\S 2^{\circ} \mathrm{Na}$ sentença, o juiz poderá fixar multa diária para o réu que incida, eventualmente, em descumprimento da norma regulamentadora aplicada ao caso concreto, independentemente do pedido do autor.

Art. 52 Disposições aplicáveis Aplica-se ao mandado de injunção coletivo o disposto neste código, inclusive no tocante às custas e honorários (art. 16), quando compatível.

\section{Capítulo III - Da ação popular}

Art. 53 Disposições aplicáveis Aplica-se à ação popular o disposto na lei 4717/65, bem como o previsto neste código, no que for compatível.

\section{Capítulo IV - Da ação de improbidade administrativa}

Art. 54 Disposições aplicáveis Aplica-se à ação de improbidade administrativa o disposto na lei 8429/92, bem como o previsto neste código, no que for compatível.

\section{PARTE V - DISPOSIÇÕES FINAIS}

Art. 55 Princípios de interpretação Este código será interpretado de forma aberta e flexível, compatível com a tutela coletiva dos interesses e direitos de que trata.

Art. 56 Aplicação subsidiária do Código de Processo Civil Aplicam-se subsidiariamente às ações coletivas, no que não forem incompatíveis, as disposições do Código de Processo Civil.

Art. 57 Nova redação Dê-se nova redação aos artigos de leis abaixo indicados:

a) o inciso VIII do artigo $6^{\circ}$. da lei $8078 / 90$ passa a ter a seguinte redação:

art. $6^{\circ}$. inciso VIII - a facilitação da defesa dos seus direitos, incumbindo o ônus da prova à parte que detiver conhecimentos técnicos ou informações sobre os fatos, ou maior facilidade em sua demonstração.

b) o artigo 80 da lei 10741/2003 passa a ter a seguinte redação:

art. 80 - as ações individuais movidas pelo idoso poderão ser propostas no foro do seu domicílio.

Art. 58 Revogação Revogam-se a Lei 7347, de 24 de julho de 1985; os artigos 81 a 104 da Lei 8078/90, de 11 de setembro de 1990; o parágrafo $3^{\circ}$ do artigo $5^{\circ}$ da Lei 4717, de 29 de junho de 1965; os artigos $3^{\circ}, 4^{\circ}, 5^{\circ}$, $6^{\circ}$ e $7^{\circ}$ da Lei 7853, de 24 de outubro de 1989; o artigo $3^{\circ}$ da Lei 7913, de 7 de dezembro de 1989; os artigos $210,211,212,213,215,217,218,219,222,223$ e 224 da Lei 8069, de 13 de junho de 1990; o artigo $2^{\circ} \mathrm{A}$ da Lei 9494 , de 10 de setembro de 1997; e os artigos 81, 82, 83, 85, 91, 92 e 93 da Lei 10741 , de $1^{\circ}$ de outubro de 2003.

Art. 59 Instalação dos órgãos especializados A União, no prazo de um ano, a contar da publicação deste código, e os Estados criarão e instalarão órgãos especializados, em primeira e segunda instância, para o processamento e julgamento de ações coletivas.

Art. 60 Vigência Este código entrará em vigor dentro de um ano a contar de sua publicação. 


\section{ANEXO C \\ ANTEPROJETO DE \\ CÓDIGO BRASILEIRO DE PROCESSOS COLETIVOS (USP)}

\section{Capítulo I - Das demandas coletivas}

Art. $1^{\circ}$ Conteúdo do Código - Este Código dispõe sobre os processos coletivos relativos às ações coletivas ativas, à ação coletiva passiva originária, ao mandado de segurança coletivo, à ação popular constitucional e à ação de improbidade administrativa.

Art. $2^{\circ}$. Princípios da tutela jurisdicional coletiva - São princípios da tutela jurisdicional coletiva:

a. acesso à justiça e à ordem jurídica justa;

b. universalidade da jurisdição;

c. participação pelo processo e no processo;

d. tutela coletiva adequada;

e. boa-fé e cooperação das partes e de seus procuradores;

f. cooperação dos órgãos públicos na produção da prova;

g. economia processual;

h. instrumentalidade das formas;

i. ativismo judicial;

j. flexibilização da técnica processual;

k. dinâmica do ônus da prova;

1. representatividade adequada;

m. intervenção do Ministério Público em casos de relevante interesse social;

n. não taxatividade da ação coletiva;

o. ampla divulgação da demanda e dos atos processuais;

p. indisponibilidade temperada da ação coletiva;

q. continuidade da ação coletiva;

r. obrigatoriedade do cumprimento e da execução da sentença;

s. extensão subjetiva da coisa julgada, coisa julgada secundum eventum litis e secundum probationem;

t. reparação dos danos materiais e morais;

u. aplicação residual do Código de Processo Civil;

v. proporcionalidade e razoabilidade.

Art. $3^{\mathbf{0}}$ Efetividade da tutela jurisdicional - Para a defesa dos direitos e interesses indicados neste Código são admissíveis todas as espécies de ações e provimentos capazes de propiciar sua adequada e efetiva tutela, inclusive os previstos no Código de Processo Civil e em leis especiais.

$\S \mathbf{1}^{0} \mathrm{O}$ juiz, instaurado o contraditório, poderá desconsiderar a pessoa jurídica, nas hipóteses previstas no artigo 50 Código Civil e no artigo $4^{\circ}$ da Lei n. 9.605/98.

$\$ \mathbf{2}^{\mathbf{0}}$ Para a tutela dos interesses e direitos previstos nas alíneas II e III do artigo $3^{\mathbf{0}}$ e observada a disponibilidade do bem jurídico protegido, as partes poderão estipular convenção de arbitragem, a qual se regerá pelas disposições do Código de Processo Civil e da Lei n. 9.307, de 23 de setembro de 1996.

Art. $4^{\circ}$ Objeto da tutela coletiva - A demanda coletiva será exercida para a tutela de:

I - interesses ou direitos difusos, assim entendidos os transindividuais, de natureza indivisível, de que sejam titulares pessoas indeterminadas e ligadas por circunstâncias de fato;

II - interesses ou direitos coletivos, assim entendidos os transindividuais, de natureza indivisível, de que seja titular um grupo, categoria ou classe de pessoas ligadas, entre si ou com a parte contrária, por uma relação jurídica base;

III - interesses ou direitos individuais homogêneos, assim entendidos os decorrentes de origem comum.

Parágrafo único. A análise da constitucionalidade ou inconstitucionalidade de lei ou ato normativo poderá ser objeto de questão prejudicial, pela via do controle difuso.

Art. $5^{\circ}$ Pedido e causa de pedir - Nas ações coletivas, a causa de pedir e o pedido serão interpretados extensivamente, em conformidade com o bem jurídico a ser protegido. 
Parágrafo único. A requerimento da parte interessada, até a prolação da sentença, o juiz permitirá a alteração do pedido ou da causa de pedir, desde que seja realizada de boa-fé, não represente prejuízo injustificado para a parte contrária e o contraditório seja preservado, mediante possibilidade de nova manifestação de quem figure no pólo passivo da demanda, no prazo de 10 (dez) dias, com possibilidade de prova complementar, observado o parágrafo $3^{\circ}$ do artigo 10.

Art. $6^{\circ}$ Relacão entre demandas coletivas - Observado o disposto no artigo 22 deste Código, as demandas coletivas de qualquer espécie poderão ser reunidas, de ofício ou a requerimento das partes, ficando prevento o juízo perante o qual a demanda foi distribuída em primeiro lugar, quando houver:

I - conexão, pela identidade de pedido ou causa de pedir ou da defesa, conquanto diferentes os legitimados ativos, e para os fins da ação prevista no Capítulo III, os legitimados passivos;

II - conexão probatória, desde que não haja prejuízo à duração razoável do processo;

III - continência, pela identidade de partes e causa de pedir, observado o disposto no inciso anterior, sendo o pedido de uma das ações mais abrangente do que o das demais.

$\$ \mathbf{1}^{\mathbf{0}} \mathrm{Na}$ análise da identidade do pedido e da causa de pedir, será considerada a identidade do bem jurídico a ser protegido.

$\$ \mathbf{2}^{\mathbf{0}} \mathrm{Na}$ hipótese de conexidade entre ações coletivas referidas ao mesmo bem jurídico, o juiz prevento, até o início da instrução, deverá determinar a reunião de processos para julgamento conjunto e, iniciada a instrução, poderá determiná-la, desde que não haja prejuízo à duração razoável do processo;

$\$ 3^{\circ}$ Aplicam-se à litispendência as regras dos incisos I e III deste artigo, quanto à identidade de legitimados ativos ou passivos, e a regra de seu parágrafo $1^{\circ}$, quanto à identidade do pedido e da causa de pedir ou da defesa.

Art. $7^{\circ}$ Relação entre demanda coletiva e aç̃es individuais - A demanda coletiva não induz litispendência para as ações individuais em que sejam postulados direitos ou interesses próprios e específicos de seus autores, mas os efeitos da coisa julgada coletiva (art. 13 deste Código) não beneficiarão os autores das ações individuais, se não for requerida sua suspensão no prazo de 30 (trinta) dias, a contar da ciência efetiva da demanda coletiva nos autos da ação individual.

$\S \mathbf{1}^{\mathbf{0}}$ Cabe ao demandado informar o juízo da ação individual sobre a existência de demanda coletiva que verse sobre idêntico bem jurídico, sob pena de, não o fazendo, o autor individual beneficiar-se da coisa julgada coletiva mesmo no caso de a ação individual ser rejeitada.

\$ $\mathbf{2}^{\mathbf{0}}$ A suspensão do processo individual perdurará até o trânsito em julgado da sentença coletiva, facultado ao autor requerer a retomada do curso do processo individual, a qualquer tempo, independentemente da anuência do réu, hipótese em que não poderá mais beneficiar-se da sentença coletiva.

$\$ 3^{\circ}$ O Tribunal, de ofício, por iniciativa do juiz competente ou a requerimento da parte, após instaurar, em qualquer hipótese, o contraditório, poderá determinar a suspensão de processos individuais em que se postule a tutela de interesses ou direitos referidos a relação jurídica substancial de caráter incindível, pela sua própria natureza ou por força de lei, a cujo respeito as questões devam ser decididas de modo uniforme e globalmente, quando houver sido ajuizada demanda coletiva versando sobre o mesmo bem jurídico.

\$ $4^{\mathbf{0}} \mathrm{Na}$ hipótese do parágrafo anterior, a suspensão do processo perdurará até o trânsito em julgado da sentença coletiva, vedada ao autor a retomada do curso do processo individual antes desse momento.

Art. $8^{\circ}$ Comunicacão sobre processos repetitivos. O juiz, tendo conhecimento da existência de diversos processos individuais correndo contra o mesmo demandado, com identidade de fundamento jurídico, notificará o Ministério Público e, na medida do possível, outros legitimados, a fim de que proponham, querendo, demanda coletiva, ressalvada aos autores individuais a faculdade prevista no artigo anterior.

Parágrafo único. Caso o Ministério Público não promova a demanda coletiva, no prazo de 90 (noventa) dias, o juiz, se considerar relevante a tutela coletiva, fará remessa das peças dos processos individuais ao Conselho Superior do Ministério Público, que designará outro órgão do Ministério Público para ajuizar a demanda coletiva, ou insistirá, motivadamente, no não ajuizamento da ação, informando o juiz.

Art. $9^{0}$ Efeitos da citacão $-A$ citação válida para a demanda coletiva interrompe o prazo de prescrição das pretensões individuais e transindividuais direta ou indiretamente relacionadas com a controvérsia, retroagindo o efeito à data da propositura da ação.

Art. 10. Prioridade de processamento e utilizacão de meios eletrônicos - O juiz deverá dar prioridade ao processamento da demanda coletiva sobre as individuais, servindo-se preferencialmente dos meios eletrônicos para a prática de atos processuais do juízo e das partes, observados os critérios próprios que garantam sua autenticidade.

Art. 11. Provas - São admissíveis em juízo todos os meios de prova, desde que obtidos por meios lícitos, incluindo a prova estatística ou por amostragem. 
$\$ \mathbf{1}^{\circ}$ Sem prejuízo do disposto no artigo 333 do Código de Processo Civil, o ônus da prova incumbe à parte que detiver conhecimentos técnicos ou informações específicas sobre os fatos, ou maior facilidade em sua demonstração.

$\$ 2^{\circ} \mathrm{O}$ ônus da prova poderá ser invertido quando, a critério do juiz, for verossímil a alegação, segundo as regras ordinárias de experiência, ou quando a parte for hipossuficiente.

$\S 3^{\mathbf{0}}$ Durante a fase instrutória, surgindo modificação de fato ou de direito relevante para o julgamento da causa (parágrafo único do artigo $5^{\circ}$ deste Código), o juiz poderá rever, em decisão motivada, a distribuição do ônus da prova, concedendo à parte a quem for atribuída a incumbência prazo razoável para sua produção, observado o contraditório em relação à parte contrária (artigo 25, parágrafo $5^{\circ}$, inciso IV).

$\S 4^{\mathbf{0}}$. O juiz poderá determinar de ofício a produção de provas, observado o contraditório.

$\$ 5^{\circ}$. Para a realização de prova técnica, o juiz poderá solicitar a elaboração de laudos ou relatórios a órgãos, fundações ou universidades públicas especializados na matéria.

Art. 12. Motivação das decisões judiciárias. Todas as decisões deverão ser especificamente fundamentadas, especialmente quanto aos conceitos jurídicos indeterminados.

Parágrafo único. Na sentença de improcedência, o juiz deverá explicitar, no dispositivo, se rejeita a demanda por insuficiência de provas.

Art. 13. Coisa julgada - Nas ações coletivas de que trata este código, a sentença fará coisa julgada erga omnes, exceto se o pedido for julgado improcedente por insuficiência de provas, hipótese em que qualquer legitimado poderá intentar outra ação, com idêntico fundamento valendo-se de nova prova.

$\$ 1^{\mathbf{0}}$ Tratando-se de interesses ou direitos individuais homogêneos (art. $3^{\circ}$, III, deste Código), em caso de improcedência do pedido, os interessados poderão propor ação a título individual.

$\$ \mathbf{2}^{\circ}$ Os efeitos da coisa julgada nas ações em defesa de interesses ou direitos difusos ou coletivos (art. $4^{\circ}$, I e II, deste Código) não prejudicarão as ações de indenização por danos pessoalmente sofridos, propostas individualmente ou na forma prevista neste Código, mas, se procedente o pedido, beneficiarão as vítimas e seus sucessores, que poderão proceder à liquidação e à execução, nos termos dos arts. 34 e 35 .

$\$ 3^{\circ}$ Aplica-se o disposto no parágrafo anterior à sentença penal condenatória.

$\S 4^{\mathbf{0}}$ A competência territorial do órgão julgador não representará limitação para a coisa julgada erga omnes.

$\$ 5^{\circ}$ Mesmo na hipótese de sentença de improcedência, fundada nas provas produzidas, qualquer legitimado poderá intentar outra ação, com idêntico fundamento, no prazo de 2 (dois) anos contados do conhecimento geral da descoberta de prova nova, superveniente, que não poderia ser produzida no processo, desde que idônea para mudar seu resultado.

§ $\mathbf{6}^{\mathbf{0}}$ A faculdade prevista no parágrafo anterior, nas mesmas condições, fica assegurada ao demandado da ação coletiva julgada procedente.

Art. 14. Efeitos do recurso da sentença definitiva - O recurso interposto contra a sentença tem efeito meramente devolutivo, salvo quando a fundamentação for relevante e puder resultar à parte lesão grave e de difícil reparação, hipótese em que o juiz, ponderando os valores em jogo, poderá atribuir ao recurso efeito suspensivo.

Parágrafo único. As sentenças que julgam as demandas coletivas não se submetem ao reexame necessário.

Art. 15. Legitimação à liquidação e execucãa da sentença condenatória - Na hipótese de o autor da demanda coletiva julgada procedente não promover, em 120 (cento e vinte) dias, a liquidação ou execução da sentença, deverá fazê-lo o Ministério Público, quando se tratar de interesse público relevante, facultada igual iniciativa, em todos os casos, aos demais legitimados (art. 20 deste Código).

Art. 16. Execução definitiva e execução provisória - A execução é definitiva quando passada em julgado a sentença; e provisória, na pendência dos recursos cabíveis.

$\$ 1^{\circ}$ A execução provisória corre por conta e risco do exeqüente, que responde pelos prejuízos causados ao executado, em caso de reforma da sentença recorrida.

$\$ \mathbf{2}^{\mathbf{0}}$ A execução provisória permite a prática de atos que importem em alienação do domínio ou levantamento do depósito em dinheiro.

$\S 3^{\mathbf{0}}$ A pedido do executado, o tribunal pode suspender a execução provisória quando dela puder resultar lesão grave e de difícil reparação.

Art. 17. Custas e honorários - Nas demandas coletivas de que trata este código, a sentença condenará o demandado, se vencido, nas custas, emolumentos, honorários periciais e quaisquer outras despesas, bem como em honorários de advogados, calculados sobre a condenação. 
\$ $\mathbf{1}^{\mathbf{0}}$ Tratando-se de condenação a obrigação específica ou de condenação genérica, os honorários advocatícios serão fixados levando-se em consideração a vantagem para o grupo, categoria ou classe, a quantidade e qualidade do trabalho desenvolvido pelo advogado e a complexidade da causa.

\$ $2^{\circ}$ O Poder Público, quando demandado e vencido, incorrerá na condenação prevista neste artigo.

$\$ 3^{\mathbf{0}}$ Se o legitimado for pessoa física, entidade sindical ou de fiscalização do exercício das profissões, associação civil ou fundação de direito privado, o juiz, sem prejuízo da verba da sucumbência, poderá fixar gratificação financeira, a cargo do Fundo dos Direitos Difusos e Coletivos, quando sua atuação tiver sido relevante na condução e êxito da demanda coletiva, observados na fixação os critérios de razoabilidade e modicidade.

$\S 4^{\mathbf{0}}$ Os autores da demanda coletiva não adiantarão custas, emolumentos, honorários periciais e quaisquer outras despesas, nem serão condenados, salvo comprovada má-fé, em honorários de advogados, custas e despesas processuais.

\$ $5^{0}$ O litigante de má-fé e os responsáveis pelos respectivos atos serão solidariamente condenados ao pagamento das despesas processuais, em honorários advocatícios e em até o décuplo das custas, sem prejuízo da responsabilidade por perdas e danos.

Art. 18. Juízos especializados - Sempre que possível, as demandas coletivas de que trata este Código serão processadas e julgadas em juízos especializados.

Parágrafo único. Quando se tratar de liquidação e execução individuais dos danos sofridos em decorrência de violação a interesses ou direitos individuais homogêneos (artigo 34 deste Código), a competência para a tramitação dos processos será dos juízos residuais comuns.

\section{Capítulo II - Da ação coletiva ativa Seção I - Disposições gerais}

Art. 19. Cabimento da ação coletiva ativa. A ação coletiva ativa será exercida para a tutela dos interesses e direitos mencionados no artigo $4^{\circ}$ deste Código.

Art. 20. Legitimacão. São legitimados concorrentemente à ação coletiva ativa:

I - qualquer pessoa física, para a defesa dos interesses ou direitos difusos, desde que o juiz reconheça sua representatividade adequada, demonstrada por dados como:

a - a credibilidade, capacidade e experiência do legitimado;

b - seu histórico na proteção judicial e extrajudicial dos interesses ou direitos difusos e coletivos;

c - sua conduta em eventuais processos coletivos em que tenha atuado;

II - o membro do grupo, categoria ou classe, para a defesa dos interesses ou direitos coletivos, e individuais homogêneos, desde que o juiz reconheça sua representatividade adequada, nos termos do inciso I deste artigo;

III - o Ministério Público, para a defesa dos interesses ou direitos difusos e coletivos, bem como dos individuais homogêneos de interesse social;

IV - a Defensoria Pública, para a defesa dos interesses ou direitos difusos e coletivos, quando a coletividade ou os membros do grupo, categoria ou classe forem necessitados do ponto de vista organizacional, e dos individuais homogêneos, quando os membros do grupo, categoria ou classe forem, ao menos em parte, hiposuficientes;

$\mathrm{V}$ - as pessoas jurídicas de direito público interno, para a defesa dos interesses ou direitos difusos e, quando relacionados com suas funções, dos coletivos e individuais homogêneos;

VI - as entidades e órgãos da Administração Pública, direta ou indireta, bem como os órgãos do Poder Legislativo, ainda que sem personalidade jurídica, especificamente destinados à defesa dos interesses e direitos indicados neste Código;

VII - as entidades sindicais e de fiscalização do exercício das profissões, restritas as primeiras à defesa dos interesses e direitos ligados à categoria;

VIII - os partidos políticos com representação no Congresso Nacional, nas Assembléias Legislativas ou nas Câmaras Municipais, conforme o âmbito do objeto da demanda, para a defesa de direitos e interesses ligados a seus fins institucionais;

IX - as associações civis e as fundações de direito privado legalmente constituídas e em funcionamento há pelo menos um ano, que incluam entre seus fins institucionais a defesa dos interesses ou direitos indicados neste Código, dispensadas a autorização assemblear ou pessoal e a apresentação do rol nominal dos associados ou membros. 
$\S 1^{\circ} \mathrm{Na}$ defesa dos interesses ou direitos difusos, coletivos e individuais homogêneos, qualquer legitimado deverá demonstrar a existência do interesse social e, quando se tratar de direitos coletivos e individuais homogêneos, a coincidência entre os interesses do grupo, categoria ou classe e o objeto da demanda;

$\$ 2^{\mathbf{0}}$ No caso dos incisos I e II deste artigo, o juiz poderá voltar a analisar a existência do requisito da representatividade adequada em qualquer tempo e grau de jurisdição, aplicando, se for o caso, o disposto no parágrafo seguinte.

\$ $3^{\circ}$ Em caso de inexistência do requisito da representatividade adequada (incisos I e II deste artigo), o juiz notificará o Ministério Público e, na medida do possível, outros legitimados, a fim de que assumam, querendo, a titularidade da ação.

$\$ \mathbf{4}^{\mathbf{0}}$ Em relação às associações civis e às fundações de direito privado, o juiz poderá dispensar o requisito da pré-constituição, quando haja manifesto interesse social evidenciado pelas características do dano, pela relevância do bem jurídico a ser protegido ou pelo reconhecimento de representatividade adequada (inciso I deste artigo).

$\$ 5^{\circ}$ Os membros do Ministério Público poderão ajuizar a ação coletiva perante a Justiça federal ou estadual, independentemente da pertinência ao Ministério Público da União, do Distrito Federal ou dos Estados, e, quando se tratar da competência da Capital do Estado (artigo 22, inciso III) ou do Distrito Federal (artigo 22, inciso IV), independentemente de seu âmbito territorial de atuação.

\$ $6^{\mathbf{0}}$ Será admitido o litisconsórcio facultativo entre os legitimados, inclusive entre os Ministérios Públicos da União, do Distrito Federal e dos Estados.

$\S 7^{\circ}$ Em caso de relevante interesse social, cuja avaliação ficará a seu exclusivo critério, o Ministério Público, se não ajuizar a ação ou não intervier no processo como parte, atuará obrigatoriamente como fiscal da lei.

\$ $\mathbf{8}^{\mathbf{0}}$ Havendo vício de legitimação, desistência infundada ou abandono da ação, o juiz aplicará o disposto no parágrafo $3^{\circ}$ deste artigo.

$\$ 9^{\mathbf{0}}$ Em caso de inércia do Ministério Público, aplica-se o disposto no parágrafo único do artigo $8^{\circ}$ deste Código.

Art. 21. Do termo de ajustamento de conduta. Preservada a indisponibilidade do bem jurídico protegido, o Ministério Público e os órgãos públicos legitimados, agindo com critérios de equilíbrio e imparcialidade, poderão tomar dos interessados compromisso de ajustamento de conduta à lei, mediante fixação de modalidades e prazos para o cumprimento das obrigações assumidas e de multas por seu descumprimento.

$\$ \mathbf{1}^{\mathbf{o}} \cdot$ Em caso de necessidade de outras diligências, os órgãos públicos legitimados poderão firmar compromisso preliminar de ajustamento de conduta.

§ $2^{\mathbf{0}}$ Quando a cominação for pecuniária, seu valor deverá ser suficiente e necessário para coibir o descumprimento da medida pactuada e poderá ser executada imediatamente, sem prejuízo da execução específica.

$\$ \mathbf{3}^{\mathbf{o}}$. O termo de ajustamento de conduta terá natureza jurídica de transação, com eficácia de título executivo extrajudicial, sem prejuízo da possibilidade de homologação judicial do compromisso, hipótese em que sua eficácia será de título executivo judicial.

Art. 22. Competência territorial - É absolutamente competente para a causa o foro:

I - do lugar onde ocorreu ou deva ocorrer o dano, quando de âmbito local;

II - de qualquer das comarcas ou sub-seções judiciárias, quando o dano de âmbito regional compreender até 3 (três) delas, aplicando-se no caso as regras de prevenção;

III - da Capital do Estado, para os danos de âmbito regional, compreendendo 4 (quatro) ou mais comarcas ou sub-seções judiciárias;

IV - de uma das Capitais do Estado, quando os danos de âmbito interestadual compreenderem até 3 (três) Estados, aplicando-se no caso as regras de prevenção;

IV- do Distrito Federal, para os danos de âmbito interestadual que compreendam mais de 3 (três) Estados, ou de âmbito nacional.

$\$ \mathbf{1}^{\mathbf{0}}$ A amplitude do dano será aferida conforme indicada na petição inicial da demanda.

$\$ 2^{\mathbf{0}}$ Ajuizada a demanda perante juiz territorialmente incompetente, este remeterá incontinenti os autos ao juízo do foro competente, sendo vedada ao primeiro juiz a apreciação de pedido de antecipação de tutela.

$\S 3^{\text {o }}$ No caso de danos de âmbito nacional, interestadual e regional, o juiz competente poderá delegar a realização da audiência preliminar e da instrução ao juiz que ficar mais próximo dos fatos.

\$ $4^{\text {o }}$ Compete ao juiz estadual, nas comarcas que não sejam sede da Justiça federal, processar e julgar a ação coletiva nas causas de competência da Justiça federal. 
Art. 23. Inquérito civil. O Ministério Público poderá instaurar, sob sua presidência, inquérito civil, nos termos do disposto em sua Lei Orgânica, ou requisitar, de qualquer organismo público ou particular, certidões, informações, exames ou perícias, no prazo que assinalar, o qual não poderá ser inferior a 10 (dez) dias.

$\$ \mathbf{1}^{\mathbf{0}}$ Aplica-se às atribuições do Ministério Público, em relação ao inquérito civil, o disposto no parágrafo $5^{\circ}$ do artigo 20 deste Código.

$\$ 2^{\circ}$ Nos casos em que a lei impuser sigilo, incumbe ao Ministério Público, ao inquirido e a seu advogado a manutenção do segredo.

$\$ 3^{\circ}$ A eficácia probante das peças informativas do inquérito civil dependerá da observância do contraditório, ainda que diferido para momento posterior ao da sua produção;

$\$ 4^{0}$ Se o órgão do Ministério Público, esgotadas todas as diligências, se convencer da inexistência de fundamento para a propositura de ação coletiva, promoverá o arquivamento dos autos do inquérito civil ou das peças informativas, fazendo-o fundamentadamente.

$\$ 5^{\circ}$ Os demais legitimados (art. 20 deste Código) poderão recorrer da decisão de arquivamento ao Conselho Superior do Ministério Público, conforme dispuser o seu regimento.

§ $6^{\circ} \mathrm{O}$ órgão do Ministério Público que promover o arquivamento do inquérito civil ou das peças informativas encaminhará, no prazo de 3 (três) dias, sob pena de falta grave, os respectivos autos ao Conselho Superior do Ministério Público, para homologação e para as medidas necessárias à uniformização da atuação ministerial.

$\$ 7^{\circ}$ Deixando o Conselho de homologar a promoção do arquivamento, designará, desde logo, outro membro do Ministério Público para o ajuizamento da ação.

$\$ \mathbf{8}^{\circ}$ Constituem crime, punido com pena de reclusão de 1 (um) a 3 (três) anos, mais multa, a recusa, o retardamento ou a omissão de dados técnicos ou informações, quando requisitados pelo Ministério Público.

Art. 24. Da instrucão da inicial e do valor da causa - Para instruir a inicial, o legitimado poderá requerer às autoridades competentes as certidões e informações que julgar necessárias.

$\$ \mathbf{1}^{\mathbf{0}}$ As certidões e informações deverão ser fornecidas dentro de 15 (quinze) dias da entrega, sob recibo, dos respectivos requerimentos, e só poderão ser utilizados para a instrução da ação coletiva.

$\$ \mathbf{2}^{\mathbf{0}}$ Somente nos casos em que a defesa da intimidade ou o interesse social, devidamente justificados, exigirem o sigilo, poderá ser negada certidão ou informação.

\$ $3^{\mathbf{0}}$ Ocorrendo a hipótese do parágrafo anterior, a ação poderá ser proposta desacompanhada das certidões ou informações negadas, cabendo ao juiz, após apreciar os motivos do indeferimento, requisitá-las; feita a requisição, o processo correrá em segredo de justiça.

$\S 4^{\mathbf{0}} \mathrm{Na}$ hipótese de ser incomensurável ou inestimável o valor dos danos coletivos, fica dispensada a indicação do valor da causa na petição inicial, cabendo ao juiz fixá-lo em sentença.

Art. 25 - Audiência preliminar - Encerrada a fase postulatória, o juiz designará audiência preliminar, à qual comparecerão as partes ou seus procuradores, habilitados a transigir.

$\$ \mathbf{1}^{\mathbf{0}} \mathrm{O}$ juiz ouvirá as partes sobre os motivos e fundamentos da demanda e tentará a conciliação, sem prejuízo de sugerir outras formas adequadas de solução do conflito, como a mediação, a arbitragem e a avaliação neutra de terceiro.

$\$ 2^{\mathbf{0}}$ A avaliação neutra de terceiro, de confiança das partes, obtida no prazo fixado pelo juiz, é sigilosa, inclusive para este, e não vinculante para as partes, sendo sua finalidade exclusiva a de orientá-las na tentativa de composição amigável do conflito.

$\$ 3^{\mathbf{o}}$ Preservada a indisponibilidade do bem jurídico coletivo, as partes poderão transigir sobre o modo de cumprimento da obrigação.

$\$ 4^{\circ}$ Obtida a transação, será homologada por sentença, que constituirá título executivo judicial.

$\$ 5^{\circ}$ Não obtida a conciliação, sendo ela parcial, ou quando, por qualquer motivo, não for adotado outro meio de solução do conflito, o juiz, fundamentadamente:

I - decidirá se a ação tem condições de prosseguir na forma coletiva, certificando-a como tal;

II - poderá separar os pedidos em ações coletivas distintas, voltadas à tutela, respectivamente, dos interesses ou direitos difusos e coletivos, de um lado, e dos individuais homogêneos, do outro, desde que a separação represente economia processual ou facilite a condução do processo;

III - decidirá a respeito do litisconsórcio e da intervenção de terceiros, esta admissível até o momento do saneamento do processo, vedada a denunciação da lide na hipótese do artigo 13, parágrafo único, da Lei n. 8.078, de 11 de setembro de 1990 - Código de Defesa do Consumidor. 
IV - fixará os pontos controvertidos, decidirá as questões processuais pendentes e determinará as provas a serem produzidas, designando audiência de instrução e julgamento, se for o caso;

$\mathrm{V}$ - Na hipótese do inciso anterior, esclarecerá as partes sobre a distribuição do ônus da prova, de acordo com o disposto no parágrafo $1^{\circ}$ do artigo 11 deste Código, e sobre a possibilidade de ser determinada, no momento do julgamento, sua inversão, nos termos do parágrafo $2^{\circ}$ do mesmo artigo;

VI - Se não houver necessidade de audiência de instrução e julgamento, de acordo com a natureza do pedido e as provas documentais juntadas pelas partes ou requisitadas pelo juiz, sobre as quais tenha incidido o contraditório, simultâneo ou sucessivo, julgará antecipadamente a lide.

Art. 26. Ação reparatória - $\mathrm{Na}$ ação reparatória dos danos provocados ao bem indivisivelmente considerado, sempre que possível e independentemente de pedido do autor, a condenação consistirá na prestação de obrigações específicas, destinadas à compensação do dano sofrido pelo bem jurídico afetado, nos termos do artigo 461 e parágrafos do Código de Processo Civil.

$\S 1^{0}$ Dependendo da especificidade do bem jurídico afetado, da extensão territorial abrangida e de outras circunstâncias consideradas relevantes, o juiz poderá especificar, em decisão fundamentada, as providências a serem tomadas para a reconstituição dos bens lesados, podendo indicar a realização de atividades tendentes a minimizar a lesão ou a evitar que se repita, dentre outras que beneficiem o bem jurídico prejudicado;

$\$ \mathbf{2}^{\mathbf{0}}$ Somente quando impossível a condenação no cumprimento de obrigações específicas, o juiz condenará o réu, em decisão fundamentada, ao pagamento de indenização, independentemente de pedido do autor, a qual reverterá ao Fundo de Direitos Difusos e Coletivos, de natureza federal ou estadual, de acordo com a Justiça competente (art. 27 deste Código).

Art. 27. Do Fundo dos Direitos Difusos e Coletivos. O Fundo será administrado por um Conselho Gestor federal ou por Conselhos Gestores estaduais, dos quais participarão necessariamente, em composição paritária, membros do Ministério Público e representantes da comunidade, sendo seus recursos destinados à realização de atividades tendentes a minimizar as lesões ou a evitar que se repitam, dentre outras que beneficiem os bens jurídicos prejudicados, bem como a antecipar os custos das perícias necessárias à defesa dos direitos ou interesses difusos, coletivos e individuais homogêneos e a custear o prêmio previsto no parágrafo $3^{\circ}$ do artigo 17.

$\$ \mathbf{1}^{\mathbf{0}}$ Além da indenização oriunda da sentença condenatória, prevista no parágrafo $2^{\mathbf{0}}$ do artigo 26 , e da execução pelos danos globalmente causados, de que trata o parágrafo $3^{\circ}$ do artigo 36, ambos deste Código, constitui receita do Fundo, dentre outras, o produto da arrecadação de multas, inclusive as decorrentes do descumprimento de compromissos de ajustamento de conduta.

$\$ 2^{\circ} \mathrm{O}$ representante legal do Fundo, considerado funcionário público para efeitos legais, responderá por sua atuação nas esferas administrativa, penal e civil.

\$ $3^{\mathbf{0}}$ O Fundo será notificado da propositura de toda ação coletiva e sobre as decisões mais importantes do processo, podendo nele intervir em qualquer tempo e grau de jurisdição na função de "amicus curiae".

\$ 4 O Fundo manterá e divulgará registros que especifiquem a origem e a destinação dos recursos e indicará a variedade dos bens jurídicos a serem tutelados e seu âmbito regional;

\$ $5^{\circ}$ Semestralmente, o Fundo dará publicidade às suas demonstrações financeiras e atividades desenvolvidas.

\section{Seção II - Da ação coletiva para a defesa de interesses ou direitos individuais homogêneos}

Art. 28. Da ação coletiva para a defesa de interesses ou direitos individuais homogêneos - A ação coletiva para a defesa de interesses ou direitos individuais homogêneos será exercida para a tutela do conjunto de direitos ou interesses individuais, decorrentes de origem comum, de que sejam titulares os membros de um grupo, categoria ou classe.

$\$ \mathbf{1}^{\mathbf{0}}$ Para a tutela dos interesses ou direitos individuais homogêneos, além dos requisitos indicados no artigo 19 deste Código, é necessária a aferição da predominância das questões comuns sobre as individuais e da utilidade da tutela coletiva no caso concreto.

\$ $\mathbf{2}^{\mathbf{0}}$ A determinação dos interessados poderá ocorrer no momento da liquidação ou execução do julgado, não havendo necessidade de a petição inicial vir acompanhada da respectiva relação nominal.

Art. 29. Acão de responsabilidade civil - Os legitimados poderão propor, em nome próprio e no interesse das vítimas ou seus sucessores, dentre outras (artigo 2. ${ }^{\circ}$ deste Código), ação coletiva de responsabilidade pelos danos individualmente sofridos, de acordo com o disposto nos artigos seguintes.

Art. 30. Citação e notificacões - Estando em termos a petição inicial, o juiz ordenará a citação do réu e a publicação de edital, de preferência resumido, no órgão oficial, a fim de que os interessados possam intervir 
no processo como assistentes, observado o disposto no parágrafos $5^{\circ}$ e $6^{\circ}$ deste artigo.

$\$ 1^{\circ}$ Sem prejuízo da publicação do edital, o juiz determinará sejam os órgãos e entidades de defesa dos interesses ou direitos indicados neste Código comunicados da existência da demanda coletiva e de seu trânsito em julgado, a serem também comunicados ao Cadastro Nacional de Processos Coletivos

\$ $2^{\circ}$ Concedida a tutela antecipada e sendo identificáveis os beneficiários, o juiz determinará ao demandado que informe os interessados sobre a opção de exercerem, ou não, o direito à fruição da medida.

\$ $3^{\circ}$ Descumprida a determinação judicial de que trata o parágrafo anterior, o demandado responderá, no mesmo processo, pelos prejuízos causados aos beneficiários.

\$ $4^{\mathbf{0}}$ Quando for possível a execução do julgado, ainda que provisória, o juiz determinará a publicação de edital no órgão oficial, às expensas do demandado, impondo-lhe, também, o dever de divulgar, pelos meios de comunicação social, nova informação, compatível com a extensão ou gravidade do dano, observado o critério da modicidade do custo. Sem prejuízo das referidas providências, o juízo providenciará a comunicação aos órgãos e entidades de defesa dos interesses ou direitos indicados neste Código, bem como ao Cadastro Nacional de Processos Coletivos.

\$ $5^{\circ}$ A apreciação do pedido de assistência far-se-á em autos apartados, sem suspensão do feito, recebendo o interveniente o processo no estado em que se encontre.

$\S 6^{\circ}$ Os intervenientes não poderão discutir suas pretensões individuais na fase de conhecimento do processo coletivo.

Art. 31. Efeitos da transação - As partes poderão transacionar, ressalvada aos membros do grupo, categoria ou classe a faculdade de não aderir à transação, propondo ação a título individual.

Art. 32 - Sentença condenatória - Sempre que possível, o juiz fixará na sentença o valor da indenização individual devida a cada membro do grupo, categoria ou classe.

$\$ \mathbf{1}^{\mathbf{0}}$ Quando o valor dos danos individuais sofridos pelos membros do grupo, categoria ou classe for uniforme, prevalentemente uniforme ou puder ser reduzido a uma fórmula matemática, a sentença coletiva indicará o valor ou a fórmula de cálculo da indenização individual.

$\$ 2^{\circ} \mathrm{O}$ membro do grupo, categoria ou classe que divergir quanto ao valor da indenização individual ou à fórmula para seu cálculo, estabelecidos na sentença coletiva, poderá propor ação individual de liquidação.

$\S 3^{0}$ Não sendo possível a prolação de sentença condenatória líquida, a condenação poderá ser genérica, fixando a responsabilidade do demandado pelos danos causados e o dever de indenizar.

Art. 33. Competência para a liquidação e execucão - É competente para a liquidação e execução o juízo:

I - da fase condenatória da ação ou da sede do legitimado à fase de conhecimento, quando coletiva a liquidação ou execução.

II- da fase condenatória, ou do domicílio da vítima ou sucessor, no caso de liquidação ou execução individual.

$\$ \mathbf{1}^{\mathbf{0}} \mathrm{O}$ exeqüente poderá optar pelo juízo do local onde se encontrem bens sujeitos à expropriação.

$\$ 2^{\circ}$ Quando a competência para a liquidação e execução não for do juízo da fase de conhecimento, o executado será citado, seguindo a execução o procedimento do art. 475-A e seguintes do Código de Processo Civil.

Art. 34. Liquidação e execução individuais. A liquidação e execução serão promovidas individualmente pelo beneficiário ou seus sucessores, que poderão ser representados, mediante instrumento de mandato, por associações, entidades sindicais ou de fiscalização do exercício das profissões e defensorias públicas, ainda que não tenham sido autoras na fase de conhecimento, observados os requisitos do artigo 20 deste Código.

$\S \mathbf{1}^{\mathbf{o}} \mathrm{Na}$ liquidação da sentença caberá ao liquidante provar, tão só, o dano pessoal, o nexo de causalidade e o montante da indenização.

\$ $\mathbf{2}^{\mathbf{0}}$ A liquidação da sentença poderá ser dispensada quando a apuração do dano pessoal, do nexo de causalidade e do montante da indenização depender exclusivamente de prova documental, hipótese em que o pedido de execução por quantia certa será acompanhado dos documentos comprobatórios e da memória do cálculo.

\$ $3^{\text {o }}$ Os valores destinados ao pagamento das indenizações individuais serão depositados em instituição bancária oficial, abrindo-se conta remunerada e individualizada para cada beneficiário, regendo-se os respectivos saques, sem expedição de alvará, pelas normas aplicáveis aos depósitos bancários.

$\$ 4^{\mathbf{0}} \mathrm{Na}$ hipótese de o exercício da ação coletiva ter sido contratualmente vinculado ao pagamento de remuneração ajustada por serviços prestados, o montante desta será deduzido dos valores destinados ao pagamento previsto no parágrafo anterior, ficando à disposição da entidade legitimada. 
\$ 5 $5^{\circ}$ A carta de sentença para a execução provisória poderá ser extraída em nome do credor, ainda que este não tenha integrado a lide na fase de conhecimento do processo.

Art. 35. Liquidacão e execucão coletivas - Se possível, a liquidação e a execução serão coletivas, sendo promovidas por qualquer dos legitimados do artigo 20 deste Código.

Art. 36. Liquidação e execução pelos danos globalmente causados - Decorrido o prazo de um ano sem habilitação de interessados em número compatível com a gravidade do dano, poderão os legitimados do artigo 20 deste Código promover a liquidação e execução coletiva da indenização devida pelos danos causados.

$\$ \mathbf{1}^{\mathbf{0}} \mathrm{Na}$ fluência do prazo previsto no caput deste artigo a prescrição não correrá.

\$ $\mathbf{2}^{\mathbf{0}} \mathrm{O}$ valor da indenização será fixado de acordo com o dano globalmente causado, que poderá ser demonstrado por meio de prova pré-constituída ou, não sendo possível, mediante liquidação.

$\$ 3^{0} \mathrm{O}$ produto da indenização reverterá ao Fundo (art. 27 deste Código), que o utilizará para finalidades conexas à proteção do grupo, categoria ou classe beneficiados pela sentença.

\$ $4^{\mathbf{0}}$ Enquanto não se consumar a prescrição da pretensão individual, fica assegurado o direito de exigir o pagamento pelo Fundo, limitado o total das condenações ao valor que lhe foi recolhido.

Art. 37. Concurso de créditos - Em caso de concurso de créditos decorrentes de condenação de que trata o artigo 26 deste Código e de indenizações pelos prejuízos individuais resultantes do mesmo evento danoso, estas terão preferência no pagamento.

Parágrafo único. Para efeito do disposto neste artigo, a destinação da importância a ser recolhida ao Fundo ficará sustada enquanto pendentes de decisão de recurso ordinário as ações de indenização pelos danos individuais, salvo na hipótese de o patrimônio do devedor ser manifestamente suficiente para responder pela integralidade das dívidas.

\section{Capítulo III - Da ação coletiva passiva originária}

Art. 38. Acões contra o grupo, categoria ou classe - Qualquer espécie de ação pode ser proposta contra uma coletividade organizada, mesmo sem personalidade jurídica, desde que apresente representatividade adequada (artigo 20, I, "a", "b" e "c"), se trate de tutela de interesses ou direitos difusos e coletivos (artigo $4^{\circ}$, incisos I e II) e a tutela se revista de interesse social.

Parágrafo único. O Ministério Público e os órgãos públicos legitimados à ação coletiva ativa (art. 20, incisos III, IV, V e VI e VII deste Código) não poderão ser considerados representantes adequados da coletividade, ressalvadas as entidades sindicais.

Art. 39. Coisa julgada passiva -A coisa julgada atuará erga omnes, vinculando os membros do grupo, categoria ou classe e aplicando-se ao caso as disposições do artigo 12 deste Código, no que dizem respeito aos interesses ou direitos transindividuais.

Art. 40. Aplicacão complementar às acões coletivas passivas - Aplica-se complementarmente às ações coletivas passivas o disposto no Capítulo I deste Código, no que não for incompatível.

Parágrafo único. As disposições relativas a custas e honorários, previstas no artigo 16 e seus parágrafos, serão invertidas, para beneficiar o grupo, categoria ou classe que figurar no pólo passivo da demanda.

\section{Capítulo IV - Do mandado de segurança coletivo}

Art. 41. Cabimento do mandado de segurança coletivo - Conceder-se-á mandado de segurança coletivo, nos termos dos incisos LXIX e LXX do artigo $5^{\circ}$ da Constituição federal, para proteger direito líquido e certo relativo a interesses ou direitos difusos, coletivos ou individuais homogêneos (art. $4^{\circ}$ deste Código).

Art. 42. Legitimacão ativa - O mandado de segurança coletivo pode ser impetrado por:

I - Ministério Público;

II - Defensoria Pública;

III - partido político com representação no Congresso Nacional;

IV - entidade sindical, entidade de classe ou associação legalmente constituída e em funcionamento há pelo menos um ano, em defesa dos interesses de seus membros ou associados, dispensada a autorização assemblear.

Parágrafo único - O Ministério Público, se não impetrar o mandado de segurança coletivo, atuará como fiscal da lei, em caso de interesse público ou relevante interesse social. 
Art. 43. Disposicões aplicáveis - Aplicam-se ao mandado de segurança coletivo as disposições do Capítulo I deste Código, inclusive no tocante às custas e honorários (art. 17 e seus parágrafos) e as da Lei n. ${ }^{\circ}$ 1.533/51, no que não for incompatível.

\section{Capítulo V - Das ações populares \\ Seção I - Da ação popular constitucional}

Art. 44 - Disposições aplicáveis - Aplicam-se à ação popular constitucional as disposições do Capítulo I deste Código e as da Lei n. 4.717, de 29 de junho de 1965.

\section{Seção II - Ação de improbidade administrativa}

Art. 45. Disposiç̃os aplicáveis - A ação de improbidade administrativa rege-se pelas disposições do Capítulo I deste Código, com exceção do disposto no artigo $5^{\circ}$ e seu parágrafo único, devendo o pedido e a causa de pedir ser interpretados restritivamente, e pelas disposições da Lei n. 8.429, de 2 de junho de 1992,

\section{Capítulo VI - Disposições finais}

Art. 46. Do Cadastro Nacional de Processos Coletivos - O Conselho Nacional de Justiça organizará e manterá o Cadastro Nacional de Processos Coletivos, com a finalidade de permitir que todos os órgãos do Poder Judiciário e todos os interessados tenham acesso ao conhecimento da existência de ações coletivas, facilitando a sua publicidade.

$\$ \mathbf{1}^{\circ}$ Os órgãos judiciários aos quais forem distribuídos processos coletivos remeterão, no prazo de 10 (dez) dias, cópia da petição inicial ao Cadastro Nacional de Processos Coletivos.

§ $2^{\circ}$ O Conselho Nacional de Justiça, no prazo de 90 (noventa) dias, editará regulamento dispondo sobre o funcionamento do Cadastro Nacional de Processos Coletivos, incluindo a forma de comunicação pelos juízos quanto à existência de processos coletivos e aos atos processuais mais relevantes, como a concessão de antecipação de tutela, a sentença e o trânsito em julgado, a interposição de recursos e seu andamento, a execução provisória ou definitiva; disciplinará, ainda, os meios adequados a viabilizar o acesso aos dados e seu acompanhamento por qualquer interessado.

Art. 47. Instalacão de órgãos especializados - A União, no prazo de 180 (cento e oitenta) dias, e os Estados criarão e instalarão órgãos especializados, em primeira e segunda instância, para o processamento e julgamento de ações coletivas.

Art. 48. Princípios de interpretação - Este Código será interpretado de forma aberta e flexível, compatível com a tutela coletiva dos direitos e interesses de que trata.

Art. 49. Aplicação subsidiária do Código de Processo Civil - Aplicam-se subsidiariamente às ações coletivas, no que não forem incompatíveis, as disposições do Código de Processo Civil, independentemente da Justiça competente para o processamento e julgamento.

Parágrafo único - Os recursos cabíveis e seu processamento seguirão o disposto no Código de Processo Civil e legislação correlata, no que não for incompatível.

Art. 50. Nova redação - Dê-se nova redação aos artigos de leis abaixo indicados:

a - Dê-se aos $\S \S 4^{\circ}$ e $5^{\circ}$ do art. 273 da Lei no 5.869, de 11 de janeiro de 1973 (Código de Processo Civil), a seguinte redação:

"Art. 273

$\S 4^{\circ}$. A tutela antecipada poderá ser revogada ou modificada, fundamentadamente, enquanto não se produza a preclusão da decisão que a concedeu ( $\$ 1^{\circ}$ do art. 273-B e art. 273-C).

$\S 5^{\circ}$. Na hipótese do inciso I deste artigo, o juiz só concederá a tutela antecipada sem ouvir a parte contrária em caso de extrema urgência ou quando verificar que o réu, citado, poderá torná-la ineficaz”.

b - A Lei $\mathrm{n}^{\circ}$ 5.869, de 11 de janeiro de 1973 (Código de Processo Civil), passa a vigorar acrescida dos seguintes arts.: 273-A, 273-B, 273-C, 273-D:

“Art. 273-A. A antecipação de tutela poderá ser requerida em procedimento antecedente ou na pendência do processo".

“Art. 273-B. Aplicam-se ao procedimento previsto no art. 273-A, no que couber, as disposições do Livro III, Título único, Capítulo I deste Código.

$\S 1^{\circ}$. Concedida a tutela antecipada em procedimento antecedente, é facultado, até 30 (trinta) dias contados da preclusão da decisão concessiva:

a) ao réu, propor demanda que vise à sentença de mérito;

b) ao autor, em caso de antecipação parcial, propor demanda que vise à satisfação integral da pretensão. 
$\S 2^{\circ}$. Não intentada a ação, a medida antecipatória adquirirá força de coisa julgada nos limites da decisão proferida".

"Art. 273-C. Concedida a tutela antecipada no curso do processo, é facultado à parte interessada, até 30 (trinta) dias contados da preclusão da decisão concessiva, requerer seu prosseguimento, objetivando o julgamento de mérito.

Parágrafo único. Não pleiteado o prosseguimento do processo, a medida antecipatória adquirirá força de coisa julgada nos limites da decisão proferida".

“Art. 273-D Proposta a demanda ( $\S 1^{\circ}$ do art. 273-B) ou retomado o curso do processo (art. 273-C), sua eventual extinção, sem julgamento do mérito, não ocasionará a ineficácia da medida antecipatória, ressalvada a carência da ação, se incompatíveis as decisões."

c - O artigo 10 da Lei n. 1.533, de 31 de dezembro de 1951, passa a ter a seguinte redação:

Artigo 10: "Findo o prazo a que se refere o item I do art. $7^{\circ}$ e ouvido, dentro de 5 (cinco) dias, o representante da pessoa jurídica de direito público, responsável pela conduta impugnada, os autos serão conclusos ao juiz, independentemente de solicitação da parte, para a decisão, a qual deverá ser proferida em 5 (cinco) dias, tenham sido ou não prestadas as informações pela autoridade coatora".

d - O artigo $7^{\circ}$, inciso I, alínea "a”, da Lei n. 4717, de 29 de junho de 1965, passa a ter a seguinte redação:

Art. $7^{\circ}-"$.

I -

a - além da citação dos réus, a intimação do representante do Ministério Público, que poderá intervir no processo como litisconsorte ou fiscal da lei, devendo fazê-lo obrigatoriamente quando se tratar, a seu exclusivo critério, de interesse público relevante, vedada, em qualquer caso, a defesa dos atos impugnados ou de seus autores."

e- Acrescente-se ao artigo 18 da Lei n. 4717, de 29 de junho de 1965 um parágrafo único, com a seguinte redação:

Art. 18 - “.

Parágrafo único - Mesmo na hipótese de improcedência fundada nas provas produzidas, qualquer legitimado poderá intentar outra ação, com idêntico fundamento, no prazo de 2 (dois) anos contados do conhecimento geral da descoberta de prova nova, superveniente, que não poderia ser produzida no processo, desde que idônea, por si só, para mudar seu resultado."

f - Acrescentem-se ao artigo 17 da Lei n. 8.429, de 2 de junho de 1992, dois parágrafos, numerados como $1^{\circ} \mathrm{e}$ $2^{\circ}$, renumerando-se os atuais parágrafos $1^{\circ}, 2^{\circ}, 3^{\circ}, 4^{\circ}, 5^{\circ}, 6^{\circ}, 7^{\circ}, 8^{\circ}, 9^{\circ}, 10,11$ e $12 \operatorname{como~} 3^{\circ}, 4^{\circ}, 5^{\circ}, 6^{\circ}, 7^{\circ}$, $8^{\circ}, 9^{\circ}, 10,11,12,13$ e 14 .

Art.17 - “.

$\S 1^{\circ}$ - Nas hipóteses em que, pela natureza e circunstâncias de fato ou pela condição dos responsáveis, o interesse social não apontar para a necessidade de pronta e imediata intervenção do Ministério Público, este, a seu exclusivo critério, poderá, inicialmente, provocar a iniciativa do Poder Público co-legitimado, zelando pela observância do prazo prescricional e, sendo proposta a ação, intervir nos autos respectivos como fiscal da lei, nada obstando que, em havendo omissão, venha a atuar posteriormente, inclusive contra a omissão, se for o caso.

$\S 2^{\circ}$ - No caso de a ação principal ter sido proposta pelo Ministério Público, a pessoa jurídica interessada integrará a lide na qualidade de litisconsorte, cabendo-lhe apresentar ou indicar os meios de prova de que disponha.

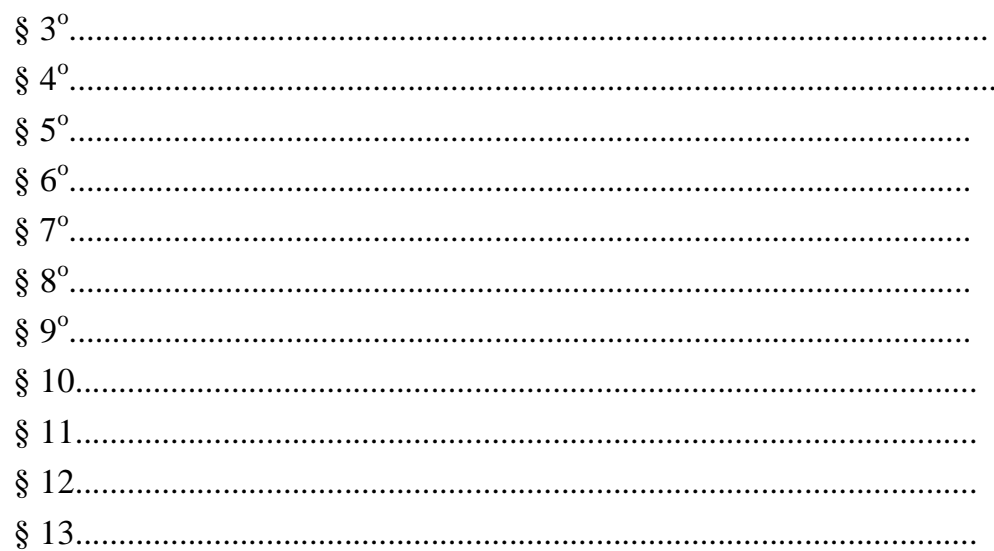


$\S 14$.

g - O artigo 80 da Lei n. 10.741 , de $1^{\circ}$ de outubro de 2003, passa a ter a seguinte redação:

Artigo 80: "As ações individuais movidas pelo idoso serão propostas no foro de seu domicílio, cujo juízo terá competência absoluta para processar e julgar a causa".

Art. 51. Revogacão - Revogam-se a Lei $n^{\circ} 7.347$, de 24 de julho de 1985; os artigos 81 a 104 da Lei n. $^{\circ}$ 8.078, de 11 de setembro de 1990; o parágrafo $3^{\circ}$ do artigo $5^{\circ}$ da Lei n. 4.717, de 29 de junho de 1965; os artigos $3^{\circ}, 4^{\circ}, 5^{\circ}, 6^{\circ}$ e $7^{\circ}$ da Lei n. 7.853 , de 24 de outubro de 1989 ; o artigo $3^{\circ}$ da Lei n. 7.913, de 7 de dezembro de 1989; os artigos 210, 211, 212, 213, 215, 217, 218, 219, 222, 223 e 224 da Lei n. 8.069, de 13 de junho de 1990; o artigo $2^{\circ}$ da Lei n. 9.494, de 10 de setembro de 1997; e os artigos 81, 82, 83, 85, 91, 92 e 93 da Lei n. 10.741, de $1^{\circ}$ de outubro de 2003.

Art. 52. Vigência - Este Código entrará em vigor dentro de cento e oitenta dias a contar de sua publicação.

Janeiro de 2007. 


\section{ANEXO D \\ ANTEPROJETO DE LEI DA AÇÃO CIVIL PÚBLICA (SISTEMA ÚNICO COLETIVO)}

LEI No ........, DE .............

Disciplina a ação civil pública e as demais ações coletivas para a tutela de interesses ou direitos difusos, coletivos e individuais homogêneos dá outras providências.

O PRESIDENTE DA REPÚBLICA, faço saber que o Congresso Nacional decreta e eu sanciono a seguinte Lei:

\section{CAPÍTULO I - DISPOSIÇÕES GERAIS}

Art. $1^{\circ}$. Regem-se pelas disposições desta Lei, as ações civis públicas e as demais ações coletivas destinadas à proteção:

I - do meio ambiente, saúde, educação, previdência e assistência social, trabalho, desporto, segurança pública, transportes coletivos, assistência jurídica integral e serviços públicos;

II - do consumidor, idoso, infância e juventude, portadores de necessidades especiais;

III - da ordem social, econômica, urbanística, financeira e tributária, da economia popular, da livre concorrência, do patrimônio público, incluído o erário;

IV - dos bens e direitos de valor artístico, cultural, estético, histórico, turístico e paisagístico; e

$\mathrm{V}$-outros direitos e interesses difusos, coletivos ou individuais homogêneos.

Art. $2^{\circ}$. A tutela coletiva abrange os interesses ou direitos:

I - difusos, assim entendidos os transindividuais, de natureza indivisível, de que sejam titulares pessoas indeterminadas, ligadas por circunstâncias de fato;

II - coletivos em sentido estrito, assim entendidos os transindividuais, de natureza indivisível, de que seja titular grupo, categoria ou classe de pessoas ligadas entre si ou com a parte contrária por uma relação jurídica base;

III - individuais homogêneos, assim entendidos aqueles decorrentes de origem comum, de fato ou de direito, que recomendem tutela conjunta a ser aferida por critérios como facilitação do acesso à Justiça, economia processual, preservação da isonomia processual, segurança jurídica e dificuldade na formação do litisconsórcio.

$\S 1^{\circ}$. A tutela dos interesses ou direitos difusos, coletivos e individuais homogêneos presume-se de relevância social, política, economica ou jurídica.

$\S 2^{\circ}$. A análise da constitucionalidade ou inconstitucionalidade de lei ou ato normativo poderá ser argüida incidentalmente, como questão prejudicial, pela via do controle difuso.

Art. $3^{\circ}$. Para a defesa dos direitos e interesses protegidos por esta lei são admissíveis todas as espécies de ações e provimentos capazes de propiciar sua adequada e efetiva tutela.

Art. $4^{\circ}$. A ação coletiva seguirá o rito ordinário estabelecido no código de processo civil, obedecidas as modificações previstas nesta lei. Quando a tramitação processual prevista não se adequar às especificidades da causa ou das partes, o juiz poderá determinar a prática de atos que melhor se ajustem ao fim e às necessidades do processo coletivo, procedendo às necessárias adaptações.

\section{CAPÍTULO II - DOS PRINCÍPIOS DO PROCESSO CIVIL COLETIVO}

Art. $5^{\circ}$. O processo civil coletivo rege-se pelos seguintes princípios:

I - amplo acesso à justiça e participação social;

II - economia judicial e processual; 
III - preservação da isonomia material;

IV - prioridade no processamento e duração razoável do processo;

V - máxima instrumentalidade, amplitude e utilidade da tutela jurisdicional coletiva;

VI - flexibilização e adequação da técnica processual;

VII - ativismo judicial;

VIII - motivação específica de todas as decisões judiciais, notadamente quanto aos conceitos jurídicos indeterminados;

IX - boa fé e responsabilidade das partes, procuradores e demais sujeitos que atuam no processo coletivo;

$\mathrm{X}$ - cooperação dos órgãos públicos na produção da prova;

XI - não taxatividade do objeto e dos meios de tutela dos direitos e interesses coletivos;

XII - publicidade e divulgação ampla das ações coletivas e dos seus principais atos processuais;

XIII - efetiva precaução, prevenção e reparação integral dos danos materiais e morais, individuais e coletivos, bem como a punição pelo enriquecimento ilícito;

XIV - preferência da execução coletiva;

XV - aplicabilidade residual, limitada e condicionada do Código de Processo Civil;

XVI - interpretação aberta e flexível dos princípios e regras desta lei e do sistema único coletivo;

\section{CAPÍTULO III - DA COMPETÊNCIA, DA CONEX̃̃O E DA LITISPENDÊNCIA}

Art. $6^{\circ}$. É competente para a causa o foro, sem prejuízo da regra da prevenção:

I - do lugar onde ocorreu ou deva ocorrer o dano ou o ato ilícito, quando de âmbito local;

II - de qualquer das comarcas ou subseção judiciária, quando o dano ou ato ilícito for de âmbito interestadual ou regional, assim entendido o que abrange até 5 (cinco) daquelas ou uma desta;

III - de uma das Capitais dos Estados afetados, quando o dano ou ato ilícito for de âmbito interestadual ou regional, assim entendido o que abrange 6 (seis) ou mais comarcas, 2 (duas) ou mais subsecções judiciárias (Comissão pede que seja revisto este critério);

Sugestão do Prof. Aluísio e ratificada pela Comissão.

II - de qualquer das comarcas ou subseções judiciárias, quando o dano for de âmbito interestadual ou regional, aplicando-se, no caso, as regras de prevenção;

III - de uma das Capitais dos Estados ou do Distrito Federal, quando o dano for de âmbito nacional, aplicando-se no caso as regras de prevenção;

IV - de uma das Capitais dos Estados ou do Distrito Federal, quando o dano ou ato ilícito for de âmbito nacional, assim entendido o que excede as regras precedentes.

$\S 1^{\circ}$. A extensão do dano será aferida conforme indicado na inicial.

A Comissão opina pela exclusão do parágrafo $1^{\circ}$.

$\S 2^{\circ}$ No caso de danos de âmbito nacional, interestadual e regional, o juiz competente poderá deprecar a realização da audiência preliminar e da instrução ao juízo mais próximo dos fatos.

Art. $7^{\circ}$. A distribuição de uma ação coletiva induzirá litispendência para as demais ações coletivas que tenham o mesmo pedido, causa de pedir e interessados e prevenirá a competência do juízo para todas as demais ações coletivas posteriormente intentadas que possuam a mesma causa de pedir ou o mesmo objeto, ainda que diferentes os legitimados coletivos, quando houver:

I - conexão, pela identidade de pedido ou causa de pedir ou da defesa, conquanto diferentes os legitimados;

II - conexão probatória; 
III - continência, pela identidade de interessados e causa de pedir, quando o pedido de uma das ações for mais abrangente do que o das demais.

$\S 1^{\circ}$. Na análise da identidade da causa de pedir e do objeto, será preponderantemente considerado o bem jurídico a ser protegido.

$\S 2^{\circ}$. Na hipótese de conexão ou continência entre ações coletivas que digam respeito ao mesmo bem jurídico, o juízo prevento, até o início da instrução, deverá determinar a reunião de processos para julgamento conjunto. Iniciada a instrução a reunião dos processos somente poderá ser determinada se não houver prejuízo para a duração razoável do processo.

Art. $8^{\circ}$. O ajuizamento de ações coletivas não induz litispendência para as correspondentes ações individuais, que tenham objeto correspondente, mas haverá a suspensão destas, até o julgamento da demanda coletiva em primeiro grau de jurisdição.

$\S 1^{\circ}$. Durante o período de suspensão, poderá o juiz perante o qual foi ajuizada a demanda individual conceder medidas de urgência.

$\S 2^{\circ}$. Cabe ao réu, na ação individual, informar o juízo sobre a existência de demanda coletiva que verse sobre idêntico bem jurídico, sob pena de, não o fazendo, o autor individual beneficiar-se da coisa julgada coletiva mesmo no caso de o pedido da ação individual ser improcedente.

$\S 3^{\circ}$. A ação individual somente poderá ter prosseguimento, a pedido do autor, se demonstrado mediante fundamentos idôneos a existência de graves prejuízos decorrentes da suspensão, caso em que não se beneficiará do resultado da demanda coletiva.

$\S 4^{\circ}$. A suspensão do processo individual perdurará até a prolação da sentença da ação coletiva, facultado ao autor, no caso de procedência desta e decorrido o prazo concedido ao réu para cumprimento da sentença, requerer a conversão da ação individual em liquidação provisória ou em cuprimento provisório da sentença coletiva, para apuração ou recebimento do valor ou pretensão a que faz jus.

$\S 5^{\circ}$. No prazo de 90 dias contados do trânsito em julgado da sentença coletiva, a ação individual suspensa será extinta, salvo se postulada a sua conversão em liquidação ou cumprimento de sentença coletiva.

$\S 6^{\circ}$. Transitada em julgado a sentença coletiva de improcedência do pedido que não seja fundada na insuficiência de prova, as ações individuais serão extintas.

$\S 7^{\circ}$. Em caso de julgamento de improcedência do pedido em ação coletiva por insuficiência de provas, a ação individual será extinta, salvo se não for requerido o prosseguimento no prazo de 90 dias contados do trânsito em julgado da sentença coletiva.

\section{CAPÍTULO IV - DA LEGITIMAÇÃO E POSTULAÇÃO NO PROCESSO COLETIVO}

Art. $9^{\circ}$. São legitimados concorrentemente para propor a ação coletiva:

I - o Ministério Público;

II - A Defensoria Pública;

III - as pessoas jurídicas de direito público interno, as entidades e órgãos despersonalizados da Administração Pública, direta ou indireta, que tenham em suas finalidades institucionais a defesa dos direitos coletivos, e as Mesas das Casas do Poder Legislativo;

IV - A Ordem dos Advogados do Brasil, inclusive as suas subsecções;

V - as entidades sindicais e de fiscalização do exercício das profissões, restritas as primeiras à defesa dos interesses e direitos difusos, coletivos e individuais ligados à categoria;

VI - os partidos políticos com representação no Congresso Nacional, nas Assembléias Legislativas ou nas Câmaras Municipais, conforme o âmbito do objeto da demanda;

VII - as associações civis e as fundações de direito privado legalmente constituídas e em funcionamento há pelo menos um ano, para a defesa de direitos e interesses dos seus fins institucionais, dispensadas a autorização assemblear ou pessoal e a apresentação do rol nominal dos associados ou membros. 
$\S 1^{\circ}$. O juiz poderá dispensar o requisito da pré-constituição das associações civis e das fundações de direito privado quando haja manifesto interesse social evidenciado pelas características do dano ou pela relevância do bem jurídico a ser protegido.

$\S 2^{\circ}$. O Ministério Público, se não intervier no processo como parte, atuará obrigatoriamente como fiscal da ordem jurídica.

$\S 3^{\circ}$. Admitir-se-á o litisconsórcio facultativo entre os legitimados, inclusive entre os Ministérios Públicos e as Defensorias Públicas

Art. 10. É vedada a intervenção de terceiros nas ações coletivas, fincando facultado a qualquer legitimado coletivo habilitar-se como assistente litisconsorcial de qualquer das partes. A apreciação do pedido de assistência far-se-á em autos apartados, sem suspensão do feito, recebendo o interveniente o processo no estado em que se encontre.

$\S 1^{\circ}$. O juiz rejeitará liminarmente o pedido de habilitação como assistente, do membro do grupo, na ação em defesa de interesses ou direitos individuais homogêneos, quando o interessado não demonstrar, de plano, razões de fato ou de direito que assegurem utilidade à tutela coletiva e justifiquem a sua intervenção, podendo o juiz limitar o número de assistentes, quando este comprometer o bom andamento e a duração razoável do processo.

$\S 2^{\circ}$. As pretensões individuais, na fase de conhecimento do processo coletivo, somente poderão ser discutidas e decididas de modo coletivo, facultando-se o agrupamento em subclasses ou grupos.

Art. 11. Em caso de desistência infundada, abandono da ação coletiva, ou não interposição do recurso de apelação, no caso de sentença de extinção ou improcedência do pedido, serão intimados pessoalmente o Ministério Público e outros legitimados conhecidos, sem prejuízo de ampla divulgação pelos meios de comunicação social, podendo qualquer legitimado assumir a titularidade.

Art. 12. Não haverá a extinção da ação coletiva, por ausência das condições da ação ou pressupostos processuais, sem que seja dada oportunidade de correção do vício em qualquer tempo ou grau de jurisdição ordinária ou extraordinária, inclusive a substituição do autor coletivo, quando serão intimados pessoalmente o Ministério Público e outros legitimados para a adoção das providências cabíveis, em prazo razoável, a ser fixado pelo juiz.

Art. 13.. Nas ações coletivas, para instruir a inicial o interessado poderá requerer de qualquer pessoa, física ou jurídica, indicando a finalidade, as certidões e informações que julgar necessárias, a serem fornecidas no prazo de 15 (quinze) dias.

$\S 1^{\circ}$. Não fornecidas as informações referidas no caput, poderá a parte propor a ação desacompanhada destas, cabendo ao juiz, após apreciar os motivos do indeferimento, requisitá-las.

$\S 2^{\circ}$. Constitui crime, punido com pena de reclusão de 1 (um) a 3 (três) anos, mais multa de 10 (dez) a 100 (cem) salários mínimos, a recusa, o retardamento ou a omissão de dados técnicos indispensáveis à propositura da ação civil, quando requisitados pelo juiz ou pelo Ministério Público.

Art. 14. Sendo incomensurável ou inestimável o valor dos direitos ou danos coletivos, o valor será indicado pelo legitimado coletivo, segundo critério de razoabilidade, com a fixação em definitivo pelo juiz na sentença.

Art. 15. Proposta a ação, deverá haver ampla divulgação pelos meios de comunicação social, a fim de que os legitimados e, em se tratando de tutela de interesses ou direitos individuais homogêneos, os membros do grupo possam ter ciência do seu ajuizamento, sem prejuízo da notificação dos órgãos e entidades de defesa dos interesses envolvidos na lide acerca da propositura da demanda.

Art. 16. A citação válida nas ações coletivas interrompe o prazo de prescrição das pretensões individuais direta ou indiretamente relacionadas com a controvérsia, até o final da demanda coletiva, ainda que haja a sua extinção sem resolução do mérito.

Art. 17. O juiz fixará o prazo para a resposta nas ações coletivas, que não poderá ser inferior a 20 (vinte) ou superior a 90 (noventa) dias, atendendo à complexidade da causa ou ao número de litigantes, não se aplicando as regras dos arts. 188 e 191 do Código de Processo Civil.

Art. 18. Nas ações coletivas, a requerimento do autor, em qualquer grau de jurisdição, o juiz ou tribunal poderá permitir a alteração do pedido ou da causa de pedir, desde que realizada de boa-fé e não importe 
prejuízo injustificado para a parte contrária, devendo ser preservado o contraditório, mediante a possibilidade de manifestação específica do réu, no prazo mínimo de quinze dias, facultada prova complementar.

$\S$ único. Ressalvada a ação de improbidade administrativa e a ação popular de proteção ao erário, a causa de pedir e o pedido serão interpretados extensivamente, em conformidade com o bem jurídico a ser protegido.

Art. 19. Se, no exercício de suas funções, os juízes e tribunais tiverem conhecimento de fatos que possam ensejar a propositura da ação coletiva, inclusive a existência de diversos processos individuais correndo contra o mesmo demandado, com identidade de fundamento jurídico, oficiará o Ministério Público, com remessa de cópia ao órgão superior competente e, na medida do possível, outros legitimados, a fim de que proponham, querendo, demanda coletiva.

$\S$ único. Qualquer pessoa poderá e o servidor público deverá provocar a iniciativa do Ministério Público, ou de qualquer outro legitimado, ministrando-lhe informações sobre fatos que constituam objeto da ação coletiva e indicando-lhe os elementos de convicção.

Art. 20. Sendo relevante o fundamento da demanda e havendo justificado receio de ineficácia do provimento final, bem como nas hipóteses de abuso do direito de defesa ou da existência de parte incontroversa da demanda, é lícito ao juiz conceder a tutela liminarmente ou após justificação prévia.

$\S 1^{\circ}$. Independentemente de pedido do autor, o juiz poderá, no momento da tutela liminar ou da sentença, impor ao réu multa, suficiente e compatível com a tutela, observada a capacidade econômica do demandado, fixando prazo razoável para o cumprimento do preceito.

$\S 2^{\circ}$. Alternativa ou cumulativamente com a multa prevista no parágrafo anterior, o juiz poderá determinar a aplicação de medidas subrogatórias ou de indução suficientes ou necessárias para impor o cumprimento da prestação, tais como busca e apreensão, remoção de coisas e pessoas, desfazimento de obra, impedimento de atividade nociva, intervenção em pessoas jurídicas, requisição de força policial e prisão civil na hipótese de descumprimento de dever alimentar.

§3․ A multa cominada liminarmente será devida desde o dia em que se houver configurado o descumprimento e poderá ser exigida de forma imediata, em autos apartados, por meio de execução definitiva.

$\S 4^{\circ}$. O juiz poderá impor multa pessoal contra o agente público ou representante da pessoa jurídica de direito privado responsável pelo cumprimento da decisão que impôs a obrigação, observada a necessidade de intimação pessoal.

\section{CAPÍTULO V - DO SANEAMENTO E PROVA NO PROCESSO COLETIVO}

Art. 21. Encerrada a fase postulatória, o juiz designará audiência preliminar, à qual comparecerão as partes ou seus procuradores, habilitados a transigir.

$\S$ 1o. O juiz ouvirá as partes sobre os motivos e fundamentos da demanda e tentará a conciliação, sem prejuízo de outras formas adequadas de solução do conflito, como a mediação, a arbitragem e a avaliação neutra de terceiro, observada a natureza disponível do direito em discussão.

$\S 2^{\circ}$. A avaliação neutra de terceiro, de confiança das partes, obtida no prazo fixado pelo juiz, é sigilosa, inclusive para este, e não vinculante para as partes, tendo por finalidade exclusiva orientá-las na tentativa de composição amigável do conflito.

$\S 30$. Preservada a indisponibilidade do bem jurídico coletivo, as partes poderão transigir sobre o modo de cumprimento da obrigação.

$\S 4^{\circ}$. Obtida a transação, será homologada por sentença, que constituirá título executivo judicial.

$\S 5^{\circ}$. Não obtida a conciliação ou quando, por qualquer motivo, não for utilizado outro meio de solução do conflito, o juiz, fundamentadamente:

I - decidirá se o processo tem condições de prosseguir na forma coletiva;

II - poderá separar os pedidos em ações coletivas distintas, voltadas à tutela, respectivamente, dos interesses ou direitos difusos e coletivos, de um lado, e dos individuais homogêneos, do outro, desde que a separação represente economia processual ou facilite a condução do processo; 
III - decidirá a respeito do litisconsórcio e da assistência;

IV - fixará os pontos controvertidos, decidirá as questões processuais pendentes e determinará as provas a serem produzidas;

V - distribuirá a responsabilidade pela produção da prova, levando em conta os conhecimentos técnicos ou informações específicas sobre os fatos detidos pelas partes ou segundo a maior facilidade em sua demonstração:

VI - poderá ainda distribuir essa responsabilidade segundo os critérios previamente ajustados pelas partes, desde que esse acordo não torne excessivamente difícil a defesa do direito de uma delas.

VII - poderá, a todo momento, rever a decisão de distribuição da responsabilidade da produção da prova, diante de fatos novos.

VIII - esclarecerá as partes sobre a distribuição do ônus da prova.

IX - poderá determinar de ofício a produção de provas, observado o contraditório.

Art. 25. Em sendo necessária a realização de prova pericial requerida pelo legitimado ou determinada de ofício, o juiz nomeará o perito, preferencialmente, dentre servidores públicos especializados na matéria da prova.

$\S$ único. Em não havendo servidor público apto a desempenhar a função pericial a que alude o parágrafo anterior, competirá ao Poder Público remunerar o trabalho do perito judicial, após a devida requisição judicial.

Art. 22 (era o inciso IX do art. 16) - Se não houver necessidade de audiência de instrução e julgamento, de acordo com a natureza do pedido e as provas documentais juntadas pelas partes ou requisitadas pelo juiz, sobre as quais tenha incidido o contraditório, simultâneo ou sucessivo, o juiz julgará antecipadamente a lide.

Art. 23. (obs: sugestão de redação). Em qualquer tempo e grau do procedimento, o juiz ou tribunal poderá submeter a questão objeto da ação coletiva a audiências públicas, ouvindo especialistas no assunto e membros da sociedade, de modo a garantir a mais ampla participação social possível e a adequada cognição judicial.

\section{CAPÍTULO VI - DAS DECISÕES NO PROCESSO COLETIVO}

Art. 24. Na ação que tenha por objeto a imposição de conduta de fazer, de não fazer, pagar ou de entregar coisa, o juiz determinará a prestação ou a abstenção devida, bem como a cessação da atividade nociva, em prazo razoável, sob pena de cominação de medida subrogatória ou de indução, independentemente de requerimento do autor.

$\S 1^{\circ}$. A conversão em perdas e danos somente será admissível se inviável a tutela específica ou a obtenção do resultado prático correspondente e, no caso de interesses ou direitos coletivos ou individuais homogêneos, se houver interesse do grupo titular do direito.

$\S 2^{\circ}$. A indenização por perdas e danos se fará sem prejuízo da multa, quando cabível.

Art. 25. Na ação reparatória dos danos provocados ao bem indivisivelmente considerado, sempre que possível e independentemente de pedido do autor, a condenação consistirá na prestação de obrigações específicas, destinadas à reconstituição do bem, mitigação e/ou compensação do dano sofrido.

$\S$ único. Dependendo das características do bem jurídico afetado, da extensão territorial abrangida e de outras circunstâncias, o juiz poderá determinar, em decisão fundamentada e independentemente do pedido do autor, as providências a serem tomadas para a reconstituição dos bens lesados, podendo indicar a realização de atividades tendentes a minimizar a lesão ou a evitar que se repita, dentre outras que beneficiem o bem jurídico prejudicado.

Art. 26. Na ação que tenha por objeto a condenação ao pagamento de quantia em dinheiro, deverá o juiz, sempre que possível, em se tratando de valores a serem individualmente pagos aos prejudicados ou de valores devidos coletivamente, impor a satisfação desta prestação de ofício e independentemente de execução, valendo-se da imposição de multa e de outras medidas indutivas, coercitivas e subrogatórias. 
$\S 1^{\circ}$. Quando a execução envolver parcelas ou prestações individuais, sempre que possível o juiz determinará ao réu que promova dentro do prazo fixado o pagamento do valor da dívida, sob pena de multa e de outras medidas, independentemente de habilitação judicial dos interessados.

$\S 2^{\circ}$. Para fiscalizar os atos de liquidação e cumprimento da sentença coletiva poderá o juiz nomear pessoa qualificada, que terá acesso irrestrito ao banco de dados e à documentação necessária ao desempenho da função.

$\S 3^{\circ}$. Na sentença condenatória à reparação pelos danos individualmente sofridos, sempre que possível, o juiz fixará o valor da indenização individual devida a cada membro do grupo ou um valor mínimo para a reparação do dano.

$\S 4$ o. Quando o valor dos danos individuais sofridos pelos membros do grupo for uniforme, prevalentemente uniforme ou puder ser reduzido a uma fórmula matemática, a sentença coletiva indicará o valor ou a fórmula de cálculo da indenização individual e determinará que o réu promova, no prazo que fixar, o pagamento do valor respectivo a cada um dos membros do grupo.

$\S 5^{\circ}$. O membro do grupo que divergir quanto ao valor da indenização individual ou à fórmula para seu cálculo, estabelecidos na sentença coletiva, poderá propor ação individual de liquidação, no prazo de um ano, contado do trânsito em julgado da sentença coletiva.

$\S 6^{\circ}$. Se for no interesse do grupo titular do direito, as partes poderão transacionar, após a oitiva do Ministério Público, ressalvada aos membros do grupo, categoria ou classe a faculdade de não aderir à transação, resguardado o direito de propor ação individual no prazo de um ano, contado do trânsito em julgado da sentença homologatória.

Art. 27 Não sendo possível a prolação de sentença condenatória líquida, a condenação poderá ser genérica, fixando a responsabilidade do demandado pelos danos causados e o dever de indenizar.

\section{CAPÍTULO VII - DOS RECURSOS E DA COISA JULGADA COLETIVA}

Art. 28. O recurso interposto contra a sentença coletiva será recebido no efeito meramente devolutivo, salvo quando sua fundamentação for relevante e puder resultar lesão grave e de difícil reparação, hipótese em que o juiz, ponderando os valores em questão e a requerimento do interessado, poderá atribuir-lhe o efeito suspensivo.

Art. 29. A sentença coletiva fará coisa julgada erga omnes, independentemente da competência territorial do órgão prolator ou do domicílio dos interessados.

$\S 1^{\circ}$. Se o pedido for julgado improcedente por insuficiência de provas, qualquer legitimado poderá ajuizar outra ação, com idêntico fundamento, valendo-se de nova prova.

$\S 2^{\circ}$ Os efeitos da coisa julgada coletiva na tutela de direitos individuais homogêneos não prejudicarão interesses e direitos individuais dos integrantes da coletividade, do grupo, categoria ou classe, que poderão propor ações individuais em sua tutela, desde que o pedido no processo coletivo tenha sido julgado improcedente por insuficiência de prova.

$\S 3^{\circ}$. Nas ações coletiva que tenham por objeto direitos ou interesses difusos ou coletivos, as vítimas e seus sucessorespoderão proceder à liquidação e o cumprimento da sentença, quando procedente o pedido.

$\S 4^{\circ}$ Aplica-se a regra do $\S 3^{\circ}$ à sentença penal condenatória.

Art. 25. Na hipótese de sentença de improcedência, fundada na insuficiência de provas produzidas, qualquer legitimado poderá intentar outra ação, com idêntico fundamento, no prazo de 180 (cento e oitenta) dias contados do conhecimento geral da descoberta de prova técnica nova, superveniente, que não poderia ser produzida no processo, desde que idônea para mudar seu resultado.

$\S 1^{\circ}$ A faculdade prevista no caput, nas mesmas condições, fica assegurada ao demandado da ação coletiva com pedido julgado procedente, caso em que a decisão terá efeitos ex nunc.

$\S 2^{\circ}$ Para admissibilidade da ação prevista no parágrafo anterior, deverá o autor depositar valor a ser arbitrado pelo juiz, que não será inferior a $10 \%$ (dez porcento) do conteúdo econômico da demanda, revertendo na hipótese de improcedência em favor do Fundo de Direitos Difusos, Coletivos e Individuais Homogêneos. 


\section{CAPÍTULO VIII - DA LIQUIDAÇÃO, EXECUÇÃO E CUMPRIMENTO DE SENTENÇAS COLETIVAS}

Art. 26. É competente para a liquidação e execução coletiva o juízo da ação condenatória, o foro do local onde se encontrem bens sujeitos à expropriação ou do domicílio do executado.

$\S$ único. Sempre que possível, a liquidação e a execução serão coletivas, sendo promovidas por qualquer dos legitimados à ação coletiva.

Art. 26. É competente para a liquidação e execução individual o foro do domicílio do autor da liquidação ou da execução e do local onde se encontrem bens sujeitos à expropriação.

$\S 1^{\circ}$. Quando a competência para a liquidação não for do juízo da fase de conhecimento, o executado será intimado, na pessoa do seu procurador, seguindo a execução o procedimento do art. 475-A e seguintes do Código de Processo Civil.

$\S 2^{\circ}$. Na hipótese do $\S 1^{\circ}$ o executado será intimado para a execução após a penhora.

Art. 27. A liquidação e a execução de sentença coletiva poderão ser promovidas pelos legitimados coletivos, pela vítima ou seus sucessores.

Art. 28. Na liquidação da sentença condenatória à reparação dos danos individualmente sofridos, deverão ser provados, tão só, o dano pessoal, o nexo de causalidade e o montante da indenização.

Art. 29. A liquidação da sentença poderá ser dispensada quando a apuração do dano pessoal, do nexo de causalidade e do montante da indenização depender exclusivamente de prova documental, hipótese em que o pedido de execução por quantia certa será acompanhado dos documentos comprobatórios e da memória do cálculo.

Art. 30. Os valores destinados ao pagamento das indenizações individuais serão depositados, preferencialmente, em instituição bancária oficial, abrindo-se conta remunerada e individualizada para cada beneficiário, regendo-se os respectivos saques, pelas normas aplicáveis aos depósitos bancários, determinando-se ao réu, além da ampla divulgação nos meios de comunicação, a comprovação da realização dos depósitos individuais e a notificação aos beneficiários com endereço conhecido.

Art. 30. Decorrido o prazo de um ano, contado da prolação da sentença condenatória genérica de danos sofridos por sujeitos indeterminados, seja em função da não habilitação de interessados em número compatível com a gravidade do dano, seja em função do locupletamento indevido do réu, poderão os legitimados coletivos promover a liquidação e execução da indenização pelos danos globalmente sofridos pelos membros do grupo, sem prejuízo do correspondente ao enriquecimento ilícito do réu, devendo o valor reverter para o Fundo de Direitos Difusos, Coletivos e Individuais Homogêneos.

$\S 1^{\circ}$. Não correrá a prescrição durante a fluência do prazo previsto no caput deste artigo.

$\S 2^{\circ}$. Enquanto não se consumar a prescrição da pretensão individual, fica assegurado o direito de exigir o pagamento pelo Fundo, limitado o total das indenizações ao valor que lhe foi recolhido e vinculado à ação originária.

$\S 3^{\circ}$. No caso do parágrafo $2^{\circ}$, o juiz da execução poderá autorizar a habilitação dos créditos dos prejudicados diretamente junto ao Fundo de Direitos Difusos, Coletivos e Individuais Homogêneos, provando o dano pessoal, o nexo de causalidade e o montante da indenização.

$\S 4^{\circ}$. No caso de concurso de créditos decorrentes de ações em defesa de interesses ou direitos individuais homogêneos, coletivos e difusos, a preferência com relação ao pagamento será decidida pelo juiz aplicando os princípios da proporcionalidade e da razoabilidade.

$\S 5^{\circ}$ Para efeito do disposto no parágrafo $4^{\circ}$, a destinação da importância recolhida ao Fundo de Direitos Difusos, Coletivos e Individuais Homogêneos ficará sustada enquanto pendentes de decisão final as liquidações individuais, salvo na hipótese de o patrimônio do devedor ser manifestamente suficiente para responder pela integralidade dos prejuízos causados às vítimas. 


\section{CAPÍTULO IX - DO FUNDO DOS DIREITOS DIFUSOS, COLETIVOS E INDIVIDUAIS HOMOGÊNEOS}

Art. 31. Havendo condenação em pecúnia, inclusive decorrente de dano moral coletivo, originária de ação coletiva, relacionada com direitos ou interesses difusos, a quantia reverterá ao Fundo de Direitos Difusos, Coletivos e Individuais Homogêneos gerido por um Conselho Federal ou por Conselhos Estaduais de que participarão necessariamente o Ministério Público, a Defensoria Pública e representantes da comunidade, sendo seus recursos destinados à reconstituição dos bens lesados.

Art. 32. Os recursos do Fundo serão destinados à realização de atividades tendentes a minimizar as lesões ou a evitar que se repitam, dentre outras que beneficiem os bens jurídicos prejudicados. O Fundo poderá também antecipar os custos de perícias e gastos em ações coletivas e viabilizar a execução de obrigação de fazer a ser prestada por terceiro às custas do obrigado.

Art. 33. Além da indenização coletiva, constituem receitas do Fundo, dentre outras, o ressarcimento das despesas com perícias e os gastos antecipados, o produto da arrecadação de multas, inclusive as decorrentes do descumprimento de compromissos de ajustamento de conduta.

Art. 35. O representante legal do Fundo, considerado agente público para efeitos legais, responderá por sua atuação nas esferas administrativa, penal e civil.

Art. 36. O Fundo manterá e divulgará registros que especifiquem a origem e a destinação dos recursos e dará publicidade às suas demonstrações financeiras e atividades desenvolvidas semestralmente, inclusive por meio de portal na rede mundial de computadores.

Art. 37. O Fundo de Direitos Difusos, Coletivos e Individuais Homogêneos será regulamentado pelo Poder Executivo no prazo de 90 (noventa) dias.

\section{CAPÍTULO X - DO TERMO DE AJUSTAMENTO DE CONDUTA E DO INQUÉRITO CIVIL}

Art. 38. Os órgão públicos legitimados, poderão tomar dos interessados compromisso de ajustamento de sua conduta às exigências legais, mediante fixação de modalidades e prazos para o cumprimento das obrigações assumidas e de multas por seu descumprimento.

Art. 39. O valor da cominação pecuniária deverá ser suficiente e necessário para coibir o descumprimento da medida pactuada. A cominação poderá ser executada imediatamente, sem prejuízo da execução específica.

Art. 40. O termo de ajustamento de conduta terá natureza jurídica de transação, com eficácia de título executivo extrajudicial, sem prejuízo da possibilidade da sua homologação judicial, hipótese em que sua eficácia será de título executivo judicial.

Art. 41. O Ministério Público poderá instaurar, sob sua presidência, inquérito civil, ou requisitar, de qualquer organismo público ou particular, certidões, informações, exames ou perícias, no prazo que assinalar, o qual não poderá ser inferior a $10(\mathrm{dez})$ dias úteis.

$\S$ único. É autorizada a instauração de inquérito civil fundamentado em denúncia anônima, somente se instruída com elementos mínimos de convicção.

Art. 42. Se, depois de esgotadas todas as diligências, o órgão do Ministério Público se convencer da inexistência de fundamento para a propositura da ação coletiva, promoverá o arquivamento dos autos do inquérito civil ou das peças informativas, fazendo-o fundamentadamente, sem prejuízo da atuação dos demais co-legitimados com relação ao mesmo objeto.

$\S 1^{\circ}$. Os autos do inquérito civil ou das peças de informação arquivadas serão remetidos ao órgão revisor competente, conforme dispuser o seu Regimento, no prazo de até 15 (quinze) dias, sob pena de se incorrer em falta grave.

$\S 2^{\circ}$. Até que o órgão revisor homologue ou rejeite a promoção de arquivamento, poderão os interessados apresentar razões escritas ou documentos, que serão juntados aos autos do inquérito ou anexados às peças de informação.

$\S 3^{\circ}$. Deixando o órgão revisor de homologar a promoção de arquivamento, designará, desde logo, outro órgão do Ministério Público para o ajuizamento da ação ou a adoação de outras providências cabíveis e manifestação fundamentada. 


\section{CAPÍTULO XI - DO CADASTRO NACIONAL DE PROCESSOS COLETIVOS E DO CADASTRO NACIONAL DE INQUÉRITOS CIVIS E TERMOS DE AJUSTAMENTO DE CONDUTA}

Art. 43. O Conselho Nacional de Justiça organizará e manterá o Cadastro Nacional de Processos Coletivos, com a finalidade de permitir que os órgãos do Poder Judiciário e os interessados tenham amplo acesso às informações relevantes relacionadas com a existência e o estado das ações coletivas.

$\S 1^{\circ}$. Os órgãos judiciários aos quais forem distribuídos processos coletivos remeterão, no prazo de 10 (dez) dias, cópia da petição inicial, preferencialmente por meio eletrônico, ao Cadastro Nacional de Processos Coletivos.

$\S 2^{\circ}$. No prazo de 90 (noventa) dias, o Conselho Nacional de Justiça, editará regulamento dispondo sobre o funcionamento do Cadastro Nacional de Processos Coletivos e os meios adequados a viabilizar o acesso aos dados e seu acompanhamento por qualquer interessado através da rede mundial de computadores. O regulamento disciplinará a forma através da qual os juízos comunicarão a existência de processos coletivos e os atos processuais mais relevantes sobre o seu andamento, como a concessão de antecipação de tutela, a sentença, o trânsito em julgado, a interposição de recursos e a execução.

Art. 44. O Conselho Nacional do Ministério Público organizará e manterá o Cadastro Nacional de Inquéritos Civis e de Termos de Ajustamento de Conduta, com a finalidade de permitir que os órgãos do Poder Judiciário, os co-legitimados e os interessados tenham amplo acesso às informações relevantes relacionadas com a abertura do inquérito e a existência do Termo.

$\S 1^{\circ}$. Os órgãos legitimados que tiverem realizado termos de ajustamento de conduta remeterão, no prazo de 10 (dez) dias, cópia, preferencialmente por meio eletrônico, ao Cadastro Nacional de Inquéritos Civis e de Termos de Ajustamento de Conduta.

$\S 2^{\circ}$. O Conselho Nacional do Ministério Público, no prazo de 90 (noventa) dias, editará regulamento dispondo sobre o funcionamento do Cadastro Nacional de Inquéritos Civis e Termos de Ajustamento de Conduta, incluindo a forma de comunicação e os meios adequados a viabilizar o acesso aos dados e seu acompanhamento por qualquer interessado.

\section{CAPÍTULO XII - DISPOSIÇÕES FINAIS}

Art. 41. As ações coletivas terão tramitação prioritária sobre as demandas individuais.

Art. 42. A sentença coletiva condenará o demandado, se vencido, ao pagamentos das custas, emolumentos, honorários periciais e quaisquer outras despesas, bem como dos honorários de advogado, calculados sobre a condenação.

$\S 1^{\circ}$ Tratando-se de condenação a obrigação específica ou de condenação genérica, os honorários advocatícios serão fixados levando-se em consideração a vantagem obtida para os interessados, a quantidade e qualidade do trabalho desenvolvido pelo advogado e a complexidade da causa.

$\S 2^{\circ}$ Os legitimados coletivos não adiantarão custas, emolumentos, honorários periciais e quaisquer outras despesas, nem serão condenados em honorários de advogados, custas e demais despesas processuais, salvo comprovada má-fé.

Art. 43. O legitimado coletivo somente responde por danos processuais nas hipóteses em que agir com má-fé processual.

§ único. O litigante de má-fé e os responsáveis pelos respectivos atos, serão solidariamente condenados ao pagamento das despesas processuais, em honorários advocatícios e em até o décuplo das custas, sem prejuízo da responsabilidade por perdas e danos.

Art. 44. Quando se tratar de ação coletiva ajuizada por fundação privada, sindicato ou associação, deverá o juiz fixar, em caso de procedência do pedido, gratificação financeira, por equidade, levando em consideração a participação do legitimado na descoberta do ilícito e na resolução do conflito, a sua adequada atuação, entre outros fatores que demonstrem a utilidade de sua participação e a sua conduta exemplar, sem prejuízo da verba honorária que não poderá ser inferior à gratificação financeira.

Art. 45. A ação rescisória objetivando desconstituir sentença ou acórdão de ação coletiva deverá ser ajuizada em face do legitimado coletivo que tenha ocupado o pólo ativo originariamente, podendo os demais co- 
legitimados atuarem como assistentes. Na sua impossibilidade, a ação rescisória coletiva será ajuizada em face do Ministério Público.

Parágrafo único. No caso de ausência de resposta, deverá o Ministério Público ocupar o pólo passivo, renovando-se-lhe o prazo para responder.

Art. 49. A União, no prazo de seis meses, o Distrito Federal e os Estados criarão, em primeira e segunda instância, juízos e órgãos especializados para o processamento e julgamento de ações coletivas, ressalvada a competência específica em razão da matéria.

Art. 50. Aplica-se à ação civil pública e às demais ações coletivas, previstas nesta Lei, o Código de Processo Civil, aprovado pela Lei no 5.869 , de 11 de janeiro de 1973, naquilo em que não contrarie suas disposições.

Art. 51. Os dispositivos desta lei aplicam-se no âmbito das relações de trabalho, ressalvadas as peculariedades e os princípios informadores do processo trabalhista.

Art. 52. Revogam-se todas as disposições da Lei n. 7.347/85 - Lei da Ação Civil Pública; os arts. 81, 82, 83. 84, 87, 88, 90, 91, 92, 93, 94, 95, 97, 98, 99, 100, 101, 102, 103 e 104 da Lei n. 8.078/90 - Código de Defesa do Consumidor; os arts. 74, inciso I, 80, 81, 82, 83, 84, 85, 86, 87, 88, 89, 92, da Lei 10.471 , de $1^{\circ}$ de outubro de 2003 - Estatuto do Idoso; os arts. 209, 210, 211, 212, 213, 215, 216, 217, 218, 219, 220, 221, 222, 223, da Lei n. 8.069/90 - Estatuto da Criança e do Adolescente.

Art. 53. Esta lei entrará em vigor dentro de cento e oitenta dias a contar de sua publicação. 
Oupremo OFitunal OFedexal

COORD. DE ANÁLISE DE JURISPRUDÊNCIA

D.J. 29.06.2007

EMENTÁRIO No 2282 - 11

EMB.DECL.NO AG.REG.NO RECURSO EXTRAORDINÁRIO 470.135-9 MATO GROSSO

RELATOR

EMBARGANTE(S)

ADVOGADO(A/S)

ADVOGADO(A/S)

EMBARGADO(A/S)

\author{
MIN. CEZAR PELUSO \\ CAIXA ECONÔMICA FEDERAL - CEF \\ EDUARDO ARRUDA ALVIM \\ JOSÉ MANOEL DE ARRUDA ALVIM E \\ OUTRO(A/S) \\ : MINISTÉRIO PÚBLICO FEDERAL
}

EMENTAS: 1. LEGITIMIDADE PARA A CAUSA. Ativa. Caracterização. Ministério Público. Ação civil pública. Demanda sobre contratos de financiamento firmados no âmbito do Sistema Financeiro da Habitação - SFH. Tutela de diretos ou interesses indivicluais homogêneos. Matéria de alto relevo social. Pertinência ao perfil institucional do MP. Inteligência dos arts. 127 e 129, incs. III e IX, da CF. Precedentes. O Ministério público tem legitimação para ação civil pública em tutela de interesses individuais homogêneos dotados de alto relevo social, como os de mutuários em contratos de financiamento pelo Sistema Financeiro da Habitação.

2.

RECURSO. Embargos de declaração. Acórdão. Correção de erro material na ementa. Revogação de condenação ao pagamento de multa por litigância de má-fé. Embargos acolhidos, em parte, para esses fins. Embargos de declaração servem para corrigir erro material na redação da ementa do acórdão embargado, bem como para excluir condenação ao pagamento de multa, quando descaracterizada litigância de má-fe.

\section{$\underline{A} \underline{\mathrm{C}} \underline{\underline{B}} \underline{\mathrm{B}} \underline{\mathrm{A}} \underline{\mathrm{O}}$}

Vistos, relatados e discutidos estes autos, acordam os Ministros da Segunda Turma do Supremo Tribunal Federal, sob a Presidência do Senhor Ministro CELSO DE MELLO, na conformidade da ata de julgamento e das notas taquigráficas, por unanimidade de votos, em acolher, em parte, os embargos de declaração, nos termos do voto do Relator.

Brasília, 22 de maio de 2007.

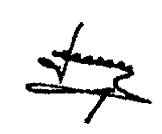

Ministro CEZAR PELUSO Relator

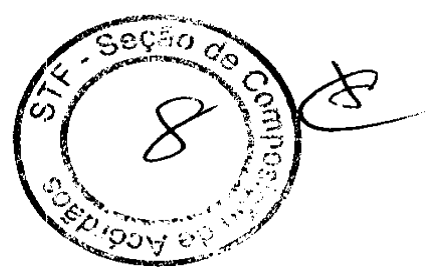


EMB.DECL.NO AG.REG.NO RECURSO EXTRAORDINÁRIO 470.135-9 MATO GROSSO

RELATOR

EMBARGANTE(S)

ADVOGADO(A/S)

ADVOGADO(A/S)

EMBARGADO(A/S)

\author{
MIN. CEZAR PELUSO \\ CAIXA ECONÔMICA FEDERAL - CEF \\ EDUARDO ARRUDA ALVIM \\ JOSÉ MANOEL DE ARRUDA ALVIM E \\ OUTRO(A/S) \\ : MINISTÉRIO PÚBLICO FEDERAL
}

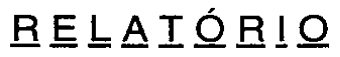

\section{O SENHOR MINISTRO CEZAR PELUSO - (Relator): Trata-se} de embargos de declaração opostos pela Caixa Econônica Federal contra acórdão assim ementado:

“1. RECURSO. Extraordinário. Inadmissibilidade. Ministério Público. Legitimidade ativa. Ação civil pública. Anulação de contrato de prestação de serviços. Sistema Único de Saúde - SUS. Inobservância do procedimento licitatório. Jurisprudência assentada. Ausência de razões novas. Decisão mantida. Agravo regimental improvido. Nega-se provimento a agravo regimental tendente a impugnar, sem razões novas, decisão fundada em jurisprudência assente na Corte.

2. RECURSO. Agravo. Regimental. Jurisprudência assentada sobre a matéria. Caráter meramente abusivo. Litigância de má-fé. Imposição de multa. Aplicação do art. $557, \mathbb{} 2^{\circ}$, cc. arts. 14, II e III, e 17, VII, do CPC. Quando abusiva a interposição de agravo, manifestamente inadmissível ou infundado, deve o Tribunal condenar 0 agravante a pagar multa ao agravado (fls. 533)".

Alega a embargante, em síntese, que tal acórdão padeceria de omissão e contradição. A Corte teria deixado de se pronunciar sobre a questão ventilada no recurso extraordinário, atinente à ilegitimidade do Ministério Público 
para tutelar em juízo direitos e interesses individuais homogêneos ligados a contratos de financiamento firmados no âmbito do Sistema Financeiro da Habitação. Além disso, a ementa do julgamento teria feito referência a situação diversa da contida nos autos. Em razão disso, entende a embargante que seria descabida sua condenação nas sanções da litigância de má-fé (fls. 538/548).

É o relatório. 


\section{$\underline{\mathrm{V}} \underline{\mathrm{O}} \underline{\mathrm{O}}$}

O SENHOR MINISTRO CEZAR PELUSO - (Relator): 1. Não há omissão no acórdão embargado.

A questão, devolvida ao conhecimento da Corte por meio do recurso extraordinário e atinente à legitimidade do Ministério Público para propositura de ação civil pública em defesa de direitos individuais homogêneos, foi desatada com base em jurisprudência aplicável in totum ao caso.

Com efeito, os precedentes - alguns dos quais constam do acórdão embargado - demonstram que o Supremo Tribunal Federal reconhece a legitimação ad causam do Ministério Público, assim para a tutela de interesses e direitos difusos e coletivos - os transindividuais de natureza indivisível -, como para a proteção de direitos individuais homogêneos, sempre que estes, tomados em conjunto, ostentem dimensão de grande relevo social, ligada a valores e preceitos que, hospedados na Constituição da República Federal, sejam pertinentes a toda a coletividade. Nesses casos, a atuação do Ministério Público afeiçoa-se a seu perfil institucional, voltado ao resguardo do interesse social e dos direitos coletivos, considerados em sentido amplo (CF, art. 127 e 129, incs. III e IX). Confira-se:

"RECURSO EXTRAORDINÁRIO. CONSTITUCIONAL. LEGITIMIDADE DO MINISTÉRIO PÚBLICO PARA PROMOVER AÇÃO CIVIL PÚBLICA EM DEFESA DOS INTERESSES DIFUSOS, COLLTIVOS E HOMOGENEOS. MENSALIDADES ESCOLARES: CAPACIDADE POSTULATÓRIA DO PARQUET PARA DISCUTILAS EM JUIZZO.

(...) 
4. Direitos ou interesses homogêneos são os que tem a mesma orige m comum (art. 81, III, da Lei n. 8.078, de 11 de setembro de 1990), constituindo-se em subespécie de direitos coletivos.

4.1. Quer se afirme interesses coletivos ou particularmente interesses homogêneos, stricto sensu, ambos estão cingidos a unna mesma base jurídica, sendo coletivos, explicitamente dizendo, porque são relativos a grupos, categorias ou classes de pessoas, que conquanto digam respeito as pessoas isoladamente, não se classificam como direitos individuais para o fim de ser vedada a sua defesa em ação civil pública, porque sua concepção finalística destina-se a proteção desses grupos, categorias ou classe de pessoas.

5. As chamadas mensalidades escolares, quando abusivas ou ilegais, podem ser impugnadas por via de ação civil pública, a requerimento do Órgão do Ministério Público, pois ainda que sejam interesses homogêneos de origem comum, são subespécies de interesses coletivos, tutelados pelo Estado por esse meio processual como dispõe o artigo 129, inciso III, da Constituição Federal.

5.1. Cuidando-se de tema ligado a educação, amparada constitucionalmente como dever do Estado e obrigação de todos (CF, art. 205), está o Ministério Público investido da capacidade postulatória, patente a legitimidade ad causam, quando o bem que se busca resguardar se insere na órbita dos interesses coletivos, em segmento de extrema delicadeza e de conteúdo social tal que, acima de tudo, recomenda-se o abrigo estatal. Recurso extraordinário conhecido e provido para, afastada a alegada ilegitimidade do Ministério Público, corn vistas a defesa dos interesses de uma coletividade, determinar a remessa dos autos ao Tribunal de origem, para prosseguir no julgamento da ação" (RE no 163.231, rel. Min. MAURÍcIO CORRÊA, DJ de 29.06.2001).

"A ação civil pública presta-se a defesa de direitos individuais homogêneos, legitimado o Ministério Público para aforá-la, quando os titulares daqueles interesses ou direitos estiverem na situação ou na condição de consumidores, ou quando houver uma relação de consumo. (...) Certos direitos individuais homogêneos podem ser classificados como interesses ou direitos coletivos, ou identificar-se com interesses sociais e individuais indisponíveis. Nesses casos, a ação civil pública presta-se a defesa dos mesmos, legitimado o Ministério Público para a causa. C. F., art. 127, caput, e a rt. 129, III". (RE n. 195.056, Rel. Min. CARLOS VELLOSO, DJ 30.05.2003. No mesmo sentido, cf. Al-AgR n. 491.195, Rel. Min. SEPÚlVEDA PERTENCE, DJ 07.05.2004; RE-AgR n. 424.048, Rel. Min. SEPÚLVEDA PERTENCE, DJ 25.11.2005; Al-AgR n. 438.703, Rel. Min. ELLEN GRACIE, DJ 05.05.2006). 
No tocante aos interesses dos mutuários do Sistema Financeiro

da Habitação, veja-se este precedente:

"No caso, a ação civil pública tem por objeto direitos individuais homogêneos, cujos titulares estão na situação ou na condição de consumidores, entendida a expressão no seu sentido largo: têm-se, no caso, interessados na aquisição de casa própria, dos quais está-se cobrando um certo preço pela distribuição de informativos ou inscrição em programa habitacional.

No caso, portanto, o Ministério Público está legitimado para a ação, com base na legislação infraconstitucional (Lei 7.347/85, art. $1^{\circ}$, II, e art. 21, com a redação do art. 117 da Lei 8.078/90; Lei 8.625, de 1993, art. 25).

Mas não é só.

$\hat{E}$ que certos direitos individuais homogêneos, tendo em consideração a sua natureza e desde que visualizados de forma abrangente, podem ser tidos como espécie de interesses ou direitos coletivos. Se se tem presente, por exemplo, a relevância que a Constituição empresta à moradia, consagrada como direito social, assim direito fundamental, CF, art. $6^{\circ}$, redação da EC 26 , de 2000 , a interpretação abrangente, ora preconizada, tal como preconizamos relativamente à educação, no acórdão do RE 195.056/PR, linhas atrás indicado, para o fim de tomar o órgão do Ministério Público legitimado para a defesa do direito ou interesse aqui discutido, decorrente de um direito fundamental, ajusta-se ao espírito da Carta, porque confere maior eficácia aos princípios por ela consagrados.

Do exposto, conheço do recurso e dou-lhe provimento." (RE n. 247.134, Rel. Min. CARLOS VELLOSO, DJ 09.12.2005).

Correto, no ponto, o parecer da Procuradoria-Geral da

República, sintetizado no seguinte trecho da ementa:

“Constitucional. Legitimação do Ministério Público para a tutela de interesses individuais homogêneos. Direitos de mutuários em contratos de financiamento pelo SFH. Interesse coletivo configurado. Inafastável o caráter social do direito, assim constitucionalmente qualificado - art. $6^{\circ}$, CF. Não configurada a alegada violação aos artigos 127 e 129, III, CF. (...)"

2. Entendo, no entanto, razoável revogar a condenação da embargante ao pagamento de multa por litigância de má-fé. A interposição do 
agravo regimental não esteve fundada em abuso de prerrogativas processuais, mas apenas na tentativa legítima de reparar situação desfavorável à recorrente, a quem a dúvida a respeito favorece.

3. Tem razão, por fim, a embargante, ao apontar erro material constante da ementa do acórdão que apreciou o agravo regimental. A redação certa deve ser:

1. RECURSO. Extraondinário. Inadmissibilidade. Ministério Público. Legitimidade ativa. Ação civil públical. Sistema Financeiro da Habitação - SFH. Critério de reajuste do saldo devedor. TR. Jurisprudência assentada. Ausência de razões novas. Decisão mantida. Agravo regimental improvido. Nega-se provimento a agravo regimental tendente a impugnar, sem razões novas, decisão fundada em jurisprudência assente na Corte.

2. Recurso. Agravo. Regimental. Jurisprudência assentada sobre a matéria. Caráter meramente abusivo. Litigância de má-fé. Imposição de multa. Aplicação do art. $557, \mathbb{2 ^ { \circ }}$, cc. arts. 14 , II e III, e 17, VII, do CPC. Quando abusiva a interposição de agravo, manifestamente inadmissível ou infundado, deve o Tribunal condenar a agravante a pagar multa ao agravado.

4.

Do exposto, acolho, em parte, os embargos, para corrigir a redação da ementa, nos termos já expostos, e revogar a condenação da embargante por litigância de má-fé. Autorizo a embargante a levantar o depósito da multa.

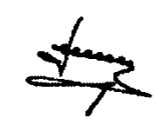

Ministro CEZAR PELUSO

Relator 
SEGUNDA TURMA

\section{EXTRATO DE ATA}

EMB.DECL.NO AG.REG.NO RECURSO EXTRAORDINÁRIO 470.135-9

PROCED.: MATO GROSSO

RELATOR : MIN. CEZAR PELUSO

EMBTE.(S): CAIXA ECONÔMICA FEDERAL - CEF

ADV. $(A / S)$ : EDUARDO ARRUDA ALVIM

ADV. (A/S): JOSÉ MANOEL DE ARRUDA ALVIM E OUTRO(A/S)

EMBDO. (A/S): MINISTÉRIO PÚBLICO FEDERAL

Decisão: A Turma, por votação unânime, acolheu, em parte, os embargos de declaraçāo, nos termos do voto do Relator. $2^{a}$ Turma, 22.05.2007.

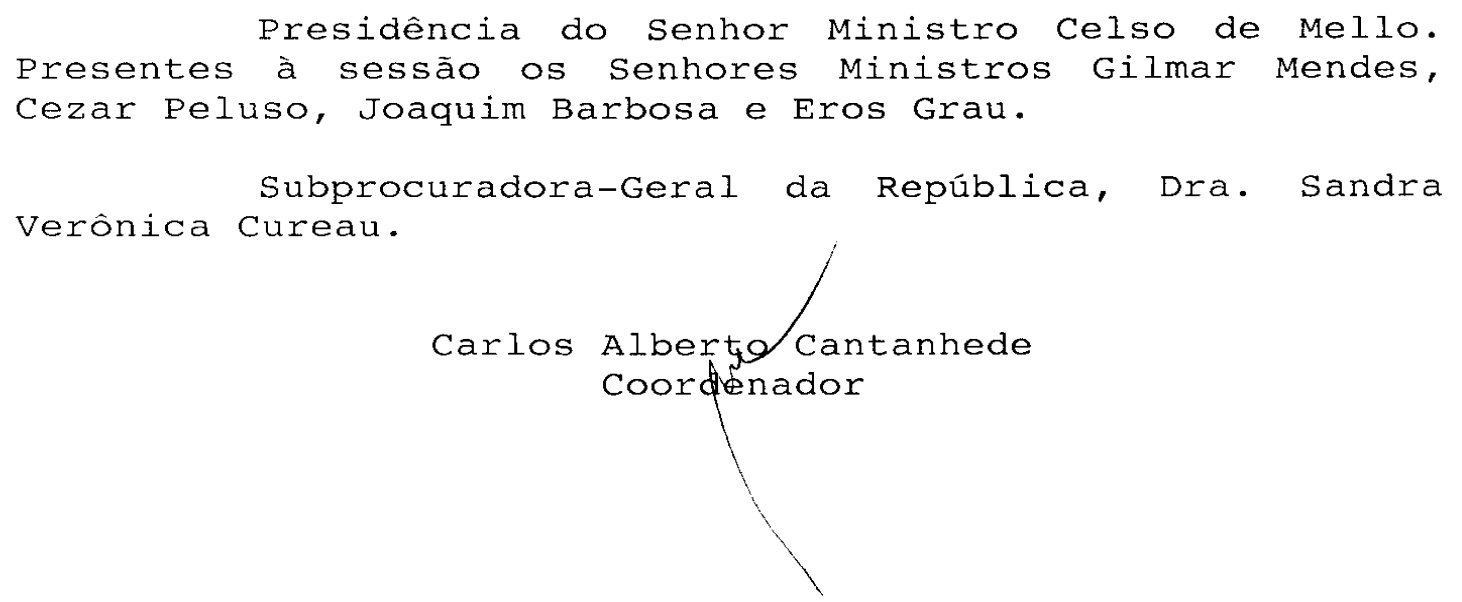


$03 / 09 / 97$

RECT
COORD. DE ANÁLISE DE JURISPRUDÊNCIA

D.J. 05.12.2003

EMENTÁRIO No 2135 - 1
TRIBUNAL PLENO $N^{\circ} 600-0 / 190-$ SÃO PAULO

\author{
RELATOR : MINISTRO NËRI DA SILVEIRA \\ RECLAMANTE: BANCO SUDAMERIS BRASII S/A \\ ADVOGADOS : ARNOLD WALD E OUTROS \\ RECLAMADO : PRIMEIRO TRIBUNAL DE ALÇADA CIVIL DO ESTADO DE SÃO \\ PAULO
}

mMenta: - Reclamação. 2. Ação civil pública contra instituição bancária, objetivando a condenação da ré ao pagamento da "diferença entre a inflação do mês de março de 1990, apurada pelo IBGE, e o Índice aplicado para crédito nas cadernetas de poupança, com vencimento entre 14 a 30 de abril de 1990, mais juros de $0,5 \%$ ao mês, correção sobre o saldo, devendo o valor a ser pago a cada um fixar-se em liqüidação de sentença". 3. Ação julgada procedente em ambas as instâncias, havendo sido interpostos recursos especial e extraordinário. 4. Reclamação em que se sustenta que o acórdão da Corte reclamada, ao manter a sentença, estabeleceu "uma inconstitucionalidade no plano nacional, em relação a alguns aspectos da Lei $n^{\circ}$ 8024/1990, que somente ao Supremo Tribunal Federal caberia decretar". 5. Não se trata de hipótese suscetível de confronto com o precedente da corte na Reclamação $n^{\circ}$ 434-1 - SP, onde se fazia inequívoco que o objetivo da ação civil pública era declarar a inconstitucionalidade da Lei $n^{\circ} 7.844 / 1992$, do Estado de São Paulo. 6. No caso concreto, diferentemente, a ação objetiva relação juridica decorrente de contrato expressamente identificado, a qual estaria sendo alcançada por norma legal subseqüente, cuja aplicação levaria a ferir direito subjetivo dos substituídos. 7. Na ação civil pública, ora em julgarnento, dá-se controle de constitucionalidade da Lei $n^{\circ} 8024 / 1990$, por via difusa. Mesmo admitindo que a decisão em exame afasta a incidência de lei que seria aplicável à hipótese concreta, por ferir direito adquirido e ato jurídico perfeito, certo está que o acórdão respectivo não fica imune ao controle do Supremo Tribunal F'ederal, desde logo, à vista do art. 102, III, letra ba, da Lei Maior, eis que decisão definitiva de Corte local terá reconhecido a inconstitucionalidade de lei federal, ao dirimir determinado conflito de interesses. Manifestase, dessa maneira, a convivência dos dois sistemas de controle de constitucionalidade: a mesma lei federal ou estadual poderá ter declarada sua invalidade, quer, em abstrato, na via concentrada, originariamente, pelo STF (CF, art. 102, I, a), quer na via difusa, incidenter tantum, ao ensejo do desate de controvérsia, na defesa de direitos subjetivos de partes interessadas, afastan

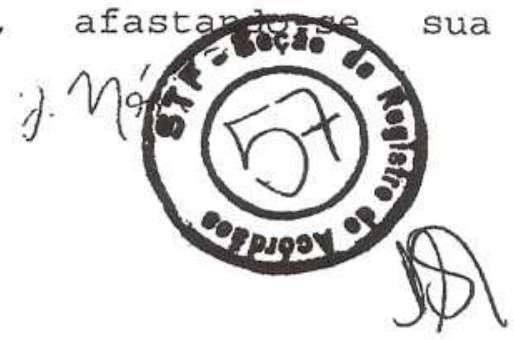


incidência no caso concreto em julgamento. 8. Nas ações coletivas, não se nega, à evidência, também, a possibilidade da declaração de inconstitucionalidade, incidenter tantum, de lei ou ato normativo federal ou local. 9. A eficácia erga omnes da decisão, na ação civil pública, ut art. 16, da Lei n 7347/1997, não subtrai o julgado do controle das instancias superiores, inclusive do STF. No caso concreto, por exemplo, já se interpôs recurso extraordinário, relativamente ao qual, em situações graves, é viável emprestar-se, ademais, efeito suspensivo. 10. Em reclamação, onde sustentada a usurpação, pela corte local, de competência do supremo Tribunal Federal, não cabe, em tese, discutir em torno da eficácia da sentença na ação civil pública (Lei n 7347/1985, art. 16), o que poderá, entretanto, constituir, eventualmente, tema do recurso extraordinário. 11. Reclamação julgada improcedente, cassando-se a liminar.

\section{A $C$ Ó $R$ R $\mathrm{D} \tilde{\mathrm{A}} \mathrm{O}$}

Vistos, relatados e discutidos estes autos, acordam os Ministros do supremo Tribunal Federal em sessão plenária, na conformidade da ata de julgamentos e das notas taquigráficas, por maioria de votos, julgar improcedente a reclamação, ficando sem efeito a medida liminar concedida.

Brasilia, 03 de setembro de 1997.
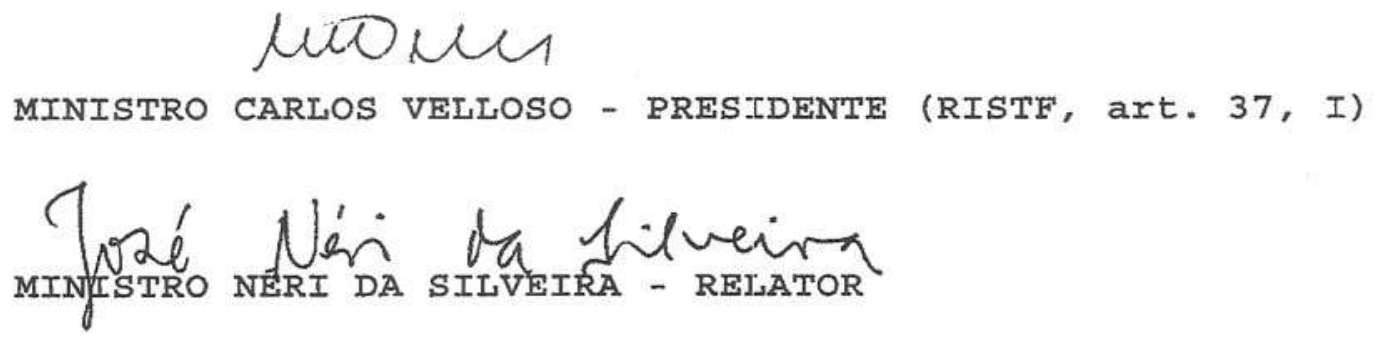


\title{
RECLAMACุÃO N. 600-0 SÃO PAULO
}

RELATOR : MIN. NÉRI DA SILVEIRA

RECLAMANTE: BANCO SUDAMERIS BRASIL S/A

ADVOGADO: ARNOLD WALD E OUTROS

RECLAMADO: PRIMEIRO TRIBUNAL DE ALCADA CIVIL DO ESTADO DE SAO PAULO

\author{
$\underline{R} \underline{E} \underline{\underline{A}} \underline{\underline{\underline{\sigma}}} \underline{\mathrm{R}} \underline{I} \underline{\mathrm{O}}$
}

O SENHOR MINISTRO NERI DA SILVEIRA - (Relator): - Cuida-se de Reclamação interposta pelo Banco Sudameris Brasil S.A. com base no art. 102, inciso I, letra "I" da Constituição Federal, artigos 13 e seguintes da Lei $n^{\circ} 8.038 / 90$ e artigos 156 e seguintes do Regimento Interno do Supremo Tribunal Federal, sendo reclamada a $5^{\circ}$ Câmra do Primeiro Tribunal de Alçada Civìl de são Paulo.

Apreciando pedido de liminar, assim sumariei a espécie:

"DESPACHO: - Vistos. O IDEC - Instituto Brasileiro de Defesa do Consumidor aforou, perante a $35^{\text {a }}$ Vara Cível da comarca de São Paulo, ação civil pública contra o Banco Sudameris Brasil S.A., "objetivando a condenação genérica do réu no pagamento da diferença entre a inflação do mês de março de 1990, apurada pelo IBGE, e 0 índice aplicado para crédito nas cadernetas de poupança, com vencimento em 14 a 30 de abril de 1990, mais juros de 0,5\% ao mês, correção sobre o saldo, devendo o valor a ser pago a cada um ser fixado em liqüidação de sentença" (Els. 70). A sentença deu pela procedência da ação "para condenar o réu a pagar aos seus aplicadores em poupança, com aniversário entre 14 e 30 (de abril de 1990) a diferença no mês de março (de 1990), entre o valor creditado e - Indice apontado pelo IBGE, mais juros de $0,5 \%$ ao mês, incidindo, depois, correção sobre a própria diferença e juros da citação. A liquaidação será feita por cál.culo do contador, na forma do CDC, arts. 95 a 100" (fls. 103). O Primeiro Tribunal de Alçada Civil do Estado de São Paulo, por sua Quinta Câmara, nos autos da Apelação $n^{\circ} 661.154-7$, em que recorrente o ora reclamante Banco Sudameris Brasil S.A. e apelado IDEC - Instituto Brasileiro de Defesa do Consumidor, unanimemente, negou provimento ao recurso, afirmando (fls. 118/119):

"A r. sentença, por ser procedente a demanda, fará coisa julgada exga omnes (art. 103, III, do CDC); portanto, irradiará os seus efeitos a todas as pessoas que ajustaram "conta poupança" com o réu até o dia 15.3 .90 , ras com datas de aniversário compreendidas na segunda

quinzena,

$$
\text { y Oiśn }
$$


independentemente de serem ou não associadas do autor e do local onde tenham sido celebrados os contratos (art. 103, III, parágrafo $3^{\circ}$, do CDC), uma vez que a jurisdição é uma só e abrange todo o território nacional.

Em outras palavras: não havendo limitação territorial para a eficácia da sentença transitada em julgado, a decisc̃o de primeiro grau - ora preservada - atingirát todos os poupadores, nas condições já referidas, que contrataram as contas em qualquer agência do réu, no território nacional."

No acórdão, em que rejeitados embargos de declaração do ora reclamante, o Tribunal reclamado anotou (fls 136): "A turma julgadora analisou a tese proposta nos autos: afastou a alegação de inépcia da inicial, de ilegitimidade passiva do banco privado e ativa do IDEC, de impropriedade da ação civil pública e, ainda, acolheu a ação com fundamento na infração ao princípio constitucional do direito adquirido derivado do ato jurídico perfeito (concretizado anteriormente à edição das normas que alteraram a forma de cálculo da correção monetária incidente sobre créditos em conta bancária)."

3. Foram interpostos recurso especial e recurso extraordinário (fls. $140 / 180$ e 183/222). Neste último, sustenta-se: "Evidenciada a violação pela decisão recorrida dos artigos $5^{\circ}, \mathrm{XXI}, \mathrm{XXXV}, \mathrm{XXXVI}$ e LV, 92, par. ún., 93, IX, 97, 102, I, "a", 125, $\$ 1^{\circ}$, e 129, $\$ 1^{\circ}$ da Constituição Federal e a declaração de inconstitucionalidade das normas do Plano Collor, requer seja admitido $\circ$ presente recurso e encaminhadas as anexas razões ao Egrégio Supremo Tribunal Federal, para os devidos fins de direito" (fls. 183).

Segundo a inicial, não há ainda decisão presidencial, na Corte reclamada, sobre a admissão do apelo extremo.

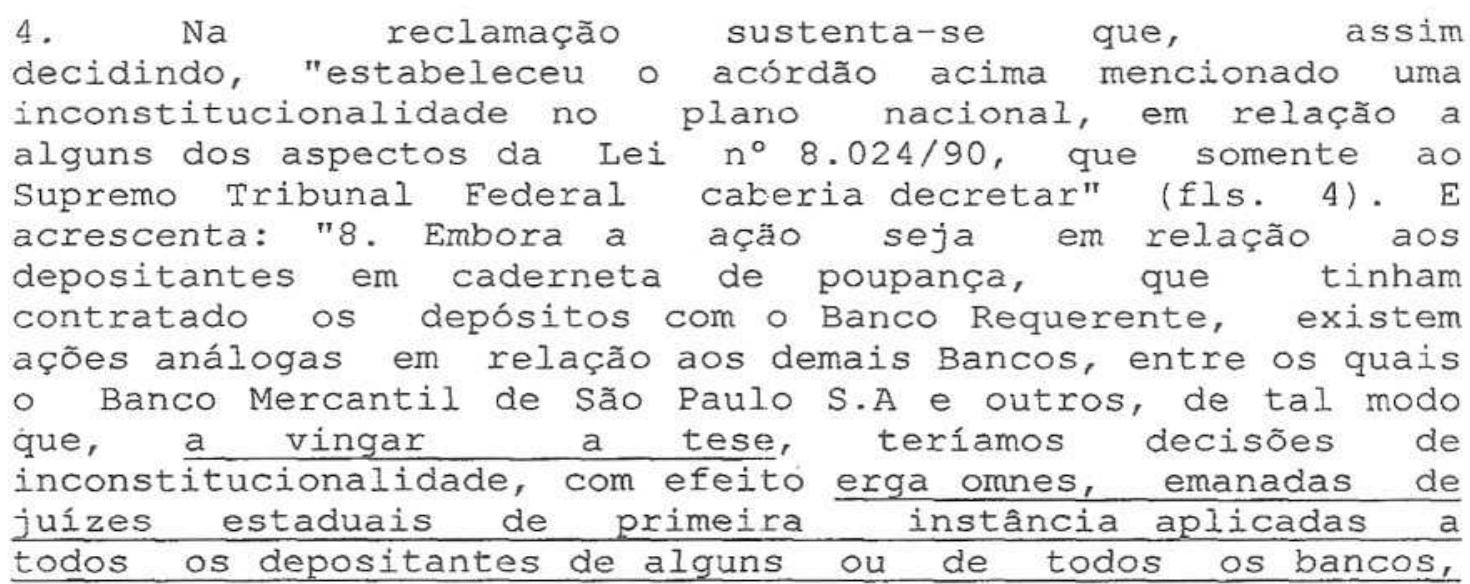


em todo o território nacional" (Els. 4).

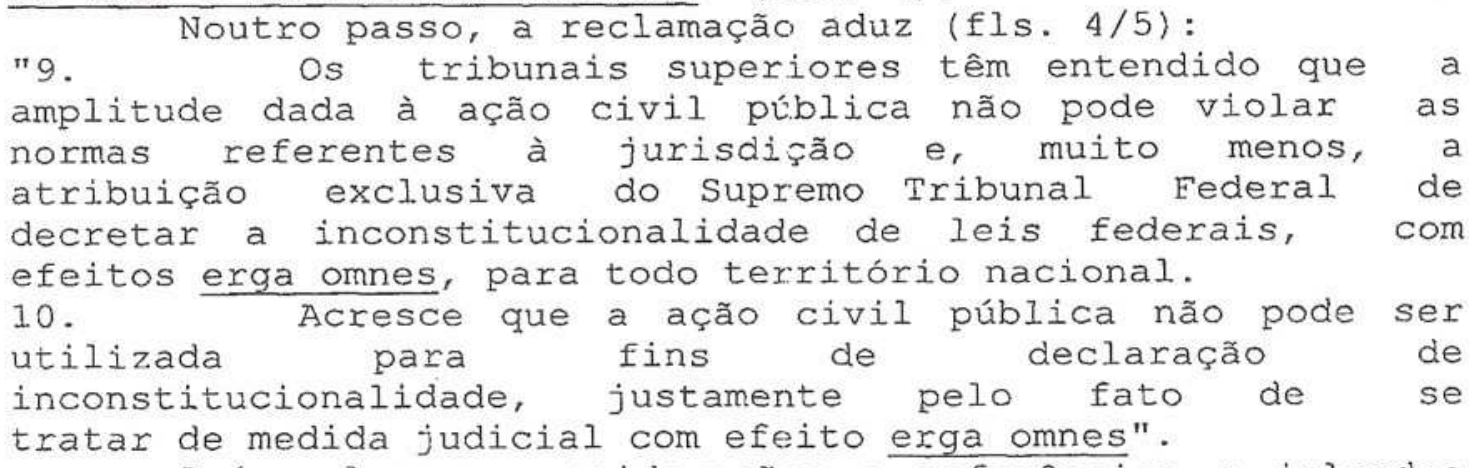
Após longas considerações e referências a julgados do STE e de outras cortes, o reclamente conclui, nestes termos (fls. 14/15):

"27. Sendo, pois, evidente que, pela sua própria natureza e pelo seu regime legal, não pode a ação civil pública ser utilizada como meio de declarar a inconstitucionalidade de disposições legais e que a competência na matéria é exclusiva do supremo Tribunal Eederal requer que, após a distribuição ao relator na forma regimental, seja ordenada a suspensão do processo referido (Lei $n^{\circ} 8.038 / 90$, a.rt. 14, II e artigo 158 do RISTF), requisitando-se as informações à autoridade reclamada, ouvindo-se o Ministério público e julgando-se procedente a Reclamação para o fim de cassar a decisão da $5^{a}$ Câmara do Primeiro Tribunal de Alçada Civil de são Paulo, no tocante à eficácia erga omnes da mesma, na forma do art. 17 da lei $n^{\circ} 8.038 / 90$ e do art. 161, III do RISTE, tudo de acordo com a jurisprudência deste Excelso pretório já firmada nas Reclamações $n^{\circ}$ 557-7, 559-3, 560-7, 562-3, 564-0 e 569-3 de Minas Gerais e 434-1 e 597-6 de São Paulo. A medida liminar é solicitada em virtude de ocorrer no caso tanto o fumus boni iuris decorrente da própria jurisprudência do Supremo Tribunal Federal, como também a existência de dano irreparável, caso seja executada a decisão em favor dos depositantes, e não havendo como em seguida voltar ao statu quo ante."

Entendendo serem relevantes os fundamentos da reclamação e que da execução imediata do acóxdão local em referência poderiam resultar danos irreparáveis ao reclamante, porque, nos termos do aresto, "a sentença, por ser procedente a demanda, fará coisa julgada erga omnes (art. 103, III, do CDC); portanto, irradiará os seus efeitos a todas as pessoas que ajustaram "conta poupança" com o réu até o dia 15.3.90, (...), uma vez que a jurisdição é uma só e abrange todo o território nacional" (fls. 118/119)-, deferi a medida liminar pleiteada, para suspender o processo referido, salvo quanto à apreciação pelo Presidente da corte reclamada do recurso extraordinário já interposto e seu eventual processamento, não cabendo, em 
conseqüencia, até o julgamento final da presente reclamação, qualquer execução do acórdão impugnado.

Informações requisitadas ao Primeiro Tribunal de Alçada Civil do Estado de São Paulo vieram aos autos com o ofício do Presidente daquela Corte (fls. 31.0/311), juntamente com os documentos que o acompanham (fls. 312/326), do qual destaco o seguinte trecho:

" O Instituto Brasileiro de Defesa do Consumidor - IDEC ajuizou ação civil pública contra $\circ$ Banco Sudameris Brasil $S / A$, visando compelir a entidade bancária a pagar aos seus aplicadores em cadernetas de poupança a diferença entre $\circ$ índice de correção monetária efetivamente creditado aos seus ativos financeiros e aquele incidente sobre os saldos existentes em março de 1990, conforme divulgado pelo IBGE.

Julgada procedente a demanda, apelou o Banco-vencido e a Egrégia Quinta Câmara deste Tribunal, por votação unânime, negou provimento ao recurso. Ficou consignado no v. acórdão que a procedência da ação fará coisa julgada "erga omnes", irradiando os seus efeitos a todos aqueles que ajustaram contas do tipo "poupança com o réu até 15 de maxço de 1990, mas com datas de aniversário compreendidas na segunda quizzena, "independentemente de serem ou não associados do autor e do local onde tenham sido celebrados os contratos (art. 103, III, parágrafo $3^{\circ},(C D C)$, uma vez que a jurisdição é uma só e abrange todo o território nacional".

Rejeitados os embargos de declaração apresentados, foram interpostos recurso extraordinário e recurso especial pelo ora reclamante, ora em processamento para posterior exame de admissibilidade por esta Presidencia.

Para melhor instruir o presente encaminho, nesta oportunidade, cópia reprográfica dos vv. acórdãos acima referidos."

Às fls. $334 / 344$ O IDEC - Instituto Brasileiro de Defesa do Consumidor, autor da Ação Civil Pública na qual se proferiu a decisão objeto desta reclamação, ofereceu impugnação concluindo que "os argumentos da Instituição Financeira - Reclamante são inconsistentes e denotam clara má-fé", uma vez que "através de instrumento jurídico incabível no caso em tela, e por meio de afirmação inverídica, pretende ver suspensa ação civil pública proposta pelo ora Requerente, desvirtuando a discussão trazida aos autos da referida demanda, que jamais tratou da constitucionalidade ou não da lei que instituiu o "Plano Verão", mas apenas do momento de sua incidencia, que não pode retroagir, ferindo o instituto constitucional do direito adquirido e do ato juridico perfeito".

Determinei comprovassem os signatários da Petição $\mathrm{n}^{\circ}$ 37.912-STE sua condição de procuradores do IDEC Instituto Brasileiro de Defesa do Consumidor, para postular o 
ingresso na Reclamação $n^{\circ} 600-0 / \mathrm{SP}$, o que foi devidamente satisfeito às fls. $394 / 395$.

- Reclamante Banco Sudameris Brasil S.A. contestou a impugnação oferecida pelo Instituto (fls. 380/391), asseverando que "a impugnação oposta pelo IDEC é totalmente desprovida de qualquer fundamento jurídico sério", e que, "embora o Tribunal paulista tenha deliberadamente evitado a expressa declaração de inconstitucionalidade dos dispositivos da Lei $n^{\circ} 8.024 / 90$, que deixou de aplicar, esta inconstitucionalidade foi reconhecida implicitamente, como deflui dos fundamentos da decisão, da causa petendi da inicial e do ordenamento processual brasileixo e ainda houve condenação para todo território nacional". Ressalta que "o que se discute é a preservação da competência deste Supremo Tribunal Federal, único órgão do Poder Judiciário pátrio autorizado na Carta Magna, a declarar a inconstitucionalidade de lei com efeito erga omnes, em todo o território nacional (CF, art. 102, I, "a").

A Procuradoria-Geral da República, em seu parecer de fls. 397/402, opinou pela procedência da presente reclamação.

É o relatório.

y-lión 
Presidente. Entendo que a Corte não está a julgar, aqui, a natureza da ação civil pública, nem se é constitucional, ou não, a eficácia erga omnes da sentença civil nessa demanda, em tese, prevista em disposição legal, bem assim não está decidindo sobre a possibilidade de extensão do decisum, além dos limites territoriais da jurisdição do magistrado ou tribunal que proferem julgado em demanda dessa natureza.

Se a norma legal federal que assim preceitua é ou não constitucional, não é matéria posta em exame na presente reclamação. Em reclamação contra decisão em caso concreto, em que se alega usurpação da competência da Corte, não hầ o Supremo Tribunal Federal de examinar, em tese, a natureza da ação civil pública e da eficácia das disposições que a regem. Para isso, há lugar próprio: em ação direta de inconstitucionalidade, ou mesmo, incidenter tantum, em julgamento de recurso contra decisão em ação civil pública.

É a observação inicial que Éaço, passando a proferix o voto sobre a reclamação.

$$
\text { Q. } \operatorname{los}
$$


Siuproma Eribunal OFederal.

O SENHOR MINISTRO NÉRI DA SILVEIRA (RELATOR):

Conforme se verifica do acórdão, objeto da reclamação, às fls. 110/120, a ação civil pública foi aforada, "por ofensa a interesse difuso ou coletivo, consistente na conduta do réu em não creditar aos titulares de contas do tipo poupança a diferença de correção monetária alusiva ao indice inflacionário de março/9o" (fls. 111).

Noutro passo, assere (fls. 112/115):

"A hipótese, na verdade, apresenta todas as características de ação coletiva para a defesa de interesses individuais homogêneos (arts. 91/100 do Código de Proteção e Defesa do Consumidor).

Tanto é assim que a própria petição inicial fez alusão ao assunto (fls. $32 \mathrm{e} 39$ ), não obstante o rótulo diverso da ação.

PONTES DE MIRANDA ensinava: "A conversão da pretensão, ou da ação, é de direito material. A respeito só existe, no direito processual brasileiro, o princípio de não ser necessário nomear-se a ação. 0 erro de nome da ação não importa, é irrelevante. Esse principio, também chamado de irrelevância do nome da ação, é velho no direito luso-brasileiro. Idem, quanto ao remédio jurídico processual" ('Comentários', tomo III, pág. 351, Forense, 1.974).

Ademais, doutrina e jurisprudência, dobrandose à necessidade de atender às exigências da economia processual, admitem, sem rebuços, que a denominação errônea da ação não induz a sua nulidade, cumprindo, antes, ao juiz verificar se, ra espécie, concorrem os requisitos de uma outra ação que não a designada. No caso, apesar daquele rótulo, a ação é coletiva, pois objetiva a reparação dos danos pessoalmente sofridos pelos consumidores, enquanto os depósitos bancários ensejam relações de consumo, fonte de tal demanda.

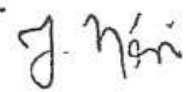


- Código de Defesa do Consumidor trata abrangentemente da matéria sobre as relações de consumo e não se limita a regulamentar e prever sanções administrativas e penais. Oferece medidas específicas, em busca da equiparação entre as paxtes na relação juxídica de consumo; esta, sabidamente, é desigual, pois o fornecedor é economicamente mais forte, enquanto o consumidor é o hipossuficiente econômico.

- código tem como filosofia básica dar um plus ao consumidor, para igualá-1o, nas relações de consumo, ao fornecedor.

Essa finalidade visa equilibrar fornecedores e consumidores, sem que haja preponderância da parte mais forte; protege-se, assim, a parte mais fraca e suscetível de ser Iesada; daí o art. $4^{\circ}$, inciso $I$, do Código de Defesa do Consumidor reconhecer a vulnerabilidade do consumidor no mercado de consumo.

É irrecusável que o aplicador em cadernetas de poupança mantidas por instituições financeiras, diante de tais princípios, é a parte vulnerável na relação, daí - enquadramento dos depósitos bancários no objeto do Código de Defesa do Consumidor, visto não serem estranhos ao conceito de consumo.

Por outro lado, a legitimidade do autor para propor ações deste jaez é indiscutível em face dos arts. 81 e 91 do Código de Proteção e Defesa do Consumidor.

Trata-se, pois, de ação civil coletiva de responsabilidade pelos danos individualmente sofridos, até porque observou-se o seu rito específico com a expedição do edital de fls. 135 e 139 (art. 94), impondose, outrossim, a participação do Ministério público até os ulteriores termos do processo (art. 92).

Este Tribunal, em inúmeros julgados versando sobre a matéria ora debatida, deixou assentado que o poupador deve exigir do banco receptor o cumprimento da obrigação, pois com este celebrou o contrato; logo, o réu é parte legítima para figurar no pólo passivo da lide, não se vislumbrando qualquer interesse juríico da União ou do Banco Central; tampouco se justifica o deslocamento da competência para a Justiça Federal, eis que o pagamento da correção monetaria resulta de obrigação assumida por instituição financeira privada.

Ficam, com tais fundamentos, rejeitadas as preliminares argüidas no recurso, alusivas à inépcia da inicial, ilegitimidade ativa do IDEC e passiva do apelante, legitimidade ativa exclusiva do Ministério público e impropriedade da ação civil pública." 
Examinando, a seguir, o mérito da causa, o acórdão assim se fundamentou (fls. 115/120), verbis:

"3. A caderneta de poupança é um meio utilizado pelo poupador para preservar valores em face da inflação, tanto que ao valor da inflação é acrescida a taxa de $0,5 \%$ de juros ao mês, sem qualquer outra forma de remuneração, envolvendo risco típico dos verdadeiros negócios de aplicação.

Resulta daí que o poupador tem o direito de receber a correção monetária equivalente à inflação real do período em que subsistiu o depósito, sendo incabível a teoria da imprevisão, pois vive-se num país inflacionado, de longa data convertido em laboratóxio de experiências, cujas soluções têm sido desastrosas.

Ademais, vem esta Câmara entendendo que a caderneta de poupança é um contrato de adesão entre o poupador e o estabelecimento bancário, constituindo-se em ato jurídico perfeito e acabado, inadmissivel qualquer alteração unilateral em suas regras.

0 art. 17, III, da Lei $7.730 / 89$ estabelecia que os saldos das cadernetas de poupança seriam atualizados com base na variaçăo do IPC do mês anterior e essa regra foi alterada pela Lei 8.024/90.

Permitix-se que legislação posterior atinja aquela avença constitui violação ao princípio do ato jurídico perfeito, por dispor sobre a aplicação às cadernetas de poupança de índices menores do que aqueles apurados pelo IBGE para O IPC.

Daí porque a legislação casuística - editada em malograda tentativa para fulminar a inflação perturbou o direito adquirido dos poupadores (art. 5\%, $X X X V I$, da $C F$ ).

Aliás, o Colendo Supremo Tribunal Federal consagrou o respeito a esse princípio, mesmo sendo de ordem publica ou econômica a norma que os afxonta (STF Pleno; $A D I N$ n 493-0-DF, rel. Min. Moreira Alves, j. 256-92; DUU, 04-9-92, p. 14.089. Seção I, ementa - Boletim AASP $\left.n^{\circ} 1.762\right)$.

Por outro lado, como bem destacou o Juiz MAURICIO VIDIGAI, "a correção monetária é simples atualização de valores. É natural que os gestores de politicas econômicas tentem, com o objetivo de combater a inflação, mascarar a perda do valor da moeda, editando indices que não correspondam à realidade. Tais atos atendem à conveniência do momento, não contendo a intenção de distribuir justiça, mas a de solucionar questões econômico-financeiras. O juiz, porém, encarregado de ordenar a atualização justa, não pode deixar de considerar a real perda do valor da moeda, se pretende a justiça. E não há lei que o 
impeça de assim agir, porque o espírito, tanto da criação pretoriana que autorizou correção monetária de alguns débitos, quanto da lei que generalizou seu uso, contém a intenção de que as relaçôes entre credores e devedores não sejam desequilibradas pela desvalorização da moeda, devendo ser mantidas semelhantes com a atualização real" (A. I. $n^{\circ}$ 497.923/1, desta Câmara, j. 25-3-92).

Acresce notar que a adoção de Indice que não reflita a inflação real de determinado período, ainda que oficial, enseja a revisão pelo poder Judiciário, pois redundaria em enriquecimento sem causa do estabelecimento bancário (apelação $n^{\circ}$ 525.3.20-3, desta Câmara, $j$. 26.5.93).

Nem o bloqueio das contas pelo Banco Central pode dispensar o réu de creditar a correção monetária reclamada pelos poupadores em face do que dispõem os arts. 1.266 e 1.256 do Código Civil.

Outrossim, não há prova nos autos de que o bloqueio determinado pelo governo federal acarretou a transferência real de dinheiro para o Banco Central. e mesmo que houvesse essa passagem de valores, o réu responderia pelos prejuízos dos aplicadores, ante o xisco assumido com o contrato de poupança e previamente conhecido.

o conhecimento desse risco impede, no regime intervencionista brasileiro, a inovação do fato do príncipe como desculpa para o inadimplemento contratual, como bem enfatizou o Juiz SEINA REBOUÇAS: "... banqueiros $e$ homens de negócio que emprestam dinheiro ou tomam-no emprestado, sabem perfeitamente onde pisam, com o que reduzem a margem de erro, posto subsista ela em qualquer tipo de negócio, em qualquer mercado. 0 risco do negócio é sempre um ponto mínimo no rol das possibilidades. Mas, por minimo que seja, ele existe! É circunstância considerada em todo contrato (explícita ou implicitamente)..." (RT 673/97).

Aliás, o mesmo relator, em outro recurso, analisou o tema em pauta e assim se expressou: "... o fato do príncipe está relacionado mais adequadamente com a execução de um contrato administrativo stricto-sensu, execução que é impedida por fato do Estado, imprevisto e imprevisivel, cujo grau de intolerabilidade obriga o Poder Público a compensar ou indenizar, ou rende ensejo à rescisão do contrato com as indenizações cabiveis..." (Apelação $n^{\circ}$ 524.179-9 2* Camara, j. 10.3.93; Bol. AASP 1797/220).

4. Fica, com as observações já apontadas, mantido o r. julgado de primeiro grau.

A r. sentença, por ser procedente a demanda, fará coisa julgada erga omnes (art. 103, III, do $C D C)$; portanto, irradiará os seus efeitos a todas as pessoas que ajustaram conta poupança com o réu até o dia 


\section{西}

15-3-90, mas com datas de aniversário compreendidas na segunda quinzena, independentemente de serem ou não associadas do autor e do local onde tenham sido celebrados os contratos (art. I03, III, paragrafo $3^{\circ}$, do $(D C)$, uma vez que a jurisdição é uma só e abrange todo o território nacional.

Em outras palavras: não havendo Iimitação territorial para a eficácia da sentença transitada em julgado, a decisão de primeiro grau - ora preservada atingirá todos os poupadores, ras condições já referidas, que contrataram as contas em qualquer agência do réu, no território nacional.

Quanto à execução resta assinalar que os sistemas processuais do CDC e da LACP são interligados, sendo aplicáveis indistintamente um ao outro reciprocamente, conforme determinam os arts. 90 do $C D C$ e 21 da LACP.

Tais diplomas estabelecem duas fases distintas na ação coletiva: a primeira refere-se ao processo de conhecimento, que é promovido pelos entes legitimados pelo art. 82 do $C D C$ e que se finaliza com o trânsito em julgado da sentença condenatória que estabelece o direito à indenização e a segunda terá início com a habilitação daqueles que tiveram seus direitos pelo ente que promoveu a ação, para a liquidação e execução da sentença conderatória, que será promovida pelos habilitados (art. 98 do CDC).

POSTO ISSO, a turma julgadora nega provimento ao recurso, com observação."

Precisaram-se a inteligência dc aresto e seus limites, no acórdão referente ao julgamento de embargos de declaração (fls. 136):

"A turma julgadora analisou a tese proposta nos autos: afastou a alegação de inépcia da inicial, de ilegitimidade passiva do banco privado e ativa do IDEC, de impropriedade da ação civil pública e, ainda, acolheu a ação com fundamento na infração ao principio constitucional do direito adquirido derivado do ato jurídico perfeito (concretizado anteriormente à edição das normas que alteraram a forma de cálculo da correção monetária incidente sobre créditos em conta bancária)."

Dessa decisão local interpuseram-se recurso especial (fls. $140 / 180$ ) e recurso extraordinário (fls. 183/222).

Desde logo, cumpre notar que não se trata, aqui, de hipótese suscetível de confronto com o precedente da corte na 5 y. Var 
Reclamação no 434-1-SP (fls. 238/257). Nesta, restou claro o objetivo das ações ajuizadas "a declarar de inconstitucionalidade da Lei $n^{\circ} 7.844$, de 13 de maio de 1992, do Estado de São Paulo, e do Decreto $\Omega^{\circ} 35.606$, de 3 de setembro de 1.992 , que a regulamentou" (fls. 238). No voto, à sua vez, observou o ilustre Ministro Francisco Rezek (fls. 250/251):

"No caso em analise, não indicaram as empresas autoras um conflito de interesses que sirva de cenário ao juízo incidental de constitucionalidade. Menos ainda se entende a razão de figurar no pólo passivo da ação ordinária a Fazenda do Estado de São Paulo. Esta não tem, na hipótese, Iitígio a ser resolvido. Não praticou ato algum baseado na lei. Não tem relação com a norma, votada na Assembléia Legislativa e chancelada pelo Governador; e muito menos com sua execução, posto que não é responsável por sua aplicação, nada implementa, nada fiscaliza, nada sanciona. Não possui, desse modo, legitimidade passiva para a ação. Como observou o advogado da União Nacional dos Estudantes (UNE), a Fazenda do Estado figura com ré "unicamente, porque era preciso haver parte contrária para a ação de cognição, embora a lide não tenha objeto contra o demandado, posto que o pedido dirige-se contra a lei em tese, consumada, assim e sem a menor sombra de dúvida, a usurpação da competência concentrada do (...) Supremo Tribunal Federal." (fIs. I5).

Desta forma, não se configura nenhum litígio, nenhum caso concreto que sirva de base à declaração incidental de inconstitucionalidade pela competência difusa do juiz de primeiro grau. Resulta claro que o controle direto de constitucionalidade foi repassado ao juizo monocrático estadual, em óbvia usurpação da competência concentrada desta casa.

observara-se, na representação encaminhada à Procuradoria-Geral da República, que é impressionante "a insensibilidade geral para com a competência do Supremo Tribunal Federal. Todos discutem a possibilidade ou não de prejuizos aos cinemas com a venda da meia entrada, isto é, discutern o possivel acerto ou desacerto da lei, mas não se firmam, não debatem, nem sequer contestam a competência do Supremo Tribunal Federal para a declaração de inconstitucionalidade, em tese, da lei estadual. Os processos tramitam com a maior naturalidade, como se não existisse o comando constitucional e as alegações da Fazenda do Estado de São Paulo, a este respeito, não são sequer rebatidas." (fIs. 13).

Tenho, afinal, como evidenciado que as ações em curso não visam ao julgamento de uma relação jurídica concreta, mas ao da validade da lei em tese, de competência exclusiva do supremo Tribunal Federal, nos termos do artigo 102, I, a, da Carta da República."

6

$$
\text { ग. Mर́r }
$$


Diversa se entremostra a situação das partes no caso concreto, onde se objetiva relação jurídica decorrente de contrato expressamente identificado e que estaria sendo alcançada por norma legal subseqüente, cuja aplicação levaria a ferir direito subjetivo dos substituídos. É hipótese típica de controle difuso de constitucionaliade. As instâncias ordinárias deixam de aplicar, ao caso concreto, a lei por entender que ela causa lesão ao ato jurídico perfeito e ao direito adquirido. Não se trata de ação declaratória de invalidade, em tese, de uma lei, desvinculadamente de qualquer cogitação quanto à sua incidêrıcia em determinada relação jurídica em que se evidenciam situações subjetivas.

Se a solução dada pelo acórdão está correta ou não, dirão as instâncias superiores, no julgamento dos recursos, de índole extraordinária já interpostos e a respeito dos quais poderá, à evidência, o ora reclamante pleitear o efeito suspensivo do recurso, para que a eficácia da decisão local não se opere antes da final decisão do supremo Tribunal Federal. Aqui, ademais, haverá espaço ao longo debate sobre a ação civil püblica, como intentada, e ainda nos limites de sua eficácia que a lei clausula de erga omnes.

Si et in quantum, não hâ falar em usurpação de competência do STF, - reparável, destarte, enquanto se processam recursos adequados, inclusive, a esta Corte, por via de reclamação.

De fato, não tenho, desde logo, como possível acolher a assertiva segundo a qual a ação civil pública, na espécie, implique usurpação da competência do supremo Tribunal Federal, prevista no art. 102, I, letra a, da Constituição.

Na ação civil pública ern exame, dā-se controle de constitucionalidade da Lei $n^{\circ} 8024 / 9 \mathrm{C}$, por via difusa. Mesmo admitindo que a decisão nas vias ordinárias afasta a incidência de lei aplicável à hipótese concreta, ao entendimento de sua não aplicação, por ferir direito adquirido e ato juridico perfeito, decerto, o acórdão não fica imune ao controle do supremo Tribunal Federal, desde logo, à vista do art. 102, III, letra $\underline{b}$, da Lei Maior, eis que a decisão definitiva da corte local terá reconhecido a inconstitucionalidade de lei federal. A quaestio juris virá, então, ou isso poderá sucedê-Io, ao controle desta Corte. Tal, de resto, ocorre no mecanismo do controle difuso de constitucionalidade de lei federal ou local.

Nessa linha, convivem os dois sistemas de controle de constitucionalidade: a mesma lei federal ou estadual poderá ter declarada sua invalidade, quer, em abstrato, na via concentrada, originariamente, nesta corte, quer na via difusa, incidenter tantum, no desate de controvérsia, na defesa dos direitos subjetivos das partes interessadas, afastando-se sua incidência no caso concreto em julgamento. Nas ações coletivas, não se afasta, à evidência, a

$$
\text { c.j. nari }
$$




\section{RECLAMAÇÃO

possibilidade da declaração de inconstitucionalidade, incidenter tantum, de lei ou ato normativo federal ou local.

Ganha, é certo, espaço especial a consideração da matéria, quando a decisão, na ação civil pública, tem eficácia erga omnes, à semelhança do que sucede com o acórdão na ação direta de inconstitucionalidade de lei ou ato normativo federal ou estadual, bem assim na ação declaratória de constitucionalidade de lei ou ato normativo federal.

De fato, no controle difuso, a declaração de inconstitucionalidade incidenter tantum pelo STF opera entre as partes litigantes, somente se tornando a decisão, com eficácia erga omnes, na hipótese de o Senado Federal, recebendo a comunicação do STF, quanto à decisão definitiva, suspender a execução no todo ou em parte, da lei declarada inconstitucional por esta corte (Constituição, art. $52, \mathrm{X}$ ).

$\mathrm{Na}$ ação civil pública, a decisão opera erga omnes; o autor não defende direito subjetivo próprio, mas um interesse público devidamente caracterizado. Não tenho, entretanto, como possível desde logo, ver, na ação civil pública, um processo objetivo, à semelhança do que sucede com a ação direta de inconstitucionalidade ou a ação declaratória de constitucionalidade, segundo a jurisprudência desta corte.

Certo está, de outra parte, que a lei, de explícito, estipula, na ação civil pública, que "a sentença civil fará coisa julgada erga omnes", bem assim dá-se, aí, a extensão da jurisdição.

A eficácia erga omnes da decisão está prevista na lei $n^{\circ}$ 7347, de 24.7.1985, art. 16, verbis:

"A sentença civil fará coisa julgada erga omnes, exceto se a ação foi julgada improcedente por deficiência de provas, hipótese em que qualquer legitimado poderá intentar outra ação com idêntico fundamento, valendo-se de nova prova."

Como antes anotei, não se subtrai ao controle das instâncias superiores a decisão em ação civil pública, inclusive desta Corte. No caso concreto, por exemplo, já se interpôs recurso extraordinário. Ora, se assim é, cabendo, em matéria grave, emprestar-se efeito suspensivo ao recurso extraordinário, cumpre entender que a eficácia erga omnes da sentença, na ação civil, inclusive e notadamente quando nela se faz, incidenter tantum, declaração de inconstitucionalidade de lei federal ou estadual, a rigor não sucederá, antes do definitivo pronunciamento do Supremo Tribunal Federal.

Cuida-se de declaração de inconstitucionalidade de lei, incidenter tantum, no bojo de ação civil pública, por sentença que poderá vir ao exame do Supremo Tribunal F'ederal. 
Não cabe, de outra parte, de qualquer sorte, nesta reclamação, discutir sobre a cláusula erga omnes da eficácia da sentença civil na ação civil pública, prevista no art. 16, da Lei nº 7347/1985, o que, à evidência, se for objeto do debate, no recurso extraordinário, neste, terá a via apropriaća, para a apreciação da valia dessa norma.

Do exposto, não vendo nos termos em que posta a controvérsia deduzida na reclamação, diante do que assentou o acórdão, usurpação da competência do supremo Tribunal Federal, com base no art. 102, I, I, da Constituição, julgo improcedente esta reclamação e casso a liminar.

Se o mérito da demanda procede, ou não, se está correto ou não o acórdão, se a ação civil pública cabia ou não para a discussão da controvérsia - tudo isso poderá ainda vir a ser apreciado ao ensejo do julgamento do recurso extraordinario já interposto e a respeito do qual é admissível, inclusive, em situações especiais e relevantes, deferir-se efeito suspensivo.

$$
\lambda \cdot \operatorname{lng}
$$




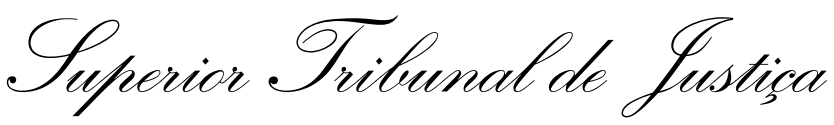

RECURSO ESPECIAL N ${ }^{0}$ 411.529 - SP (2002/0014785-9)

$\begin{array}{ll}\text { RELATORA } & \text { : MINISTRA NANCY ANDRIGHI } \\ \text { RECORRENTE } & : \text { INSTITUTO BRASILEIRO DE DEFESA DO CONSUMIDOR IDEC } \\ \text { ADVOGADOS } & : \text { DULCE SOARES PONTES LIMA } \\ & \text { ANDRÉA LAZZARINI } \\ & \text { DAIRSON MENDES DE SOUZA E OUTRO(S) } \\ \text { RECORRIDO } & : \text { BANCO BANESTADO S/A } \\ \text { ADVOGADOS } & : \text { RAUL QUEIROZ NEVES } \\ & \text { LUIZ RODRIGUES WAMBIER E OUTRO } \\ & \text { GUILHERME PIMENTA DA VEIGA NEVES E OUTRO(S) }\end{array}$

EMENTA

Processo civil e direito do consumidor. Ação civil pública. Correção monetária dos expurgos inflacionários nas cardenetas de poupança. Ação proposta por entidade com abrangência nacional, discutindo direitos individuais homogênios. Eficácia da sentença. Ausência de limitação. Distinção entre os conceitos de eficácia da sentença e de coisa julgada. Recurso especial provido.

- A Lei da Ação Civil Pública, originariamente, foi criada para regular a defesa em juizo de direitos difusos e coletivos. A figura dos direitos individuais homogênios surgiu a partir do Código de Defesa do Consumidor, como uma terceira categoria equiparada aos primeiros, porém ontologicamente diversa.

- A distinção, defendida inicialmente por Liebman, entre os conceitos de eficácia e de autoridade da sentença, torna inóqua a limitação territorial dos efeitos da coisa julgada estabelecida pelo art. 16 da LAP. A coisa julgada é meramente a imutabilidade dos efeitos da sentença. Mesmo limitada aquela, os efeitos da sentença produzem-se erga omnes, para além dos limites da competência territorial do órgão julgador.

- O procedimento regulado pela Ação Civil Pública pode ser utilizado para a defesa dos direitos do consumidor em juizo, porém somente no que não contrariar as regras do $C D C$, que contem, em seu art. 103, uma disciplina exaustiva para regular a produção de efeitos pela sentença que decide uma relação de consumo. Assim, não é possível a aplicação do art. 16 da LAP para essas hipóteses.

Recurso especial conhecido e provido.

\section{ACÓRD̃̃o}

Vistos, relatados e discutidos estes autos, acordam os Ministros da TERCEIRA TURMA do Superior Tribunal de Justiça, na conformidade dos votos e das notas taquigráficas constantes dos autos, prosseguindo no julgamento, após o voto-vista do Sr. Ministro Sidnei Beneti, conhecendo do recurso especial e dando-lhe provimento, por maioria, conhecer do recurso especial e dar-lhe provimento. Vencidos os Srs. Ministros Humberto Gomes de Barros e Ari Pargendler. Votaram com a Sra. Ministra Relatora o Sr. Ministro Castro Filho e o Sr. Ministro Sidnei Beneti. 


\section{Suporior Fribunal de fustica}

Brasília (DF), 24 de junho de 2008.(data do julgamento).

\section{MINISTRA NANCY ANDRIGHI \\ Relatora}

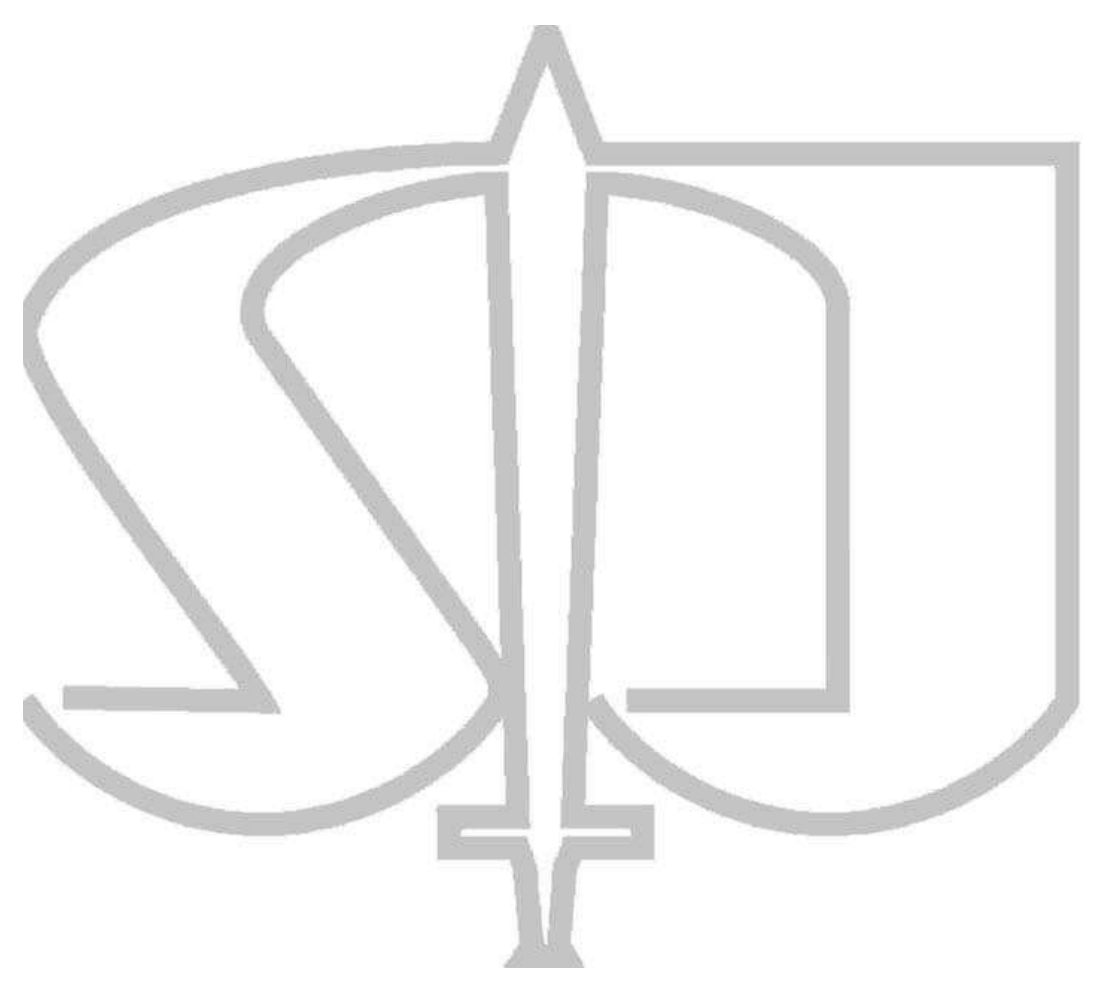




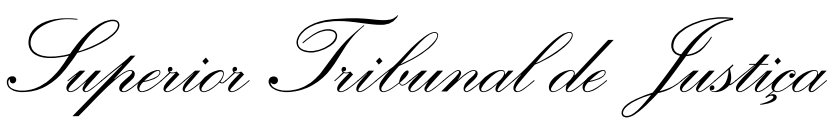

RECURSO ESPECIAL No 411.529 - SP (2002/0014785-9)

\section{RELATÓRIO}

\section{A EXMA. SRA. MINISTRA NANCY ANDRIGHI (Relator):}

Cuida-se do recurso especial interposto por INSTITUTO BRASILEIRO DE DEFESA DO CONSUMIDOR - IDEC , fundamentado nas alíneas "a" e "c" do permissivo constitucional, contra acórdão do TAC/SP.

Ação: A entidade autora moveu Ação Civil Pública por danos provocados a interesses individuais homogêneos em face do antigo Banco do Estado do Paraná, o Banestado. Reclamou, como direito, fosse a Instituição Financeira condenada a ressarcir a diferença de rendimento apurado e creditado a menor nas cadernetas de poupança em janeiro de 1989.

Sentença: o Juiz a quo proferiu sentença de procedência, condenando o Banco ao pagamento da diferença de 48,16\% aplicável ao saldo existente em janeiro de 1989. Os efeitos da decisão, contudo, foram restringidos aos limites da jurisdição daquele juízo, nos seguintes termos:

"Poderão os poupadores que firmaram contrato com o réu, em agência localizada nesta Capital e que aqui mantêm domicílio, pleitearem a execução do julgado nestes mesmos autos."

Recurso de apelação: interposto pelo réu, visando a modificação integral da sentença.

Recurso adesivo: interposto pela Associação, propugnando pela reforma da sentença na parte que restringiu os efeitos da decisão aos limites da jurisdição do órgão prolator.

Parecer do Ministério Público do Estado de São Paulo: opinou pelo provimento do recurso adesivo, posto, entender aplicável à espécie o art. 103, III do CDC.

$1^{0}$ Acórdão: O TJSP anulou, de ofício, a sentença, determinando a remessa dos autos ao Foro do Distrito Federal, prejudicando o exame dos recursos. Eis a ementa: 


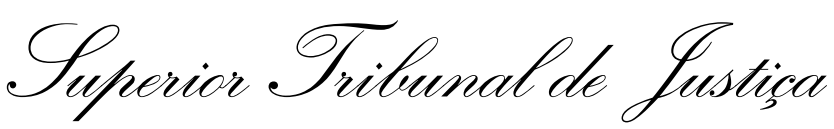

Competência - ação civil pública - caderneta de poupança diferença de rendimentos - direitos individuais homogêneos - dano de âmbito nacional - incompetência absoluta - sentença anulada de ofício remessa dos autos ao foro do distrito federal

Remetidos os autos ao TJDF, este suscitou conflito de competência. Apreciando a questão, esta Terceira Turma do Superior Tribunal de Justiça houve por bem determinar a competência do Tribunal paulista para decidir a lide, por acórdão assim ementado:

"Conflito de competência. Ação Civil Pública. Código de Defesa do Consumidor.

1. Interpretando o artigo 93, inciso II, do Código de Defesa do Consumidor, já se manifestou esta Corte no sentido de que não há exclusividade do foro do Distrito Federal para o julgamento de ação civil pública de âmbito nacional. Isto porque o referido artigo, ao se referir à Capital do Estado e ao Distrito Federal invoca competências territoriais concorrentes, devendo ser analisada a questão estando a Capital do Estado e o Distrito Federal em planos iguais, sem conotação especifica para o Distrito Federal.

2. Conflito conhecido para declarar a competência do Primeiro Tribunal de Alçada Civil do Estado de São Paulo para prosseguir no julgamento do feito."

$\mathbf{2}^{\circ}$ Acórdão: Com a referida decisão, os autos foram novamente remetidos ao TAC/SP, que deu parcial provimento ao recurso, em acórdão assim ementado, na parte que interessa para os fins deste recurso especial:

"Contrato bancário - caderneta de poupança - relação de consumo - artigo 30, caput e $\S 2^{\circ}$ do código de defesa do consumidor

(...)

Ação Civil Pública - efeitos da decisão - limitação à competência do órgão prolator - artigo 16 da lei $n .7 .734 / 85$, com a redação dada pela lei n. 9.494/97 - recurso adesivo não provido"

Recurso especial: o IDEC alegou violação ao art. 103, III, do CDC e divergência jurisprudencial no ponto que trata dos efeitos da sentença que julgou a ação civil pública. Assegurou, citando ADA PELLEGRINI, que: 


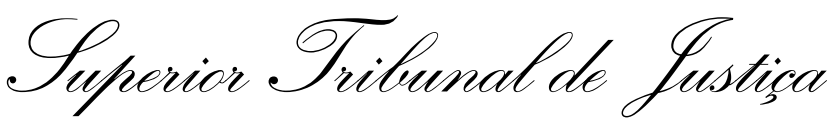

"a questão não é de jurisdição, ou de competência, mas de limites subjetivos, ou efeitos, da coisa julgada... Não se trata, no caso, de estender a competência, que será rigorosamente observada. O fato é que a sentença proferida pelo Juiz Federal de São Paulo, no âmbito de sua competência constitucional, atingirá, com sua autoridade, todas as pessoas que se encontrem na mesma situação, independentemente do local de seu domicílio."

Parecer do Ministério Público Estadual: favorável ao provimento do especial. Com apoio na doutrina de KAZUO WATANABE, atesta não haver sentido admitir-se uma segunda demanda para a tutela dos interesses coletivos lato sensu (inclusos os individuais homogêneos), "mormente se veiculados por um ente legitimado para todo o País... De pronto é constatável a ocorrência da litispendência."

Parecer do Ministério Público Federal: desfavorável ao provimento do especial, nos termos da seguinte ementa:

"RECURSO ESPECIAL. AÇÃO CIVIL PÚBLICA. REAJUSTE DE RENDIMENTO DE CADERNETA DE POUPANÇA. DIREITO INDIVIDUAL HOMOGENNEO. RELAÇÃO DE CONSUMO. COISA JULGADA ERGA OMNES. APLICAÇÃO DO ART. 16 DA LEI 7.347/85 (REDAÇÃO DADA PELA LEI 9494/97). PRECEDENTE.

'A eficácia erga omnes circunscreve-se aos limites da jurisdição do tribunal competente para julgar o recurso ordinário.'

- Parecer pelo desprovimento do recurso."

Deferida a subida do recurso especial, pela alínea 'a' do permissivo. É o relatório. 


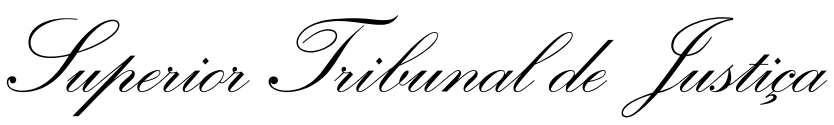

RECURSO ESPECIAL No 411.529 - SP (2002/0014785-9)

\section{VOTO}

\section{A EXMA. SRA. MINISTRA NANCY ANDRIGHI (Relator):}

\section{I - Prequestionamento}

Como bem observado na decisão sobre a admissibilidade do recurso especial proferida na origem, todas as questões legais relevantes para a solução da lide foram expressamente prequestionadas, de forma que não se apresenta, na hipótese dos autos, o óbice das Súmulas 282 e 356, do STF.

\section{II - Mérito}

A questão em discussão diz respeito à interpretação de dois dispositivos legais, a saber, o art. 16 da Lei n ${ }^{0}$ 7.437/85 (Lei da Ação Civil Pública - LAP), com a redação que lhe foi dada pela Lei $n^{0}$ 9.494/97, e 103, III, do Código de Defesa do Consumidor (CDC), aplicável ao procedimento regulado pela LAP por força do que dispõe seu art. 21 (incluído nesta Lei em conformidade com o que dispõe o art. 117 do CDC). As normas controvertidas estão postas em nosso ordenamento com as seguintes palavras:

\section{(LACP)}

Art. 16. A sentença civil fará coisa julgada 'erga omnes', nos limites da competência territorial do órgão prolator, exceto se o pedido for julgado improcedente por insuficiência de provas, hipótese em que qualquer legitimado poderá intentar outra ação com idêntico fundamento, valendo-se de nova prova.

\section{(CDC)}

Art. 103. Nas ações coletivas de que trata este Código, a sentença fará coisa julgada:

(...)

III - 'erga omnes', apenas no caso de procedência do pedido, para beneficiar todas as vítimas e seus sucessores, na hipótese do inciso III do parágrafo único do art. 81. 


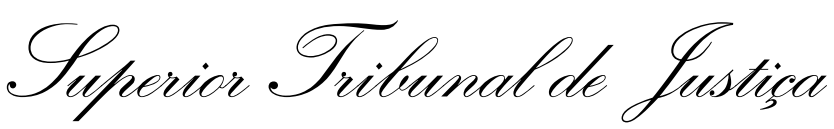

$\mathrm{O}$ art. 81, parágrafo único, inc. III, do $\mathrm{CDC}$, citado na referida norma, regula a defesa coletiva dos direitos, comuns em sua origem, dos quais é titular uma pluralidade de consumidores. É exatamente a hipótese dos autos.

\section{II.1 - A inaplicabilidade do art. 16 da LACP a Direitos Individuais}

\section{Homogêneos}

a) A regulação suplementar, pela $\mathrm{LACP}$, das hipóteses em que há relação de consumo.

A ação civil pública, disciplinada pela Lei $n^{0} 7.347 / 85$, ao menos em sua origem, não se destinava à defesa de direitos individuais homogêneos, mas apenas a interesses difusos ou coletivos. Isso resulta claramente das hipóteses previstas nos incisos I a VI de seu artigo $1^{\circ}$, notadamente da hipótese do inciso IV. Interesses difusos são aqueles de natureza indivisível em que, no pólo ativo, figura uma coletividade indeterminada de indivíduos, ligados entre si por uma circunstância de fato. Direitos coletivos, por sua vez, também indivisíveis, são os de que é titular uma coletividade determinável de indivíduos, ligados entre si ou ao adversário por uma relação jurídica base. O ponto de contato entre uma, e outra modalidade de interesses, é a indivisibilidade de seu objeto. Vale dizer: não é possível satisfazer apenas um dos titulares de nenhuma dessas modalidades de direitos ou interesses. A satisfação de um, implica necessariamente a satisfação de todos.

A intenção original da LACP, de tutelar apenas essas duas modalidades de interesses, determinou toda a arquitetura da lei. Um claro exemplo disso é o destino das indenizações que devem ser pagas pelos eventuais infratores, condenados ao cabo do processo: todo o dinheiro seria revertido, não àqueles que eventualmente seriam titulares dos interesses protegidos, mas a um fundo comum, destinado à reconstrução dos bens lesados (art. $13)$.

Com o advento do Código de Defesa do Consumidor, todavia, duas novidades surgiram: (i) em primeiro lugar, a tutela de qualquer modalidade de direitos do consumidor, 


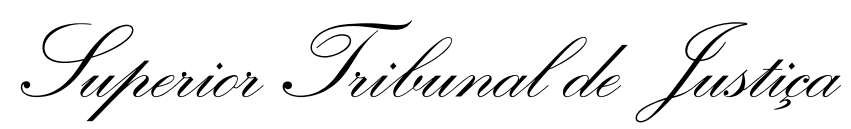

sejam difusos, sejam coletivos, passou a contar com uma regulação específica; (ii) paralelamente, uma nova categoria de direitos passou a ser protegida: a dos interesses ou direitos individuais homogêneos.

Os direitos individuais homogêneos foram definidos pelo inc. III do parágrafo único do art. 81 do $\mathrm{CDC}$, como aqueles "decorrentes de origem comum”. Tais direitos jamais se apresentam indivisíveis, e não são conexos por qualquer relação jurídica que vincule os seus titulares entre si. A sua nota característica é meramente a origem comum do direito, de que é titular individualmente cada membro da coletividade. Disso decorre que, diferentemente do que acontece com relação aos interesses difusos e coletivos, não é possível reparar eventual lesão a um direito individual homogêneo revertendo a indenização a ser paga pelo infrator a um fundo comum. É imprescindível que cada titular do direito lesado receba, individualmente, sua parcela da indenização.

Disso decorreu que, a partir do $\mathrm{CDC}$, a ordem jurídica brasileira passou a contar com uma disciplina específica, independente da disciplina da ação civil pública, para a tutela dos direitos transindividuais dos consumidores em juízo e, dentro dessa disciplina, normas ainda mais especificas regulando a tutela de direitos individuais homogêneos.

O procedimento da ação civil pública, todavia, notadamente no que diz respeito à tutela dos direitos difusos ou coletivos, ainda permanecia aplicável, porém forma subsidiária - ou seja, naquilo que não contrariasse as normas do CDC (art. 90, do CDC). Os direitos individuais homogêneos também passaram a poder ser resguardados mediante esse mecanismo jurídico (art. 21 da LACP), todavia, dadas as suas características específicas, pouco do procedimento estabelecido pela LACP foi utilizado. Uma disciplina própria e praticamente exaustiva foi estabelecida nos arts. 91 a 100 do CDC.

Portanto, de tudo o que foi até aqui exposto resulta que o ordenamento jurídico brasileiro contém: (i) uma disciplina geral, a ser aplicada para a tutela dos interesses relativos ao meio ambiente, bens e direitos de valor artístico, estético e afins, infração à ordem econômica ou urbanística e demais interesses difusos ou coletivos (Lei $n^{\circ} 7.347 / 85$, art. $1^{\circ}$ e seus incisos, excetuado o inciso II); (ii) uma disciplina específica para a tutela de direitos e interesses difusos e coletivos ligados a relações de consumo, cuja regulação se dá pelos arts. 


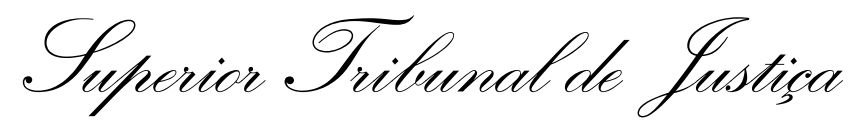

81 a 90 do CDC e, subsidiariamente, pelos dispositivos da LACP; (iii) uma disciplina ainda mais específica, contida nos arts. 91 a 100 do CDC, aplicável somente aos direitos individuais homogêneos.

Diante desse panorama, questiona-se: a norma do art. 16 da LACP, introduzida pela Lei $n^{0}$ 9.494/97, pode ser estendida às ações em que se busca a tutela dos direitos transindividuais protegidos pelo CDC?

A resposta só pode ser negativa. Isso porque, se a LACP somente se aplica às relações de consumo no que não contrariar o $C D C$, ela somente terá incidência nas hipóteses em que este diploma legal seja omisso . Ocorre que o CDC contém, em seu art. 103 e $\S \S$, uma disciplina expressa a respeito da formação da coisa julgada, disciplina essa que não contém qualquer limitação territorial para seu alcance. Assim, o art. 16 da LACP, como norma geral, mesmo tendo sido posteriormente introduzido no ordenamento jurídico, somente se aplicará às hipóteses dos incisos I, III, IV, V e VI do art. $1^{\circ}$ dessa lei. Jamais às hipóteses do inciso II.

b) Entendimento subsidiário: a limitação da eficácia do art. 16 da LACP às hipóteses de direitos difusos e coletivos, em relações de consumo.

Ainda que não se coadune do entendimento ora defendido, e se entenda que, efetivamente, o art. 16 da LACP poderia estender sua eficácia também a hipóteses em que se discutem relação de consumo, tal extensão deveria se limitar aos direitos difusos e aos coletivos, jamais alcançando os direitos individuais homogêneos.

Isso por dois motivos. Em primeiro lugar, porque o escopo da LACP é, como já referido acima, o de tutelar apenas direitos difusos ou coletivos. A tutela a direitos individuais homogêneos foi introduzida originariamente pelo Código de Defesa do Consumidor e é nesse diploma que encontra sua regulação exaustiva.

Em segundo lugar, porque a própria redação do art. 16 da LACP aponta no sentido de que tal norma visa abranger apenas essas duas modalidades de direitos. Com efeito, tanto o art. 16 da LACP, como o art. 103, incs. I e II do CDC, disciplinam da mesma forma 


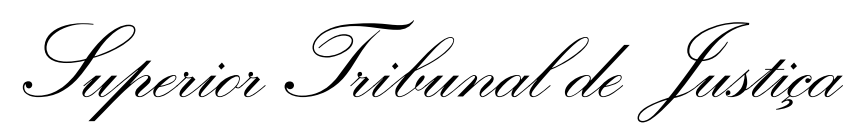

produção da coisa julgada erga omnes, ou seja: mencionam que ela se forma independentemente de a sentença julgar procedente ou improcedente o pedido, e excetuam expressamente a hipótese de improcedência por insuficiência de provas. Ao utilizarem praticamente a mesma redação, tais normas dão uma indicação bastante significativa de estarem regulando as mesmas hipóteses.

A coisa julgada erga omnes que se forma com relação aos direitos individuais homogêneos, todavia, é completamente distinta. Ela, nos expressos termos do inc. III, do art. 103 do CDC, ocorre "apenas no caso de procedência do pedido”, e não há qualquer menção ao julgamento de improcedência por ausência de provas. Também dessa circunstância, portanto, decorre que essa modalidade de direitos é autônoma em relação aos direitos difusos e coletivos.

\section{II.2 - A irrelevância do art. 16 da LACP para limitar a eficácia da sentença, dada a independência de seus efeitos em relação à coisa julgada.}

Novamente formulando um argumento subsidiário, vale ressaltar que, ainda que se entenda que o art. 16 da LACP pode estender sua eficácia também às hipóteses de Ação Civil Pública na qual se busque a tutela coletiva de direitos individuais homogêneos, ainda assim essa norma jamais terá o condão de limitar a eficácia da sentença proferida em tal ação.

Isso porque, ao estabelecer que a sentença "fará coisa julgada nos limites territoriais do órgão prolator", a referida norma acabou por regular apenas e tão somente o fenômeno da coisa julgada, que é absolutamente distinto da eficácia da sentença.

A constatação da independência entre a eficácia da sentença e a eficácia da coisa julgada não é nova, e resta cediça no direito processual civil brasileiro. Sua defesa originária foi feita por ENRICO TULLIO LIEBMAN, para quem a eficácia da sentença consubstanciaria os efeitos modificativos do mundo jurídico promovidos por esse ato judicial, enquanto eficácia da coisa julgada seria meramente a imutabilidade conferida a tais efeitos em decorrência do trânsito em julgado da decisão. Nesse sentido, confiram-se as palavras do 


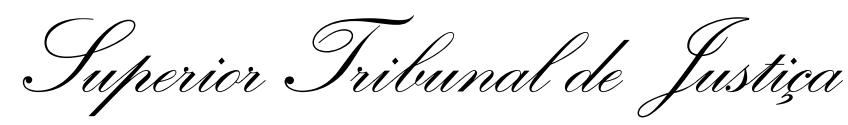

ilustre professor italiano, que tanto influenciou o direito processual civil brasileiro (LIEBMAN, Enrico Tullio, Eficácia e Autoridade da Sentença e outros escritos sobre a coisa julgada, $3^{a}$ Edição, Forense, Rio de Janeiro, 1984, pág. 170):

"I - A declaração oriunda da sentença, assim como seus outros efeitos possiveis, pode conceber-se e produzir-se independentemente da coisa julgada; na aptidão da sentença em produzir os seus efeitos e na efetiva produção deles (quaisquer que sejam, segundo o seu conteúdo) consiste a sua eficácia, e esta se acha subordinada à validade da sentença, isto é, à sua conformidade com a lei.

II - A eficácia da sentença, nos limites de seu objeto, não sofre nenhuma limitação subjetiva; vale em face de todos.

III - A autoridade da coisa julgada não é efeito ulterior e diverso da sentença, mas uma qualidade dos seus efeitos e a todos os seus efeitos referente, isto é, precisamente a sua imutabilidade. Ela está limitada subjetivamente só às partes do processo.

Dessa lição, extraem-se três noções fundamentais: (i) a eficácia da sentença, por ser distinta da eficácia da coisa julgada, se produz independentemente desta; (ii) a eficácia da sentença, desde que não confundida com a figura do trânsito em julgado, não sofre qualquer limitação subjetiva: vale perante todos; (iii) a imutabilidade dessa eficácia, ou seja, a impossibilidade de se questionar a conclusão a que se chegou na sentença, limita-se às partes do processo perante as quais a decisão foi proferida, e só ocorre com o trânsito em julgado da decisão.

Assim, ainda que o objetivo do legislador, ao criar o art. 16 da LACP, fosse o de efetivamente limitar a eficácia da sentença ao território em que seria competente o juiz que a prolatou, esse escopo não foi atingido pela norma da forma como ela restou redigida. Ao dizer que "a sentença civil fará coisa julgada erga omnes, nos limites da competência territorial do órgão prolator", tudo o que o legislador logrou êxito em fazer foi definir que a sentença, em que pese estender seus efeitos a todo o território nacional, não poderá ser questionada em nenhuma demanda futura a ser decidida dentro da base territorial mencionada na lei. Nada mais que isso.

Os efeitos da sentença, portanto, tanto principais (representados pela existência do elemento declaratório característico de toda a decisão judicial) como secundários 


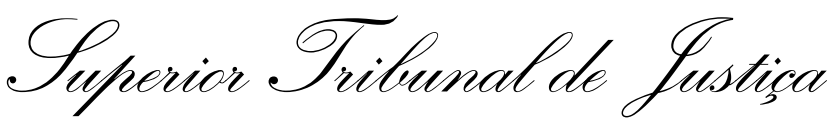

(representados pela criação do título executivo nas ações condenatórias), estendem-se a todos os terceiros que eventualmente se beneficiariam com a decisão.

\section{II.3 - O art. $2^{\circ}$-A, da Lei $n^{0}$ 9.494/97: limitação à substituição processual.}

Não obstante todos os argumentos acima levarem à conclusão de que a limitação que o art. 16 da LACP procurou impor à eficácia de uma sentença não se aplicará à hipótese sub judice, há, ainda, uma derradeira questão que deve ser analisada, de todo independente da anterior, mas fundamental para o correto deslinde da controvérsia.

Trata-se da limitação, imposta pelo art. $2^{\circ}$-A da Lei $n^{0}$ 9.494/97, à substituição processual que só se dá nas ações coletivas. Essa norma dispõe:

"Art. $\mathbf{2}^{\boldsymbol{0}}$-A A sentença civil prolatada em ação de caráter coletivo proposta por entidade associativa, na defesa dos interesses e direitos dos seus associados, abrangerá apenas os substituídos que tenham, na data da propositura da ação, domicílio no âmbito da competência territorial do órgão prolator."

Essa disposição foi introduzida no ordenamento jurídico brasileiro em 24 de agosto de 2001, pela Medida Provisória n 2.180-35. Por esse motivo, ela não foi abordada pelo acórdão recorrido, datado de 20 de fevereiro de 2001, nem pelo Recurso Especial, protocolado em 30 de abril de 2001. Todavia, sendo norma de caráter processual, ela apanha os processos em curso, de forma que cabe a esta Corte sobre ela se manifestar.

Duas características, de plano, saltam aos olhos pela leitura dessa disposição legal: (i) ela não está restrita às ações civis públicas, falando, em vez disso, de ações coletivas ; e (ii) ela regula expressamente hipóteses de substituição processual.

Dessas duas características, duas conseqüências emergem: (i) não se pode opor a essa norma os mesmos argumentos tecidos acima, no sentido de que uma norma relativa à ação civil pública não pode regular relações de consumo (a norma ora analisada se aplica a todos os processos coletivos); (ii) por falar em substituição processual, as ações coletivas de que trata a norma somente podem ser as que discutem direitos individuais homogêneos. 


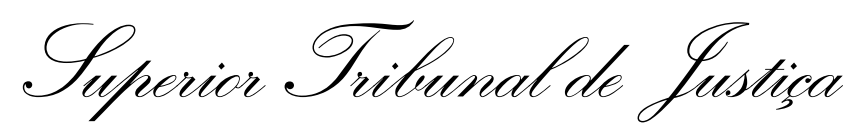

Com efeito, em que pese alguma discussão acerca do caráter ordinário ou extraordinário da representação processual nas ações discutindo direitos difusos ou coletivos, quanto aos direitos individuais homogêneos não há dúvidas: trata-se de substituição processual.

Por outro lado, em que pese falar de substituição processual, a norma dispõe sobre ações coletivas propostas visando a tutela de interesses, não de uma coletividade indeterminada, mas dos associados da instituição autora. Esse trecho da lei indica, de forma paradoxal, que a norma visa a tratar, não de direitos individuais homogêneos, mas direitos coletivos (em sentido estrito), sendo a participação da associação a relação jurídica base necessária para sua caracterização.

De todo modo, essa disposição legal não terá o condão de alterar as conclusões a que se chegou até aqui. Isso porque, ao tratar de ação de caráter coletivo, proposta por entidade associativa, na defesa dos interesses de seus associados, a lei claramente exclui de sua incidência o processo sub judice.

Não obstante o IDEC, autor desta ação, seja uma entidade associativa (o que é revelado pelo fato de seu estatuto admitir a figura de sócios colaboradores ), a presente ação não foi proposta exclusivamente para a defesa dos interesses dos associados dessa entidade. Do pedido inicial extrai-se claramente que a pretensão ora veiculada era de condenação da ré a pagar o valor dos expurgos inflacionários de janeiro de 1989 "a cada um dos titulares de cadernetas de poupança relativo à referida diferença", devendo tal valor "ser fixado em liquidação de sentença (...) a partir da oportuna e necessária comprovação da titularidade da conta-poupança (...)”. Em momento algum o pedido é limitado à tutela de direitos dos associados, o que indica ter sido a demanda proposta em favor de todos os consumidores que, no território nacional, tenham sido lesados. A limitação do art. 2-A, da Lei n ${ }^{\circ}$ 9.494/97, portanto, não se aplica.

Forte em tais razões, dou provimento ao recurso especial para estender a eficácia do acórdão recorrido a todos os consumidores clientes da mesma instituição financeira que se encontrem na situação por ela prevista, no território nacional. 


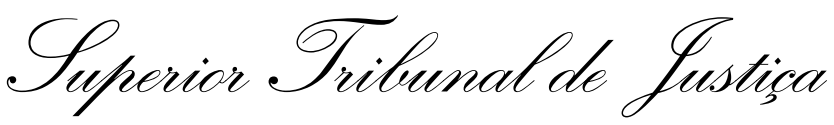

\section{RECURSO ESPECIAL N ${ }^{0} 880.385$ - SP (2006/0124980-2)}

\author{
RELATORA \\ RECORRENTE \\ ADVOGADO \\ RECORRIDO \\ ADVOGADO
}

\author{
: MINISTRA NANCY ANDRIGHI \\ BANCO DE CRÉDITO NACIONAL S/A - BCN \\ : EDUARDO PELLEGRINI DE ARRUDA ALVIM E OUTRO(S) \\ : INSTITUTO BRASILEIRO DE DEFESA DO CONSUMIDOR IDEC \\ DULCE SOARES PONTES LIMA E OUTRO(S)
}

\section{EMENTA}

PROCESSUAL CIVIL. EXECUÇÃO DE SENTENÇA PROFERIDA EM AÇÃO COLETIVA. POSSIBILIDADE DE QUE A EXECUÇÃO DE DIREITOS INDIVIDUAIS HOMOGÊNEOS SEJA PROMOVIDA POR ASSOCIAÇÃO NA QUALIDADE DE REPRESENTANTE DE SEUS ASSOCIADOS. A SENTENÇA CONDENATÓRIA COLETIVA PODE, EM CIRCUNSTÂNCIAS ESPECÍFICAS, SER LIQUIDADA POR CÁLCULOS, PRESCINDINDO-SE DE PRÉVIO PROCEDIMENTO JUDICIAL DE LIQUIDAÇÃO. A PENHORA DEFERIDA CONTRA INSTITUIÇÃO FINANCEIRA PODE RECAIR SOBRE VALORES QUE ESTA TENHA EM CONTA-CORRENTE.

- Na representação a associação age em nome e por conta dos interesses de seus associados, conforme autoriza o art. $5^{\circ}, X X I, C F$, diferentemente do que ocorre na substituição processual.

- Sendo eficaz o título executivo judicial extraído de ação coletiva, nada impede que a associação, que até então figurava na qualidade de substituta processual, passe a atuar, na liquidação e execução, como representante de seus associados, na defesa dos direitos individuais homogêneos a eles assegurados. Viabiliza-se, assim, a satisfação de créditos individuais que, por questões econômicas, simplesmente não ensejam a instauração de custosos processos individuais.

- Diante das circunstâncias específicas do caso, a execução coletiva pode dispensar a prévia liquidação por artigos ou por arbitramento, podendo ser feita por simples cálculos, na forma da antiga redação do art. 604, CPC.

- A jurisprudência desta Corte, além de repelir a nomeação de títulos da dívida pública à penhora, admite a constrição de dinheiro em execução contra instituição financeira. Precedentes.

Recurso não conhecido.

\section{ACÓRDÃo}

Vistos, relatados e discutidos estes autos, acordam os Ministros da TERCEIRA TURMA do Superior Tribunal de Justiça, na conformidade dos votos e das notas taquigráficas constantes dos autos, por unanimidade, não conhecer do recurso especial, nos termos do voto da Sra. Ministra Relatora. Os Srs. Ministros Sidnei Beneti e Ari Pargendler votaram com a Sra. Ministra Relatora. Impedido o Sr. Ministro Massami Uyeda. 


\title{
Suporior Tribunal de fustica
}

Brasília (DF), 02 de setembro de 2008.(data do julgamento).

\author{
MINISTRA NANCY ANDRIGHI \\ Relatora
}

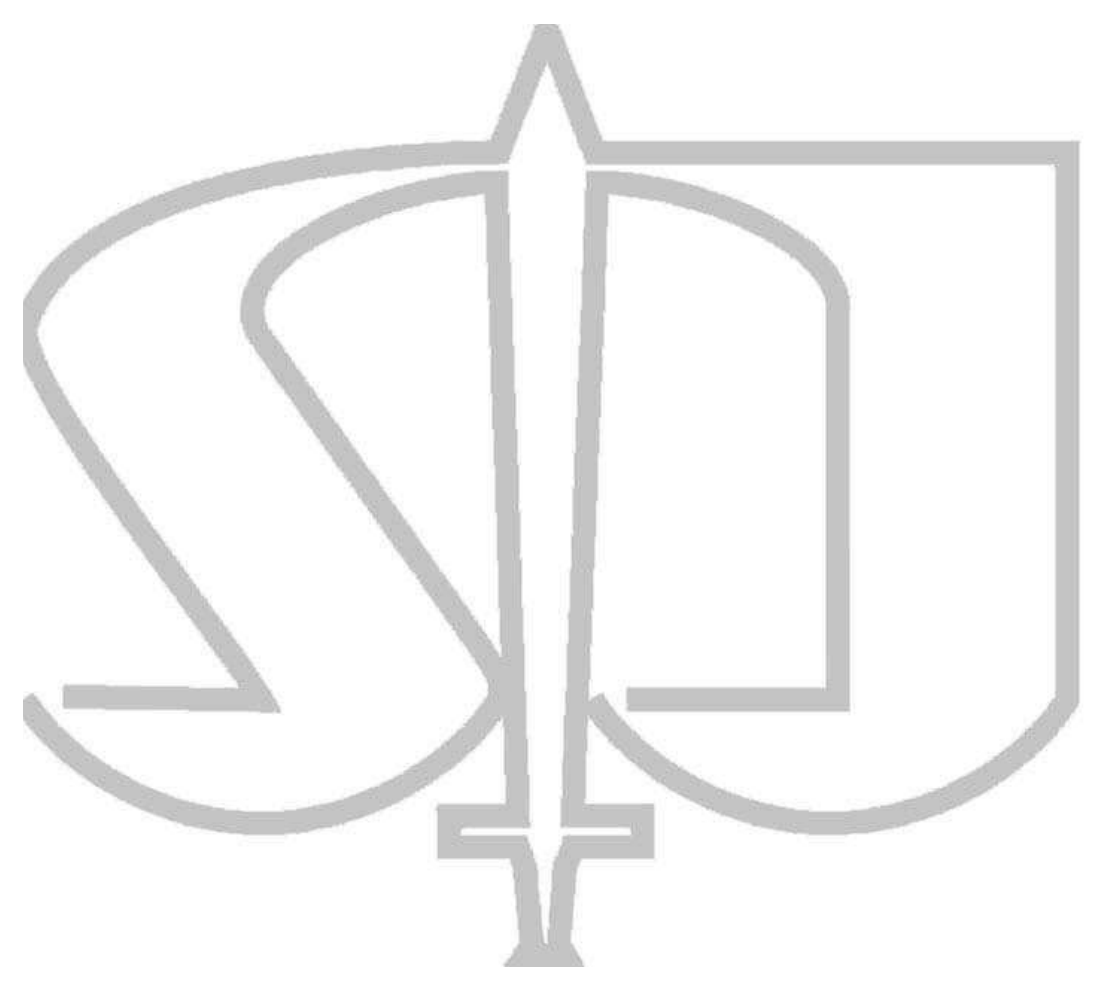




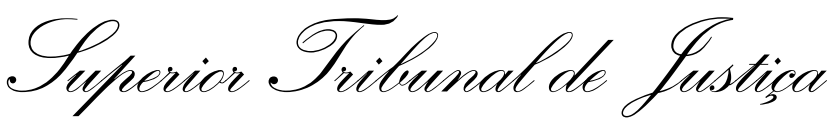

\section{RECURSO ESPECIAL N ${ }^{0} 880.385$ - SP (2006/0124980-2)}

$\begin{array}{ll}\text { RECORRENTE } & : \text { BANCO DE CRÉDITO NACIONAL S/A - BCN } \\ \text { ADVOGADO } & : \text { EDUARDO PELLEGRINI DE ARRUDA ALVIM E OUTRO(S) } \\ \text { RECORRIDO } & : \text { INSTITUTO BRASILEIRO DE DEFESA DO CONSUMIDOR IDEC } \\ \text { ADVOGADO } & : \text { DULCE SOARES PONTES LIMA E OUTRO(S) }\end{array}$

\section{RELATÓRIO}

\section{A EXMA. SRA. MINISTRA NANCY ANDRIGHI (Relator):}

Cuida-se de recurso especial interposto por BCN - Banco de Crédito Nacional S.A., com fundamento no arts. 105, inciso III, alíneas "a" e "c" da Constituição Federal, contra acórdão proferido pelo extinto Primeiro Tribunal de Alçada Cível do Estado de São Paulo.

Ação: Trata-se de execução provisória proposta pelo IDEC - Instituto Brasileiro de Defesa do Consumidor em face do recorrente. Pretende-se a execução de acórdão proferido pelo extinto Primeiro Tribunal de Alçada Cível de São Paulo e que condenou o recorrente a pagar aos associados do IDEC o índice de $42,72 \%$ para a correção de valores depositados em caderneta de poupança no mês de janeiro de 1999. O IDEC afirma que seus associados seriam titulares de um crédito total de $\mathrm{R} \$ 815.562,92$.

Decisão: Após a nomeação à penhora de 443 letras financeiras do tesouro (LFTs), fato impugnado pelo IDEC, o juízo em primeiro grau de jurisdição determinou o bloqueio, em dinheiro, de valores que se encontrassem à disposição do recorrente.

Acórdão: $\mathrm{O}$ Tribunal de origem negou provimento ao agravo de instrumento interposto pelo recorrente. Confira-se:

"Ação civil pública promovida pelo IDEC para a cobrança da diferença entre a inflação apurada no mês de janeiro de 89 e o indice creditado nas contas ou depósitos em poupança no mês subseqüente. Procedência. Execução provisória, eis que pendentes de julgamento recursos às Cortes Superiores para se definir os limites subjetivos da coisa julgada, se circunscrita à Capital de S. Paulo, nos limites da jurisdição do magistrado que proferiu a sentença ou erga omnes. Este tribunal decidiu que valeria erga omnes. Legitimidade do IDEC para a execução (Lei 8.078/90, arts. 97, 98 e 100). Execução que está sendo levada a efeito em proveito de 115 associados do IDEC, cujos extratos foram exibidos, com os respectivos cálculos. Desnecessidade de prévia liquidação dos valores devidos. Execução que 


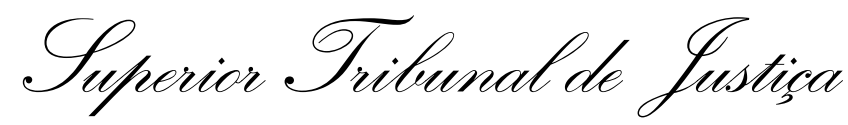

depende apenas de cálculos aritiméticos, elaborados e exibidos pelos poupadores (CPC, art. 604). Penhora que deve recair sobre numerário do banco. Instituição que revela expressivo lucro anual, sem que possa negar a existência de dinheiro em caixa. Penhora resgatáveis apenas em 2006, quando o juiz tem de dar rápida solução ao litígio que se arrasta desde 1994 (CPC, arts. 125, II e 620). Penhora do dinheiro mantida. Recurso não provido".

Embargos de Declaração: Opostos pelo recorrente e rejeitados pelo Tribunal de origem.

Recurso Especial: Sustentou haver negativa de vigência aos seguintes dispositivos da legislação federal: (i) arts. $81,82,83,97,98$, e 100, CDC, assim como art. 267, $\S 3^{\circ}, \mathrm{CPC}$, diante da ilegitimidade ativa; (ii) arts. 13, Lei 7.347/85, 125, 535, 604, 618, 620, 648, 655, CPC, 68, Lei 9.069, e $6^{\circ}$, Lei Complementar 105/00. Afirmou haver dissídio pretoriano.

Recurso Extraordinário: Interposto pelo recorrente a fls. 1.554 e seguintes.

Juízo Prévio de Admissibilidade: Apresentadas contra-razões (fls. 1.591/1613), o Tribunal de origem negou provimento ao Especial. Dei provimento ao agravo de instrumento, para melhor análise do Especial, determinando a subida dos autos ao STJ.

Parecer do Ministério Público Federal: O Procurador da República, Aurélio Virgílio Veiga rios, opinou pelo não provimento do recurso.

É o relatório. 


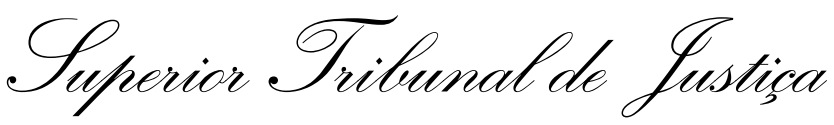

\section{RECURSO ESPECIAL N ${ }^{\circ} 880.385$ - SP (2006/0124980-2)}

$\begin{array}{ll}\text { RELATORA } & : \text { MINISTRA NANCY ANDRIGHI } \\ \text { RECORRENTE } & : \text { BANCO DE CRÉDITO NACIONAL S/A - BCN } \\ \text { ADVOGADO } & : \text { EDUARDO PELLEGRINI DE ARRUDA ALVIM E OUTRO(S) } \\ \text { RECORRIDO } & : \text { INSTITUTO BRASILEIRO DE DEFESA DO CONSUMIDOR IDEC } \\ \text { ADVOGADO } & : \text { DULCE SOARES PONTES LIMA E OUTRO(S) }\end{array}$

\section{VOTO}

\section{A EXMA. SRA. MINISTRA NANCY ANDRIGHI (Relator):}

Cinge-se a controvérsia a examinar a legalidade da execução coletiva promovida por associação de consumidores e do bloqueio de valores em contas correntes da instituição financeira recorrente.

\section{Violação ao art. 535, CPC.}

Da análise do acórdão recorrido, infere-se que o Tribunal a quo de fato enfrentou os pontos suscitados pelo recorrente como omissos, tanto que integram o objeto do próprio recurso especial e serão enfrentados logo adiante. Não há que se falar, assim, em violação ao art. 535, CPC.

\section{Legitimidade Ativa.}

O Tribunal de origem afirmou a legitimidade ativa da associação exeqüente nos seguintes termos:

"Nos termos do art. 100 da Lei 8078/90 (CDC), decorrido o prazo de um ano sem habilitação de interessados em número compativel com a gravidade do dano, poderão os legitimados do art. 82 promover a liquidação e execução da indenização devida. Acrescenta o parágrafo único que o produto da indenização devida reverterá para o fundo criado pela Lei 7.347, de 24.6.85. No caso, entretanto, não se trata de indenização, mas de cobrança de valores indevidamente sonegados pelo Banco o IDEC promove a execução no interesse de 115 de seus associados. Cada um deles, a partir das fls. 1116, apresentou documento indicando o número e agência da respectiva conta, o valor em depósito em janeiro de 89 e a diferença reclamada. Esclarece o art. 100 do CDC que as pessoas indicadas no art. 82 só poderiam propor a ação 


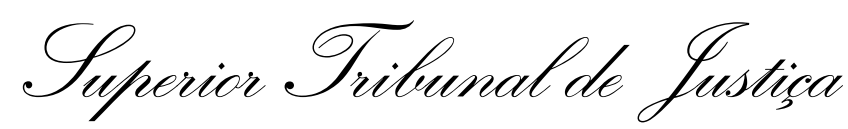

de execução em favor do fundo se não fosse proposta a ação de execução pelos interessados, beneficiários da condenação. Não se trata de execução em favor do fundo, mas em proveito dos poupadores lesados pelo Banco. A legitimidade do IDEC decorre, ainda, do disposto nos arts. 82, 83, 97 e 98 do CDC”.

O recorrente sustentou, então, que a associação de consumidores não detém legitimidade ativa para iniciar a execução coletiva, havendo, assim, violação aos arts. 81, 82, 83, 97, 98, e 100, CDC, assim como art. 267, §3º, CPC, e art. 13, LACP. Na visão do recorrente, a legitimidade extraordinária, atribuída às associações para o ajuizamento de ações coletivas (ou civis públicas), não se estende à execução de tais julgados. A execução, em seu entender, deverá ser feita individualmente, por cada um daqueles que foram beneficiados com a decisão judicial. Somente após o decurso de um ano após o trânsito em julgado ou após a sentença de liquidação, seria possível a execução coletiva. Ademais, a execução coletiva haveria de destinar seu produto ao fundo fluido de que trata o art. 13, Lei 7.347/85.

O Recurso Especial não versa, portanto, sobre a legitimidade da associação autora para o ajuizamento da ação de conhecimento, mas apenas para a execução do julgado. Não se discute, ainda, a abrangência territorial do título executivo. Trata-se apenas de examinar se a associação autora pode representar seus associados no processo de execução.

Delimitada a questão, sua solução, necessariamente, passa pela correta interpretação do art. 97, CDC.

É razoável afirmar que os interesses difusos e coletivos não se individualizam jamais, pois a indivisibilidade é de sua essência, e, por isso, submetem-se sempre a uma execução coletiva. Não havendo outros legitimados, só aquelas entidades indicadas no art. 82, CDC, podem, efetivamente, iniciar o processo de liquidação e execução.

Note-se, entretanto, que os interesses individuais homogêneos, como o próprio nome indica, são individuais e divisíveis por natureza, recebendo tratamento processual coletivo por questões de política judiciária. Sendo assim, as vítimas detêm inegável legitimidade ativa para liquidar e executar aquilo que lhes foi assegurado por sentença caso tal conduta lhe convenha.

Extremadas essas duas situações, restaria saber se as entidades indicadas no art. 82 podem exercer algum papel na execução de uma sentença que tenha reconhecido a existência 


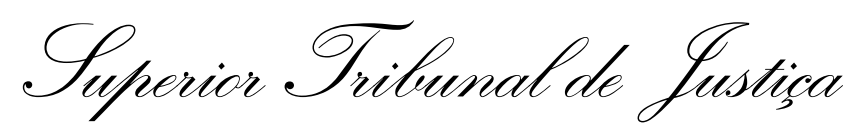

de direitos individuais homogêneos.

Em que pese alguma dificuldade inicial, fato natural dado o caráter inovador da tutela coletiva, não há hoje dúvida sobre a conclusão de que a legitimidade ativa das associações para a propositura de ações coletivas, latu sensu, assenta-se sobre dois institutos diversos: a substituição processual e a representação processual.

Diferentemente do que ocorre na substituição, na representação a associação não atua em nome próprio, mas, ao contrário, age em nome e por conta dos interesses de seus associados. Note-se que o STF vem reconhecendo que a atuação por representação encontra amparo na própria Constituição Federal (art. 5, XXI) (conf. RMS 21.514, Rel. Min. Marco Aurélio, DJ 18.6.93).

Assim, se a atuação da associação no processo de cognição pauta-se pela substituição, nada impede que ela passe a atuar, na liquidação e execução, como representante. O universo de representados pode ser menor que o de substituídos, mas mesmo assim a solução atende à necessidade de que a proteção jurisdicional se torne concreta.

Com efeito, após a sentença, pode-se constatar que o valor ínfimo dos valores atribuídos a cada vítima não justifica o ônus econômico que envolve o processo de liquidação e execução. Por isso, de forma consentânea com as diretrizes que orientam o processo coletivo, deve-se admitir a execução coletiva, com base na representação processual, como a única forma idônea de pulverizar o custo do processo, autorizando a satisfação dos direitos individuais reconhecidos por sentença.

No processo sob julgamento, o pedido de execução envolve um total de $\mathrm{R} \$ 815.562,92$, mas, entre as pessoas representadas pelo exeqüente, há algumas que detêm contas com crédito inferior a $\mathrm{R} \$ 100,00$. Exigir a liquidação e execução individual pode, portanto, representar uma pá-de-cal sobre as conquistas que o processo coletivo representam.

A lição de Ada Pellegrini Grinover corrobora tal entendimento ao reconhecer que "o caso surge como de representação, devendo os entes e pessoas enumeradas no art. 82 agirem em nome das vítimas ou sucessores" (Vv. Aa. Código Brasileiro de Defesa do Consumidor: Comentado pelos autores do Anteprojeto. Rio de Janeiro: Forense Universitária, 2001, p. 817). 


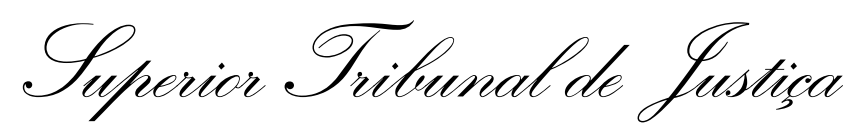

Nesta linha, não se sustenta o argumento exposto no Recurso Especial segundo o qual a execução coletiva só seria possível nos termos do art. 100, CDC, ou seja, após decorrido o prazo de um ano sem habilitação de credores interessados e desde que o produto da indenização se destine ao fundo fluido de que trata o art. 13, LACP. Não há dúvida que essa visão ignora o mandamento constitucional segundo o qual as associações podem agir como representantes processuais de seus associados.

Observo, por fim, que o recorrente pretende demonstrar que os correntistas em questão não outorgaram à recorrida qualquer autorização específica. Essa é, no entanto, uma discussão que exige o reexame de provas e que, por isso, é vedada ao STJ por força de sua Súmula 7.

\section{Necessidade de Liquidação da Sentença.}

O Tribunal de origem considerou desnecessária a liquidação por artigos e por arbitramento. Entendeu-se que a determinação do valor da condenação dependeria apenas de cálculo aritmético e, nos termos do art. 604, CPC, não teria havido qualquer ilegalidade na execução iniciada pelo IDEC.

O recorrente vem sustentando, entretanto, que a execução não poderia ter sido deflagrada sem que houvesse prévia liquidação individual em que cada indivíduo prove sua condição de vítima. O Recurso Especial aventou, então, a violação aos arts. 3º 604, 618, I, CPC, bem como aos arts. 95, 97, 98, 99 e 100, CDC.

A leitura atenta do art. 98, CDC, revela que a sentença proferida em ação coletiva sempre é ilíquida. Todavia, o CDC não determinou um procedimento específico de liquidação. Assim, na lei, nada há que impeça a liquidação por simples cálculos.

Se é certo que muitas sentenças coletivas exigem processo de liquidação em que se prove a condição de vítima, como é o caso de acidentes ambientais, há outras hipóteses em que o procedimento prévio de liquidação revela-se desnecessário, como se verifica no processo sob julgamento.

Os representados pelo IDEC nesta execução apresentaram documentos que indicam o número e agência da respectiva conta, bem como o valor em depósito em janeiro de 


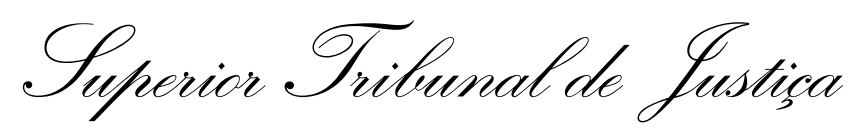

89. Daí, para que se chegue ao valor devido basta uma simples operação matemática com planilha de cálculo. Certamente, a situação poderá ser diversa se outros beneficiados pela sentença não puderem comprovar sua condição de vítima com extratos ou documentos. Diante da diversidade de situações fáticas postas no processo coletivo, não se pode ler a lei de forma restritiva, como se ela estivesse a exigir sempre a liquidação por artigos.

Ressalte-se que o recorrente não sofrerá prejuízo processual com o procedimento aceito pelo Tribunal de origem, pois poderá, em sede de embargos do devedor, argüir a defesa que entender necessária.

Desta forma, o acórdão recorrido não violou a legislação federal ao aceitar a aplicação à hipótese do art. 604, CPC, então vigente.

\section{Arts. 125, II, 620 e 655, CPC.}

O Recurso Especial impugna, ainda, o bloqueio de valores em conta-corrente, insistindo na nomeação à penhora de Letras Financeiras do Tesouro.

Observe-se, entretanto, que o STJ em diversas oportunidades enfrentou a questão da nomeação à penhora de Letras Financeiras do Tesouro, concluindo ser justa a recusa do credor em aceitá-las. (Conf. AgRg no REsp 904.528/RS, Primeira Turma, Rel. Min. Francisco Falcão, DJ 12.04.2007; REsp 860.411/SP, Primeira Turma, Rel. Min. Luiz Fux, DJ 08.11.2007). Nesse mesmo sentido, esta Terceira Turma asseverou que "a jurisprudência desta Corte, além de repelir a nomeação de títulos da dívida pública à penhora, admite a constituição [sic] de dinheiro depositado em instituição financeira” (AgRg no Ag 709.528/ES, Rel. Min. Menezes Direito, DJ 22.05.2006).

O processo de execução passou a ser pautado por um novo paradigma, segundo o qual a rápida consecução do resultado assegurado pelo direito material é a tônica que impregna os atos processuais. Justamente por isto, não há que se falar em violação ao art. 620, CPC, pelo simples fato de haver a penhora sobre dinheiro.

Ir além deste exame certamente exigiria o reexame de fatos e provas, pois só assim se poderia infirmar a conclusão do acórdão recorrido. Com efeito, "o entendimento pacífico da 3. ${ }^{a}$ e 4. ${ }^{a}$ Turmas do STJ é que a verificação dos motivos que justificaram a rejeição dos 


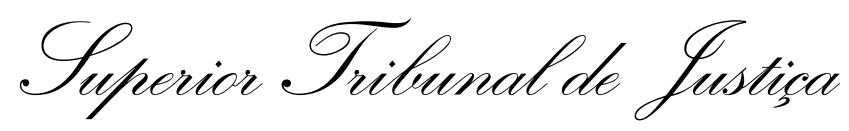

bens oferecidos à penhora demandam, necessariamente, o revolvimento do acervo fático-probatório dos autos, procedimento vedado nos termos da Súmula 7 do STJ" (AgRg no Ag 777.351/SP, Terceira Turma, minha relatoria, DJ 27.11.2006; no mesmo sentido, AgRg no Ag 748.470/RJ, Quarta Turma, Rel. Min. Jorge Scartezzini, DJ 11.09.2006).

Forte em tais razões, NÃO CONHEÇO do Recurso Especial.

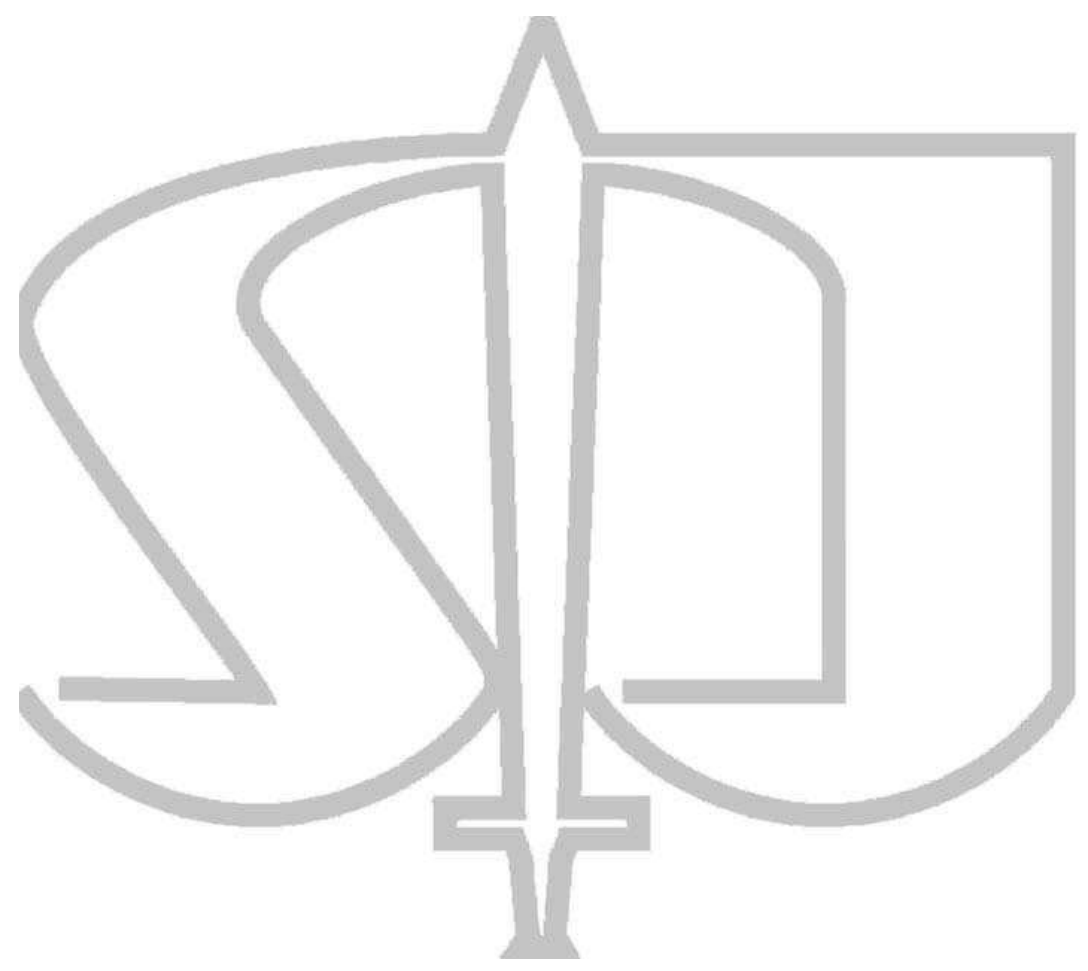

